DOE/EIA-0064(98)

Distribution Category UC-950

\title{
Coal Data: A Reference
}

\author{
February 1995
}

Energy Information Adminlstration

Office of Coal, Nuclear, Elaciric and Altemate Fuels

U.S. Department of Energy

Washington, DC 20585

Thls report was prepared by the Energy kiomation Administration, the independent statistical and anesyltal agency within the Department of Energy. The infomation contained herein should not be consusued as advocating or reflecting any policy posltion of the Department of Energy or of any other organization. 


\section{Contacts}

This report was prepared in the Supply Anatysis Branch, Analysis and Systems Division, Office of Coal, Nuclear, Electric and Altenate Fuels. General information regarding this publication may be obtained from John Geidl, Director, Office of Coal, Nuclear, Electric and Altemate Fuels $(202 / 254-5570)$; Robert M.
Schnapp, Director, Analysis and Systems Division (202/254-5392); Betsy OBrien, Chiel, Supply Analysis Branch; or B. D. Hong (202/254-5365). Specific questions should be addressed to Eugene R. Slatick, (202254-5384). Questions on current coal and other energy statistics should be directed to NEtC (202/586-9800). 


\section{DISCLAMMER}

This report was.preparad as an account of work sponsored by an agency of the United States Government. Neither the United States Government nor any agency thereof, nor any of their employees, make any warrenty, express or Implled, or assumes any legal liability or responsibility for the accuracy, completeness, or usefulness of any information, apparatus, product, or process disciosed, or represents that its use would not infringe privately owned rights. Reference herein to any specific commercial product, process, or service by trade name, trademark, menufacturer, or otherwise does not necessarily constitute or Imply its endorsement, recommendation, or favoring by the United States Government or any agency thereof. The views and opinions of authors expressed herein do not necessarlly state or reflect those of the United States Government or any agency thereof. 


\section{DISCLAIMER}

Portions of this document may be illegible in electronic image products. Images are produced from the best available original document. 


\section{Preface}

Section 205(a)(2) of the Deparment of Energy Organization Act of 1977 (Public Law 95-91) requires the Administrator of the Energy Information Administration (EIA) to carry out a central, comprehersive, and unified energy data and information program that will collect, evaluate, assemble, analyze, and disseminate data and information relevint to energy resources, reserves, and related economic and statistical irformation.

The legislation that created EIA vested the organization wtth an element of statutory independence. EIA does not take positions on policy questions. EIA's responsibility is to provide timely, high-quality information and to perform objective, credible analyses.

As part of EIA's program to provide information on coal, this report, Coal Datat $A$ Reference, summarizes basic information on the mining and use of coal, an important source of energy in the United States. This report is written for a general audience. The goal is to cover basic material and strike a reasonable compromise between overly generalized statements and detailed analyses. The section "Supplemental Figures and Tables" contains statisties, graphs, maps, and other illustrations that show trends, patterns, geographir locations, and similar coal-related information. The section "Coal Terminology and Related Information" provides additional information about terms mentioned in the text and introduces some new terms.

The last edition of Coal Data: $A$ Refference was published in 1991. The present edition contains updated data as well as expranded reviews and additional information. Added to the text are discussions of conl quality, conl prices, unions, and strikes. The appendix has been expanded to provide statistics on a variety of additional topics, such as: trends in coal production and royalties from Federal and Indian coal leases, hours worked and earnings for coal mine employment, railroad coal shipments and revenues, waterborne coal traffic, coal export loading terminals, utility coal combustion byproducts, and trace elements in cosl.

The information in this report has been gleaned mainly from the sources in the bibliography. The reader interested in going beyond the scope of this report should consult these sources. The statistics are largely from reports published by the Energy Information Administration. 



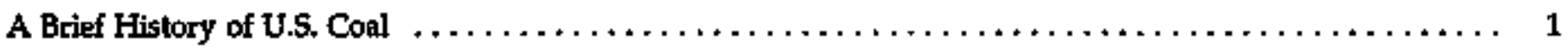

United States Coal: An Overview $\ldots \ldots \ldots \ldots \ldots \ldots \ldots \ldots \ldots \ldots \ldots \ldots \ldots \ldots \ldots \ldots \ldots \ldots \ldots \ldots, \ldots \ldots \ldots$

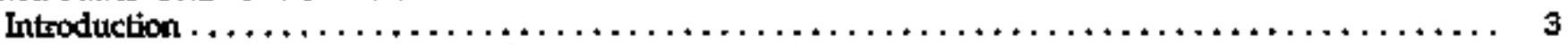

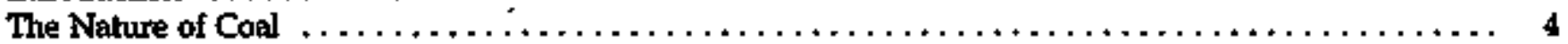

U. Coal Deposits $\ldots \ldots \ldots \ldots \ldots \ldots \ldots \ldots \ldots \ldots \ldots \ldots \ldots \ldots \ldots \ldots \ldots \ldots \ldots \ldots \ldots \ldots \ldots \ldots$

Resources and Reserves $\ldots \ldots \ldots \ldots \ldots \ldots \ldots \ldots \ldots \ldots \ldots \ldots \ldots \ldots \ldots \ldots \ldots \ldots \ldots \ldots \ldots \ldots \ldots \ldots, 8$

Mining $\ldots \ldots \ldots \ldots \ldots \ldots \ldots \ldots \ldots \ldots \ldots \ldots \ldots \ldots \ldots \ldots \ldots \ldots \ldots \ldots \ldots \ldots \ldots \ldots \ldots \ldots \ldots \ldots \ldots \ldots 10$

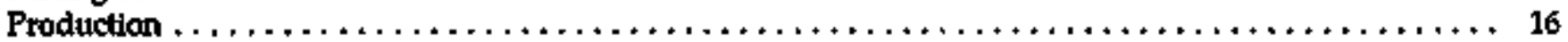

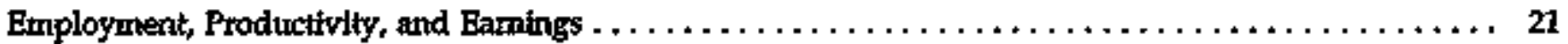

Health and Safety $\ldots \ldots \ldots \ldots \ldots \ldots \ldots \ldots \ldots \ldots \ldots \ldots \ldots \ldots \ldots \ldots \ldots \ldots \ldots \ldots \ldots \ldots, 23$

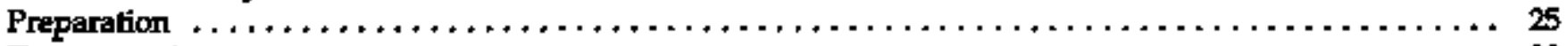

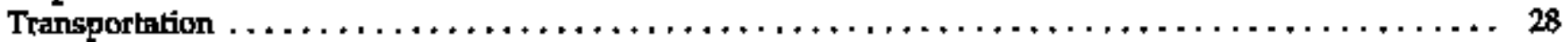

Supply and Stocks $\ldots \ldots \ldots \ldots \ldots \ldots \ldots \ldots \ldots \ldots \ldots \ldots \ldots \ldots \ldots \ldots \ldots \ldots \ldots \ldots \ldots \ldots \ldots \ldots \ldots \ldots, \ldots$

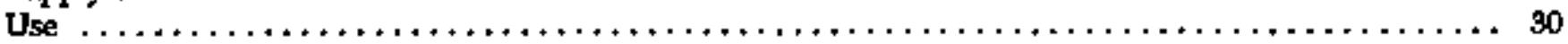

Coal and Coke Trade $\ldots \ldots \ldots \ldots \ldots \ldots \ldots \ldots \ldots \ldots \ldots \ldots \ldots \ldots \ldots \ldots \ldots \ldots \ldots \ldots \ldots \ldots, 36$

Coal and the Environment $\ldots \ldots \ldots \ldots \ldots \ldots \ldots \ldots \ldots \ldots \ldots \ldots \ldots \ldots \ldots \ldots \ldots \ldots \ldots \ldots \ldots \ldots \ldots \ldots 37$

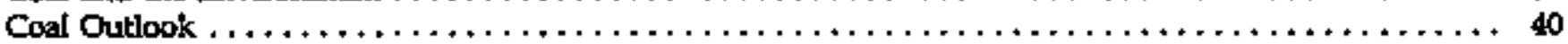

Supplemental Figures and Tables $\ldots \ldots \ldots \ldots \ldots \ldots \ldots \ldots \ldots \ldots \ldots \ldots \ldots \ldots \ldots \ldots \ldots \ldots \ldots \ldots$

Coal Terminology and Related Information $\ldots \ldots \ldots \ldots \ldots \ldots \ldots \ldots \ldots \ldots \ldots \ldots \ldots \ldots \ldots \ldots \ldots \ldots$

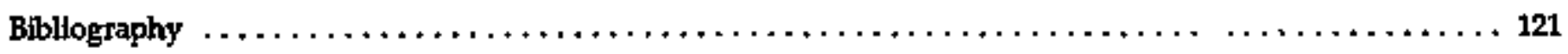

Sources of Information on Coal $\ldots \ldots \ldots \ldots \ldots \ldots \ldots \ldots \ldots \ldots \ldots \ldots \ldots \ldots \ldots \ldots \ldots \ldots \ldots \ldots$ 
1. U.S. Coel Production from the 10 Leadtrig Coalbeds, $1993 \ldots \ldots \ldots \ldots \ldots \ldots \ldots \ldots \ldots \ldots \ldots \ldots \ldots$

2. The I0 Leading U.S. Coal-Producing States, $1993 \ldots \ldots \ldots \ldots \ldots \ldots \ldots \ldots \ldots \ldots \ldots \ldots \ldots \ldots \ldots \ldots \ldots$

3. Peak Year of US. Coal Production by State, Through $1993 \ldots \ldots \ldots \ldots \ldots \ldots \ldots \ldots \ldots \ldots \ldots \ldots \ldots$

4. Cumulative Coal Production by State, $1890-1993 \ldots \ldots \ldots \ldots \ldots \ldots \ldots \ldots \ldots \ldots \ldots \ldots \ldots \ldots \ldots$

5. The I0 Leading U.S. Coal-Producing Comparies, $1993 \ldots \ldots \ldots \ldots \ldots \ldots \ldots \ldots \ldots \ldots \ldots \ldots \ldots 20$

6. The 10 Leading States in U.S. Coal Mire Employment, $1993 \ldots \ldots \ldots \ldots \ldots \ldots \ldots \ldots \ldots \ldots \ldots \ldots$

7. The 10 Leading U.S. Coal-Consuming States, $1993 \ldots \ldots \ldots \ldots \ldots \ldots \ldots \ldots \ldots \ldots \ldots \ldots \ldots$

8. U.S. Demonstrated Reserve Base of Coal by Potential Mining Method and Ranked by State Total,

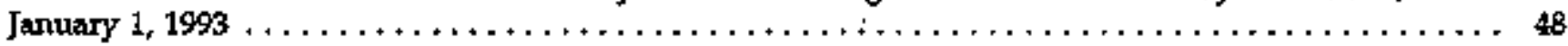

9. Estinates of U.S. Recoverable Coal Reserves by Btu/Sulfur Content and Region, $1992 \ldots \ldots \ldots \ldots \ldots$. . . . .

10. U.S. Coal Production and Related Statistics, Selected Years, 1980, 1985, 1990-1993 . . . . . . . . . . . 54

11. U.S. Coal Production by Coal-Producing Region and State, Selected Years, 1970, 1980, 1990-1993 . . . . 57

12. Totas U.S. Coal Froduction and Number of Mines by State and Type of Mining 1993 . . . . . . . . . 58

13. U.S. Underground Coal Production by Coal-Producing Region, State, and Coalbed Thickness, 1993 . . . 60

14. U.S. Surface Coal Production by Coal-Producing Region, State, and Coalbed Thtikness, $1993 \ldots \ldots$

15. U.S. Coal Production by Coal-Producing Region, State, and Coalbed Thickness, $1993 \ldots \ldots \ldots \ldots .62$

16. Production (Sales Volume) from Federal and Indian Coal Lands Compared with Production from Other Sources and Coel Royalties, Selected Years, 1970, $1975,1980-1993 \ldots \ldots \ldots \ldots \ldots \ldots \ldots \ldots$

17. U.S. Coal Mining Acreage, Production (Sales Volume) and Royalties tron Federal and Indian Leases

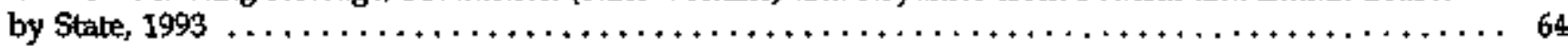

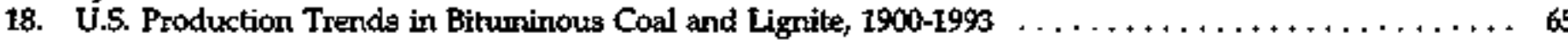

19. Production Trends in Perunsylvania Anthracite, $1900-1993 \ldots \ldots \ldots \ldots \ldots \ldots \ldots \ldots \ldots \ldots \ldots \ldots \ldots$. $\ldots \ldots$. $\ldots \ldots$

20. U.S. Labor Productivity in Coal Mining, $1949-1993 \ldots \ldots \ldots \ldots \ldots \ldots \ldots \ldots \ldots \ldots \ldots \ldots \ldots \ldots \ldots \ldots+\ldots 9$

21. Profile of U.S. Coal Miners, $1986 \ldots \ldots \ldots \ldots \ldots \ldots \ldots \ldots \ldots \ldots \ldots \ldots \ldots \ldots \ldots \ldots \ldots \ldots \ldots+70$

22. US, Coal Mining Average Employment, Hours Worked, and Earnings, Selected Years,

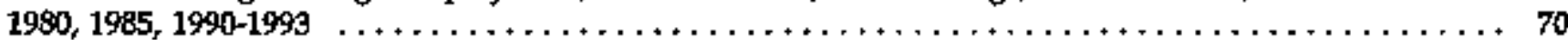

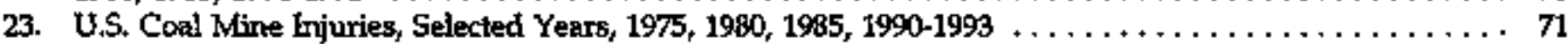

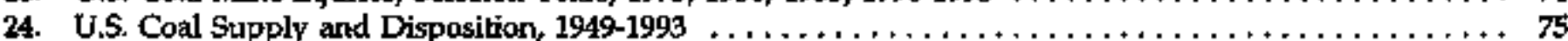

25. Year-End Stocks of U.S. Coal by End-Use Sector, $1949-1993 \ldots \ldots \ldots \ldots \ldots \ldots \ldots \ldots \ldots \ldots \ldots \ldots, 77$

26. U.S. Coke Supply and Dispostition, $1949-1993 \ldots \ldots \ldots \ldots \ldots \ldots \ldots \ldots \ldots \ldots \ldots \ldots \ldots \ldots \ldots \ldots$

27. U.S. Coal Consumption by End-Use Sector, $1949-1993 \ldots \ldots \ldots \ldots \ldots \ldots \ldots \ldots \ldots \ldots \ldots \ldots \ldots$

28. U.S. Coal Consumption by Censtus Divtsion and State, $1989-1993 \ldots \ldots \ldots \ldots \ldots \ldots \ldots \ldots \ldots \ldots .81$

29. U.S. Coal Consumption by End-Use Sector and by Census Division and State, I993 . . . . . . . . 82

30. U.S. Coal Prices, 1949-1993 $\ldots \ldots \ldots \ldots \ldots \ldots \ldots \ldots \ldots \ldots \ldots \ldots \ldots \ldots \ldots \ldots \ldots \ldots \ldots$

31. Average Mine Proce of U.S. Coal by Mining Method, $1980-1993 \ldots \ldots \ldots \ldots \ldots \ldots \ldots \ldots \ldots \ldots$. 86

32. Average Mine Price of U.S. Coal by Rank, $1980-1993 \ldots \ldots \ldots \ldots \ldots \ldots \ldots \ldots \ldots \ldots \ldots \ldots$

33. Average Mine Prtice of U.S. Coal by State and Mining Method, $1993 \ldots \ldots \ldots \ldots \ldots \ldots \ldots \ldots \ldots 8$

34. Foretgn Direct Investment in U.S. Coal, and Share of Total U.S. Coal Production, 1980-1992 . . . . . 87

35. U.S. Coal Mining Cost Comparisons by Mining Methods $\ldots \ldots \ldots \ldots \ldots \ldots \ldots \ldots \ldots \ldots \ldots \ldots$ 88

36. Quality and Cost of Coal Receipts of U.S. Electric Uttlittes of 50 Megawatts or Larger Naneplate

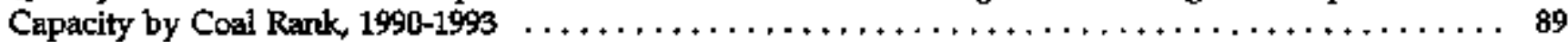

37. Cost of Contract and Spot Coal Receipts at U.S. Electric Utilities of 50 Megawatts of Larger

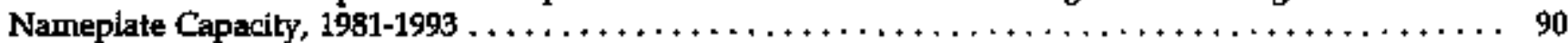

38. U.S. Coal Receipts and Price by Sulfur Content at Electric Utility Plants, by State of

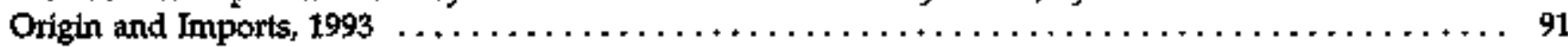

39. U.S. Electriclty Generation by Energy Source, Seiected Years, 1980, 1985, 1990-1993 . . . . . . . . . 91

40. Major U.S. Coal-Carrylng Railroad Systems, $1993 \ldots \ldots \ldots \ldots \ldots \ldots \ldots \ldots \ldots \ldots \ldots \ldots \ldots \ldots \ldots \ldots \ldots$. 92

41. U.S. Ratl Transportation of Coal, $1980-1993 \ldots \ldots \ldots \ldots \ldots \ldots \ldots \ldots \ldots \ldots \ldots \ldots \ldots \ldots \ldots \ldots \ldots$

42. Coal Handled and Revenue Received by Major U.S. Coal-Canying Railroads, $1993 \ldots \ldots \ldots \ldots \ldots \ldots \ldots$. . . 93

43. U.S. Waterborre Trafflc: Coal and Coal Coke as Compared with Other Fossif Fuels and

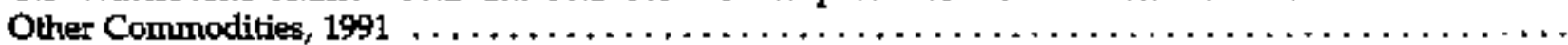




\section{Tables (Continued)}

44. U.\$. Coal Export Laading Terminals, $1990 \ldots \ldots \ldots \ldots \ldots \ldots \ldots \ldots \ldots \ldots \ldots \ldots \ldots \ldots \ldots \ldots$, 94

45. U.S. Coal Exports by Country of Destination, $1960-1993 \ldots \ldots \ldots \ldots \ldots \ldots \ldots \ldots \ldots \ldots \ldots \ldots \ldots 7$

46. U.S. Bituminous Coal Exports by Grade of Coal, $1975-1993 \ldots \ldots \ldots \ldots \ldots \ldots \ldots \ldots \ldots \ldots \ldots \ldots$, 98

47. U.S. Coal Produced for Export, by Origin and Destination, $1993 \ldots \ldots \ldots \ldots \ldots \ldots \ldots \ldots \ldots \ldots \ldots 99$

48. U.S. Air Pollutant Emission Estimates from Coal Combustion as Compared with Total Emisstions and Total Coal Consumption, Selected Years, 1970, 1980, 1990-1992 . . . . . . . . . . . . . . . . 104

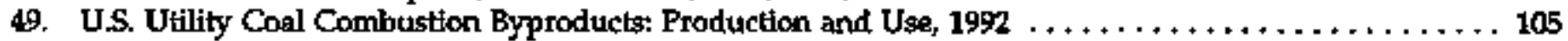

50. Trace Elements in U.S. Coal: Highest Average Concentration by Rank and Widest Range by

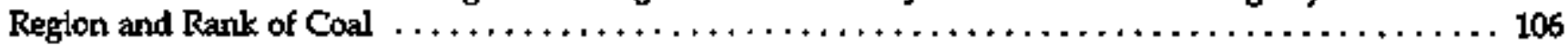

51. Classification of Coals by Rark $\ldots \ldots \ldots \ldots \ldots \ldots \ldots \ldots \ldots \ldots \ldots \ldots \ldots \ldots \ldots \ldots \ldots \ldots \ldots$

52. Approximate Weights of Unbroken (Solid) Coal in the Ground $\ldots \ldots \ldots \ldots \ldots \ldots \ldots \ldots \ldots \ldots$

53. Representative Analyses of U.S. Coal $\ldots \ldots \ldots \ldots \ldots \ldots \ldots \ldots \ldots \ldots \ldots \ldots \ldots \ldots \ldots \ldots \ldots$

54. Standard Anthracite Specifications $\ldots \ldots \ldots \ldots \ldots \ldots \ldots \ldots \ldots \ldots \ldots \ldots \ldots \ldots \ldots \ldots \ldots \ldots$

Figures $\quad$ Page

1. Approximate Heat Content of Different Coal Ranks $\ldots \ldots \ldots \ldots \ldots \ldots \ldots \ldots \ldots \ldots+\ldots \ldots+\ldots \ldots \ldots, 5$

2. U.S. Coal Deposits $\ldots \ldots \ldots \ldots \ldots \ldots \ldots \ldots \ldots \ldots \ldots \ldots \ldots+\ldots+\ldots \ldots \ldots \ldots+\ldots \ldots \ldots \ldots \ldots, 7$

3. Average Thickness of U.S. Coalbeds Mined, by State, in $1993 \ldots \ldots \ldots \ldots \ldots \ldots \ldots \ldots \ldots \ldots \ldots$.

4. U.S. Demonstrated Reserve Base of Coal, January $1,1993 \ldots \ldots \ldots \ldots \ldots \ldots \ldots \ldots \ldots \ldots \ldots \ldots 10$

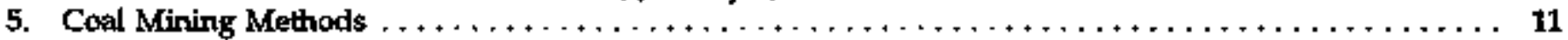

6. Underground Mining Systems $\ldots \ldots \ldots \ldots \ldots \ldots \ldots \ldots \ldots+\ldots \ldots \ldots \ldots \ldots \ldots+\ldots \ldots+\ldots \ldots \ldots 12$

7. Underground Coal Production by Mining Techniques, $1993 \ldots \ldots \ldots \ldots \ldots \ldots \ldots \ldots \ldots \ldots \ldots \ldots$

8. Area Surface Mining with Dragline and Shovel $\ldots \ldots \ldots \ldots \ldots \ldots \ldots \ldots \ldots \ldots \ldots \ldots \ldots \ldots+\ldots+\ldots, 15$

9. U.S. Coal Production, 1890-1993 $\ldots \ldots \ldots \ldots \ldots \ldots \ldots \ldots \ldots \ldots \ldots \ldots \ldots \ldots \ldots \ldots \ldots+\ldots+\ldots \ldots+17$

10. Baste Flow of Coal Through a Preparation Plant $\ldots \ldots \ldots \ldots \ldots \ldots \ldots \ldots \ldots \ldots \ldots \ldots \ldots \ldots \ldots \ldots, 27$

11. U.S. Daily Per Capita Coal Consumption, $1950-1993 \ldots \ldots \ldots \ldots \ldots \ldots \ldots \ldots \ldots \ldots \ldots \ldots \ldots \ldots \ldots \ldots$

12. Schematic of a Coak-Fired Power Plant $\ldots \ldots \ldots \ldots \ldots \ldots \ldots \ldots \ldots \ldots \ldots \ldots \ldots \ldots \ldots \ldots \ldots \ldots \ldots \ldots, 32$

13. Using Coal in a Blast Furnace to Make Iron $\ldots \ldots \ldots \ldots \ldots \ldots \ldots \ldots \ldots \ldots \ldots \ldots \ldots \ldots \ldots \ldots \ldots \ldots$

14 Iraduction of Coke and Coal Chemicals $\ldots \ldots \ldots \ldots \ldots \ldots \ldots \ldots \ldots \ldots \ldots \ldots \ldots \ldots \ldots \ldots \ldots \ldots, 34$

15. Schematic of Coal Gasification, Great Platus Synfuels Plant, Beulah, North Dakota ............... 35

16. Major Destinations of U.S. Caal Exports and Shipments from Selected U.S. Coal-Exporting Customs

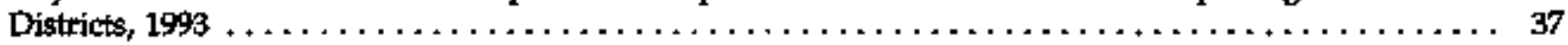

17. Selected Developments in the History of U.S. Coal Since $1880 \ldots \ldots \ldots \ldots \ldots \ldots \ldots \ldots \ldots \ldots$ 46

18. Estimates of Recoverable Coal Reserveg by Bhi/Sulfur Ranges and Region, January 1, 1992 . . . . . . 47

19. Regional Patterns of U.S. Coal Protuction, $1999 \ldots \ldots \ldots \ldots \ldots \ldots \ldots \ldots \ldots \ldots \ldots \ldots \ldots \ldots \ldots$

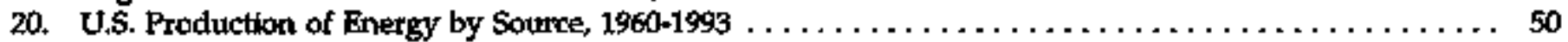

21. U.S. Consumption of Energy by Source, $1960-1993 \ldots \ldots \ldots \ldots \ldots \ldots \ldots \ldots \ldots \ldots \ldots \ldots$

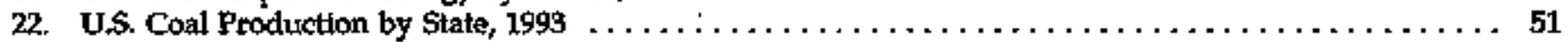

23. U.S. Coal-Producing Counties in the United States, $1993 \ldots \ldots \ldots \ldots \ldots \ldots \ldots \ldots \ldots \ldots \ldots \ldots$

24. Average Number of U.S. Coal Miners by Type of Mining, $1993 \ldots \ldots \ldots \ldots \ldots \ldots \ldots \ldots \ldots \ldots \ldots$

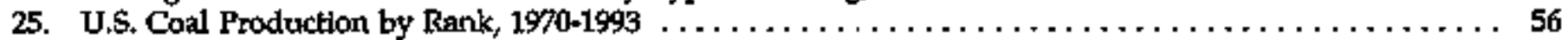

26. U.S. Coal Production by Region and Type of Mining, $1970-1993 \ldots \ldots \ldots \ldots \ldots \ldots \ldots \ldots \ldots \ldots \ldots$. 59

27. U.S. Coal Mining Fatalites, $1900-1993 \ldots \ldots \ldots \ldots \ldots \ldots \ldots \ldots \ldots \ldots \ldots \ldots \ldots \ldots \ldots \ldots \ldots 71$

28. Coal Distribution from the Three Leading Coal-Producing States, $1993 \ldots \ldots \ldots \ldots \ldots \ldots \ldots \ldots \ldots+\ldots 72$

29. U.S. Coal Production: End Use Distribution by Supplying Area, $1993 \ldots \ldots \ldots \ldots \ldots \ldots \ldots \ldots \ldots \ldots \ldots \ldots . \ldots 73$

30. Coal Shipments for U.S. Consumption by Supplying Areas and by Transportation Methods, 1993 . . . 74

31. U.S. Cosl Supply and Disposition Patterns, $1993 \ldots \ldots \ldots \ldots \ldots \ldots \ldots \ldots \ldots \ldots \ldots \ldots \ldots \ldots \ldots \ldots, 76$

32 U.S. Coal Consumption by End-Use Sector, $1950-1993 \ldots \ldots \ldots \ldots \ldots \ldots \ldots \ldots \ldots \ldots \ldots \ldots \ldots$ 
33. Coal-Fired Generating Units: Numbet, Generating Capability, and Electricity Generation in 1992

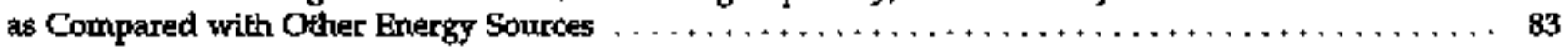

34. Percentage of Total Electricity Generating Capability Using Coal, by State, December 31, 1992 , . . . . 84

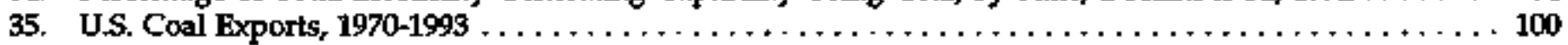

36. Word Coal Production and Leading Coak-Producing Countries, 1980-1992 . . . . . . . . . . . . . 101

37. Average Quality of Coal Produced for Power Plants by Producing State, $1993 \ldots \ldots \ldots \ldots \ldots \ldots \ldots \ldots \ldots$

38. Cost and Quality of Coal Shipped to Electric Utilites, by Origin, $1993 \ldots \ldots \ldots \ldots \ldots \ldots \ldots \ldots \ldots \ldots \ldots$ 


\section{A Brief History of U.S. Coal}

Coal was reportedly used by the Indians of the Southwest long before the early explorers arrived in America. The first record of coal in what is now the United States is a map prepared in 1673-74 by Louis Joliet. It shows "charbon de terra" along the Ilinois River in northen Ilinois. About a quarter of a century later, in 1701, coal was discovered near Richmond, Vinginia A map drawn in 1796 shows the location of several "cole mines" along the upper Potomac River, near what is now the border of Maryland and West Virginia. Before the end of the $1750^{\prime} \mathrm{s}$ conl was reported in Pernisylvania, Ohio, Kentucky, and West Virginia. Pennsylvania's anthracite deposits were found about 1762.

Blacksmiths in colontial days used small amounts of "fossil coal" or "stone coal" to supplement the charcoal normally bumed in their forges. Farmers dug coal from beds expased at the surface and sold it by the bishel. Although most of the coal for the Larger cities along the eastern seaboard was inported from England and Nova Scotia, some carre from Virginia. The first commercial U.S. coal production began near Richmond, Virginia, in 1748 , wore than a century before the beginning of the domestic oil industry. By the late $1800{ }^{\prime} s$, coal was being produced in most of the States.

Coal became the principal fuel used by locomotives. As the railroads branched into the coalfields, they became a vital link between mines and markets. Coal also found growing markets as fuel for households and steamboats. Another use of coal was to produce illturtnating oil and gas. In 1816, Baltimore, Maryland, became the first city to light streets with gas made from coal. With the beginning of the U.S. coke industry in the latter half of the $1800^{\prime} s$, coke soon replaced charcoal ws the chief fuel for iron blast furnaces. Briquetting of coal was introduced in the United States about 1870 . Coal-fired steam generators began to produce electricity in the 1880's. The first practical coal-fired electric generating station, developed by Thomas Edison, went into operation in New York City in 1882 to supply electrictity for household lights.

In the earliest mines, coal was quarried from beds that were exposed at the surface. To get more coal, the miners had to follow the coalbed underground. Before coal-cutting machines became available in the late $1800 \mathrm{~s}$, coal was mined underground by hand. Mechanical coal-loading equipment introduced in the early 1920 's replaced hand loading and increased productivity. Mules and, to a lesser degree, horses and oxen were used to haul coal and refuse in and around the eariy mines; a few dogs were used in small mines working thin coalbeds. In time, the antmats were replaced by electric locomotives, dubbed "electric mules," and other haulage equipment.

Strip mining began in 1866 near Danville, Illinois, when horse-drawn plows and scrapers were used to remove overbunder so the coal could be dug and hatuled away in wheetharrows and carts. In 1877, a steam-powered shovel excavated some 10 feet of overburden from a $3-$ foot-thick coalbed near Pittsburg, Kansas. In 1885, a converted wooden dredge with a 50-foot boom was used to uncover a coalbed under 35 feet of overburder. In 1910, surface mining was underway with steam shovels specifically designed for coal mining. 


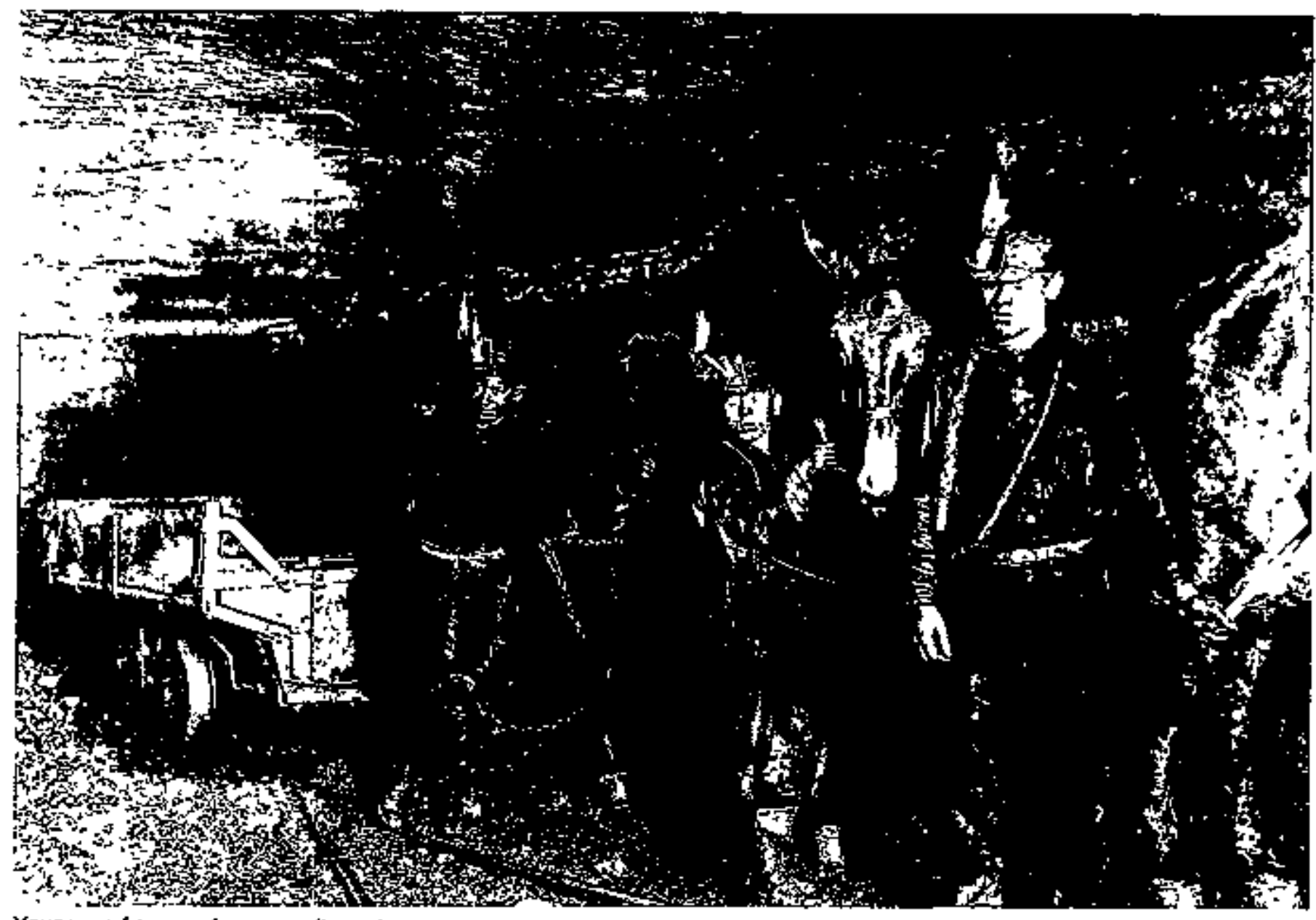

Young workers, mules, open-flame lamps, and sot hats were common in eanfy coal mines. 


\section{United States Coal: An Overview}

\section{Introduction}

The history of America's progress is inextricably linked to the use of coal from its abundant coal resources. In the early $1900^{\prime}$ 's, coal was so widely used that it reigned as the Nation's principal source of energy. Coal fueled industries, powered locomotives, and heated homes. The coal industry provided jobs for workers numbering in the hundreds of thousands and was the foundation of the economy in many areas.

Later, the Nation's use of conl slumped because of competition from other energy sources, chiefly oil and natural gas, which are cleaner and easier to use. The coal industry lost the railroads as consumers of coal, nearly all of the home heating market, and many of the smaller industries. Some predictions made after World War II saw the development of atomic power as leading to the demise of the coal industry. However, history has shown that coal has weathered competition from other energy sources, although the coal mining workforce has decreased dramatically because of extensive mechanization of mine operations.

The traumatic Arab oil embargo of the early 1970/s underscored the Nation's precarious dependence on foreign oil and renewed interest in the vast, widely distributed domestic coal deposits. Clean air legislation, ushered in around the same time, shifted coal development to the large, easily mined deposits of low-sulfur coal in the West. Since then, the market for coal has improved almost steadily, and the production and use of coal have reached unprecedented levels. Today, however, coal is used mostly to generate electricity and accounts for about half of the electricity generated anmually. So, through its role in generating electricity, coal has indirectly recaptured part of the market it lost years ago.

The coal industry has beconte the Nation's largest energy-producing industry, representing nearly onethird of U.S. energy production. Coal also accounts for almost one-fourth of total energy consumed and is the only energy source for which exports are greaber than imports. The coal industry is the Nation's leading mming industry, based on value of production. Of all mineral conmodittes mined, the quantity of coal currently produced ranks second only to that of crushed stone.

The importance of the coal industry to the U.S. econtomy is illustrated by a study made at Perusyivaria State University in 1994 for the National Coal Assoctation. Analyzing the coal industry's economic effects in 1992, the study found that, while the direct contribution of coal production that year was valued at $\$ 21$ billion, the industry's total contribution to the economy was $\$ 132$ billion through its impact on other business sectors. Similarly, the coal industry's workforce of about 136,000 persons, including non-production employees, was indirectly responsible for another 1.4 million jobs.

Ir 1993, the Nation consumed more than 2 million tons' of coal per day-about 20 pounds for each person every day. To produce the 1993 coal output, valued at about $\$ 19$ billion, more than 100,000 miners worked in some 2,500 mines. Although the coal produced was largely for domestic use, a sigrificant amount was shipped to other countries. These coal exports, averaging more than \$4 billion in value in recent years, help the Nation's balance of trade. The Nation has always had a trade surphus in coal. Internationally, the United States is prominent as both a producer and exporter of cost.

The magritude of arrual U.S. coal output-currently about I billion tons-is difficult to grasp unless it is placed in some farriliar perspective. One ton of broken coral occupies about 40 cubic feet, so the 1993 coal output would cover 1 square mile to a height of more than oneufourth of a mile. In other terms, the rate of coal production in 1993 averaged around 30 tons per second, enough to fill a railroad car every 3 seconds.

About 58 billion tons of coal have been produced in the United States since the first commencial mine was openet more than 200 years ago. Even so, U.S. coal deposits still contain more than 200 billion tons of minable coal, a reserve of energy that contributes to the

In thes report, "tons" refers to short tons (1 shout ton = 2,000 pounds). 
Nation's securlty. Futhermore, the coal deposits in some States have also become significant scutres of coalbed methane. Once considered ordy as a danger to miners, coalled methane is now being produced and added to the supply of natural gas.

Conl Data: A Reference provides an overview of the many facets of coal mentioned in this section. It spans a range of topics, covering coal deposits, reserves, mining, employment, transportation, use, and environmental issues. Its principat aim is to summarize basic trends, highlighting tactors that have influenced the use of coal and, therefore, controlled the rate of coal production. Also included is a review of new technologles being developed to increase the usefulness of coal as a natural resource, making it both a cleanerburning finel and a source of chemicals.

\section{The Nature of Coal}

Coal, sometimes called "Nature's Black Diamond," is a black or brownish-black, combustible, sedimentary organic rock that contains more than 50 percent cabonaceous material by weight. In popular usage, coal is often called a mineral because it was formed in the earth. However, the scientific use of the term "mineral" is reserved for a natually occurring inorganic material that has a definite chentical composition and a regular internal struchure. Coal is of organic ortigin and has neither of these.

Cornpared with other rocks, coal is relatively light, a solid piece weighing about 80 pounds per cubic foot, less than half the weight of granite, limestone, or most other rocks. Coal is also a relatively soft rock, more easily excavated than most other mined matertal.

Coal is called a fossil fuel because it is derived from plants that grew in vast swamps millions of years ago and were later buried by sediments when the land subsided. Geological and themical processes involving high pressuses and temperatures, working over vast periods of time, compressed and altered the plant remains, increasing the percentage of carbon present, and thus producing the different ranks, or varieties, of coal: lignite, subbstuminous, bitumninous, ant anthracite. Of the various coal ranks in the United States, bituminous coal is the most abundant and widespread. The water-saturated plant debris called peat is not considered a rank of coal, although it is the first stage in the alteration of plants to coal. With increasing rank, or degree of coalification, coal becomes harder and brighter, and its heat value rises. Coal rank is commonly determined by a combination of heat vahue and chemical analysis of organic matter. The rank of coal can also be determined by measuring the intensity of light reflected from its vitrinite, one of the macerals in coal. Macerals are the combustible organic portions derived from plant substances and comprise three microscopic groups: vitrinite, exinite (or liptinite), and inertinite. The reflectivity of visinite increases with coal rank. Macerals are also helpful in identifying and correlating different coals and in predicting the coiking properties of coal and coal blends.

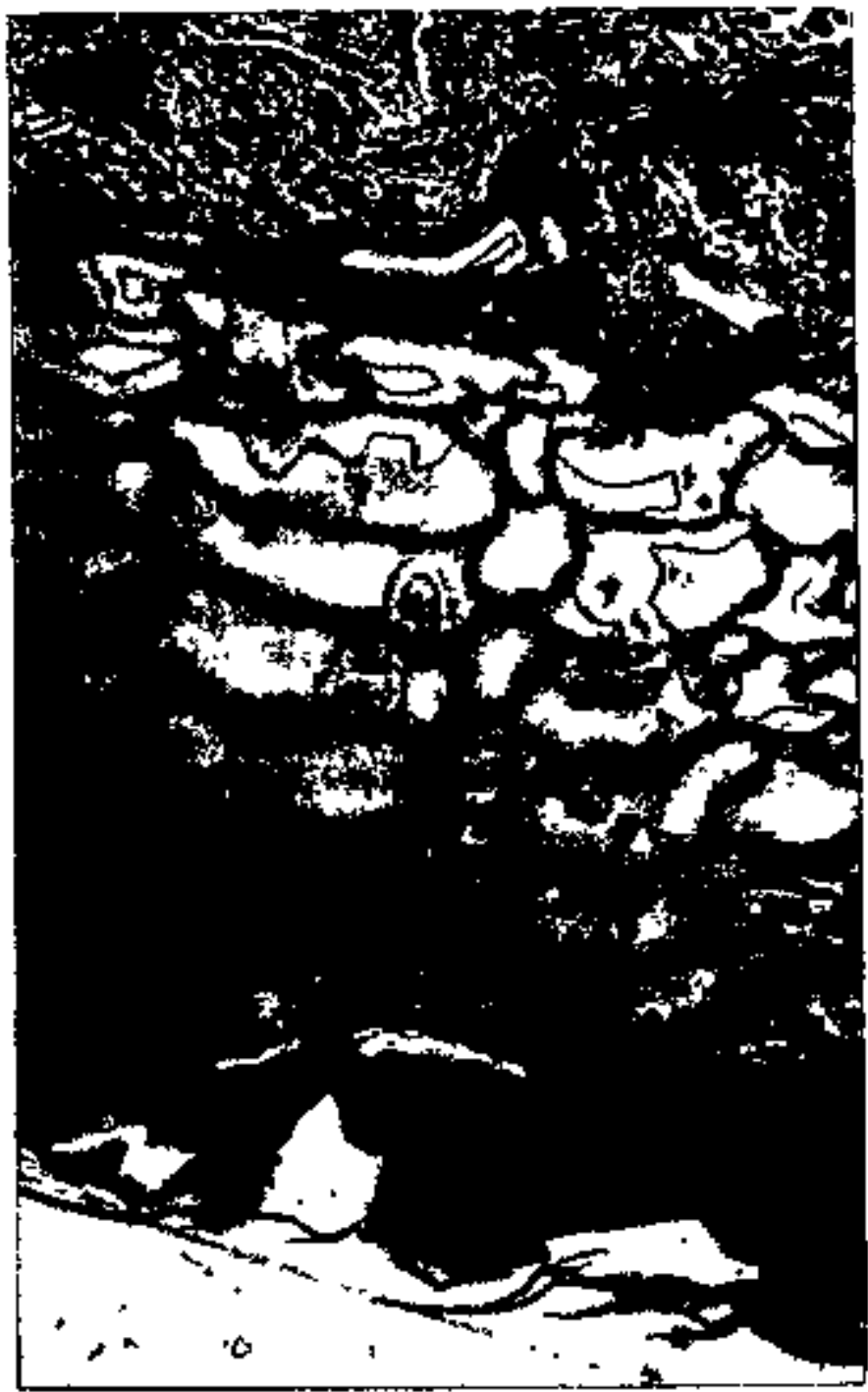

Fossil plant malerial is revealed in this photomicrograph of subbituminous caal from Wyoning's Powder fiver Busin. As an indication of magnification, the longer side of the pholo represents 0.26 milinieters.

Coal occurs in beds, sometimes called "seams" or "veins," that are interlayed between beds of sandstone, shale, and limestone. The thin layers of shale ("partings") sometimes found in a coalbed are mineral sediments that settled from muddy flood watess whlle the vegetable mafter was accumulating. Coalbeds range 
In thickness from less than an inch to more than 100 feet. According to some estimates, an accumulation of 3 to 10 feet of compacted material was needed for each foot of bituminous coal. Based on estimates that hundreds of years were needed to build up enough plent material to make a foot of bibuninous coal, thick coalbeds represent accumulations of plant material spanning many thousands of years. Although generally flat lying, coalbeds are sometimes inclined, folded, or faulted as a result of geologic forces.

Coal is a complex materlal, Its chemical structure still not completely understood. It is composed chiefly of carbon, hydrogen, and oxygen, with smaller amounts of sulfur and nitrogen and variable quantilies of trace elements ranging from aluminum to zirconium. All but 16 of the 92 naturally occurring elements have been detected in coal, mostly as trace elements below 0.1 percent (1,000 parts per million, or Ppm). Coals of the same rank may appear similar, but their compositions can vary widely, not only from deposit to deposit but also within the same coalbed, because of differences in the environment of the coal swamps and the nature of the original plant debris. The elpments fotmd in coal were introduced into the coalbed in one or more different ways; as material washed into the coal swamp, as a biochemical precipitate from the swamp water, as a minor constituent of the original plants, or as a later addition, after the coal was formed, primarily by ground water.

Fossil plant debris gives coal its most obvious and most useful characteristic, namely, that it can be bumed. The heat energy of coal ranges from an average of 13 miltion British thermal units (Btu) per ton for lignite to about 30 million Btu per ton for some bituminotus coals (Figure 1), Most of the heat produced from coal is generated from carbon, by far its major component, wlth the amount present typically more than 70 percent. Althaugh hydrogen generates about four times more heat per pound than carbon, it accounts for a gmall part of coal (generally less than 5 persent) and not all of this element is avatlable for heat During combustion, part of it combines with oxygen to fonm water vapor. The higher the oxygen content of coal, the lower its heating value. This inverse relationship occurs because the oxygen in the coal is bound to the carbon and has, therefore, already partially oxidized the carbon, decreasing its ability to generate heat The amount of heat from the combustion of sulfur in coal is very small. Because coal has a high ratio of cabon to hydrogen, the buming of coal releases more carbon dioxide per unit of heat than does the buming of oil or natural gas.
Figure 1. Approximate Heat Content of Different Coal Ranks'

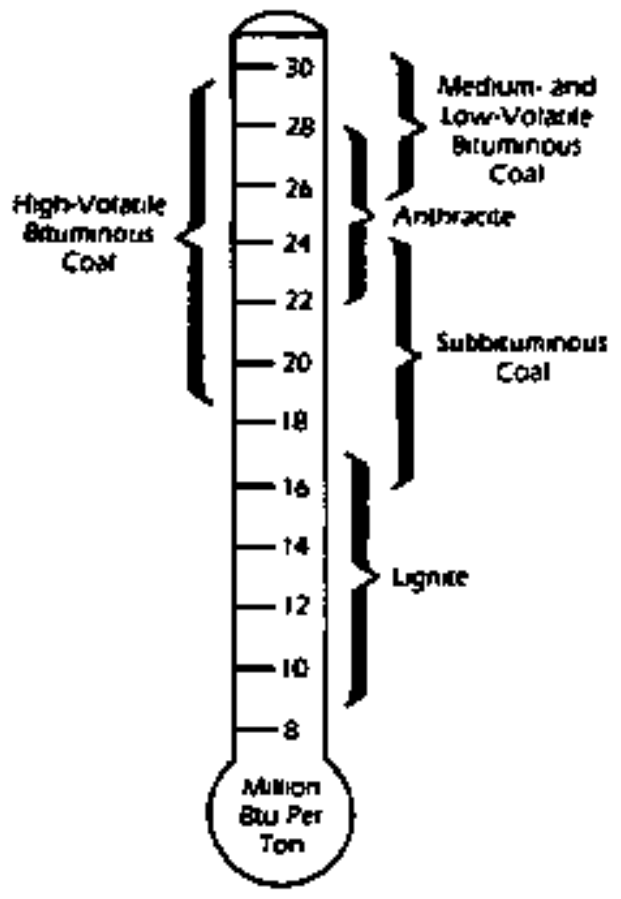

'As received. (Includes natura' molstere and combusilible and incombusitble materials.)

The heat content, or Bitu value, of coal is approxinately radated to ks rank, except for anthracite.

Although the quantity of cool produced and consumed is commonly measured in tons, the heating value of a ton of coil varies considerably, reflecting differences by rank as well as variations within rank due to the kinds of plant material from which the coal was formed. For instance, the heating value of bituminous coal delivered to electric utilities in 1993 averaged 24 million Btu per ton, but the range was from 20 million to 27 million Beu per ton. Similarly, the heating value for subbituminous coal averaged 18 million $B$ tu per bon but it ranged from 16 million to 19 million Bfu per ton. Ligndte's average heating value of 13 milliton Bta per ton was based on a range of 12 million to 14 million Btu per ton. Anthracite prociuction averaged about 23 milition Btu per ton. Using these averages, 1.3 tons of subbituminous coal, 1.8 tons of lignite, or a little more than 1 ton of anthracite wottld be needed to protuce the amotunt of heat in 1 ton of bituminous coal. For this reason, coal purchases are often priced in terms of "dollars per mitlion Bhi" in addition to "dollars per ton." 
Because the annual "mix" in the ranks of coal comprising total coal production includes growing shares of low rank coals, which generate relatively less heat, the average heat content of U.S. coal production is deslining. Currently, it is about 22 million Btu per ton. This is approximately equivalent to the energy obtamed by burning 21,000 cubic feet of natural gas, 160 gallons of distiliate fuel oil, or 1 cord of seasoned hardwood.

Among the various elements in coal, sulfur is the most undesirable. Burning converts the sulfur in coal mostly into sulfur dioxide, an air pollutant as well as the cause of corrosion and deposits in boilers. Sulfurs in mine wastes inhibits the growth of vegetation and causes stream pollution. Sulfur in coking coal used by the steel industry lowers the quality of both the coke produced and the resulting iron and steel products; consequently, coal with a low sulfur content is required for making coke. Various laws have been enacted to limit the amount of sulfur released to the environment. The sulfur content (by weight) of the coal produced for electric power plants, the largest market, in recent years ranged from less than 1 percent to about 4 percent, and averaged 1 percent (20 pounds per ton).

Sulfur occurs in coal in three forms: (1) iron sutfides (pyrite and marcasite), (2) secondary sulfates (gypsum and hydrous ferrous sulfate), and (3) organic sulfur chemically bonded to the coal-forming plant material. Most of the fron sulfides occur in the form of pyrite, which is distributed in many ways: as lenses, bands, fractures, and nodules, and as finely disseminated particles The larger particles can be partly removed by conventional clearing processes, but the fine particles are difficult to remove undess the coal is finely crushed and the pysite separated by special treatment. Sulfate sulfur is less easily removed; however, it is normally present in small amounts (generally less than 0.05 percent) and usually of no great concern. Organic sulfur predominates in low-sulfur coal. As the total solfur content of coal increases, the amount of organic sulfur can sise to more than 1 percent. Organic sulfur carnot be removed by conventional coal-cleaning processes.

High wulfur coal is a product of swamps that were covered by sea water. Bacteria in the swamp converted the stulfate in the sea water into pyrite that became part of the coel. Low-sulfur coal deposits were developed primarily under fresh-water conditions.

Although the subbituminous coals and lignites mined in the West contain much lower levels of stulfur than do typical bituminous coals, they contain fairly high levels of the alkali metals sodium and potassium. These elements, which generally are chemically bound to the organic coal matrix, affect the physical and chemical properties of the coal ash. Boilers using these coals are specially designed to avoid serious ash-related equipment malfunctions.

Minerais are the incombustible matter in coal that becomes ash after burning. Minerals represent the inorganic parts of coal and include clay (the most abundant inorganic constittient), carbonates, sulfides, and quartz The ash content of coal produced for electric power plants in recent years ranged from about 5 to 19 percent (by weight) and averaged about 10 percent (about 200 pounds per ton). Ash not only poses significant disposal problems, but it can form incombustible residures in furnaces, causing combustion problems and erosion of boiler components. Sonve ash is used in land fills and in making concrete and cinder blocks.

Methane in coal is the result of the chemical and physical processes involved in coal formation. The methane is contained within the structure of the coal and in fractures in the coalbed. Higher rank coals such as bituminous coal generally contain more methane than low eanks such as lignite. Because coal formed under high pressure is apt to contain more methane than otherwise, the methane content of coalbeds increases with depth.

\section{U.S. Coal Deposits}

The United States contains some of the world's largest coal deposits. Coal is present in 38 States and underlies a total of 458,600 square miles or 13 percent of the land area of the United States (Figure 2). The U.S. Geological Survey has identified more than $\mathbf{4 0 0}$ fields and small deposits of coal in the United States. They were formed during periods of Earth's history when the face and climake of what is now North America were markedly different than they are today. The coal deposits in the East date back mainly to the Pentsylvanian period of the Earth's geologic history, approximately 300 million years ago, long before the age of dinosaurs. By contrast, most of the coal in the West is geologically younger, formed less than 140 million years ago in the Cretaceous period, when dinosaurs were alive, and in the subsequent Tertiary period, when they became extinct.

Coal in the East generally occurs in beds that tend to be less than 15 feet thick Geological conditions in the East prevented the coal-forming materjal from butiding up; instead, they led to the formation of numerous coalbeds 


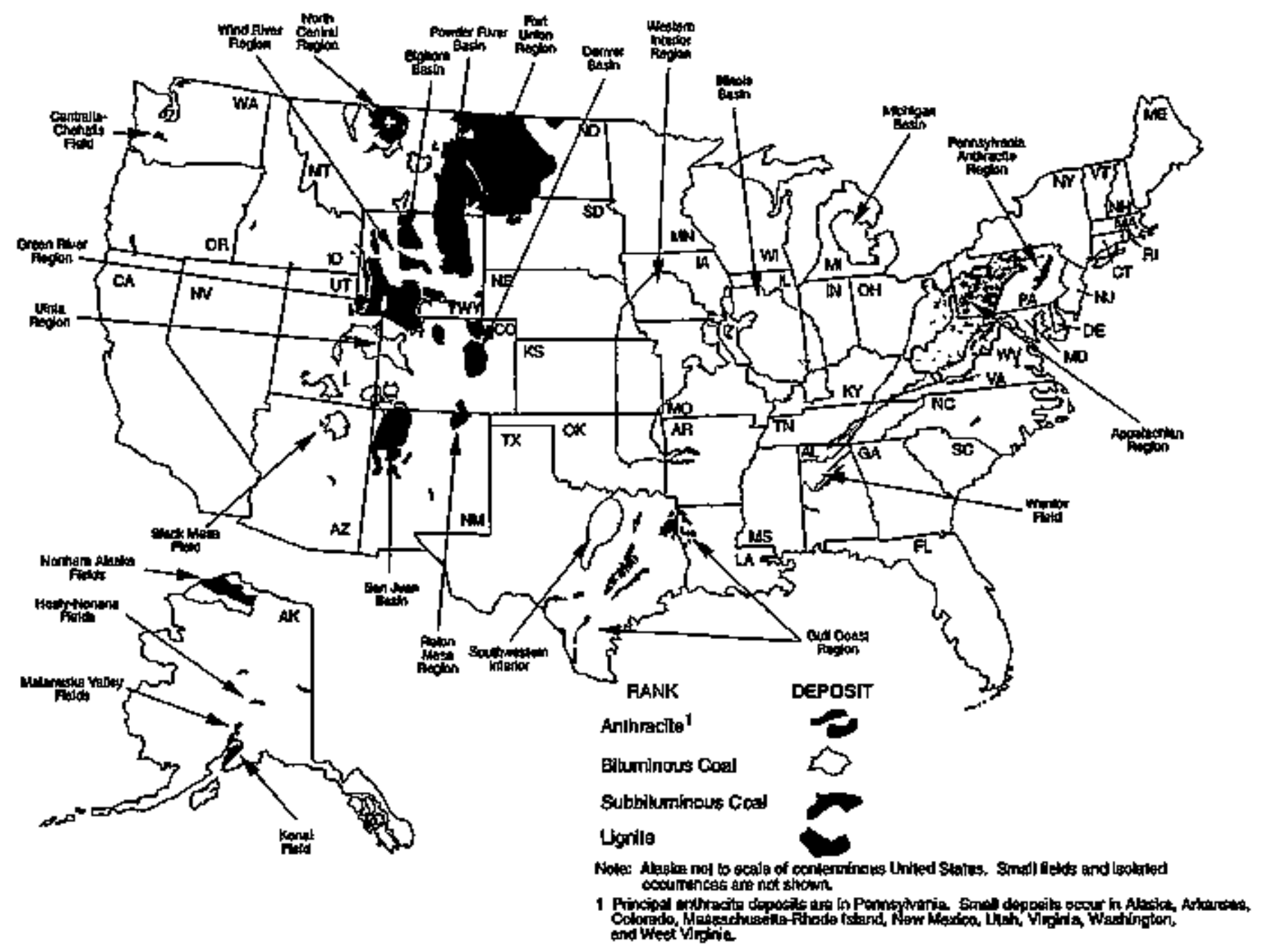

Coal is found in 38 states, underlying 458,600 squere miles, about 13 percent of the total land srea.

Sources: U.S. Geological Survey, Coallialds of the United States, 1960-61 and Coal Map of North Americe, 19a8; Texas Bureau of Economic Geology, Lignlte Resourcas in Texas, 1980; and Lotisiand Geological Survey. Near Surface Lignite in Louisiana, 1961.

located between other strata in repetitive sequences. By comparison, thicker coalbeds are common in the West, particularly in Wyoming, where geological conditions enebled lerge amounts of vegetation to accumulate. Although about 300 coalbeds were mined across the United States in 1993, nearly half of the coal produced was from only 10 beds (Table 1). The average thickness of all coalbeds mined ranged widely, from less than 2 feet to about 65 feet (Figure 3). Individual coalbeds commonly cover large geographic areas. For instance, the heavily mined Pittsburgh coalbed underlies parts of Pennsylvania, West Virgiria, Ohio, and Maryland; the
Wyodak coalbed, the Nation's leading source of coad, is estimated to cover at least 10,000 square miles in the Powder River Basin of Wyoming and Montana, acconding to the Wyoming State Geological Survey.

The most important coal deposits in the East are in the Appalachian Region, an area encompassing more than 72,000 square miles and parts of ninte States. The region contains the Nation's principal deposits of anthracite (in northeastern Pennsylvania) and large deposits of lowand medium-volatile bituminous coal. Historically, the Appalachian Region has been the major sourse of U.S. 
Table 1. U.S. Coal Production from the 10 Leading Coalbeds, 1993 (Million Short Tons)

\begin{tabular}{|c|c|c|}
\hline Carlbet Name & Produetlon & $\begin{array}{c}\text { State with } \\
\text { Largent } \\
\text { Prodartion by } \\
\text { Coalbed }\end{array}$ \\
\hline Wyotak $\ldots \ldots \ldots \ldots \ldots$ & 185.7 & WY \\
\hline Fithobugh $\ldots \ldots+\ldots \ldots \ldots$ & 49.4 & WN \\
\hline No. $9 \ldots \ldots \ldots \ldots \ldots \ldots$ & 34.8 & KY(M) \\
\hline Hazard No 5-A,$\ldots+\cdots++++$, & 32.4 & KY(E) \\
\hline No $6 . \ldots \ldots \ldots \ldots \ldots \ldots$ & 90.7 & IL \\
\hline Buulah-Zap $\ldots \ldots \ldots \ldots \ldots$ & 27.7 & ND \\
\hline Hazand No. 4. . . . . . . . & 24.5 & KY(E) \\
\hline Lowrar Kutarining $\ldots \ldots \ldots+++$ & 22.6 & $w$ \\
\hline Lower Ekhom $\ldots \ldots \ldots \ldots$ & 18.0 & KY(E) \\
\hline Aasebud $\ldots \ldots \ldots \ldots \ldots$ & 16.2 & MT \\
\hline Tatal $\ldots \ldots \ldots \ldots \ldots \ldots$ & 442.4 & - \\
\hline Percentuge af U.s Toted . . . . & 46.8 & - \\
\hline
\end{tabular}

Tame most conimon'y used.

- $=$ Not applicabite.

Nole: Totel does not equel sum of comportents because of independent rounding.

Soure: Energy Information Admintstiallon, Coal Indistiy Annuad 1908, DOEGAA-0684(94) (Washington, DC, December 1994).

coal, accotinting for about three-fourths of the total annual production as recently as 1970. Although the region's output currentiy is less than half of the national total becauge of increased coal production in the West, it continues to be the principal source of bituminous coal (moluding coking coal) and anthracite. The number of coalbeds mined in the Appalachian Region reaches more than 60 in West Virginia, with the bed thickness generally ranging from 3 to 8 feet. In the northern part of the region is the Pittsburgh coalbed, an important source of coal during the development of the U.S. iron and steel industry. For many years the Pittsburgh coalbed was the leading source of coal, but it now ranks second to the Wyodak coalbed in Wyoming. The intensely folded and faulted anthracite fields of northeastem Penusylvaria once supplied a large amount of coal for domestic heating, a major part of it from a series of beds comprising the Mammoth coal zone. Two important sources of bituminous coal in the southern part of the Appalactian Region are Alabama's Blue Creek and Mary Lee coalbeds.

In contrast with the concentration of coal in Appalachia, the coal deposits in the interior region of the United States occur in several separate basins located from Michigan to Texas. The northern part of the region contains large deposits of high-volatile bituminous coal, but their generally high percentage of sulfur and ash hampers their use as a fuel and for coke production. The major sources of bituminous coal are two coalbeds commonly known as No. 6 and No. 9. but also known bocally by other names. These beds, which average about 6 feet in thickress, account for a large share of the coal produced in Illinois, Indiana, and western Kentucky. A small area of anthracite is present in Arkinsas. In the Gulf Coastal Platu in the southem part of the region are large deposits of lignite that have been used for electilcity generation in Texas since the $1970^{\prime} \mathrm{s}$ and in Louisiana since the 1980's. The most important lignite beds are in a succession of strata known as the Wilcox Group and are generally 3 to 10 feet thick.

The westem part of the United States has a number of coal basins that contain all ranks of coal. The largest lignite deposit is in the northem Great Plains, underlying parts of North Dakota, South Dakota, and Montana; most of the lignite produced is from the Beulah-Zap bed in North Dakota. In the nearby Powder River Basin of northeastem Wyoming and southeastern Montana is the Nation's major source of low-sulfur subbituminous coal, used primarily for electricity generation. The basin has been the fastest growing coalproducing area in the past two decades and today accounts for about half of the coal nined in the West. The Powder River Basin contains the Wyodak coalbed, which is the leading source of U.S. coal production and one of the thickest coalbeds, averaging 70 feet and exceeding 100 feet in places. The principal deposits of bituminous coal mined in the West are in Utah, Colorado, and Arizona. Alaska has deposits of all coal ranks, but currently the only production is subbiturrinous coal from the Nenana field, north of Anchorage.

\section{Resources and Reserves}

Coal is by far the Nation's most aburdant fossil fuel, with the total resources of both identified and undiscovered coal estimated at nearly 4 trillion tons. The quantity of coal considered bechnically and commercially minable constitutes a demonstrated reserve bage currently estimated at more than 400 billion short torss. About half of the tonnage is bituminous coal (Figure 4), concentrated in Appalachia and the Interior Region; around 38 percent is subbituminous cosl in the West, about 9 percent is lignite, located mostly in the West and the Interior Region; and 1 percent is Perusylvanta anthracite. Underground miring is required for about two-thitrds of the reserve base; the rest can be surface mined. The largest reserves of low-sulfur coal are in the West. By contrast, the coal reserves with the highest heat content are mostly in the East. 
Fighre 3. Average Thickness of U.S. Coalbeds Wined, by State, in 1993 (Weighted Average in Feet)

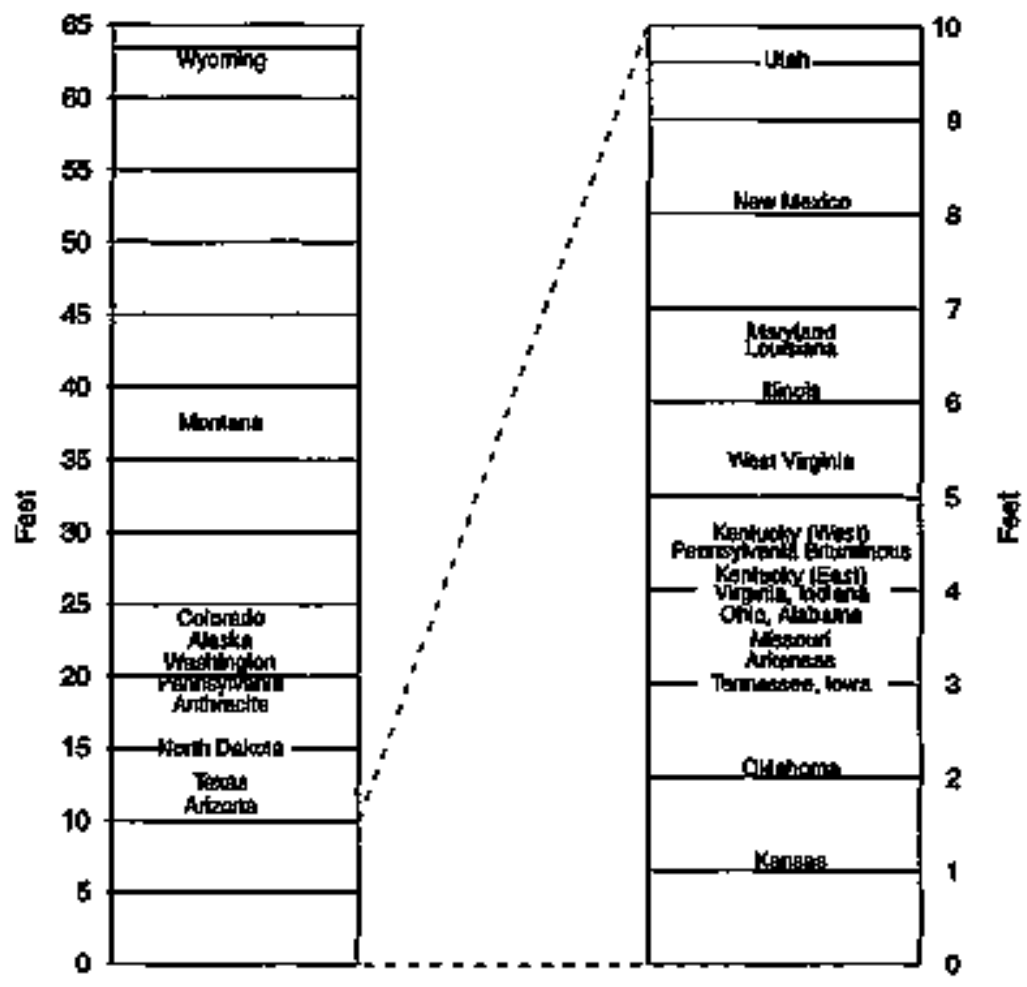

The thickest coalbeds mined in the United States are in the West. The average thickness of afl coalbeds ninad in rag3 was about 22 feot

Source: Energy information Admintairation, EAA.7A, "Coal Production Report."

The amount of coal that can actually be recovered from the reserve base varies from area to area and ranges from 40 percent at some underground mines to more than 90 percent at some surface mines. The recovery rate is lower for tmderground mining because some coal must be left untouched to form supporting pillars to prevent the mine from collapsing and the surface from subsiding. At both underground and surface mines, geologic features such as folded, faulted, and interlayered rock strata can reduce the amount of coal that can be recovered. In some areas, coal deposits underlie towns and cities and consequently may not be mined. Other factors that init mining include environmental and legal testrictions, economic constraints, lack of suitable technology for using low-quality coal, and the fact that many of the highest quality and most accessible coal deposits have already been mined. Nevertheless, for the Nation as a whole at least half of the reserve base-about 265 billion tons - is estimated to be recoverable. U.S. recoverable coal reserves are estimated to be the second largest in the world, slightly below those in the former Soviet Union.

Based on coal quality, as measured in pounds of sulfur enitted per million Btu, U.S. recoverable coal reserves include an estimated 100 bilition tons of low-sulfur coal (0.60 pounds or less of sulfur per million Btu), with 87 percent of this in the West. Mediun-sulfur recoverable coal reserves (0.61-1.67 pounds of sulfur per million Btu) are estimated at 84 billion tons, of which 62 percent is in the West and 24 percent in Appalachia. High-sulfur recoverable coal reserves (more than 1.67 pounds of sulfur per million Btu) total 80 billion tons, and are mostly in the interior region (60 percent) and Appalachia (28 percent). 
Figure 4. U.S. Demonstrated Roserve Base of Coal, January 1, 1993

(Billion Short Tons)

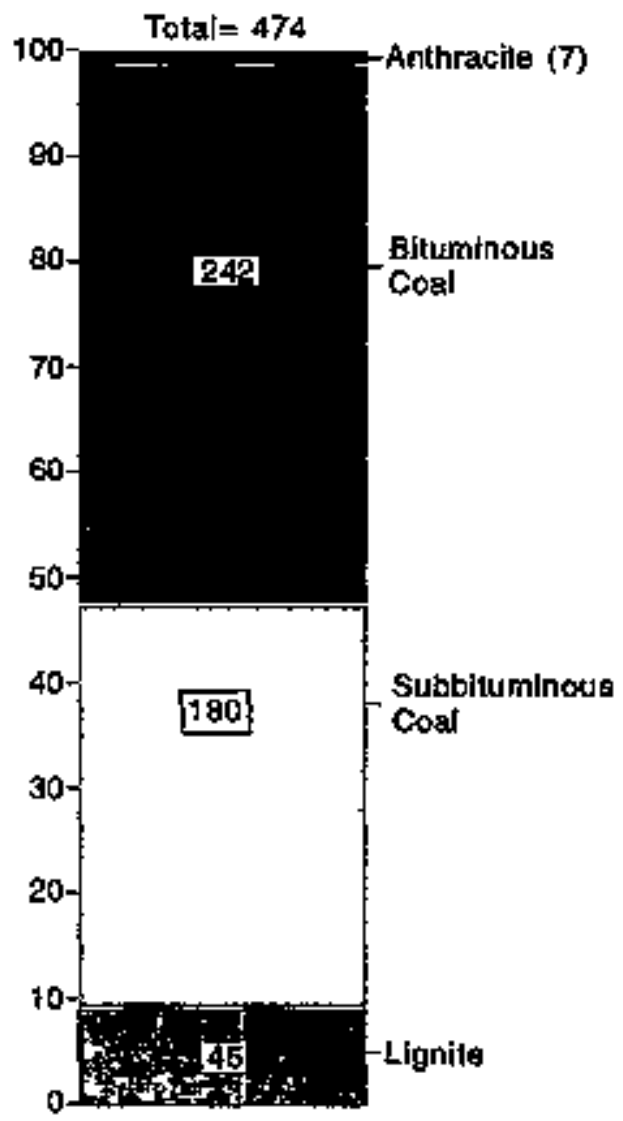

The neserve base is comprised chiafly of two ranks of coal. biluminous and subblituminous.

Source: Energy Information Administralion, Coes Production 1992, DOEEIA-0118192) (October 1958).

The recoverable coal reserves reported at active mines in 1993 totaled nearly 22 billion tors. About 15 billion tons were at surface mines, mostly in the Western Region. Of the 7 billion tons in undergtound mines, nearly two-thitds were in Appalachia.

Another energy source from coal is methane, a gas formed by the decomposition of the orgaric matter in coal. Coalbed methane is recovered in some States (for example, Alabama, New Mexico, and Wyoming) and added to the supply of natural gas, which is composed chiefly of methane. Proved reserves of coalbed methane total 10 trillion cubic feet, located mostly in the San Juan Basin of Colorado and New Mexico. The recoverable resource base for coalled methane currently comprises an estimated 90 trillion ctibic feet in the lower 48 States and 57 trillion cubic feet in Alaska.

\section{Mining}

Once a coal deposit has been selected for mining, some 4 to 7 years of planning and development are needed before production begins. Apart from the market for coal, the questions that must be addressed include land ownership, mirseral nights, the quality and quantity of the available coal, and the method of mining and transporting the coal.

The mining method used depends on the depth of the coalbed from the surface and the character of the terrain (Figure 5). Coalbeds deeper than 200 feet are usually mined by underground methods. Those that are at shallower depths are worked by surface methods.

Although most underground mines are less than 1,000 feet deep, several reach depths of about 2,000 feet. Underground mines are classified according to the type of opening, or entry, used to reach the coalbed; sone mines have several different openings. A drift mine is one that has a horizontal entry to a coalbed in a hillside. In a slope mine, the entry is inclined from the surface to the coalbed. A shaft mine, equipped with elevators, provides vertical access to a coalbed generally deeper than one reached by a slope mine. In addition to the passages providing entry to the coalbed, a network of other passages are also dug to provide access to various parts of the mine and for ventilation.

When the coalbed is reached, it is sectioned into panels, or blocks, several hundred feet wide and several thousand feet long (Figure 6). The actual mining of these blocks is accomplished by three techlutques: roomand-pillar, longwall, and shortwall sometimes several techntques are used at the same time in different sections of a mine.

Most underground coal is mined by the room-and-pitlar system (Figure 7). With this system, the miners extract the coal by cutting a series of rooms into the coalbed and leaving pillars, or columns of coal, to help support the mise roof. As miring advances, a g\#tilike pattern is formed in the parsel of coal, which is about 400 feet wide and more than half a mile long. Generally, the rooms are 20 to 30 feet wide and the pillars 20 to 90 feet wide; the height usually is the same as the coalbed thickness. When mining reaches the end of the panel, the direction of mining usually is reversed. During this "retreat" phase of mining, the miners recover as much coal as possible from the pillars in a 


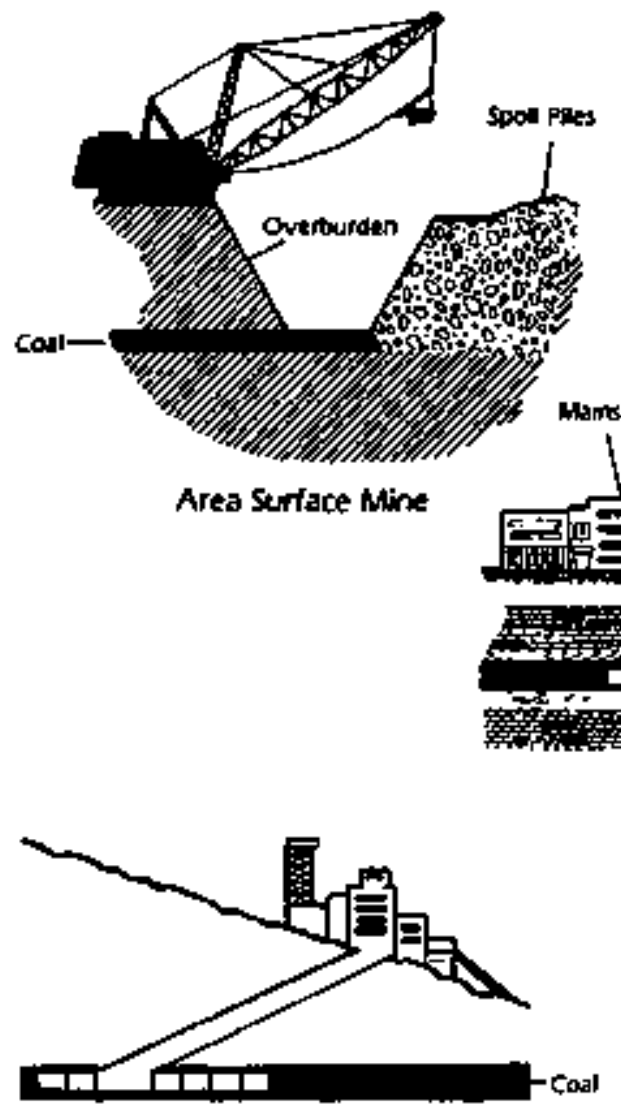

Slope Mine

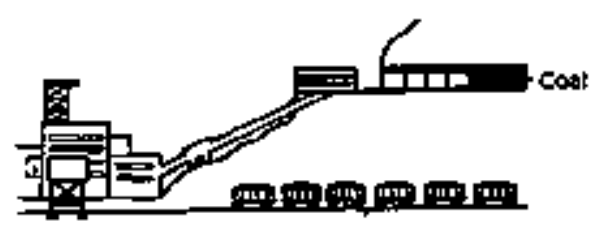

Drift Mine

The mothad of mining a coal deposit depends on the depth of the carabed and the nelure of the torrain.

systematic manner until the roof caves in. When this phase of mining is completed, the rea is abandoned. Although the goal is to extract all of the conal in the panel, this is not always possible because of natural restraints, such as poor mine roof and floor conditions. Furthermore, pillars are usually left to prevent subsidence of the Iand surface above the mine. Pillars that are not mined include those along property lines, around shaft bottoms or portals, and around oil and gas wells that penetrate the coalbed. Generally, 50 to 60 percent of the minable coal is recovered with roomand-pillar mining.

Two basic variations are used in room-and-pillar mining: (1) conventional mining, the oldest which consists of a series of operations that involve cutting the coalbed so it breaks easily when blasted and then loading the broken coal; and (2) contmutous mining, which uses a machime called a continuous miner that combines culting, drilling, and loading cool in one operation and requires no blasting. Because of the steps involved, conventional mining requires a larger crew at the coal face-for example, 10 miners as compared with 6 for continuous mining. Generally, mining advances into the coalbed in steps of about 10 feet for conventional mining and about twice that in continuous mining. Since the 1950 s, continuous mining has thcreased and now accounts for 56 percent of the coal output from underground mines, whereas the share from conventional mining has fallen to about 12 percent. Regardless of the mining variation used, roomard-pillar mining usually is not suitable for coalbeds at depths greater than about 1,000 feet. As depth increases, larger pillars are needed to support the overfying strata and less coal can be produced. 
Figure 6. Underground Minling Systems

\section{Room-and-Pillar Mining}

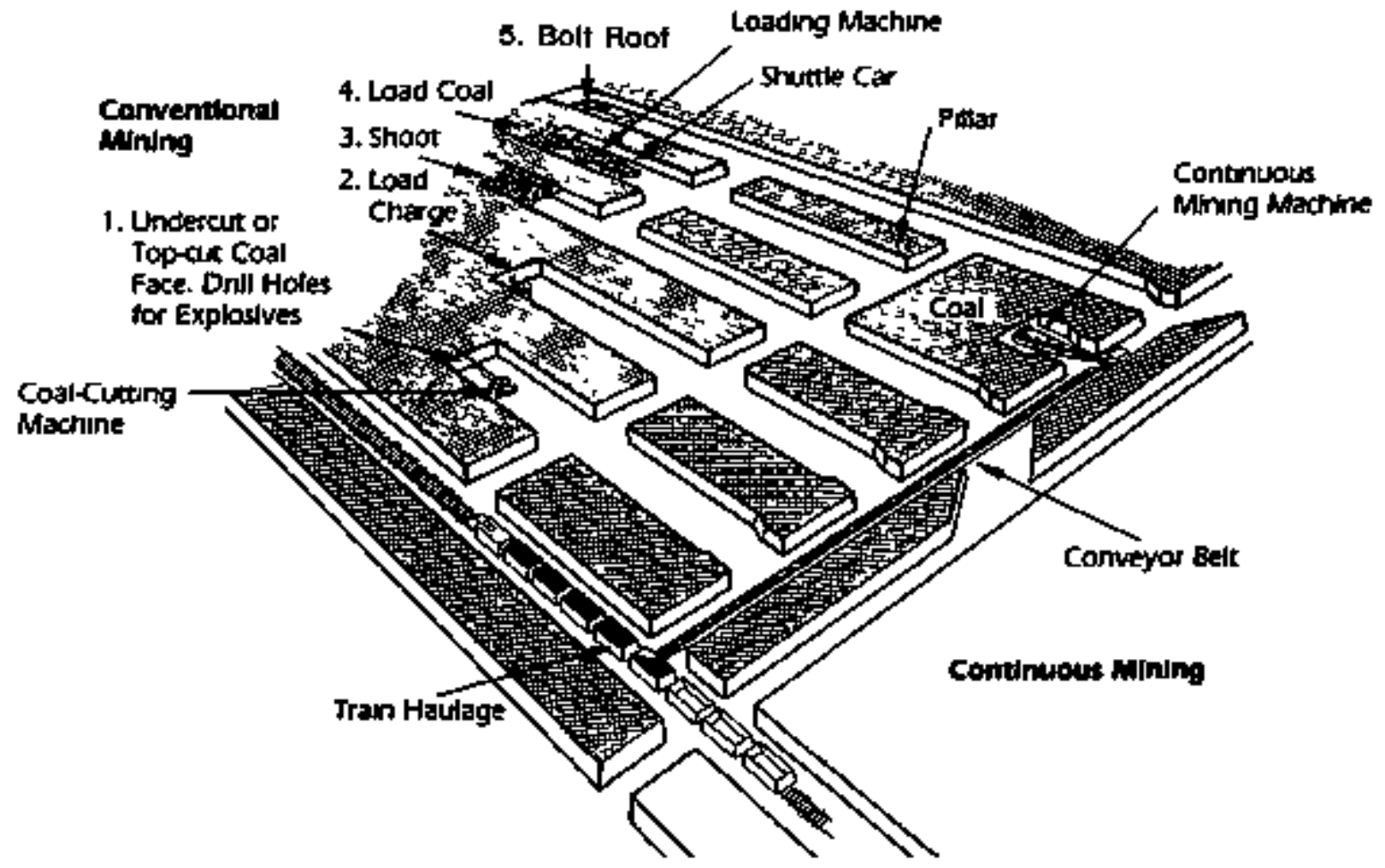

\section{Longwall Mining}

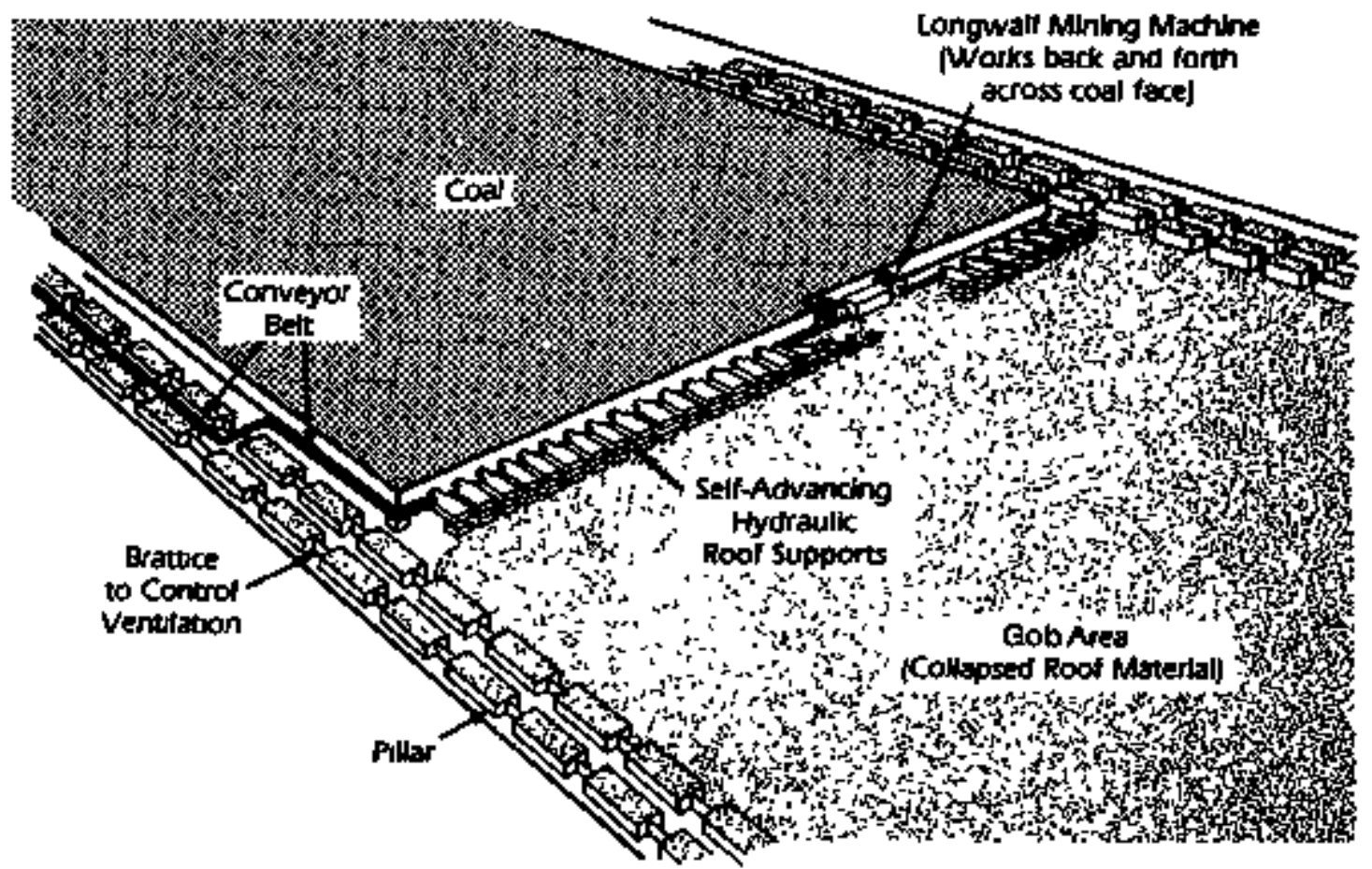

Room-and-pilks mining is the most common way to mine coal undergound. Longwall mining is usad to mine large blacks of coal

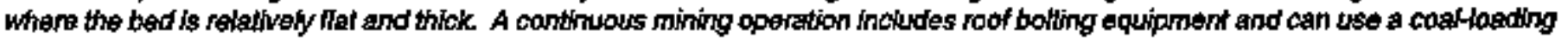
machine and shutlle cers (not strown) instead of a conveyor belt. 
Flgure 7. Underground Coal Production by Mining Techniques, 1993

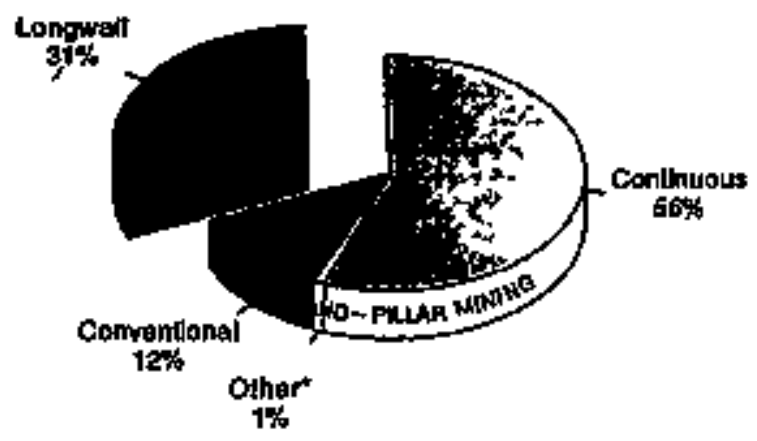

includes ehortwall, scoop loading, and hand loading.

Undergrothn cad is mined mostly with continuous maning mathises, which dig and load coul in one operation.

Source: Energy Informalion Administration, Coal indistly Annusl 1993, DOEJEIA-0584(93) (W/ashington, DC, December 1994).
The second technique of underground coal mining is longwall mining, which is gaining importance in the Urited States and can be used at greater depths than room-and-pillar mining. Nearly one-third of the coal currently produced underground is from about 100 longwall mining operations, most of them in the Appalachian Region. In longwall mining, a cutting machine operates back and forth across a panel of coal averaging about 800 feet in width and 7,000 in length, with the broken coal removed from the coal face by an armored flexible conveyor. Two types of cutting devices are used, shearers and plows. The shearer, by far the more widely used, has a large drum-shaped cutting head that strips 20 to 36 inthes from the coal face on each pass. It rides on a special track on the armored flexible conveyor. A plow is a much simpler machine that is blade-like and fitted with bits or a saw-tooth edge that cuts the coal face into slices up to 6 incties deep as the plow is pulled across the coal face. Longwall mining is done under movable hydraulic roof supports, or stields, that are advanced as the bed is cut; the roof in the mined-out ares is allowed to fall as mining advances, forming an area of broken rock called "gab"

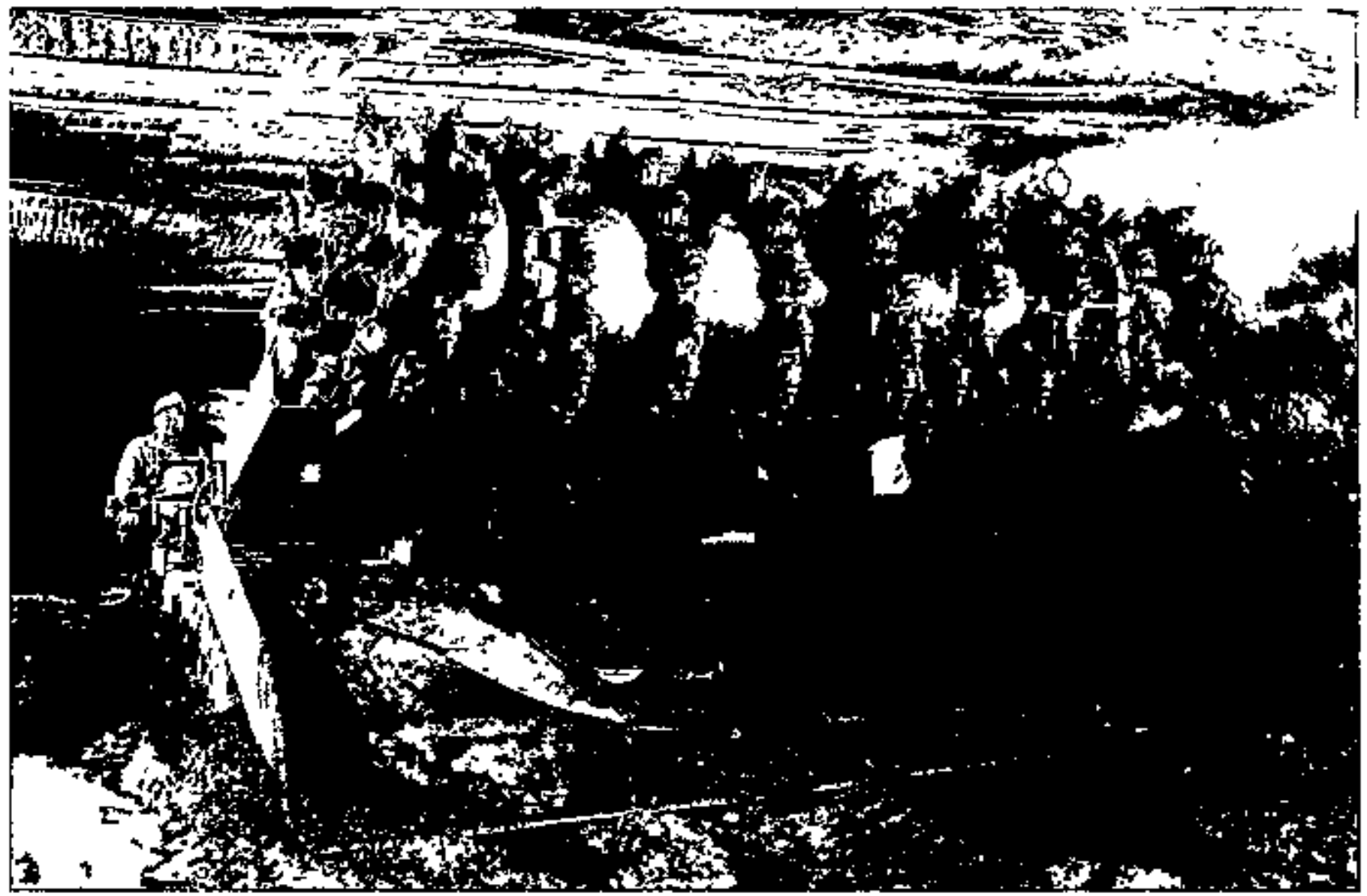

The whdly used continuous mining machine excavates coel through the use of cutting hoacts, whill the broken coal is gathered by loading ams. 


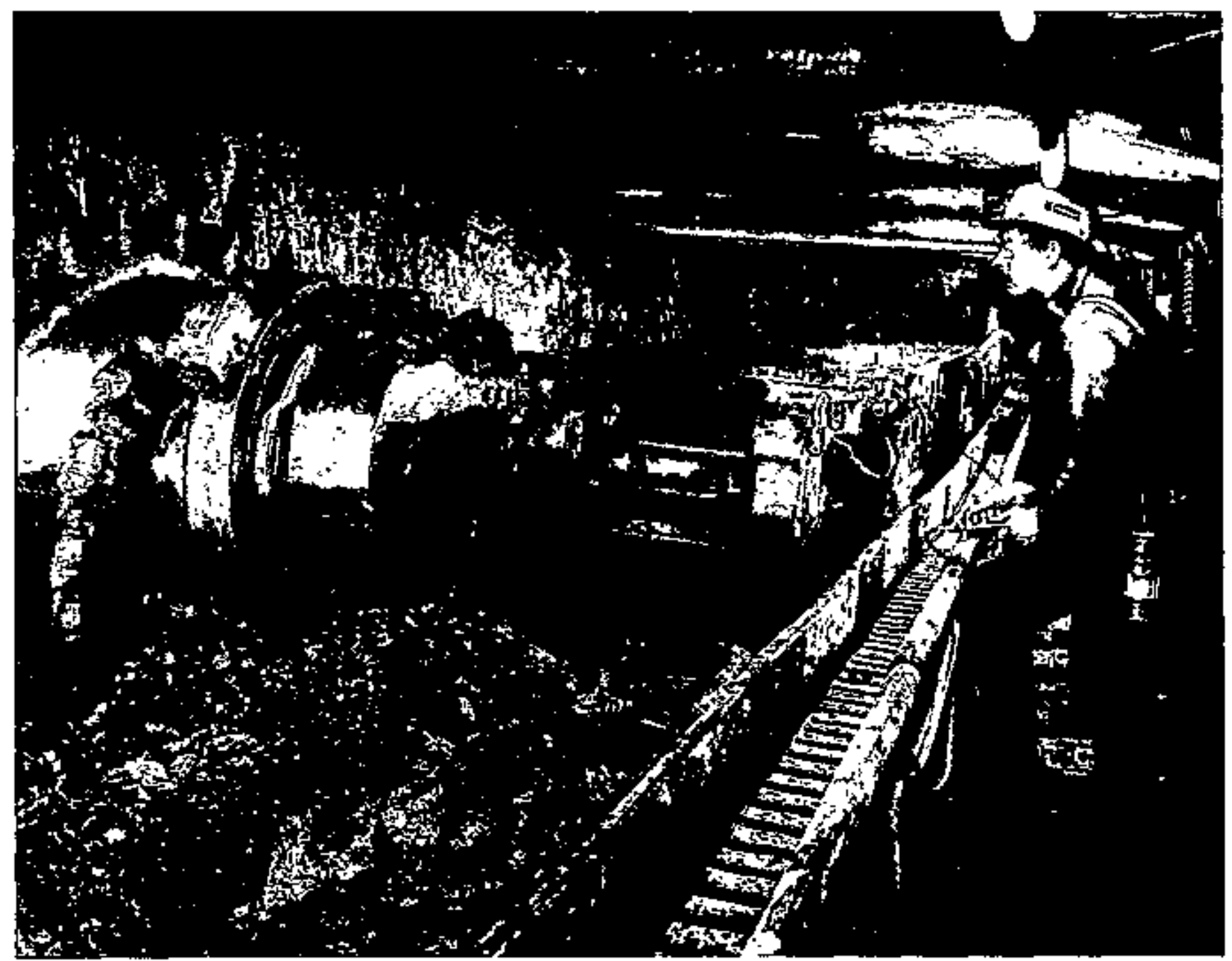

In longwall mining, a shearing mechine excavates coal as it moves back and forth achoss a coel tace hundreds of feet long.

Production of coal per shift from longwall mining generally is higher than that of either conventional or continuous mining. The longwall technique often has a better recovery rate. It is also safer because the working area is protected by overhead steel supports, coal haulage is simplified, and ventilation is better controlled. However, longwall mining has certain limitations. It is generally not suitable if the coalbed thickness varies widely or if the coalbed is broken by geologic fautits. The mine roof or floor also must be strong enough to provide a solid surface for the supports, and the mine roof must cave everly and not "Tang up." Also constraining are high capital costs for equipment and mine development.

The third techuique of underground mining is shortwall mining, used in a few mines. Shortwall mining Involves the use of a contiltuous mining machine and movable roof supports to shear coal panels 150 to 200 feet wide and more than haif a mile long. Although similar to longwall mining, shortwall mining is gererally more flexible because of the smaller working area. Productivity is lower than with longwall mining because the coal is hauled by shuttle cars rather than by conveyor.

All underground coal mining is a complex undertaking requiring the miners to use not only special machinery to cut and remove coal, but also spectial techniques such as roof bolting to prevent the mine roof from collapsing. A number of safety procedures must be followed to comply with Federal and State health and safety regulations. Entries, or passage ways, consist of at least three parallel entries, so thet if one is accidentally blocked, the others afford a means of escape. Multiple entries also provide adequate ventilation 
to carry away methane, other gases, and coal dust, with brattices and other stoppings used to direct the flow of air; they also are used to drain water from the mine-

Areas where underground mining has occurred are subject to subsidence when the mine roof collapses. Subsidence can affect buildings and other structures, and can also have hydrologic impacts, disrupting the flow of water on the surface and underground. Subsidence from longwail mining is generally more uriform and more predictable because it usually begins as coal extraction progresses. By contrast, subsidence due to room-and-pillar mining is difficult to predict because the supporting pillars deteriorate at some later time. The amount of substidence from both types of mining depend on strch factors as the depth of mining, the thickness of the coalbed extracted, and the thickness and strength of the overlying rock.

A coalled can be surface mined when it is less than 200 feet deep. Surface mining, also called strip mining, is the least expensive mining method, and sometimes it is the only safe and efficient way of mining coal at shallow depths. Surface mining is also less restrictive than underground mining, because equipment can be easity moved, although heavy equipment requires stable ground. Coal-tecovery rates at surface mines can exceed 90 percent-

Surface mining is essentially large-scale earthmoving that consists of excavating the overburden from the coalbed and then removing the coal. At some surface mines, mainly those in Appalachia, two or more coalbeds are mined during the same mining operation. The amount of overturden, or spoil, excavated per ton of coal recovered, called the overburden ratio, ranges from 1 to more than 30 cubic yards. The lower the overburden ratio, the more productive the mine. The lowest overburden tatios ate generally in the West.

Area sufface moning is practiced on flat ground and consists of a series of cuts 100 to 200 feet wide, with the overburden from one cut used to fill the mined-out area of the preceding cut (Figure 8). By comparison, contour surface mining follows a coalbed along hillsides. When contour mining becomes uneconomical, additional coal can be produced from the mine's highwall

Ffgure 8. Area Surtace Mining with Dragllne and Shovel

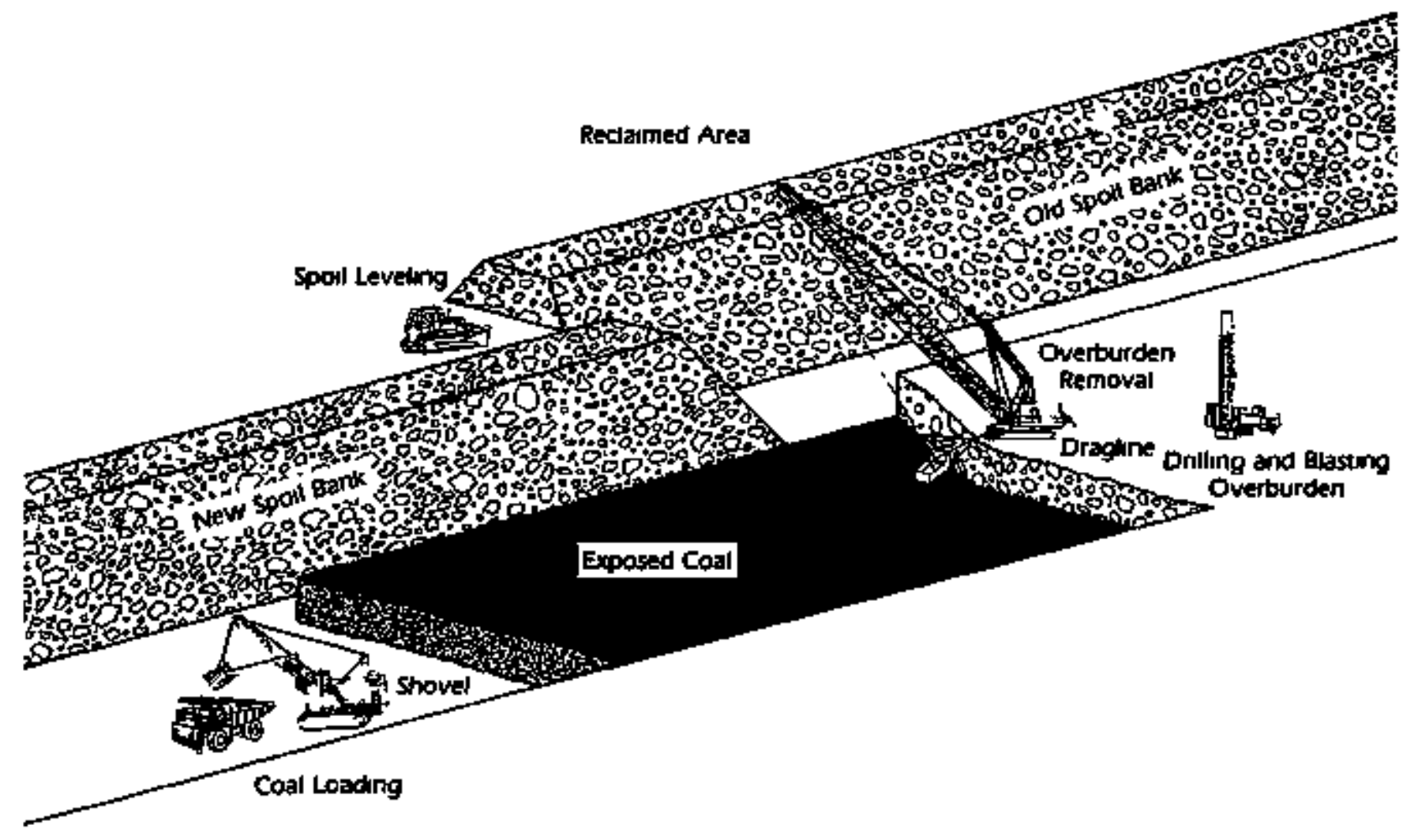

In area minhing, fong strips are excavated to concover the calal. The overturden from the strip being mined is ofposted th the strip proviousty mined. 


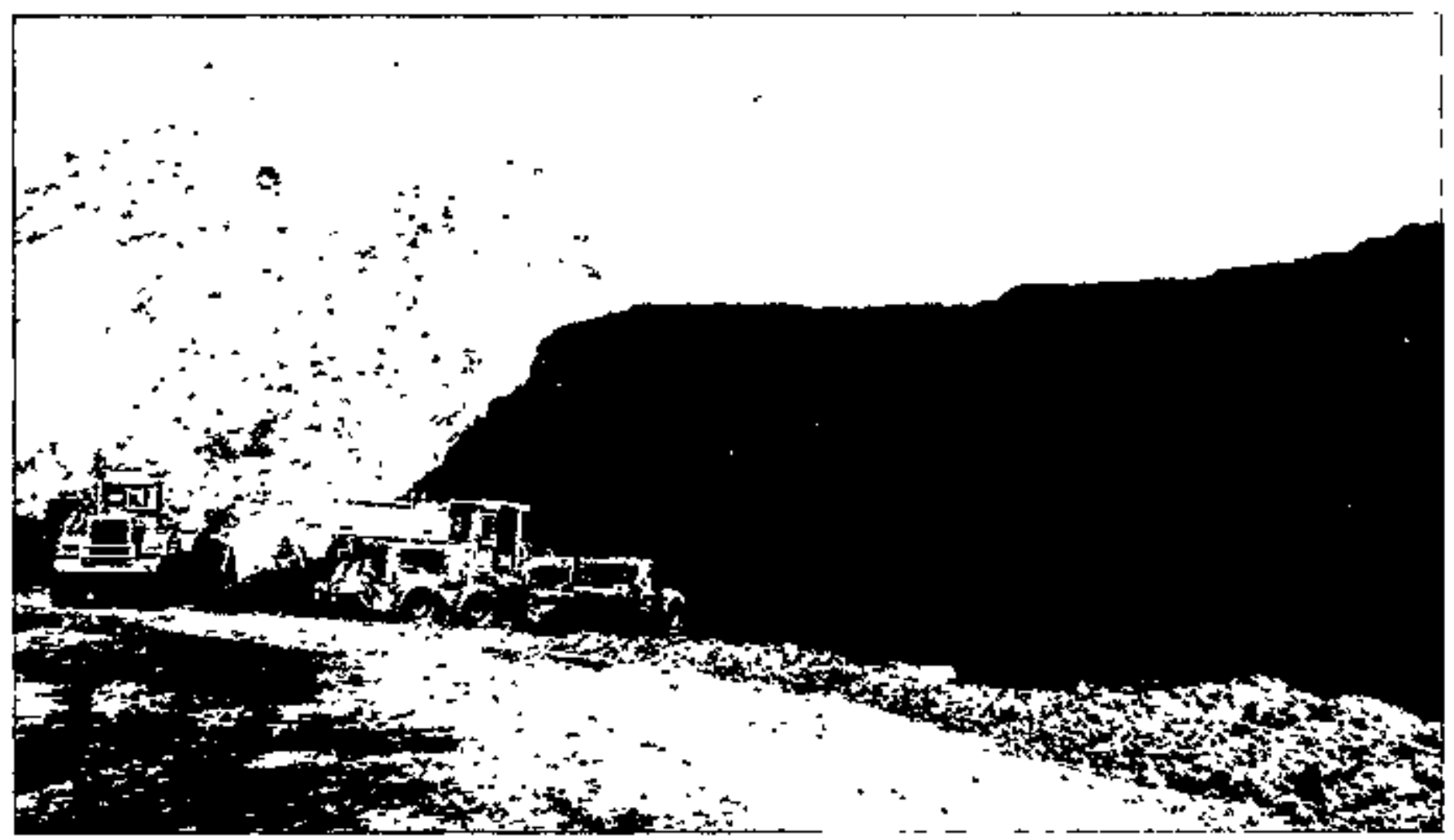

Thick coabeds that can be easily surtace mined, such as this one in Wyombing, enable a mine to activeve a high rate of productivity.

by the use of augers to drill $\mathbf{1 0 0}$ feet or more into the bed, or by opening a small drift mine called a punch minte. Open-pit mining is used where thick coalteds are steeply inclined, as in southwestem Wyoming and the anthracite area of Pensylvaria. An open-pit uine, which conbines the techniques of contour mining and area mining, can reach depths of several hundred feet The equipment used at surface mines includes dragline excavators, power shovels, hydraulic shovels, bulldozers, front-end looders, and bucketwheel excavators.

Draglines remove overburden while power shovels and hydraultc shovels load coal. However, bulldozers and front-end loaders are often used to rentove overburden in small mines; front-end loaders can also load coal. The few bucketwheel excavators in use operate in flat areas with soft overburden, such as in parts of the Midwest and Texas. Continuous surface mining machines equipped with rotating cutting heads and conveyors are used in some lignite mines.

In the anthracite area of Perrosylvaruia, surface mining trcludes the mining of culm and silt banks-waste accumulations of coal and rock from earlier tuining operations that are now being used as fuel. Another form of surface mining in parts of Appalachia is dredging, which recovers coal that was dumped into rivers from earty preparation plants or eroded from coal stockpiles or coalbeds beneath the rivers.

Because surface mining disturbs the land and can produce unstghtly areas, surface mine operators are required to reclaim mined land by restoring natural vegetation and drainage Properly reclaimed mining areas can be restored to a variety of uses, such as farmiand, wildlife areas, or parkland.

\section{Production}

Cool has been mined cormercially in the Unitted States for more than 200 years, beginuing in 1748 neat Richmond, Virginia. Westward expansion across the country stimulated local demands for coal, so that by the begirunitg of the 20th century coal was being produced in enost of the Nation's coalfields. The historical record of coal production reflects a record of industrial progress, competition from other fuels, coal miners' strikes, economic condittons, wars, enviconmental regulations, and health and safety laws.

Coal was produced in 26 Sabes in 1993, with more than half of the total output (atmost 1 billion tons) from 
three States: Wyoming, Kentuckf, and West Virininta (Table 2). Although Wyoming was the leader in tonnage produced, Kentuctsy was the leader based on the energy content of the coal produced and on the value of production.

Table 2. The 10 Leading U.S. Coal-Producing States, 1993

(Million Short Tons)

\begin{tabular}{|c|c|c|}
\hline States & Produetion & $\begin{array}{c}\text { Pareent at } \\
\text { Total }\end{array}$ \\
\hline Whaming $+\ldots+\ldots \ldots+\ldots+\ldots$ & 210.1 & 222 \\
\hline Kentucky $\ldots \ldots \ldots \ldots \ldots \ldots$ & 156.3 & t6.5 \\
\hline Whost Viginia . . . . . . . . . . . & 130.5 & โ3.8 \\
\hline Penngytvanla $\ldots \ldots \ldots+\ldots+\ldots$ & 59.7 & 6.3 \\
\hline Tosces $\ldots \ldots \ldots \ldots \ldots \ldots$ & 54.6 & S.8 \\
\hline linols $\ldots+\ldots+\ldots \ldots+\ldots \ldots+\cdots$ & 41.1 & 4.3 \\
\hline Virginie $\ldots \ldots \ldots \ldots \ldots \ldots$ & 39.3 & 4.t \\
\hline Montana $.+\ldots+\ldots \ldots+\ldots \ldots$ & 35.8 & $\mathbf{3 . 8}$ \\
\hline 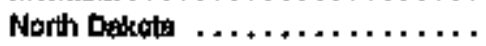 & a2.0 & $\mathbf{3 . 4}$ \\
\hline todiana $\ldots \ldots \ldots \ldots \ldots \ldots$ & 29.3 & 3.1 \\
\hline Total $\ldots \ldots \ldots \ldots \ldots \ldots \ldots \ldots$ & 7eg.8 & 83.4 \\
\hline U.8. Total & 945.4 & 100.0 \\
\hline
\end{tabular}

Source: Eneryy mlomalton Adminisiration, Cod indusiny Anmuat IOS9, DOESEIA-0594(98) (Washington, DC, Decembar 1994).

About 60 percent of the coal produced was bituminous coal, historically the predominant rank. Most of the balance was subbituminous coal and lignite, both of which have been produced in increasingly larger quantities since 1970 to satisfy the demand for ubility coal. The share of total production from subbituminous coal has risen from 4 percent in 1970 to 29 percent in 1993, and that from lignite has risen from less than 2 percent to 9 percent. By contrast, anthractte production, which accoumted for less than 1 percent of the 1993 total, has been declining for several decades because of competition from other furels and difficult mining conditions, which keep the price of anthracite relatively high. Internationally, the 1993 U.S. coal output was estimated to rank Becond to China among the more than 50 coal-producing countries.

Historically, arunal coal production, fueling industrial development, reached 200 million tons before 1900 (Figure 9). It then citmbed to more than 600 million tons before declining during the Depression years. Production increased during World War II and peaked at nearty 700 million tons in 1947, before trending downward in the postwar years as coal markets were lost to low-cost oll and natural gas. Not only was oil easier and cleaner to handle, with low-cost oil imports supplementing the domestic supply, but long-distance pipelines were built to bring natural gas from the Southwest to eastern markets, where its convenience of w5e cut sharply into the market for coal for home heating and other uses. Coal was also confronted with another rival in the utility market-the development of nuclear generabed electricity. Further hampering the use of utility conl was a growth in hydroelectric power. As the market for coal weakened, coal production dropped from more than 500 million tons in the 1950 's to a little more than 400 million tons in the earty 1960 's, although it rose from time to time mostly because of increased exports.

In the 1970's, however, coal production once again rose. Following the Arab oil embargo, which disrupted the

Figure 9. U.S. Coal Production, 1890-1993

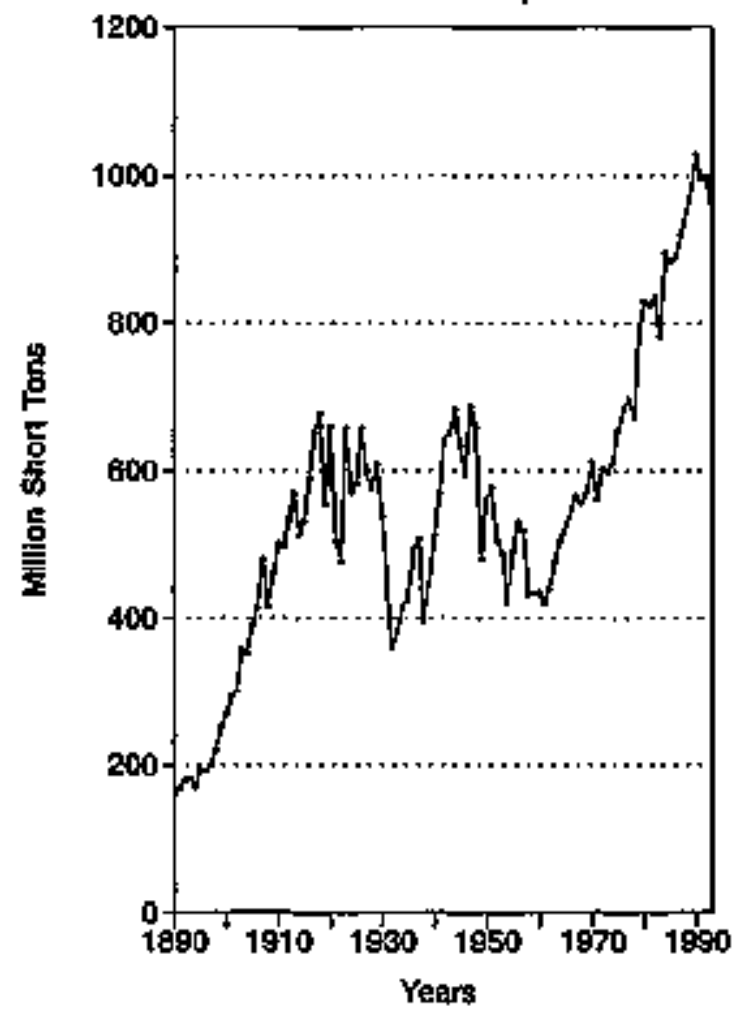

The trend of U.S. coal production reflents comperition from other energy sounces, economic conolitions, strikes end wars. The rise since 1960 is dus to increased use of cosil to generate electricity.

Sources: Energy knormation Adminisiralion, State Coal Profiles, DOEJEIA-0576 (Washington, DC, Jamuary 1994), end Coal industry Annusl 1983, DOEIEA-0584(93) (Washington, DC, December 1994). 
supply of foreign oil and sharply increased oil prices, interest was renewed in the largely unused domestic coal reserves as a way of reducing dependence on foreign oil. In addition, the enactment of clean air standards spurced the opening of large mines in the West to supply low-sulfur coal for electric utilities. As the caal market improved and new mines opened, coal production expanded to record levels, surpassing 800 million tons in 1980 and I billion tons in 1990, dropping only slightly since then. In the last two decades, the coal output from many States reached an all-time high (Table 3). The upward trend for coal production,

Table 3. Peak Year of U.S. Coal Production by State, Through 1993

(Thousand Shot Tons)

\begin{tabular}{|c|c|c|}
\hline State & Yoar & Pradtuction \\
\hline Alabama $\ldots \ldots \ldots \ldots \ldots$ & 1990 & 28,030 \\
\hline Alaska $\ldots \ldots \ldots \ldots \ldots$ & 1986 & 1,745 \\
\hline Atizona $\ldots \ldots \ldots \ldots$ & 1991 & 58,203 \\
\hline Arkanstas $\ldots \ldots \ldots \ldots$ & 1907 & 2,670 \\
\hline California . . . . . . . . . . & 1880 & 287 \\
\hline Colorado $\ldots \ldots \ldots \ldots \ldots$ & 1993 & 21,886 \\
\hline Georgia .............. & 1908 & 417 \\
\hline lilinois $\ldots \ldots \ldots \ldots \ldots$ & 1918 & $89,29 t$ \\
\hline indleng $\ldots \ldots \ldots \ldots \ldots$ & 1984 & 37,555 \\
\hline lowa $\ldots \ldots \ldots \ldots \ldots$ & 1917 & 8,966 \\
\hline Kenseds,$\ldots \ldots \ldots \ldots$ & 1918 & 7,562 \\
\hline Kentucky $\ldots \ldots \ldots \ldots \ldots$ & 1990 & 173,302 \\
\hline Lorisiang . . . . . . . . . . . . & 1992 & 3,240 \\
\hline Marytand ............ & 1907 & 5,533 \\
\hline Mathigan $\ldots \ldots \ldots \ldots \ldots$ & 1907 & $\mathbf{2}, 036$ \\
\hline Missouri ............. & 1984 & 6,733 \\
\hline Montana . . . . . . . . . & 1992 & 38,$8 ; 9$ \\
\hline Nem Wexlco $\ldots \ldots \ldots \ldots$ & 1999 & 28,268 \\
\hline North Caralina $\ldots \ldots \ldots$. & 1922 & 79 \\
\hline North Dakota $\ldots \ldots \ldots \ldots$ & 1998 & 91,973 \\
\hline Qhlo .............. & 1970 & 55,351 \\
\hline Oklahoma......... & 1970 & 6,070 \\
\hline Oregon $\ldots \ldots \ldots \ldots$. & 1904 & 112 \\
\hline Pemsytrania $\ldots \ldots \ldots$. & 1918 & $2 \pi, 377$ \\
\hline Anthracte $\ldots \ldots \ldots \ldots$ & 1817 & 99,612 \\
\hline Eltumhouss $\ldots \ldots \ldots \ldots$ & 1918 & 176,551 \\
\hline Soulh Dakota . . . . . . . . & 1941 & 71 \\
\hline Tennessee $\ldots . . . \ldots \ldots$ & 1972 & 11,260 \\
\hline Texes $\ldots \ldots \ldots \ldots \ldots$. & 1990 & 55,755 \\
\hline Utah $\ldots \ldots \ldots \ldots \ldots$. & 1990 & 22,058 \\
\hline Virginia $\ldots \ldots \ldots \ldots$ & 1990 & 46,017 \\
\hline Washington $\ldots \ldots \ldots \ldots$ & 1992 & 5,251 \\
\hline West Viginia $\ldots \ldots \ldots$ & 1847 & $17 b, 157$ \\
\hline Wyoming $\ldots+\ldots+\ldots+\ldots$ & 1993 & 210,129 \\
\hline U.S. Total . . . . . . . . . . & 1990 & $1,029,076$ \\
\hline
\end{tabular}

Sounces: U.S. Department of the Interlor, Bureau of Mines, Minerals Yearook verious lsoutes, and Energy Informetion Adiminisuation, COE' Proctuation, COEJELA-0118, various ksues; and Coal indesisy Amnuel 1993, DOEELA-0594(93) (Wachington, DC, Oecember 1994). despite several coal miners' strikes, was in notable contrast with the generally declining production trends (oased on total Btu content) for domestic crude oil and nahural gas. Cumulative U.S. coal production from 1890 fhrough 1993 is about 58 billion tons (Table 4).

\section{Table 4. Cumulative Coal Production by State, t890-1993 (Bllion Shorl Tons)}

\begin{tabular}{|c|c|c|}
\hline states & Prodtuclion & $\begin{array}{c}\text { Percent of } \\
\text { Total }\end{array}$ \\
\hline Pennsymania,$\ldots \ldots \ldots \ldots \ldots$. & ${ }^{*} 15.3$ & 26.3 \\
\hline West Vrgining $\ldots \ldots \ldots \ldots \ldots \ldots$ & 10.8 & 18.5 \\
\hline Kenttecky $\ldots \ldots+\ldots \ldots \ldots \ldots$ & 7.1 & 12.2 \\
\hline |innols $\ldots \ldots \ldots \ldots \ldots \ldots \ldots \ldots$ & 5.6 & 9.6 \\
\hline Ohlo $\ldots \ldots \ldots \ldots \ldots \ldots \ldots$ & 3.5 & 6.0 \\
\hline Wyorning $\ldots \ldots \ldots \ldots+\ldots \ldots+$ & 2.9 & 5.0 \\
\hline Indlana $\ldots+\ldots+\ldots+\ldots+\ldots+\ldots$ & 2.1 & 3.6. \\
\hline Vinginia $\ldots \ldots \ldots \ldots \ldots$ & 2.0 & 3.5 \\
\hline Alabama $\ldots \ldots \ldots \ldots \ldots \ldots$ & 1.9 & 3.2 \\
\hline Other Statrs $\ldots \ldots \ldots \ldots \ldots \ldots$ & 7.1 & 12.2 \\
\hline Total & 58.1 & 100.0 \\
\hline
\end{tabular}

"includes 10.7 bilion short kms of bituminous coal and 4.6 billion short tons of andwracte.

Source: U.S. Depertunent of the Interior, Bureas of hines,

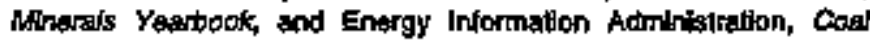
Production, DOEEIA-0118, varlous lesues; and Cos induginy Ariusal 7983, DOETEA-0594(93) (Wastington. DC, December 1994).

The high level of coal production was accompanied by shifts in both the geographic distribution of coal production and in the share of coal produced by surface mining. In 1970, most of the coal was mined east of the Mississippl River, principally from the Appalachian Region. By 1993, however, the share of production from eastem coal mines was only about 55 percent, while the rest was from westem mines. Equally significant, sur face mines gatned a larger proportion of production, about 60 percent in 1993 as opposed to 44 percent in 1970, most of it in the West.

The major share of the additional coal production has been from leases on federally administered lands, principally Federal lands but also Indian lands. Coal production from Federal leases-the fastest-growing segment of U.S. coal production-has risen from 7 million tons in 1970, when it accounted for about 1 percent of the U.S. total, to 258 million tons in 1993, when it comprised 30 percent, due chiefly to highly productive leases in Wyoming. During the same period, the coal output from leases on Indian lands increased from 5 millton to 28 million tons. Indian coal leases 


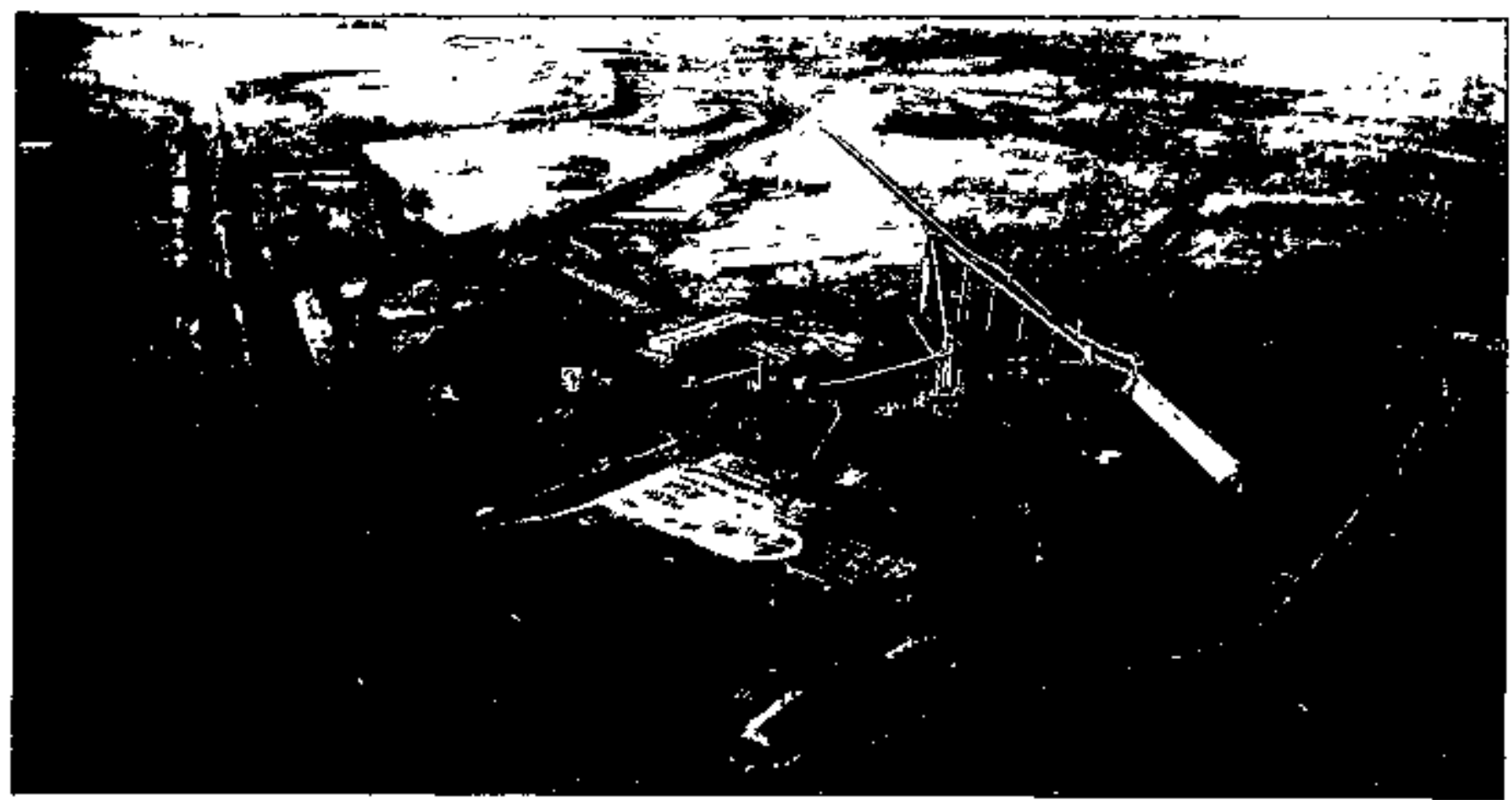

Wyouning's Black Thunder surface mine, shown here, is the Nation's lergest coal mithe. its 1993 output of 34 millian short tons was more than the entive production of many States.

leases are on the tribal lands of the Navajo and Hopi in Arizona, the Navajo in New Mexico, and the Crow in Montana. They are administered by the U.S. Department of the Interior's Bureau of Indian Affatrs. Coal sales from Federal coal leases generate substantial royalites (\$265 million in 1993) that are distributed to the U.S. Deparment of the Treasury and to the States in which the leases are located. Royalties from Indian coal sales ( $\$ 65$ million) are disbursed to the tribal governments and Indian allotment owners.

The large amount of coal currently produced is from fewer but larger mines than in the past. The 1993 coal output, for example, was from about 2,500 mines, whereas in 1970 about 6,000 mines produced 40 percent less coal, The greater output from today's coal mines is due to advances in mechanization that brought continuous mining machines and longwall mtring systems to underground mines and largecapacity power shovels, draglines, and coal-hauling equipment to surface mines. In 1970, mines with an armual output of move than 500,000 tons represented about 5 percent of the total number of mines and accounted for almost 60 percent of total coal production. By comparison, in 1993 this category of mines represented 14 percent of the total number, but supplied more than three-fourths of a considerably larger output In addition, nearly 200 mines in 1993 produced at a level of 1 million tons or more, together accounting for two-thirds of the total coal mined. Of the 10 leating U.S. coal mines in 1993, 8 were surface mines in Wyoming. The largest surface coal intne was the Black Thunder, which was operated by ARCO Coal Company in Wyoming's Powder River Basin; it produced 34 million tons-more coal than was mined in 18 States. The largest underground coal production, 7 million tons, was from the EnJow Fork Mine of Consol Energy, Irc., in Pennsylvania.

Parallefing the trend of increasing mine size, coalproducirg companies have also become larger. This has occurred because the mechanization of mines requires larger copital investments. Some small coal companies, lacking the finencial resounces to continue independently, have merged with other coal comparies; however, many small mining companies have closed. In addltion, some large coal consumers, such as electric utillties, have acquired interests in coal mining companies in order to secure long-term coal supplies. Some petroleum companies have expanded their interest in energy by acquiring shares in coat-producing companies.

Because the bigger coal companies generalty operate a number of large mines, often in different States, they have gained a greater share of total production. In the mid-1950/s, for example, the 10 largest coal companies 
produced about one-thitd of the Nation's coal output. In 1993, with production at a much greater level, the top 10 coal companies accounted for more than 40 percent of the output (Table 5). Although foreign comparies have interests in U.S. comparies, the coal industry is predominantly controlled by donestic comparies. Currently the top three coal-ptoducing companies are the Peabody Holding Company, which is controlled by Hansen PLC, a British firm; Cyprus Minerals, a U.S. company; and Consolidation Coal Company, which is affiliated with Du Pont/Rheinbraun AG, which represents U.S., Canadian, and German interests. In 1993, these three companies together were responsible for about one-fith of the total U.S. coal output.

\begin{tabular}{|c|c|c|}
\hline Compeny & Production & $\begin{array}{l}\text { Percent of } \\
\text { Total } \\
\text { Production }\end{array}$ \\
\hline Pagbody Hotding CD., wo. . . . . . . & 69.7 & 7.4 \\
\hline Cypus Minera's Co. ............ & 65.3 & 69 \\
\hline Consol Eneryy, he. $\ldots \ldots \ldots \ldots$ & 50.7 & 5.4 \\
\hline Znigles Cogal Hotding Co. $\ldots \ldots \ldots \ldots$ & 37.5 & 4.0 \\
\hline ARCO $\mathrm{Cod}$ CO. $\ldots \ldots \ldots+\ldots \ldots$ & 97,4 & 4,0 \\
\hline Kerreopott Energyy co. $\ldots \ldots \ldots \ldots$ & 36.7 & 3.9 \\
\hline Exoon Coal USA Ine. $\ldots \ldots \ldots \ldots$ & 28.1 & 3.0 \\
\hline Texes Utillies Co. $\ldots \ldots \ldots \ldots \ldots$. & 27.6 & 2.9 \\
\hline Montana Power Co. $\ldots \ldots+\ldots+\ldots+$. & 26.4 & 2.8 \\
\hline North Armarlean Capl Copp. $\ldots \ldots+\ldots$ & 26.3 & 2.8 \\
\hline rotes $\ldots \ldots \ldots \ldots \ldots \ldots \ldots \ldots$ & 405.6 & $\$ 0$ \\
\hline U.s. Total $\ldots, \ldots, \ldots, \ldots, \ldots, \ldots$ & 945.4 & 100,0 \\
\hline
\end{tabular}

Notr: Toteds may not equad sum of components becanse of independent rounding.

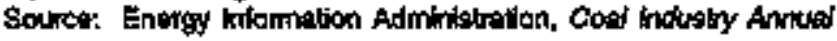
1993, DOEEIA-0584(93) (Washington, DC, Dederuber 1984).

\section{Quality of Coal Production}

If coal were a uniform product, it could be used with fewer problems. However, its composition varies significantly. Although characteristics such as fixed carton, volabile matter, grindability, ash-fusion temperature, and coking ability have long been important in using and marketing coal, the heat vahe and the percentage of sulfur and ash, by weight, are of special interest the heat value indicates how much energy is purchased per dollar. The sulfur content is an environmental concern because sulfur dioxide, a pollutant, is emitted when coal is bumed. The ash content represents the incombustible material that can be emitted as particulate matter and also contributes to the erosion of boiler components.

The average heat value of coal is highest in the East, where virtually all of the coal is bituminous in rank, and relatively low for coal in the West, which has large deposits of subbituminous coal and lignite. Although anrual coal production has increased, the total heak content of production has not risen at the same rate because of the greater amounts of low-rank coal mined for electric utilities. For example, in 1970, the average heat value of the 613 million tons of coal produced was 23.8 million Btu per ton, resulting in energy production of 14.6 quadrilltion Btu. By comparison, the 1993 production was nearly 1 billion tons, more than 50 percent larger, but the energy value was 20.2 quadritlion Btu, only about 38 percent higher, because the average heat value of the coal declined to 21.4 million Btu per ton. For ubility coal, the average heat content dropped from 22.6 million Btu per short ton in 1970 to 20.6 milltion Btu in 1993, whereas the estimated heat content of coking coal was relatively constant during the period, averaging 26.8 million Btu per short ton arrually. Coal consumed by other industrial users declined slightly in heat valuse, from 23.0 million Btu per short ton in 1970 to 22.2 million Btu in 1993. The small amount of coal used by residential and commercial consumers fluxtuated between an estimated 22.2 million and 23.7 mittion But per short ton during the period.

The average sulfur content of coal production, based on utility coal production, has been declining because of the langer amounts of low-sulfur coal from the West. Over the 1973-1993 period, the average sulfur content (by weight) of utility coal fell from 2.3 percent to 1.2 percent. Similarly, the average ash content (by weight) of utility coal also decreased over the period, dropping from 13.0 percent to 9.5 percent, due to the greater use of Wyoming utility coal, which has a relatively low ash content. Coal for industrial use in $\mathbf{1 9 9 3}$ contained an average of 2.5 percent sulfur and 13.5 percent ash.

\section{Coal Prices}

In general, coal is the least expensive domestic fossil fuel produced, based on its heat content. Coal is about one-thtrd as expensive as crude oil and neariy half as costly as natural gas. Wher adjusted for inflation, the average price of coal in 1993 (about $\$ 20$ per ton) was about 44 percent lower than it was a decade earlier and less than half of the price in the mid 1970's. The highest price of coal in "real" dollans (adjusted for inflation and expressed in 1987 dollars) was $\$ 39$ per ton in 1975 , which amounted to $\$ 19$ per short ton in current dollars 
and was the restlt of the oil embargo in 1973-74. The embargo caused a sharp rise in oil prices, and coal prices also rose mainly because producers expected a rapid and widespread switch from oil to caal Coal prices reached $\$ 27$ per ton in 1982 (real price of $\$ 32$ per ton) before falling as the price of oil declined and the conversion from oil to coal slowed.

The price of coal varies by coal rank, mining method, geographic region, and coal quality. Surface-mined coal is genenally lower-priced than underground-mined coal. Whate coalbeds are thick and near the surface, as in Wyoming, mining costs and, therefore, coal prices tend to be lower than where the beds are thinner and deeper, as in Appalachia. The higher cost of coal from urderground mines reflects the more difficult mining conditions and the need for more miners. Coals with a high heat content are generally higher priced. Lowsulfur coals can command a higher price than highstulfur coals. The average price per ton of coal in 1993 was about $\$ 9$ for subbikuminous coal, $\$ 11$ for lignite, $\$ 26$ for bituminous coal, and $\$ 3$ for anthracite.

Transportation costs add significantly to the delivered ptice of coal. In some cases, as in long-distance shipments of Wyoming coal, transportation costs can be more than the price of coal at the mine. The average delivered price of coal shipped to electric utilities, the major coal consumets, reached highs in the early 1980's of about $\$ 5$ per ton (real price of about $\$ 39$ per ton). Since then, the average delivered price of utiliky coal has generally declined, dropping in 1993 to about $\$ 29$ per ton (real price of $\$ 24$ per ton).

\section{Employment, Productivity, and Earnings}

The number of workers employed in the coal industry has declined so precipltousiy that the size of the coal mining labor force today is less than one-third the size it was a century ago-despite recond levels of coal production. In contrast to a range of 400,000 to 800,000 workers employed in coal mining from 1900 to 1950 , the number was around 100,000 in 1993. About 6,000 women were employed by the coal industry in production and other work. Before 1973, government records showed no women coal miners, reflecting biases and superstitions, such as the belief that women brought bad luck into the mine. By 1979, however, their ranks had grown to about 2,600, and in 1982 , employment of women corl miners peaked at 11,600. The rise was spurred by the 1964 Civil Rights Act, a 1965 Executive order barring discrinination in employ- ment and requiting afirmative action plans for businesses receiving Federal contracts, and a 1978 U.S. Department of Labot training program for women who wanted to begin coal-mining careers.

The drop in the size of the total coal mining workforce has been due to the replacement of manual labor by machines in vintually every phase of mining. At underground mines, the improvement of equipmeat and the introduction of remote-controlled mining and roofbolting and other inoovations have reduced crew sizes while improving safety and productivity. At serface mines, operations have speeded up and the number of employees has dropped through the use of larger and faster excavating and trangorting equipment and improved blasting techniques. Af both types of mines, computers have become an integral patt of mine planning and operations and are also having a positive influence on productivity.

The greatest lass of miners has been in the coalfields in Appalactia, where the number has been reduced by more than half since 1980, falling from 171,000 to 71,000 in 1993. Nevertheless, Appalachia continues to be the center of the U.S. coal mining workforce, with about 7 out of every 10 U.S. coal miners in 1993. Nearly half of the coal miners worked in Kentucky and West Virginta (Table 6).

Table 6. The 10 Leading Btates in U.\$. Coal Mine Employment, 1993

\begin{tabular}{|c|c|c|}
\hline stute & $\begin{array}{l}\text { Average } \\
\text { Number } \\
\text { of tillows: }\end{array}$ & $\begin{array}{c}\text { Percent of } \\
\text { Total }\end{array}$ \\
\hline Kentugeky $+\ldots+\ldots \ldots+\ldots+\ldots+\ldots$ & 24,063 & 23.7 \\
\hline Whost vighta $\ldots \ldots \ldots \ldots \ldots \ldots$ & 22,979 & 227 \\
\hline Pennsynasla $\ldots \ldots \ldots \ldots \ldots \ldots$ & 10,940 & 10. \\
\hline vinginta $\ldots \ldots \ldots \ldots \ldots \ldots \ldots$, & 0,339 & 82 \\
\hline blpols $\ldots \ldots+\ldots \ldots+\ldots \ldots+\ldots$ & $7,3 \infty 0$ & 72 \\
\hline Alabama $\ldots \ldots \ldots \ldots \ldots \ldots$ & 5,399 & 5.5 \\
\hline Ohto $\ldots \ldots \ldots \ldots \ldots+\ldots \ldots+\ldots$ & 8,866 & 30 \\
\hline Indiana $\ldots \ldots+\ldots \ldots \ldots \ldots$ & 3,331 & 3.0 \\
\hline whyoming $\ldots \ldots \ldots \ldots \ldots \ldots \ldots$ & 3,100 & 3.1 \\
\hline Texpos $+\ldots \ldots+\cdots+\ldots+\cdots+\ldots$, & 1,841 & 1.8 \\
\hline Total $\ldots \ldots \ldots \ldots \ldots \ldots \ldots \ldots \ldots$ & 91,220 & 90.0 \\
\hline Us. Total $\ldots \ldots \ldots \ldots \ldots \ldots \ldots \ldots$ & $101,32 x$ & 100.0 \\
\hline
\end{tabular}

Noto: Average number working daly. Inchudes employeas engaged in proxduction, preppesalion, processting, dovolopment, matintananea, sepalr, shop of yeard woik at mining operaltors. Exciudes office workers and minos produsing less then 10,000 short cons of coal duting the year and proparation plents with lese than 6,000 enploghe hourt.

Sounce; Enargy Intomalion Administralion, Coad industry Annuaf 1893, DOEEIA.06s4(9S) (Washington, DC, December 1994). 


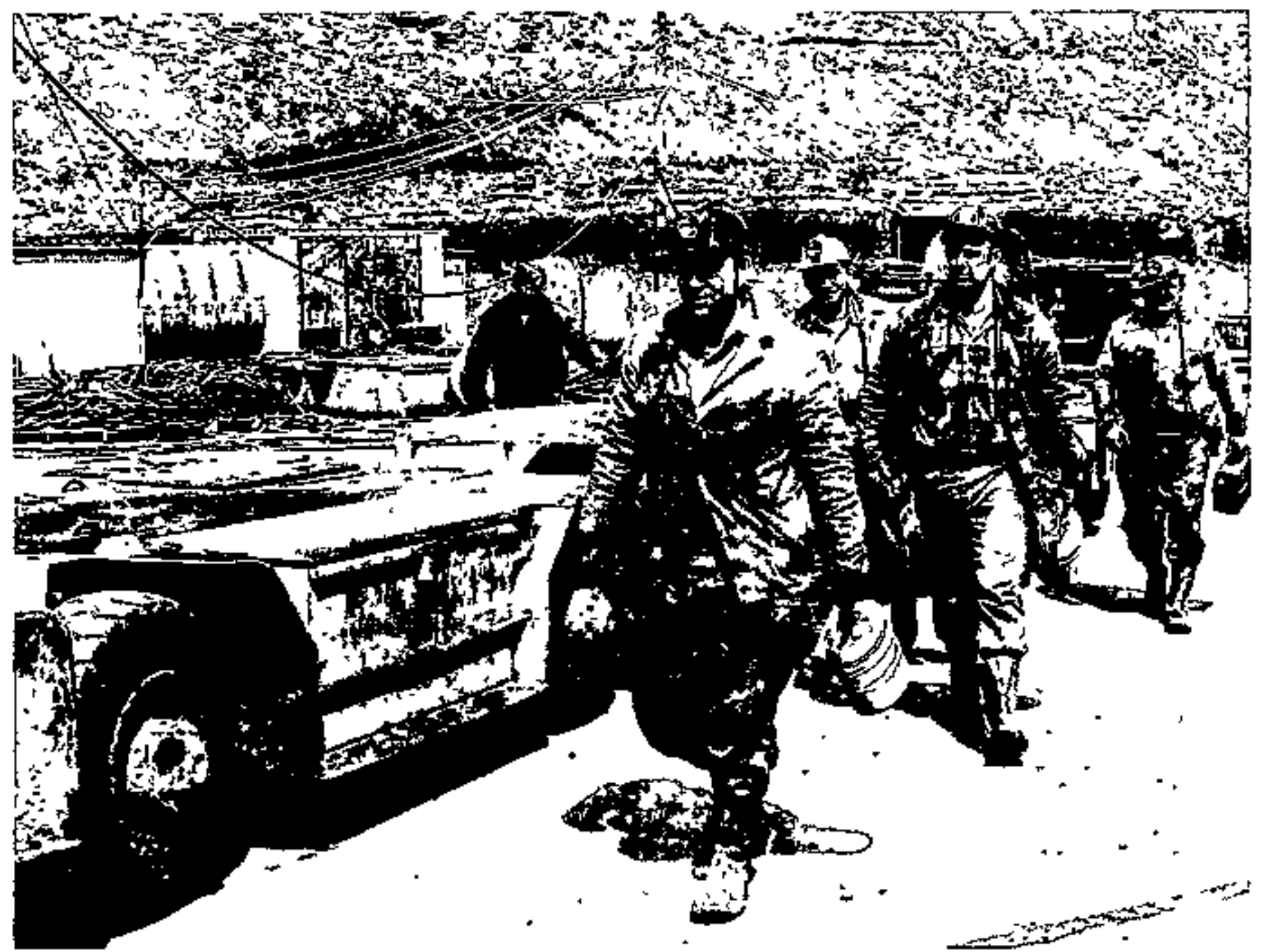

About ro0,000 coal miner were employed in 1933. On average, they produced 6 short tons of cast per hours eaming $\$ 17$ per hour.

Although coal mine employment has fallen, overall productivity in the U.S. coal industry has reached record levels. Productivity to 1993 was nearly 5 tons per miner per hour, almost six times higher than in 1950, due mostly to a higher tate at surface mines. Productivity at surface mines has consistently been higher than at underground mines, primarity because fewer workers are required. Productivity rose from about 2 tons per miner hour in the 1950's to a peak of nearly 5 tons per miner hour in 1974, dropped to about 3 tons in 1978, and since then steadily grew io 7 tons in 1993. The decline in 1978 was dine to several factors. One was the opening of smaller, less effirient mines (often worked by younger, inexperienced miners) in response to rising coal prices dite to the oil embargo in the early 1970's. Many of these mines later closed when the price of coal dropped and mining became uneconomical Another factor that initially depressed surface mining productivity was the enactment of the
Federal Surface Mining and Reclamation Act of 1977 and State reclamatton laws, which require restoration of mined land, thereby diverting some employees and equipment from production activities. Factors that have been significant in raising the average productivity at surface mines are increases in the size and power of surface mining equipment and the large-scale mining of very thick coalbeds in the West.

In underground mines, improvements in productivity have been less dramatic As recently as the early $1950^{\prime} \mathrm{s}$, underground miners averaged less than 1 ton per hour. The rate approached 2 tons per hour when the Federal Coal Mine Health and Safety Act of 1969 imposed many new safety regulations (such as the need to stop work between conl cuts to install roof supports). These initfally hampered underground productivity, which fell to a low point of about 1 ton per miner hour in 1978. However, the regulations became less of a 
constraint as miners learned to adapt to the changes without compromising safety. As with surface mines, productivity was also hampered by the opening of many small, less efficient mines in response to rising coal prices and rising demand due to the oil embargo, mines that later became ureconomical and closed. Also taking their toll on productivity in the 1970's were several major coal miners' strikes by the United Mine Workers of America. However, by 1993 underground productivity reached nearly 3 tons per miner hour, reflecting the greater use of continuous-mining machines and longwall mining.

Coal miners, in general, are the highest paid workers in the mining industry, including oil and gas extraction; their wages are above the average paid in the steel, automobile, and chemical industries, according to the US. Department of Labor. In 1993, coal mine production workers averaged $\$ 765,90$ per week (in current dollars), or $\$ 17.25$ per hour, working an average of 44.4 hours. A decade earlier they eamed $\$ 54.83$ per week (current dollars), or \$13.73 per hour, for 39.9 hours.

\section{Health and Safety}

Coal mining, particularfy underground coal mining, historically has been a dangercus occupation, but the risk has been reduced dramatically. In recent years, the injury incidence rate for coal mining has been generally below that in mary sectors of the construction and manufacturing industries, according to the US. Burear of Labor Statistics.

The Federal Government has been involved in mine safety since 1910, when Congress established the Bureau of Mines as a research and fact-finding agency on coal mining. In 1941, Congress authorized Pederal inspection-but not regulation - of coal mines, After 119 miners were killed in a coal mine explosion in West Frankfort, Irinois, in 1951, Congress enacted the Federal Coal Mine Safety Act of 1952, which increased the Bureats's inspection authority and empowered it to close underground mines engaged in interstate commerce that did not follow mandatory safety standards for underground coal mines; surface mines and underground mines operations employing fewer than 15 workers were exempted. The Federal Coal Mine Health and Safety Act of 1969 vastly increased the Goverment's enforcement powers by covering vir tuaily every aspect of coal mining and by mandating fines for violations, authorizing criminal penalties for intentional violations, and enabling miners to request safety inspections. In addition to imposing mandatory safety training, the new law requires coal-mine operators to have plans for ventilation, roof support. and emergency evacuation approved by the Mining Enforcement and Safety Administration (MESA). MESA was created in 1973 in the U.S. Deparment of the Interior to handle mine inspections previously perforted by the Bureau of Mines. It is the predecessor of today's Mire Safety and Health Administration (MSHA), formed in 1978 as part of the U.S. Department of Labor. MSHA is required to inspect underground coal mines four times per year and surface coal mines two tiutes per year. It has the authority to issue cilations and stop mining operations when conditions are dangerous.

As a result of more stringent safety regulations, mechanization, and roof bolting, the record for mine safety has greatly improved. In 1993, cool mining claimed 47 lives. In the $1980^{\circ} s$ an average of 79 coal miners lost their lives each year, whereas in the 1970's, the toll averaged 129. The worst year in the history of coal mining was 1907, when 3,242 miners perished.

Explosions of coalbed methane and coal dust, which are ignited by a flame or spark, cause the major coal mine disasters and claim the greatest number of lives where coal is mined underground. In the United States, the ftrst reported coal mine explosion occurred around 1810 near Rtchmond, Virginita. The worst U.S. coal mine disaster, taking the lives of 362 miners, was due to an explosion at Monongah, West Virginia, in December 1907. Mine 5afety regulations and practices have markedly reduced the danger of explosions by requiring sufficient mine ventllation to prevent the accumulation of high levels of methane and coal dust in the mine atmosphere. Coal dust is also controlled by making it noncombustible through the use of watexsprays and by "xockdusting" mine areas with puiverized limestone or similar noncombustible material Other safely measures include the use of explosives and electrical equifpment that have passed certain safety tests and are formally approved as "permissible" by MSHA.

Historically, winter is the most hazardous time for coal mine explasions. From October through March, MSHA snotifies underground coal miners of a "Winter Alert," warning them that methane and coal dust explosions are more likely to occur during this period than at any other time of the year. Hazards increase because dry winter air entering a mine becomes warm and absorbs moisture from the mine workings. As the mine "dries out," more coal dust becomes suspender in the mine air, increasing the risk of ignition In addition, a sudden drop of barometric pressure causes methane to expand and flow from inactive areas of the mine to areas where the miners are working. 


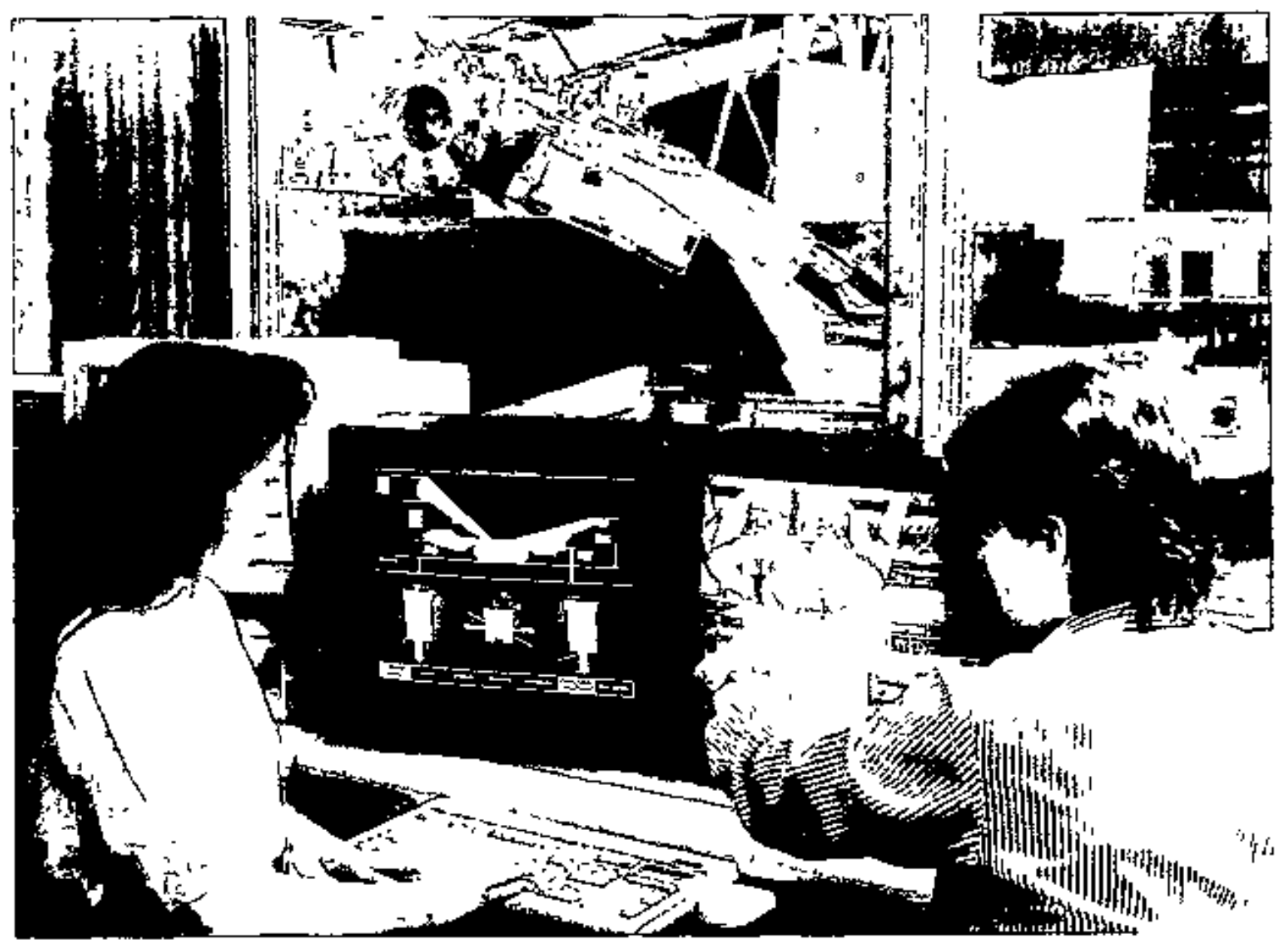

Mining reseerch includes the development of technology that will enable a miner to be bavted in a safe place while using a computer to control a mining machina.

Although explosions are responsible for the most dramatic disasters in underground coal mines, roof falls historically have been the single most frequent cause of fatal accidents in U.S. coal mines. Roof falls occur when part of the mine roof or rib (stde) breaks away. Usually this occurs within 25 feet of the working face, before the area is permanently supported. More roof fall fatalities occur wtth the room-and-płllar mining method than with longwall mining. Fatalities at surface mines are targely caused by falls of rock from the side of the mine and accidents involvtng machinery. Haulagerelated accidents generally rank second as the cause of coal mine fatalities.

Apart from accidents, coal miners also face the danger of contracting coal workers pneumoconiosis, or "black lung." the consequence of breathing and retaining too much coal dist. When coal dust collects in the sunall passages leading to air spaces in the lungs, the lung tissues react with the dust to form masses of dense fibrous tissue. Black hung, a ptogressive disease, caubes diffculty in breathing and persistent coughing, and can put a fatal strain on the heart. Miners with the disease are eligible for disability under the Federal Black Lung Benefits Act of 1977 and its amendments, a program funded through taxes paid on coal production at a rate of $\$ 1.10$ per ton for underground mines and 55 cents per tom for surface mines. However, most of the Black Lung claims filed before 1973 are administered through the Social Securtity Administration.

\section{Coal Miners' Unlons and Strikes}

The United Mine Workers of America (UMWA) ranks first among about 40 labor unions that represent U.S. coal miners. Formed in 1890, the UMWA has been the leading coal miners union and has been in the forefront as a collective bargaining organization representing coal miners. It is the major unton in the coalfields in the East. UMWA coal miners currently accormt for about 40 percent of the U.S. coal miring workforce and produce about one-foutth of the total coal output. Other tmions 
represent 4 percent of the coal miners and account for a 9-percent share of production. By contrast, nonunion workers compose about 55 percent of the coal mining workforce and ancount for about two-thitds of U.S. coal production.

Major coal miners' strikes-those creating a significant disruption on coal supplies-are generally precipitated when a contract expires and no agreement is reached between the UMWA and the Bituminous Coal Operators Association (BCOA) over the terms of a new contract. The principal bargaining issues focus on wage and fringe beneftis, including health and retirement benefits. Contract agreements between the UMWA and the BCOA traditionally set the pattern for contracts between snaller unions representing coal miners and other mining companies or associations that do not belong to the BCOA, such as the Independent Bituminous Coal Bargaining Alliance. Overall production is usually not significantly affected by the small "wildcat" strikes that occur locally from time to time, usually over miners' grievances and local issues.

During a major strike, nonunion mines may also be idled by pickets or by miners walleng out in "sympathy" strikes. Generally, strikes by the UMWA are most significant at underground mines in AppaJachia, the center of UMWA membership. Before 1984, major coal miners' strikes were generally rationwide. Since then, the UMWA's tactic has been to call selective strikes against one or more companies. The striking miners are supported through UMWA payroll assessmants into a selective strike fund.

The early history of the coal industry often featured long strikes, commonly over needed reforms. In 1922 , anthracite miners in Pennsylvania went on strike for 160 days and bituminous coal miners for 140 days. The Nation's longest coal miners' strike-166 days in the anthracite region-was in the fall and winter of 1925-26, before the Taft-Hartley Act for ending strikes was enacted. In 1949-1950, a coal miners' strike lasted 116 days, although the miners went back to work several times during that period. Since 1960, major coal miners' strikes have occurred in 1966 (16 days), 1968 (13 days), 1971 (44 days), 1974 (28 days), 1977-78 (111 days), and 1981 (72 days). In October 1984, a nationwide strike was averted tor the first time in 20 years with the signing of a new UMWA-BCOA contract extending through January 1988, and in early February 1988 another new agreement was ratifted without striking. The new contract was for 5 years, whereas past contracts usually lasted about 3 years.
From April 1989 through mose of February 1990, a UMWA strike against the Pittston Coal Company, with which it was negotiating a separate contract, affected the company's mines in Virginia, West Virginia, and Kentucky before a 4 1/2-year agreement was reached. At issue were job security and health and retirement benefits. In 1993, unsuccessful contract negotiations between the UMWA and the BCOA led to a sertes of selective strikes that idled more than 16,000 miners in seven States in Appalachia. The tirst selective strikes were agatust the operations of Peabody Holding Company, the Nation's top producer, and Eastern Associated Coal Cotporation. The strikes lasted from Febratary 2 to Manch 3 and ended when the negotiators agreed to extend the contract for 60 deys. Failing to reach an agreement at the end of the period, the union expanded its selective strikes to include large mines operated by other companies. This new sertes of strikes lasted from May 10 until December 14, 1993, when an agreement was reached that will remain in effect through August 1, 1998. In addition to increasing wages and pensions, the new agreement provides for 60 percent of new job openings to be filled by UMWA workers, increases health care benefits, and gives the company the right to establish 7-day work schedules. In a separate collective bargaining agreemenk signed fune 20, 1994, the UMWA and the Pittston Coal Company concluded a new labor pact in June 1994 that extends through 1998.

\section{Preparation}

Most of the coal produced in the United States undergoes some degree of processing, or preparation, to make it a more marketable product. The amount of preparation required depends on the customer's specifications. Some coal is blended at the mine where, for example, high-sulfur coal from one area can be mixed with low-sulfur coal from another to produce a medium-sulfur coal that is acceptable to a consumer. Roughily half of the bituminous coal currently mined is sent to preparation (or processing) plants for some form of coal cleaning. About two-thirds of the bituminous coal mined in the East for electric power plants is cleaned, whereas the subbituminous coal and ligrite shipped from westem mines to electric utilities is generally only crushed and screened to facilitate handling and to remove extraneous material introduced during mining. Nearly all of the coal used to make coke fot steelmaking undergoes a high level of cleaning.

Cleaning upgrades the quatity and heating value of coal by removing or reducing the amount of pyritic sulfur, 


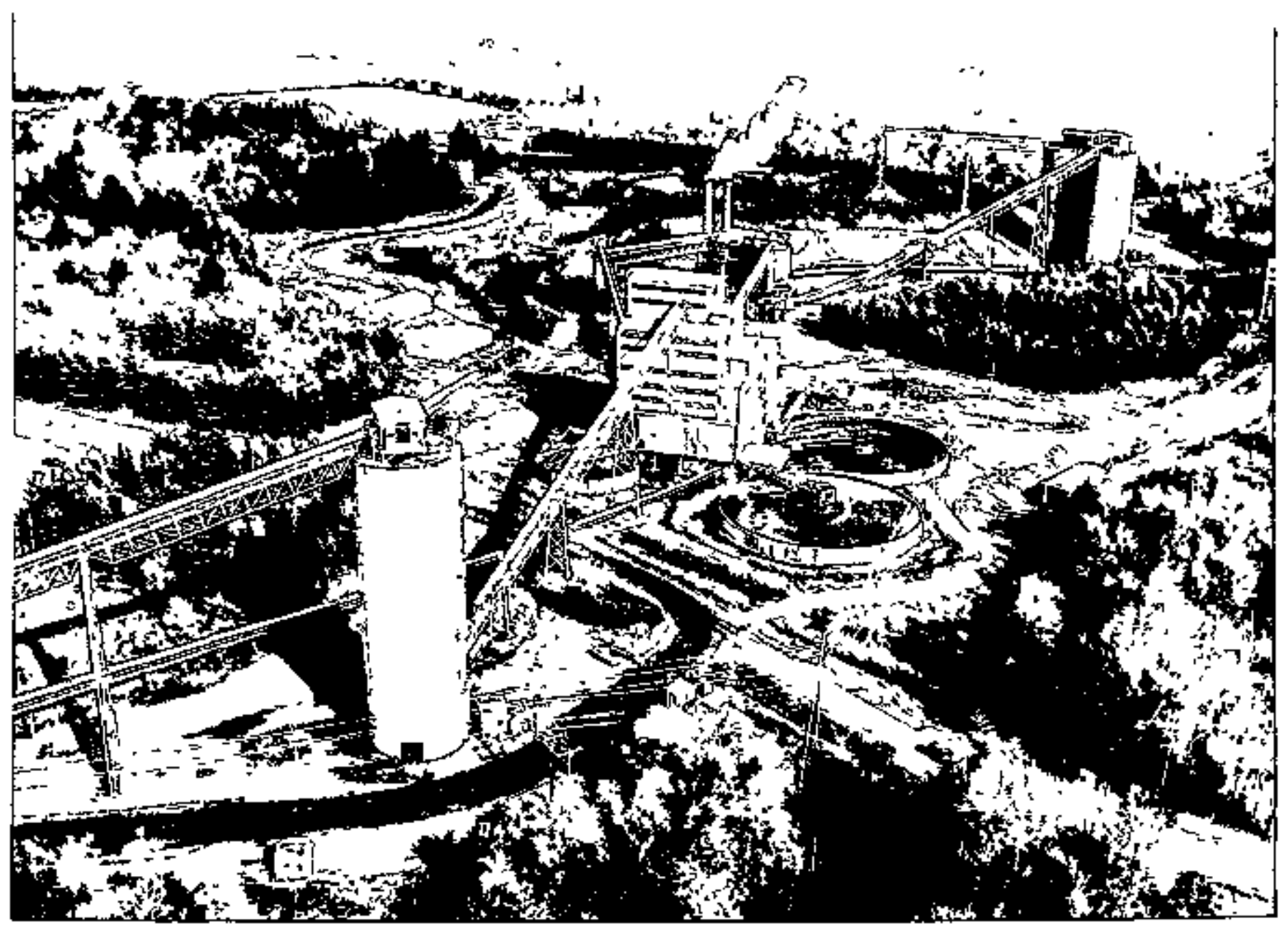

Cosl qually is upgraded in a preparation plant. This plant in wistem Maryland can profess 1,500 short tons of cali per hour.

rock, clay, and other ash-producing material. Cleaning also removes materials that becomes mixed with the coal during mining, such as wire and wood. Conventonal clearing methods generally remove up to one-thitd of the inorganic (pyritic) sulfur in coal, but none of the organic sulfur. Currently, commercial technology is not available for reducing the levels of the alkali metals sodium and pokassium. In general, about 30 tons of refuse are removed from every 100 tons of raw (as-mined) coal that is cleaned.

Coal cleaning is based on the principle that coal is lighter than the rock and other impurities mixed or enbedded in it. The impurities are separated by various mechanical devices using pulsating water currents and rapidly spinning water. The large buoyancy difference between coal's combustible matter and its mineral impurities is exploibed efficiently with the use of liquids of different densities in dense-medium systems, which are used in about two-thirds of the plants. The finely powdered cool (coal fines) produced during mining. handling, and crushing operations is usable but difficult to clean and handle. Finely sized coal is cleaned by froth flotation, a relatively high-cost chemical/physical process in which the coal adheres to air bubbles in a reagent ard floats to the top of the washing device while the refuse sinks to the bottom. About 40 percent of the US. cool cleaning capacity consists of plants that use froth flotation to recover coal fines. The remaining plants either discard the coal fines as refuse or mix uncleaned coal fines with the cleaned coal for shipment to customers. Oil aggloneration has been used to a limited extent to clean ultra fine coal. The oil clings to the coal surface, causing it to agglomerate while other refuse particles remain suspended and are removed. 
Coal cleaning consists of the following basic steps involving phystcal preparation and physical cleaning: (1) crushing gutinding and/or breaking, to prepare the coal for the washing ptocess; (2) sizing, to separate corl into different dimensions, both to match the specifications for the various cleaning devices and to meet market requirements; (3) washing, to remove ash and sulfur components from coal; (4) dewatering and drying, to remove excess moisture and prepare the cleaned corl for shipment and also to increase its heat value (Pigure 10). Cleaned coal of different sizes and properties can be blended at the plant to meet consumer requirements.

Figure 10. Basic Flow of Coal Through a Preparation Plant

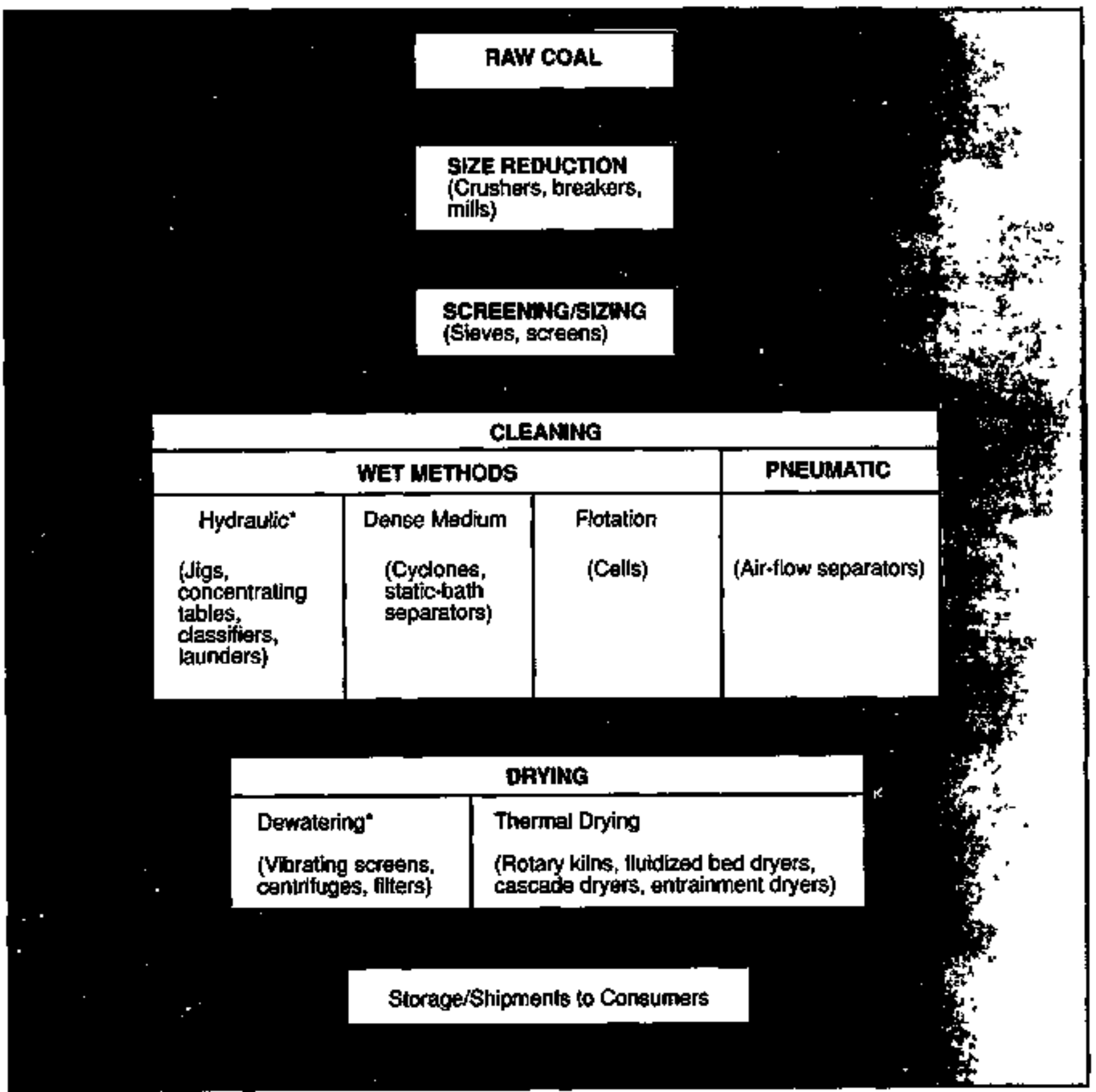

Coal preparation reduces the amount of impunties (sulfur and ast-pnoducing minerais) and improves the heating vaile; coals with oifferent characteristics can be blended to meet certain speciffoatbons. 
There were 270 coal preparation plants operating in the United States in 1993, according to Coal magazine. Varying widely in levels of complexty, the plants had capacities ranging from 40 tons to 3,200 tons per hour. Most of the plarts were in the East, with those in West Virginia and Pennsylvatite accounting for nearly half of the U.S. total. The largest preparation plant was the Bailey plant of Consol Pennsylvaria Coal Company in Graysville. Preparation plants in the bituminous coal region are sometimes called "tipples," because in the past coal cars were "tippled," of dumped, into the top of the plant; today, transfer is accomplished by conveyor. In the anthracite region, preparation plants are often called "breakers," a name originating in the fact that anthracite, a relatively hard coal, is broken and sized in the plant.

\section{Transportation}

The coal industry depends heavily on the transportation network for delivering coal to customers across the country. The flow of coal is carried by railroads, barges, ships, trucks, conveyors, and a slurry pipeline. Coas deliveries are usually handled by a combination of transportation modes before finally reaching the consumer. The methods of transportation and the shipping distance greatly influence the total cost of coal to the consumer. For some westem coals shipped over a great distance, the freight cost may represent three-fourths of the delivered cost of coal.

Railroads are the foundation of the coal distribution system, annually handling about 60 percent of the coal shipped to domestic customers. Just as railroads are important to the coal industry, coal shipments, in tum, are the leading source of freight and revenue for the railroad industry. In 1993, coal conslituted nearly 40 percent of railroad freight tonnage and provided over $\$ 6$ billion in revenue, generating about 21 cents out of every dollar of freight revenue earned, according to the Association of American Railroads.

Since 1970, railroads have accounted for a steadily larger share of coal shipments from the West (increasing from 61 percent to rearly 70 percent of the total in 1993), reflecting a greater dentand for lowsulfur westem coal as well as improvements in the area's rail transportation system, particularly in Wyoming. Over the same period, ralloads handled an average of $\$ 5$ percent of Appalactia's coal shipments. Rail's share of coal shipments in the interior region dropped from 51 percent to 45 percent, due mainly to a fall in the demand for the region's high-sulfur coal to produce electricity and for its coking coal Currently, the three leading States in which domestic coal shipments originate by rail are Wyoming (35 percent of U.S. rail shipments in 1993), Kentucky (18 percent), and West Virginia (10 percent). The largest coal-carrying railroads are CSX Transportation Incorporated, Burlington Northem Railroad Company, and Norfolk Southem Corporation, which sogether handle over three-fourths of all U.S. coal shipped by rail.

Unit trains account sot more than half of railroad coal shipments. Unlike a conventional coal train or a mixed freight train carrying individual carloads of coal, a unit coal train carries coal from a spectified loading facility straight through to a specified customer without stopping. It uses dedicated equipment, whereas other trains carrying coal generally draw the equipment needed from the tailroad's operating pool of locornotives and cars Sontetimes termed "the train with a one-track mind," a unit coal train operates on a predetermmed schedule, following the most direct route and providing high productivity and low shipping rates. Comprising as many as four or five locomotives and 100 to 110 cars, a unit coal train is over a mile long. It can be loaded with 10,000 to 11,000 tors of coal in 2.5 to 3 hours and unloaded in 4 to 5 hours. In some States, turit coal train traftic can be heavy. In Wyoming, the leading coalproducing State, about 40 unit coal trains left the State daily in 1990 white a like number returned for relowading, according to the Wyoning State Geplogical Survey.

Two types of railroad cars are used for transporting coal, the gondola and the hoppes. Gondola cars have flat bottoms, straight sides, and open tops and are unloaded by being tipped over by rotary dumpers. Hopper cars have sloping bottoms with gates that open to discharge the coal. Today's rail cars hold an average of about 96 tons, nearly 20 percent more than in the easly 1970's and almost double the capacity of railroad cars in the $1930^{\prime}$ s. Cars used for eastern coal are slightly smaller than those for westem coal, the difference reflecting the density of the coal carried. Eastern coal is denser than westem coal and so the equipment designed to haul it has a smaller capacity. Most cars ate made of steel, but a large number of aluminum-bodied cars are also used. Lighter in weight, aluminum cars offer a savings in transportation cosis because they can carry 5 to 10 tons more than steel cars without exceeding track weight imitations. On the retum trip, the lighter cars also result in fuels savings.

Waterbome shipments rank next to railroads in coal shiprients, accounting for nearly 2 out of every 10 tons of coal shipped arunally to domestic markets. However, the proportion of total domestic coral 


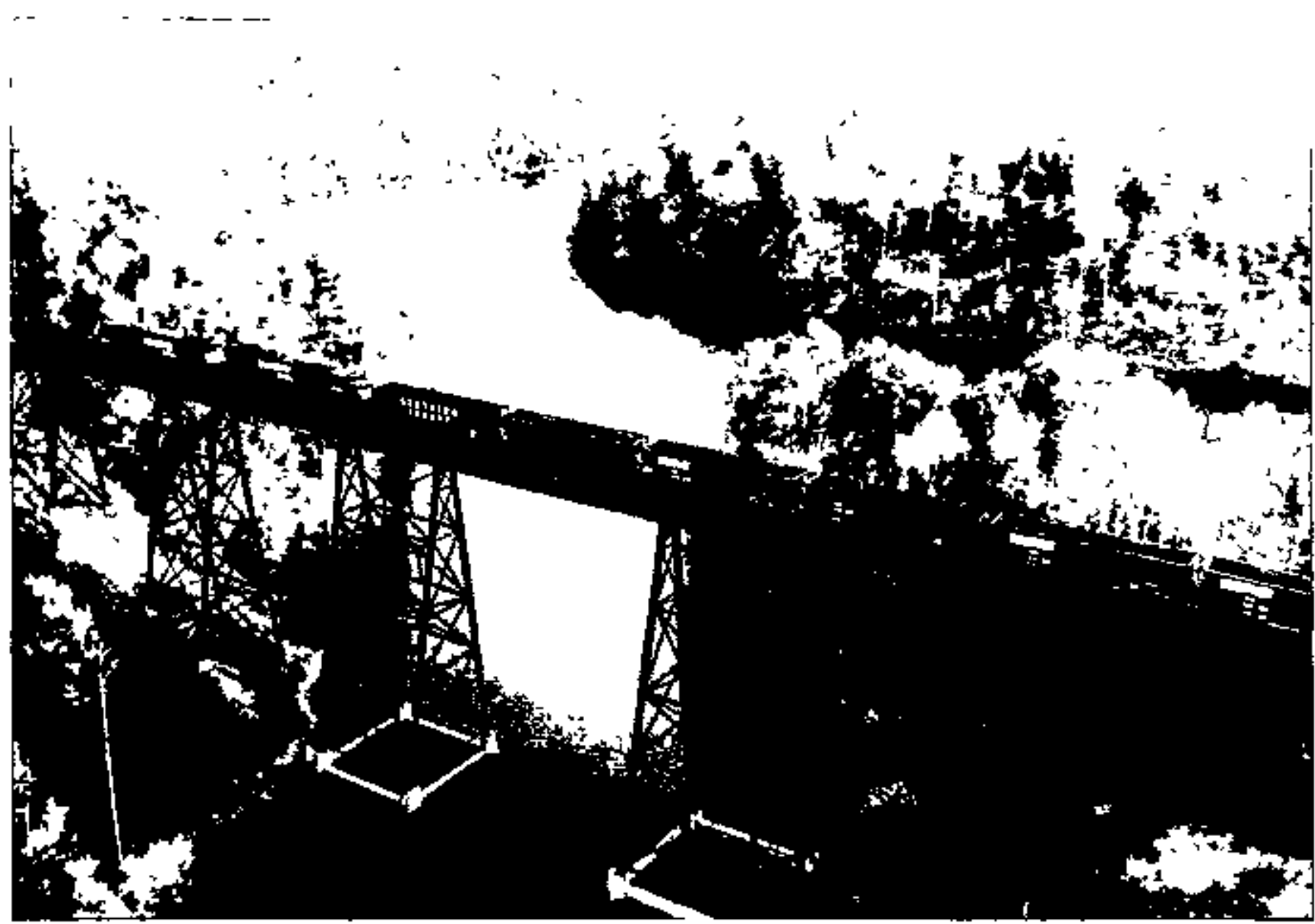

The unit cosl train is the symbol of cosl transportation. Ralkoads are the foundation of the cosi distribution system. Canversely, cool is the leacing source of radroad freight and reventie.

shipments moved by water has declined from 29 percent in 1970 to about 17 percent in recent years, reflecting in part the shift of coal production away from the Northeast and Midwest, the regions with the greatest use of water transportation. Kentucky and West Virginia are the leaders in water transport of coal, together accounting for a little more than half of the total in recent years. Coal's approximate share of total domestic shipments of major commodities by type of waterway in 1991, according to the U.S. Arrny Corps of Engineers, was as follows: coastal, 5 percent; Great Lakes, 17 percent; and inland waterways, 30 percent.

Barges and ships move coal on rivers, the Great Lakes, and tidewater areas. The major inland waterways for coal traffic are the Mississippi, Ohio, and Black Wartor-Tombigtee rivers. Towboats piying these waters typically push 15 to 20 barges loaded with 20,000 to 30,000 tons of coal. The amount of coal shipped in a single tow (a string of barges) is determined by the lock size on the waters navigated. Large tows can be handled in the deeper waters of the lower Mississtppi River. On the Great Lakes, domestic coal traffic generally ranks second to iron ore. Shipments are typically made by lake carriers, which are about 700 feet long and 70 feet wide and hald about 20,000 tons of coal. Several lake carriers ate about 1,000 feet long and have about three times more capacty. The most extensive coal traffic on the lakes is to destinations in the north and west. Lake carrfers saiting south generally contain zron ore or grain. Shipping on the Great Lakes usually is immobilized by ine from mid-Decenber through mid-March. Some coal deliveries from eastem ports to power plants in Massachusetts are carried by a coslbuming collier, Energy Indepenterce, placed in service in 1983.

Coal deliveries by truck account for about 1 out of every 10 tons of coal shipped. The level of coal transportation by truck has not varied significantly in the past two decades. Although the use of trucks for hauling coal is widespread, it is very important in a 
number of States, toncluding Alabama, Indiana, Pernsylvanta, Texas, and Utah. Trucks are used for short hauls, generally of less than 50 miles. Frequently, coal transported by rail or barge is first trucked to the loading dock or transferred by truck at some point. In some areas, such as parts of the Appalachian Region, trucks are the only economical way to transport coal. Individual coal shipments by truck are relatively small. Three-axle dump trucks hold about 20 tons; tractortrailers carry up to $\mathbf{3 5}$ tons. The maximum load a truck can carry on highways is limited by State regulations.

Aerial tramways, conveyors, and a coal slurry pipeline together account for about the same amtount of coal deliveries as trucks. The percentage of coal shipped by this transportation category has increased from about 4 percent in 1970 to about 13 percent in recent years. This growth was partly due to the rapid growth of coal production in the West, where conveyors are often used to deliver coal directly from mines to nearby power plants.

Aerial tramways cover relatively short distances, but conveyors usially are many mik long, commonly linking mines with power plants. The Nation's only coal slury pipeline is the Black Mesa line Spaning 273 miles, this pipeline is 18 inches in diameter and conuects a coal mine in northen Arizona to a power plant in southem Nevada. It carries about 4.5 mallion tons of coal annually in a slurry compased equally of finely ground coal and water, the journey from mine to plant taking about 3 days. About 1 billion gallons of grourdwater are used annually. There are 9.7 million gallons of water and 45,000 tons of coal in the pipeline at any one time. The Black Mesa coal slurry pipeline began operations in 1970, about 7 years after the closing of the Nation's tirst long-distance coal slurry pipeline, the Eastlake, which carried coal from Cadiz, Ohio, to a power plant east of Cleveland.

\section{Supply and Stocks}

In recent years the supply of coal from U.S. mines has averaged about 19 million fors per week. This is more than enough to provide the fuel required to generate electricity for a metropolitan area the size of New York City for about a year. The weekly supply of coal from the mines varies considerably. Sharp rises occur in response to increased demand, including increased use of colat-fired electricity generation to offset declines in generation from other sources. These declines occur, for example, when nuclear power generation drops because of scheduled maintenance, when hydroelectric generation falls during periods of low water, or when coal stockpiles are built up in anticipation of a coal miners' strike.

Downward swings in weekly coal production and supply usually are caused by miners' vacations and holidays. Strikes by coal miners and workers involved with coal shipments car sharply curtail the supply of coal from the mines. Delays in delivering railroad cars to the mines can result in a drop in coal shipments. Freezing temperatures can hamper the unloading of railroad cars. Although coal shipped by rail in winter is generally treated with treeze-control agents, this protective treatment can be washed away and the coal can freeze solid in the railroad cars. Coal frozen in railroad cars is thawed in heated sheds and/or mechanically broken into pieces of manageable size. Heavy rains and flooding can also impede mining operations and coal shipments. For instance, from June through August 1993, severe flooding along the upper Mississippi and Missouri river basins distupted coal deliveries to power plants in about rine Mídwest States and to power plants an States beyond that area, because trains were delayed or rerouted around the flooded region.

As insurance against a disruption in detiveries, large coal consumers generally maintain a 45- to 60 -day stockpile of coal. Large quantities of coal are generally stored in open stockpiles on the ground, piled in diverse forms, such as cones, blocks, and rows. Coal is also stored in covered ground storage-in bins, burkers, and silos.

Year-end coal stocks since 1990 have averaged nearly 190 million tons, equivalent to about one-fifth of the average annual coal consumption. More than 80 percent of the stockpiled coal was at electric power plants.

\section{Use}

Coal is used in all 50 States and the District of Columbia. In 1993, 10 States accounted for about half of the total coal consumed (Table 7). Of these, Texas, Indiania, Ohio, and Pensylvania constumed the lergest amourts, with a combined share of 29 percent of the tonnage. However, based on the estimated energy content of the coal constumed, the ranking was as follows: Ohio, Pennsylvania, Texas, and indiana.

The tuse of coal in the United States has risen almost steadily since the early 1970 's, reaching record levels and totaling 926 million tons in 1993. On a per capita basis, coal consumption in 1993 was nearly 20 pounds per person per day, which continued an upward trend 
Table 7. The 10 Leading U.S. Coal-Consuming States, 1993

(Million Shart Tons)

\begin{tabular}{|c|c|c|}
\hline State & Consumpilon & $\begin{array}{c}\text { Parount of } \\
\text { Total }\end{array}$ \\
\hline Texas $\ldots \ldots \ldots \ldots \ldots \ldots \ldots$ & 96.8 & 10.5 \\
\hline Indieng . . . . . . . . . . . . . . & 60.4 & 6.5 \\
\hline Ohio $\ldots \ldots \ldots \ldots \ldots \ldots+\ldots$. & 59.0 & 6.3 \\
\hline Penneytrania $\ldots \ldots \ldots \ldots \ldots$. & 502 & 6.1 \\
\hline Kenkucky . . . . . . . . . . . . & a9.1 & 4.2 \\
\hline IOnds $\ldots \ldots \ldots \ldots \ldots \ldots \ldots$ & gB.1 & 4.1 \\
\hline Alubsang,$\ldots \ldots+\ldots+\ldots \ldots$. & 39,0 & 3.6 \\
\hline Mllchigen $\ldots \ldots \ldots \ldots \ldots \ldots$ & 32.2 & $\mathbf{3 . 5}$ \\
\hline West Virginig $\ldots \ldots \ldots \ldots \ldots$ & 32.0 & 3.5 \\
\hline North Dakota $\ldots \ldots \ldots \ldots \ldots$ & 30.3 & $\mathbf{3 . 3}$ \\
\hline Total $\ldots \ldots \ldots \ldots \ldots \ldots \ldots \ldots$ & 477.2 & 51,4 \\
\hline U.S. Tolel . & 025.9 & 100.0 \\
\hline
\end{tabular}

Note: Totel does not equal sum of components because of indepandent rounding.

Source: Energy milomation Administration, Qubrterty Coal Report

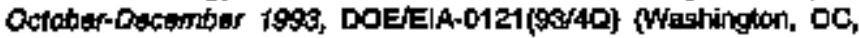
Mey 1984); and Ouartenty Coal Raport damuany-hareh 1994, DOE/EiA-0121(84/1C) (Wastington, DC, Augusi 1994).

that began in the 1960's (Figure 11). Virtually all of the growth has been due to the increasing amounts of coal used to generate electricity.

The upward trend in cọal consumption was spurred by the Arab oil embargo in the first half of the 1970 's, which caused substantial price increases for petroletun, and by a natural gas shortage in the second half of the 1970 's. As a result, the share of total U.S. energy consumption supplied by coal has increased significantly. At the time of the Arab oil embargo, coal accounted for 17 percent of U.S. energy constumption. In 1993 its share was 23 percent. Historically, however, this is a markedly smaller proportion than in the early 1900 's, when coal supplied nearly all of the U.S. energy needs, or 1940, when it supplied about half.

In recent years, the increase in energy supplied by coal has not matched the increase in coal tonnage. For example, the amount of coal consumed increased by 32 percent from 1980 through 1993, but the energy derived from the coal in 1993 was only 26 percent higher than in 1980. The difference is due to the greater use of subbituminous coal and lignite, which are mined in the West. Both have a relatively low heat content as compared with bituminous coal, which held a larger shate of consumption in earlier years.
Figure 11. U.S. Daily Per Capila Coal Consumption, 1950-1999

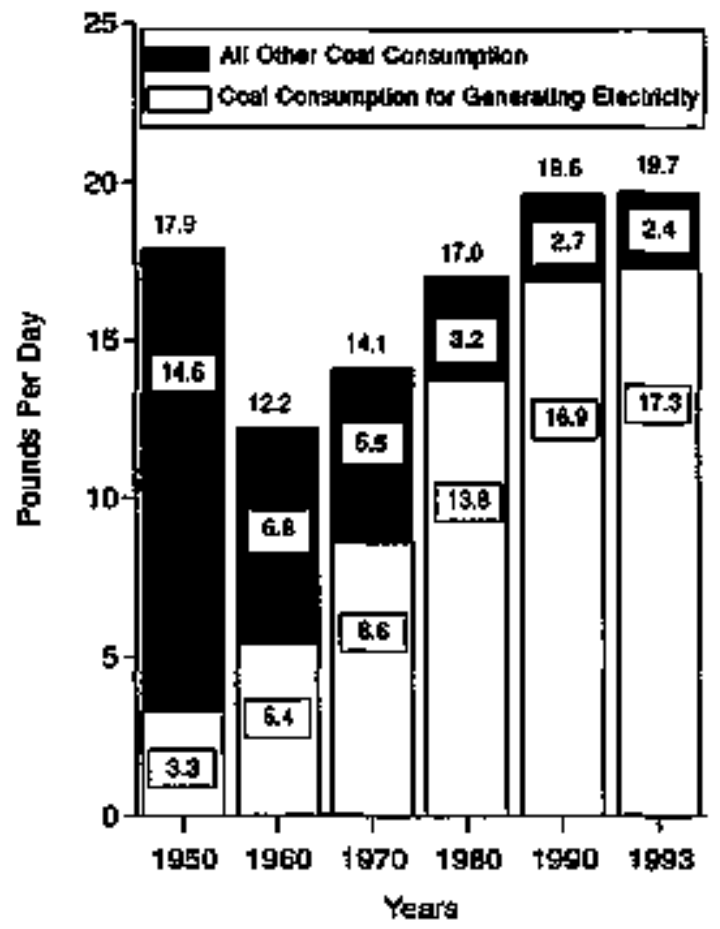

U.S. daily per ceppita cod consumplion has risen since the 1960 s ofle chithy to an increase in the amount of coal used for generating electricky.

Source: Bureau of Manes, U.S. Department of Interior. "Mineral Yearbaok," various issues; Energy Information Administration, "Quarterly Coal Report," DOEELIA-0121, various issues; and Bureau of the Census, U.S. Department of Commerce, "Statistioal Abstracts of the Uniaded States," various issues.

More than 8 out of every 10 tons of the coal used in the United States are for electricity generation, the most important market for coal since the 1950's. The coal is used to produce high-pressure steam for driving an electrical generator (Figure 12). Due to the cost advartage that coal offers over oil and gas, the amount of coal used by utilities amnually has trended upwards. Although electricity generated from nuclear power increased in the 1970's and 1980's, at the expense of petroleum and gas, coal's contribution was on an upward trend, generally keeping pace with the growing demand for electricity. Part of the reason for the rise was the Powerplant and Industrial Fuel Act of 1978. The law prohibiled the use of oil or gas in most new large boilers and compelled utilities to convert many 
Figure 12. Schematic of a Coalfired Power Plant

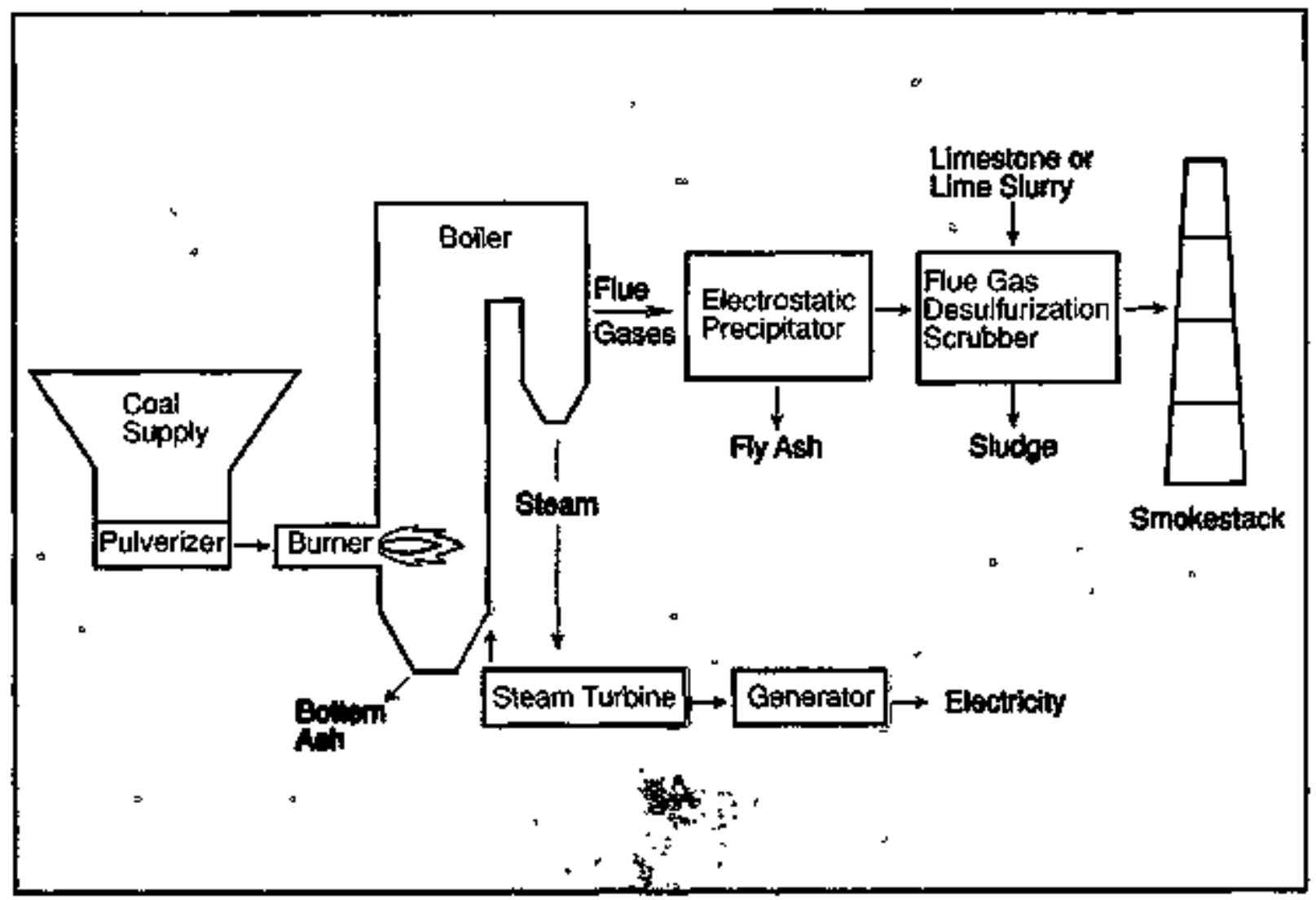

Most coal-fined power plants bum pulverized coal to produce high-pressure stean. The steam, in tum, nus a turbine that drives an elecbic generetor. Most of the coel ass is cemied in fitse gas as fly ash and removed chiefly by elactrostatic prectipitators, but

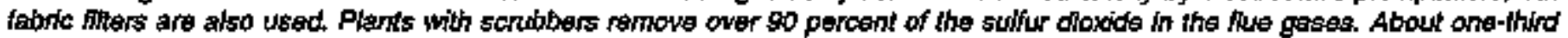
of the enargy released during casl combustion is carvierted into electricity.

existing oil- and gas-fired boilers to coal. The law was amended in 1978 to repeal restrictions on the use of oil or gas in new baseload power plants if they were designed to perrnit future conversion to coal, but the later regulations became redundant because rapidly rtsing petroleum prices and natural gas shortages in the $19 \%$ 's gave coal the economic advantage.

Utility coal consumption has risen from less than 400 million tons per year during the early 1970 s to more than 800 million tons in 1993 . The electricity generated from coal has increased from 704 billion kilowatthours in 1970 , when it accounted for $\mathbf{4 6}$ percent of the total, to a record 1,580 billion kilowatthours in 1993, when its share was 57 percent By comparison, of the total electricity generated in 1993, nuclear power supplied 21 percent; natural gas and hydropower, 9 percent each; petroleum, 3 percent; and geothermal and other sources, 1 percent.
In addition to the electricity produced by utility companies, a strall amount of electricity is generated by nonutility power producers, chiefly industrial plants that produce it for their own use. In 1993, coal-fired generation in this sector totaled about 43 billion kilowatthours.

Most of the coal used to generate electricity is burned in pulverized-coal-fired boilers. Pulverized-coal firing, introduced in the electric utility industry in the early 1920 's, is a major improvement over other methods of coal combustion because it permits the use of larger, more efficient boilers. Pulverized coal, which is ground as tine as flour, is blown into the fumace and ignited instantly to burn in suspension. The most conmon pulvertzed-coal boilers are classified as having a "dry bottom" because the coal ash does not reach fusion temperature. About 80 percent of the coal ash produced is carried in the flue gases as fly ash, while only 20 
percent of the ash settles to the bottom of the furnace This type of unit operates most efficiently with coals that have an ash fusion temperature that is above the fumace temperahure, so that slag (moiten ash) does not form. A "wet bottom furnace" is designed so that ash fuses to form slag. The coal ash produced consists of approximately half fly asth and half bottom ash, which is drawn off as slag.

A smaller amount of utility coal is used in stoker furnaces, which are supplied with crushed coal on a moving grate; and in cyclone furnaces, which bum crushed coal carried in a whirling stream of air. A few generating plants use fluidized-bed combustion, a technique for burning crushed coal (often of low quality) in a bed that behaves like a boiling fluid as currents of high-velocity air flows through it

Currently, U.S. coal-fired power plants produce about 90 miltion tons of combustion byproducts in the form of fly ash, bottom ash, boiler slag, and flue-gas desulfurization material. About one-fourth of these byproducts are used in various ways, such as in cement and concrete production and as roadbase materials; the rest is disposed of in surface impoundments, landfills, and waste piles.

Nearly 500 of the 3,000 powet plants in the United States use coal. In 1993, these coal-burning plants were located in 44 States. Eight of the States relied on coal for over three-fourths of their senerating capabjlity. Another 14 States depended on coal for 50 to 75 percent of their electricity generation. The five leading States generating electridity from coal were Ohio, Texas, Pennsylvania, Indtana, and Kentucky. The largest U.S. coal-fired power plants are the Scherer plant ( 3.3 million kilowatts of summer generating capability) and the Bowen plant (3.2 million kllowatts) of Georgia Power Company; the Gibson plant (3.1 million kilowatts) of PSI Energy, Inc, in Indiana; and the Monroe plant (3.0 million kilowatts) of Detroit Edison Company, in Mlchigan. Each of these power plants can generate enough electricity for a city with a population of over 1 million. Large power plants consume coal at rates of more than 20,000 tons per day, the amount of coal held by about 200 ratlroad cars. Some power plants are minemouth plants, constructed near one or more mines that provide a convenient source of coal. In general, each ton of con consumed at a power plant generates about 2,000 kilowatt hours of electricity. A pound of coal supplies enough electricity to light ten 100-watt bulbs for about an hour.
Another use of coal is to make coke for the iron and steel industry, foundries, and other industries. The presence of large domestic deposits of coking coal, or metallurgical coal, played an important role in the development of the U.S. iron and steel industry. Coke is used chiefly to smelt iron ore and other iron-bearing materials in blast furnaces, acting both as a source of heat and as a chemical reducing agent, to produce pig iron, or hot metal (Figure 13). About 1,100 pounds of coke are consumed for every ton of pig iron produced. Foundries use coke as a source of heat for producing metal castings. Other industrial ues of coke include the smelting of phosphate rock to produce elemental phosphorous and the production of calcium carbide. Srrall sizes of coke, termed breeze, are used as fuel in sintering finely sized particles of iron ore and other iron-bearing material to produce an agglomerate that can be used in a blast furnace.

\section{Figure 13. Using Coke in a Blast Furnace to Make Iron}

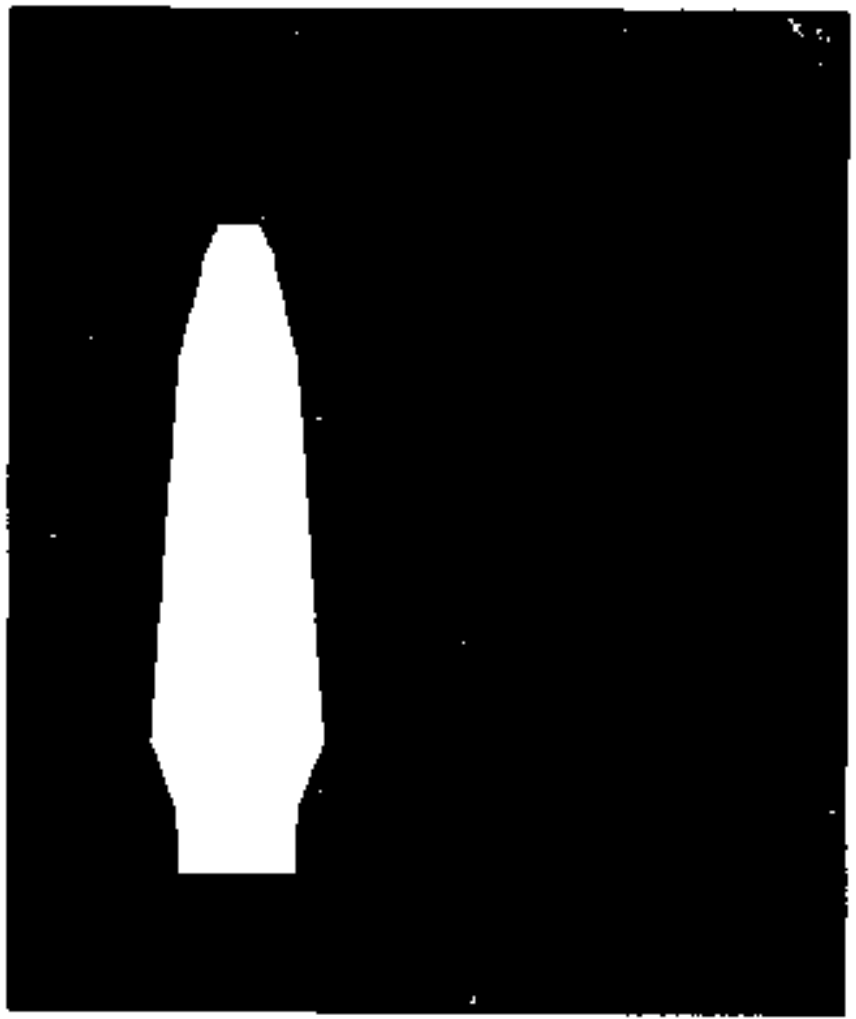

Coke, Iron ore, and limestone are fed into the blast fumace, which rums continuously. Hot air blown into the fumace bums the coke, which senves as a source of hoat and an oxygen. rectucing egent to producte metadic iron. Limestone acts as a flux and also combines with impunities to form slag.

Source: Ammrican Iron and Steel Institute. 
Coke is made by baktng a blend of selected bituminous coals (called metallurgtcal coal or coking coal) in special high-temperature ovens without contact with air until almost all of the volatile matter is driven off. The resulting product, coke, consists principally of carbon. A ton of coal ytelds about 1,400 pounds of coke and a variety of by-products such as crude coal tar, light oils, and ammonia, which are refined to obtain various chencical products (Pigure 14).

The coke industry was once a major market for coal, accounting for about one-fourth of U.S. coal consumption as recently as the late 1950's. Since then, coke production has fallen dramatically and its share of total coal consumption cutrently is about 4 percent because of a decline in the US. iron and steel industry, the principal consumer of coke. In general, the iron and steel industry now tequires less coke because it produces smalter amounts of raw steel, relying on imports of fusushed and semi-fintshed steel to help meet its needs, and because improved blast-fumace technology has reduced the amount of coke needed to produce a ton of pig inon. Furthermore, less coke is needed dure to the greater use of certain steel-making technologies, such as the basic oxygen fumace, which enables scrap iron to replace pig iron in some processes, and the electric arc furnace, which produces steel from a charge consisting of 99 percent scrap lron and recycled steel and 1 percent iron pellets. (The steel industry has not used the open-hearth furnace since 1991.) The substitution of other products for steel (such as plastics, aluminum, magnesium, and titanium) has also indirectly reduced the need for coke.

Arrong the recent technological thanges that are responsible for reducing the use of traditional coke in blast furnaces is the use of pulverized coal injection, a process developed in the 1960's by Armco Steel. By using pulverized coal injection, steel companies can reduce the need for coke by as much as 40 percent, cut down on environmental problems associated with coke production, and reduce the need for other, more costly supplemental blast fumace fuets, such as natural gas. Pulverized coal, which has the consistency of face powder, is made from the relatively abundant lower grades of coal and blown into the blast furnace. Granular coal, simitar in size to sugar, is also being tested in blast furnaces.

At the beginning of 1994, 31 coke plants were in operation, less than half the number a decade earlier. Although some plants were closed because of the decline in the steel industry, many closings targeted older plants that were shut down because of the high cost of refurbishing therr to meet air pollution

Figure 14. Production of Coke and Coal Chemleals (Approximate Yields per Ton of Coal)

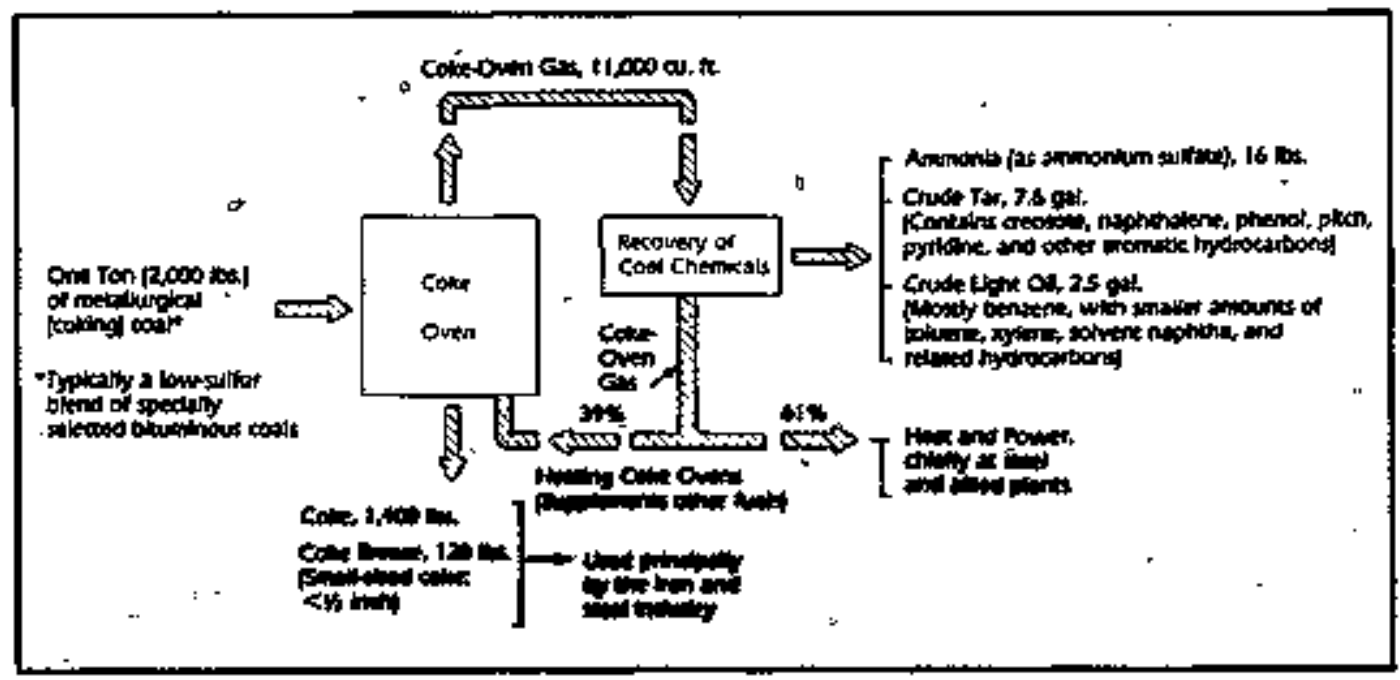

Metallugical (coloing) cosl is corrverted in spects high-temperature ovens into coke, which is used th smelting fron ore in a blast fumace. The coking process a'so yields useful coal chemicals as by-products. 
standards. More than half of the active plants are funtuce plants, operated by iron and steel companies to produce coke for their blast furnaces; these plants account for about $\mathrm{BO}$ percent of the U.S. coke capacity. The ather coke plants, called merchant piants, sell coke on the open market. Both segments of the coke industry are faced with the advanced age of many of their coke overs and the nising costs of replacing them with environmentally clean ovens. Indianta and Pennsylvapia are the leading coke-producing States.

Coal is also used as a source of heat in other industrial, manufacturing, and commercial establishments, as well as in homes. Most U.S. cement plants bum coal, using about a ton for each 3.5 tons of cement produced. A number of cogeneration plants consume coal to produce steam for generating electricity and for heating.

Since Decenber 1984, lignite has been converted into pipeline-quality gas at the Great Plains Syntuels Plant, near Beulah, North Dakota (Figure 15). The first of its type to operate commercially in the United States, the plant converts an average of 16,000 tons of lignite per day into 142 million cublc feet of gas. In 1987, a coal gasification facility began operations at Plaquemine, Louislana, to produce gas for the cogeneration of steam and electricity for the Dow Chemical Company. The plant has a coal processing capacity of 2,400 tons per day.

Sorne coal is used for transportation, but the amount is insignificant. The corl-burning locomotives of the past, now replaced by more efficient diesel-electric locomotives, were once major coal consumers requiring a coal supply that often exceeded 100 million tons per year. Today's corl-burring locomotives are used for tourist attractions and excursions, although one was in regular, short-haul revenue service in Illinois as recently as 1986. (It is interesting to note that research is underway to develop a new generation of coal-fired locomotives fueled with coal-oil mixtures, colal-derived liquiós, or coal gas.) A coat-fired ship more than 60 years old was reported in service on the Great Lakes in 1991. A large coal-fired ship, the Energy Independence, placed in service in 1983, transports coal from eastern ports to power plants in Massachusetts. The ship, 665 feet long and with a coal-capacity of about 36,000 tons, is the first of its type built in the United States since I929.

Although primarily a fuel, coal has other uses. The process of converting coal into coke yields by-products of benzene, coal tars, naphtha, and similar chemicals that are used to manufacture solvents, vamishes,
Figure 15. Schematle of Coal Gasitication, Great Plalns Synfuels Plant, Betlah, North Dakota

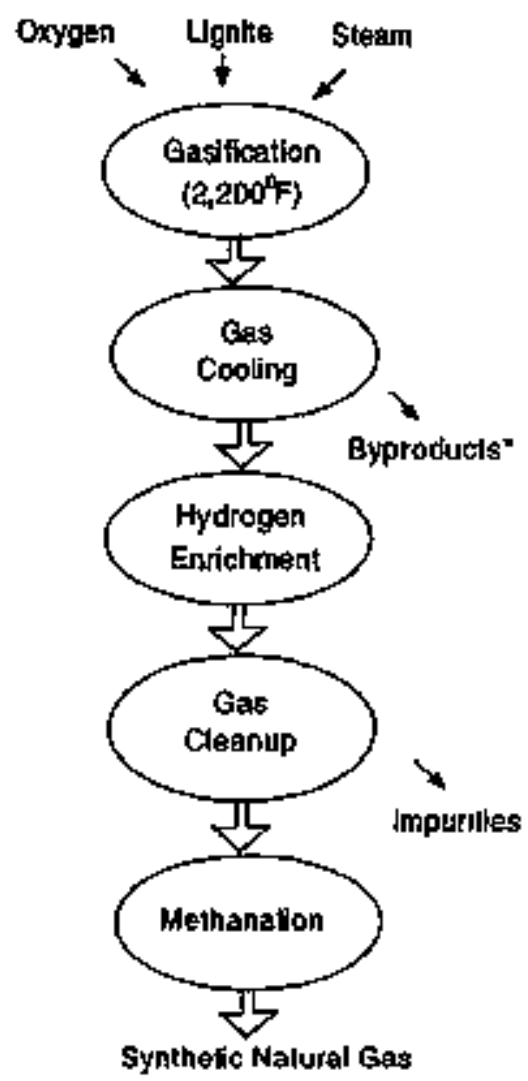

Includes ammonia, skilur, kquid ritrogen, kyplon, xenon, and phenols.

in coal gesificetion, the molecular structure of coal is broken down to produce hydrogen and carton, which are combined to fom (CH, the main constiluent of natural gess. Symthetic natural gas forms when catbon monoxtida and camon dioxde react with tydrogen in the presence of a nickel catajyst.

Sostce: Dakota Gasification Company.

perfunes, medicines, dyes, and plastics. In the past, coke plants were a major source of chemicals, but today their output is overshadowed by chemicals produced from petroleum. Coal is also used to manufacture diverse products such as calcium carbide, silicon carbide, refractory bricks, carbon and graphite electrodes, adsorbents, carbon black, and fillers. Since 1983, coal has been used as a raw material at Eastman Kodak's plant in Kingsport, Tennessee, to manufacture acetic anhydride, which is used in making photographic film base, acetate yams, and other plastic-based materials. Montan wax is extracted from certain lignites at Ione, in northem Califorria, for use in polishes, 
waxes, carbon paper, phonograph records, inks, coatings, and electrical insulating materials. Resin recovered from coal in Utah is used in making adhesives, rubber, vanish, enamel, paint, coating, thermoplastics, and ink. Oxidized lignite, or leonardite, from North Dakota has been used in oil-drilling nud, in water treatment, in certain wood stains, and as soil conditioners. Activated carbon is manufactured from lignite in Marshall, Texas. Some of the ash from coal-fired power plants is used in manufacturing concrete and cinder blocks, in constructing roads, and in reclaiming surface-mined areas.

\section{Coal and Coke Trade}

Coal exports comprise a small but important market for U.S. coal production. The kevel of coal exports, consisting of nearly all Appalachian bituminous corl, is influenced by a number of factors, wuch as changes in the economic conditions in the conl-importing countries, coal-miners' strikes in the United States and other coalexporting countries, and price competition, as weil as changes in the international exchange rate of the U.S. dollar, which determines the price foreign consumers pay for $\downarrow$.s. coal.

US. coal is currently exported to more than 30 countries (Figure 16). The United States was the world's leading coal exporter until 1984, when Australia gained first place. Annual U.S. coaI exports, valued at $\$ 3$ billion to $\$ 6$ billion from 1980 through 1993 , are a significant contribution to the Nation's balance of rade.

Since 1960, an average of 1 out of every 10 tons of coel mined has been exported. The arrount has ranged widely, from 36 million tons in 1961 to a record 113 million tons in 1981 and totaled 75 million tons in 1993. The 1993 coal exports were the lowest since 1979, a decline generally attributed to a combination of adverse factors: a slump in the world economy, a strike by the United Mine Workers of America, a slowdown of barge shipments due to flooding in the Mtdwest, and price competition from foreign coal producers. Although coal was exported in 1993 from 15 States, West Virgintat, Virginia, and Kentucky predominated, together accounting for three-fourths of the total.

Metallurgical coal, or coking coal, is the mainstay of U.S. coal exports, accounting for 67 percent of the 1993 total. However, exports of bituminous steam coal have expanded because many foreign electric power plants, certent planks, and other industries converfed from oil to coal when oil prices rose in the $197 \gamma_{\mathrm{s}}$.
Canada, historically, has been the principal export market for U.S. coal, including some anthracite for use in a smelting process to produce paint pigments. Western Europe becarne a major market for U.S. coal following World War II, especially for metallurgical coal, with the largest tonnages currently shipped to Italy, Belgium and Luxembourg, and the Netherlands. Japan has been predominant as a market for metallurgical coal since 1967. Brazil is the largest South American importer of U.S. netallurgical coal.

About haif of the total U.S. coal exported is shipped from the Norfolk, Virginia, customs district. Other large coal-exporting customs districts are New Orleans, Lousiara; Cleveland, Ohio; Baltimore, Maryland; and Mobile, Alabama.

Channel depths at most U.S. coal-joading terminals limit the vessel size to less than 100,000 deadweight tons. When a large collier (more than 100,000 deadweight tons) cannot be fully loaded because of chanueldepth restrictions, it is sometimes loaded by a two stage "top-off" operation. With this technique, the ship is partially loaded at the port and then sails to deeper waters where it is topped-off to full capacity with coal from a self-unloading barte. However, vessels using the Panama Canal are limited in size to 65,000 deadweight tons and are often described as "Panamax" ships. "Capesize" shúps are oceangoing vessels too large for the Panama Canal that must travel routes around the capes of Africa or South America.

Coal imports, contrasted with coal expotts, are rela. tively insignificant. In 1993, the 7 million tons of bituminous coal imported were valued at about $\$ 219$ million. The coal was imported chiefly from Colombia, Venezuela, and Canada Coal imported from Canada was used primarily to meet the needs of U.S areas not easily supplied by domestic sources. The coal imported from the other countries was delivered to electric power plants in the Southeast at prices below those of competing U.S. coal. Imported coal typically has a low sulfur content and is sometmes blended with highsulfur domestic coal to enable the latter to meet aitquality emdssion standards.

U.S. coke exports have been small and chiefly to Canada. Coke exports totaled 0.8 million tons in 1993. Coke imports over the past two decades typically have been less than 1 million tons, although larger amounts have been imported when needed to offset a shortfall in the domestic supply. Coke imports in 1993 amounbed to 1.5 million tons, mostly from Japan. Some coke was int ported from Canada for use by nonferrous industries in the West. 
Figure 16. Major Destinations of U.S. Coal Exports and Shipmente from Selected U.S. CoalExporting Customs Dlstricts, 1998

(Wilition Short Tons)

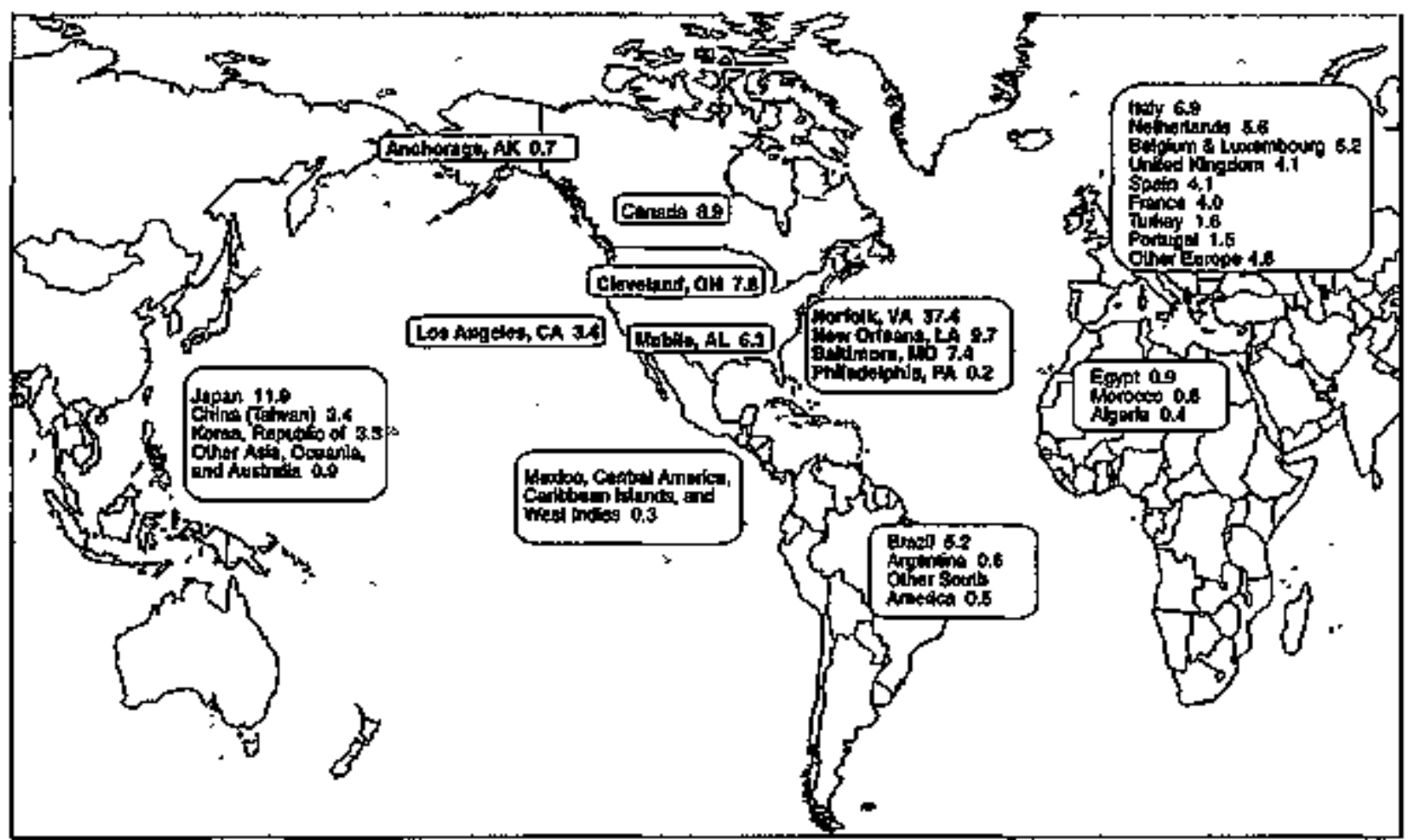

In 1993, a lotal of 75 miltion short lons of U.S. chal was exported to mare than $\$ 0$ countries. More than haff of the coal was shipped from Norfolk, Viginia.

Source: Energy frifomation Adminisaration, Quanterty Coal Report Octoher-December 1993, DOEJEA-0121(93/40) (Washington, DC, May 1994).

\section{Coal and the Environment}

Coal has played an important role in the advancement of civilization, but ths use has sometimes been accompanied by environmental penalties, due party to the mining process and partly to the composition of coal itself. Because of this, a number of laws have been enacted to protect the environment

Coal mining, like all other mining, has a direct impact on the environment. Most visible are surface-mined areas, although proper reclamation can restore the land for other uses after mining. The Surface Mining Control and Reclamation Act of 1977, which was extended and amended by the Abandoned Mine Reclamation Act of 1990, requires surface mine operators to matintain certain environmental standards during mining and reclamation. The Act also requires operators of underground mines to take measures to control land subsidence, which can have a severe impact on roads, water and gas pipelines, buildings, and water-bearing strata. Although subsidence can occur during underground mining, as wher longwall methods are employed, it poses a potential threat many years after a room-and-pillar mine has been abandoned because the pillars left to support the overlying strata can deteriorate and collapse. To help pay the costs of reclaiming land and water resources affected by past mining operations, the Act imposes fees on coal production at both surface and underground mines. Companies pay 35 cents per ron of coral mined by surface methods, 15 cents per ton mined underground, 
and 10 cents per ton of lignite. (These fees were extended through the year 2004 by the Energy Poltcy Act of 1992.) The 1977 Act also provides funds to control fires in abandoned underground mines. Such tíns can travel long distances, fueled by coal remaining in the abandoned workings, and endanger life and property in communities situated above the buming area.

Waste piles from mining and coal preparation and from coal-fired power plants can also create environmental problems. They are regulated by the Resource Conservation and Recovery Act of 1976, the principal law governing the disposal of solid wastes. However, much of the material piled up during surface mining is used during reclamation, when soil and other materials are replaced to reflect natural conditions.

The impact of mining and coal preparation on water quality is controlled by the Federal Water Pollution Control Act of 1972, which has been incorporated into the Clean Water Act of 1977 and its amendments. One of the environmental consequences of coal mining is acid mine drainage, which contains sulfuric acid produced when pyrite and other iron sulfides react with ait and water. The acid water increases the solubility of toxic heavy metals, such as arsenic, lead, and mercury, and renders the water toxic to aquatic life and unfit for domestic and municipal use. Acid mine drainage can be reduced by a variety of methods, such as adding alkaline minerals to neutralize the acidity, sealing abandoned underground mines, controlling drainge, and constructing wettands with cattails, mosses, and other plants to clean the mine water.

When coal is burned, the sulfur in it is converted mostly into sulfur dioxide. In addition, ritrogen oxides are produced from nitrogen in the coal and the air used in conbustion, and ash is produced from inconbustible material. In the atmosphere, sulfur dioxide and nitrogen oxides are converted to sulfuric and nitric acids, which can react with rain or snow to produce acid rain. Most of the ash produced at coal-fired powered plants is in the form of powder-like particulates called "fly ash," which are carried in the flue gas. Fly ash is composed mainty of silica and alumina, ard may contain potentially hazardous trace elements. The remaining ash is bottom ash, or boiler slag, which is collected at the bottom of the boiler or fumace.

Sulfur dioxide emissions are usually controlled by the techrique of "flue gas desulfurization," generally with the use of "wet scrubbers." These spray the flue gas with a mixture of water and lime or limestone, which combines with sulfur dioxide to form a siudge. With the less common "dry scrubbers" a sinilaz spray produces a dry residue. The level of ritrogen oxides emissions usually is controlled by reducing the anount of air used during combustion and by lowering combustion temperatures. Particulates can be removed from flue gas by mecharical devices, but electrostatic precipitators and baghouses are more efficient. With electrostatic precipitators, the most common device in power plants, the particulates are electrically charged and coflected on metal plates. In baghouses, powerfu] fans draw the flue gases through an array of fabric filters that trap the particulates.

To maintain air quality, emission levels for sulfur dioxide, nitrogen oxides, and particulates have been established by the New Source Performance Standards of the Clean Air Act of 1970 and its amendments. Electric utilities and other industrial coal consumers built before 1971 are subject to emission controls set by the States and approved by the Environmental Protection Agency. Those built after 1971 must meet the following Federal limits, in pounds per million Btu: sulfur dioxide, 1.2; nitrogen oxides, 0.7; particulates, 0.1 . Electric generating units constructed or modified after September 1978 are subject to the more stringent standards of the Revised New Source Petformance Standards. These are based on the level of uncontrolled emissions and defined in terms of percentage reductions. A minimum of 70 percent reduction is required for coal with a low-sulfur content, and a 90 percent reduction for coal with a high-sulfur content. The emission rate for sulfur dtoxjde under the new standards range from 0.6 to 1.2 pounds per million Btal. For nitrogen oxides, the standards range from 0.5 to 0.8 pound per million Btu, depending on the rank of coal burned and the method of combustion. The limit for particulates is 0.03 pound per million Btu. The emission standards for industrial boilers constructed or modified after June 1986 are similar to those for electric generating units.

In November 1990, the Clean Air Act was amended to strengthen the National commitment to improve air quality. The new legislation establishes as a goal for the year 2000 a reduction in annual suifur dioxide enissions of at least I0 million tons from the 1980 level. Total sulfur dioxide emissions from all power plants will be limited to 8.9 million tons annually. The reduction will be in two phases. In Phase I January 1 , 1995, through 1999), the 110 largest sulfur-emitting power plants will be allowed to emit an average of 2.5 pounds of stilfur dioxide per million Btu of heat input. in Phase II, beginning in 2000, these plants and almost all others will be requited to reduce sulfux dioxide emissions to 1.2 pounds per milion Btu. 


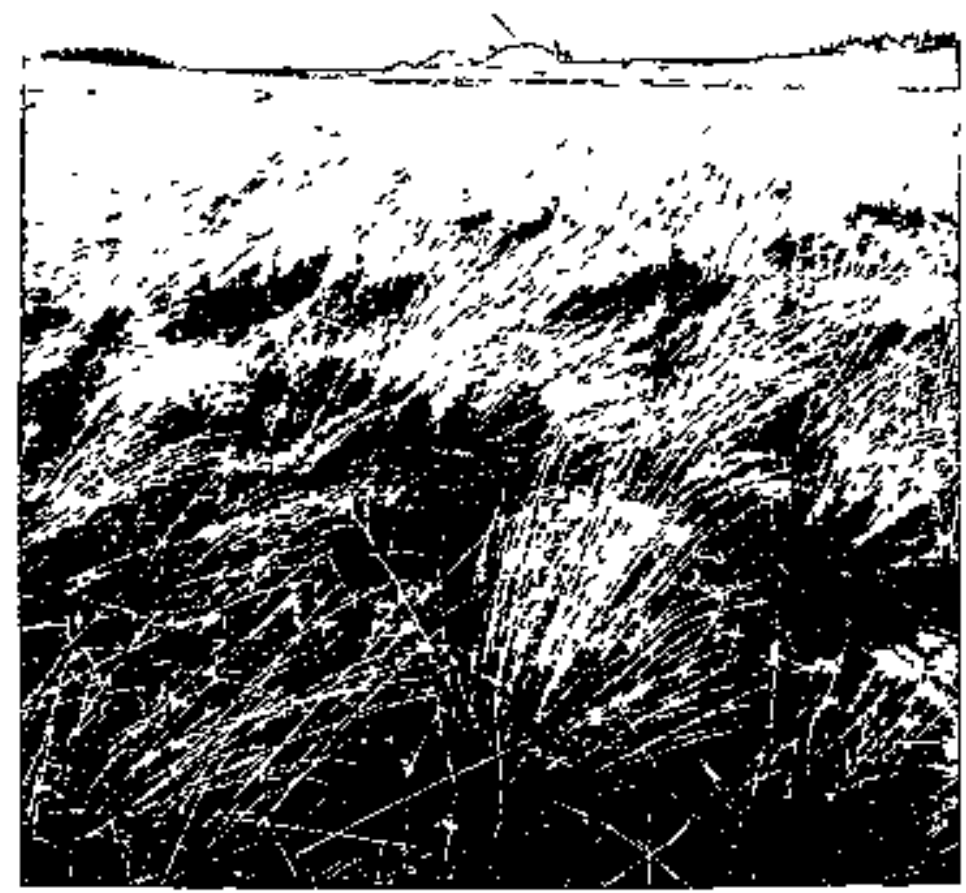

Near Colstip, Montane, mined fand has been reclaimed for Nvestock grazing es mining continues in the backgupundt.

One of the major breakthroughs in the 1990 Clean Air Act is a permit program for power plants that release pollutants into the air. The Environmental Protection A gency issues arunual allowances to power plants, with each allowance permitting 1 ton of sulfur dioxtde to be released from the smokestack. Plants ray release only as much sulfur dioxide as their allowances cover. If a plant expects to release more sulfur dioxide than it has allowances, it has to get more allowances. It can buy them from another power plant that has reduced ifs sulfur dioxide emissions, due perhaps to switching to Iow-sulfur fuel or installing scrubbers, and therefore has allowances to sell or trade. Allowances can also be bought and sold by "middlemen," such as brokers, and can be traded and sold nationwide. The program provides bonus allowances to power plants for, among other things, installing clean coal technology that reduce sulfur dioxide emissions, using renewable energy sources, or encouraging energy conservation by customers. The new legislation also requires a reduction of nitrogen oxides by 2 million tons. EPA will establish new limits for emissions of ritrogen oxides. All power plants under the program will have to install continuous emission monitoring systems to keep track of the amount of sulfur dioxide and rifrogen oxides released into the atmosphere.

Since passage of the Clean Air Act in 1970, billions of dollars have been spent by the Nation's utilities to reduce emissions of stlfur dioxide. Because of this huge invesinent, the Natton's air is cleaner today than it was about two decades ago. Emissions of sulfur oxides (comprised principally of sulfur dioxide) from all coalburning sources are responsible for abouk three-fourths of total sulfur oxide emissions. However, between 1970 and 1992, coal-generated enissions have fallen by about Il percent even though coal consumption increased by 70 percent. The decline reflects not only a greater number of planks meeting air quality standards through an increased use of scrubbers, but also a drop in the average sulfur content of coal bumed.

Also of environmental concem are emissions of carbon dioxide from coal combustion and of methane from coal mines, although controls on the emission of these gases from the use of coal and other fossil tuels have not been imposed. Both carbon dioxide and methare are major greenhouse gases and may contribute to global warming.

The arnount of carbon dioxide emitted when coal is bumed varies widely, depending on the rank of coal and the State in which it is protuced. Potential carbon dioxide emissions from the combustion of bituminous coal, the leading rank of coal consumed, average 205 pounds per million Btu, but range from 201 to 212 pounds per million Btu. By comparison, the average for subbituminous coal, the second leading rark of coal consumed, is 212 pounds per million Btu, while it ranges from 207 to 214 pounds per million Btu. The emission factor averages 216 pounds per million Btu for lignite and 227 pounds per million Btu for anthracite. 
Estimates of carbon dioxide emissions from coal combustion must take into account the "mix" of coals received from various sources. A voluntary program for companies to report reductions in gas emissions to the Energy Information Administration was among the provisions of the Energy Policy Act of 1992. The Act addresses many energy-related issues, including the attainment of higher energy efficiency standards and the environmentally sound use of fossil fuels.

Methane emissions occur mostly during production in underground mines. Bituminous coal generally emits more methane than the lower rank coals such as lignite. The amount of methane contained in a coalbed increases with depth. Small amounts of mettane can also be released when coal is transported and when it is pulverized for combustion.

\section{Coal Outlook}

The Nation's abundant coal reserves are expected to continue as an important sourse of energy in the foreseerble future. Annual coal production is projected to remain around 1 billion tons into the next century. Nearly 90 percent of this is projected to be for domestic consumption, principally to generate electricity. The rest of the output is expected to be exported.

Research and development are underway to make coal a more competitive and cleaner-burning fuel, as well as a greater source of chemicals. All parts of the "coal chain" are being investigated, from mine to consumer. Both Federal and State pollution control regulations are giving impetus to the coal industry's effort to produce a clearer, more efficient fuel.

Computer-assisted mining systems under development have the potential to advance mining technology through automation, robotics, and networking programs that can monitor a variety of mining activities, resulting in improved health, safety, productivity, rellability, and economy. Equally important are studies concerned with the human factors involved in coal mining.

Although mining ditsrupts the land for a period of time, considerable progress has been made in reclaiming mined land. This includes the restoration of the land surface, the rehabilitation of soil materials, and revegetation. The goal of reclamation is to restore the mined land to its original use or enable jt to be put to another use.
Advanced coal preparation, geared to inproving current state-of-the-art techniques, could remove as much as 90 percent of the sulfur and ash from the coal, improving its burning and environmental qualities. This can be accomplished by usting sophisticated physical, chemical, and biological methods to demen finely ground coal. The removal of sulfur not associated with mineral impurittes and of alkali metal impurities in western coals are challenging goals, because these elements are generally bonded to the organic coal mitrix, requiring the use of chemical reagents. Innovative approaches to future coal preparation could include use of microwave and microbial and enzymatic techriques.

Drying techniques are being developed to lower the moisture content in western coals (30 percent is not uncommon). When dried, low-rank coals typically cnumble and become very dusty. New drying methods will produce solid pellets of coal that have about twothirds less moisture and about one-third more heating value. This dried coal can be blended with raw subbituminous coal or ligrite to raise the overall heating value, or with high-sulfur coal to reduce sulfur emisslons.

Traditional coal-burring methods will continue to be used for mary years. However, clean coal technology -a term that entered the energy vocabulary in the 1980 's-offers the potential for a cleaner environment and lower power costs. Included are more effective precombustion coal-cleaning processes, such as methods for keeping sulfur and nitrogen pollutants inside the furnace and scrubber systems capable of removing pollutants in the form of dry solid waste, reducing the disposal problems created by wet sludge. Some clean coal technologies depart from conventional coal* burning methods in that the coal is converted into a gas or liguid that is used as fuel.

Advanced pulverized coal technologies can take pulverized coal combustion- the most widely accepted tecturolegy for conl-fired power generation-one step further, by refiring the process to gain major improvements. Included are low entission botler systems, which incorporate enission controls at the outset of design and development insted of adding them to a cont pleted system, and cogeneration, which produces both steam and power for power generation and also heat for process and space heating, and can result in improvement in plant efficiency of over 70 percent.

Coal gasification, an old technology that is being nodernized, converts coal into a gaseous product by heating it with stem and oxygen or air. The gas 


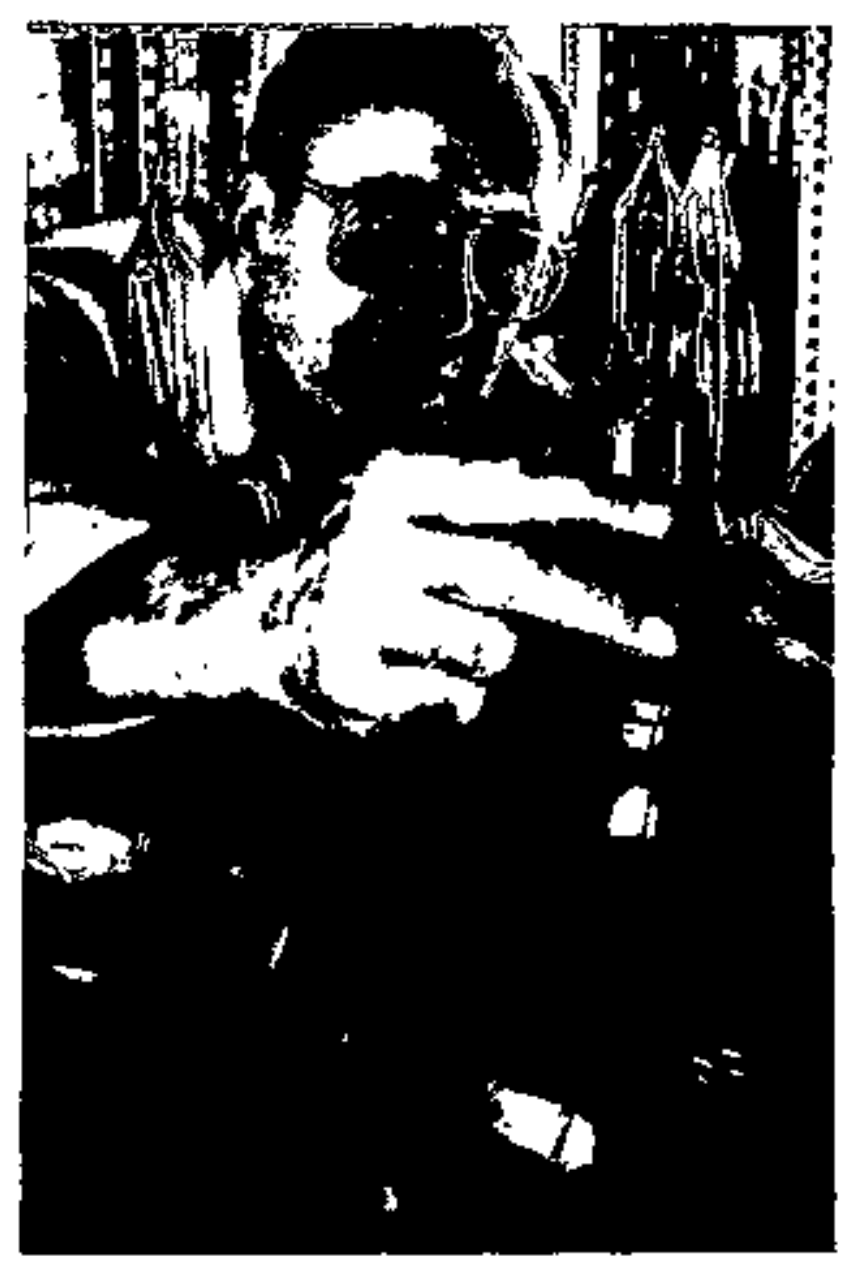

Pristine coal samplos are thed by reseanchers investlgating cheaner and more efficlent colat use.

produced can be cleaned and used as a fuel or processed further to produce synthesis gas. Synthesis gas (mostly carbon monoxide and hydrogen) can be converted to a substitute for natural gas, chemicals, or liquid fuel. The amount of gas that car be produced from a ton of bituminous coal depends on the technology used and ranges from about 15,000 cubic feet of high+Btu gas (about 1,000 Btu per cubic foot) to 7,000 cubtc feet of low-Btu gas (up to 200 Btu per cubic foot). In 1993, three coal gasification plants were in commercial operation in the United States. The Great Plains Synfuels Plant, near Beulab, North Dakota, operated by the Dakota Gasification Company to convert lignite into pipeline-quality gas, obtaining chemical byproducts as part of the process. Tennessee Eastman Company's coal gasification plant in Kingsport, Tennessee, converted bituminous coal into chemicals. At Plaquenine, Louis jaria, subbihuminous coal was converted by Lotuisiana Gesiffcation Tectunology into gas for use in generating electriciky and otuperheated oteam for an adjacent chemical complex.
Coal gasification also has potential in development of fuel cells, which generate electricity from the reaction of hydrogen and axygen. Currently, most tuel cells approaching commercialization are fueled with natural gas. Because hydrogen is produced in coal gasiftcation, coal gasifiers could be integrated into future fuel cell technologies to provide a new approanh to power generation.

The research and development of "mild gasification" is ained at processing coal tnder lower temperatures and pressures than in a typical coal gasification process. This leads to the production of liquids and solids that can be upgraded into high-value industrial raw material and chemical feedstock, in addition to gas, which can be used to provide heat for the process.

Underground coal gasiffcation is the technology of converting coal to gas without mining. Wells are drilled into a coalbed, which is ignited and encouraged to burn. The burning coal generates combustible gases that 
can be collected at the surface for use as fuel or as feedstock for producing chemicals, such as ammonia and urea. The Federal Goverrment has sponsored underground gasification tests in Wyoming, West Virginia, and Washingtor.

Coalbed methane, a danger to mining, is a potentially important source of energy. It is currently produced in sore States (principally Alabama, New Mexico, and Wyoming) to supplement the supply of natural gas, which is composed largely of methane; its potential is being evaluated in other States. Methane can be produced from unmined beds or in advance of mining a coalbed. Degasification of a coalled not only supplies a useful product, but also provides a safety measure because it reduces the amount of methane released into the working areas of a mine.

Coal liquefaction, another old technology, converts cosl into liquid fuels by three techntquest indirect, direct, and pyrolysis. With an indirect process, coal is first gasified, and then the coal-derived synthesis gas is converted into a variety of liquid fuels, such as methanol, gasoline, diesel fuel, and octane enhancers. The best-known indirect coal liquefaction facilities are operated in South Africa by South African Coal, Oil and Gas Corporation, Ltd. (SASOL), which produces a range of bquid fuels including gasoline, dhesel oil, and jet fuel. With a direct coal liquefaction process, finely ground coal in a solvent is mixed with hydrogen and heated to a high temperature under high pressure to produce "synthetic crude oil." This can be upgraded into higher quality fuels by further processing with existing petroleum-refining techniques. With pyrolysis, dry coal is subjected to high temperatures in a chemically reducing atmosphere to produce a heavy synthetic crude oil, which can be refined, and char, a solid residue that can be used as a fuel. Depencing on the process used, a ton of binwinous coal can be converted into 0.5 to 3 barrels (21 to 126 gatlons) of liquid fuel.

Solvent-refired coal processes produce a low-ash, lowsulfur fuel from coal high in both ash and sulfur by dissolving pulverized coal in a solvent. The final form of the fuel, whether a liquid or a solid, is determined by the process used.

Mixtures of finely ground coal and oil or water can be substituted for fuel oil in oilturning facilities. They have the advantage of being transported, stored, and burned in a manner similar to fuel oil By weight, coal constitutes 40 to 50 percent of coaloil mixtures and about 70 percent of coal-water mixtures; some chemicals are added to the mixtures to prevent the coal particles from settling out in storage. The technology for producing coal-liquid mixtures has been broadened to include methanol and solvent-refined coal. The idea of using coal-oil mixtures is not new. They were tested in the 1930's as an oil substitute for ships in transAtlantic service, and in the 1950's they were evaluated as fuel for blast fumaces. The potential of using coalwater mixtures was first demorstrated at a U.S. power plant in 1961. More recently, mixtures of coal and recycled paper have been tested on a small scale for use as fuel.

Direct coal-fired heat engines represent another aspect of clean coal tecturologies. They include direct coal-fired gas turbines, which involve the use of both a coal-water slurry and dry pulverized coal, and direct coal-fited diesels, which involve the development of diesel engines that will bum a coal-water slumy rather than distillate petroleum fuels.

Fluidized-bed combustion, a technology dating back to the early 1920 's, is well-suited for burning high-sulfur and low-quality coals in an environmentally acceptable marner. It has become commercially competitive for large industrial applications and is currently used to generate electricity. With this technology, crushed coal is burned on a bot tubulent bed of limestone or dolomite, which absorts most of the sulfur dioxide produced. As a result, the need for flue gas desulfur* ization units is eliminated. Only a small anount of ritrogen oxides is produced because of relatively low combustion temperatures. The fluidized-bed units in operation bum coal under normal atmospheric pressures. Advanced units under development-pressurized flufdized-bed combustion systems-operate at higher pressures to achieve greater efficiency.

Formcoke is of potential importarce as a blast fumace fuel. It is made by heating bricuettes of finely puivertzed coking coal or other coal, including some subbituminous coals, that has been carbonized to obtain a char, which is further carbonized to produce metallurgical coke. Although pulverized coal is being used in blast furnaces, replacing some of the coke, a clean coal tectrology project entitled "blast furnace granulated-coal injection system ${ }^{n}$ involves retrofiting blast furnaces with technology to operate with a variety of coal particle sizes. Also ander development is COREX (Coal/Ore Reduction), a novel "cokeless" ironmaking process in which coal can be substikuted for coke in a spectal fumace to smelt iron ore. It could replace the conventional two-step coke oven/blast furnace procedure for producing pig iron, eliminating the environmental problems associated with coke 
making. Sulfur in the coal is captured in the by-product slag.

Magnetohydrodynamic (MHD) conversion is a potential method of burning coal cleanly and at high effictiencies to generate electricity. MHD systetns differ from other advanced coal-fired systerts in that coal is bumed at very high temperatures to produce ionized combustion gases that pass through a magnetic field to create electricity. Lnked with a conventional steam turbinegenerator, commercial MHD systems are expected to achieve power generating efficiencies of well above 50 percent-more than one-and-a-half times those of conventional coal-buning power plants.

As the complex nature of coal becomes better understood, it could once again become important as a raw material for manufachuring a variety of chemicals. Many of the organte chemicals made today from petrolewn were originally by-products of the cokemaking process. With the development of sophisticated chemical processes, coal-derived chemicals could provide the building blocks for making special products, such as carbon fibers, composite matertals, and fullexenes (a form of carbon discovered in 1985 that has possible applications in high-temperature lubricants, microfilters, more efficient superconductors, and gas adsorbents).

All these and other applied research efforts are being supplemented by fundamental studies of the atomic and molectular structure, composibion, and charactex- istics of coal. Suct work provides the besic information that enables practical research to succeed.

The U.S. Department of Energy (DOE) is investing in a Clean Coal Tecinology (CCT) Demonstration Program, a goverminent-industry co-funded effort to develop new technology with the dual goals of attaining environmental quality and energy security from coal. The CCT program, which started in 1986, is conftined to perfecting the early stages of Jong-term, high-risk research that tindustry is reluctant to pursue. At the end of 1993, the program comprised 45 demonstration projects either underway or completed in 21 stakes, representing nearly $\$ 2.5$ billion in Federal fumding and more than $\$ 4$ billion in cost-sharing from private and State sources. DOE also furds coal projects at U.S. colleges and universities. Since 1979, DOE's University Coal Research Program has provided $\$ 76$ million for fundamental studies of coal and coal-related topics.

Looking ahead, there is little doubt that the United States has the resources to remain self-sufficient in coal well into the 21st century. The Nation has enormous coal reserves, a well-developed coal industry, and advancing coal technologies. The U.S. coal industry continues to adjust to chantges in economic conditions, govenunental actions, and envitonmental constraints that influence the production and use of coal. As a producer of an important source of energy, the coal industry will continte to directly or indirectly touxh on almost every phase of our daily lives. 
, 


\section{Supplemental Figures and Tables}

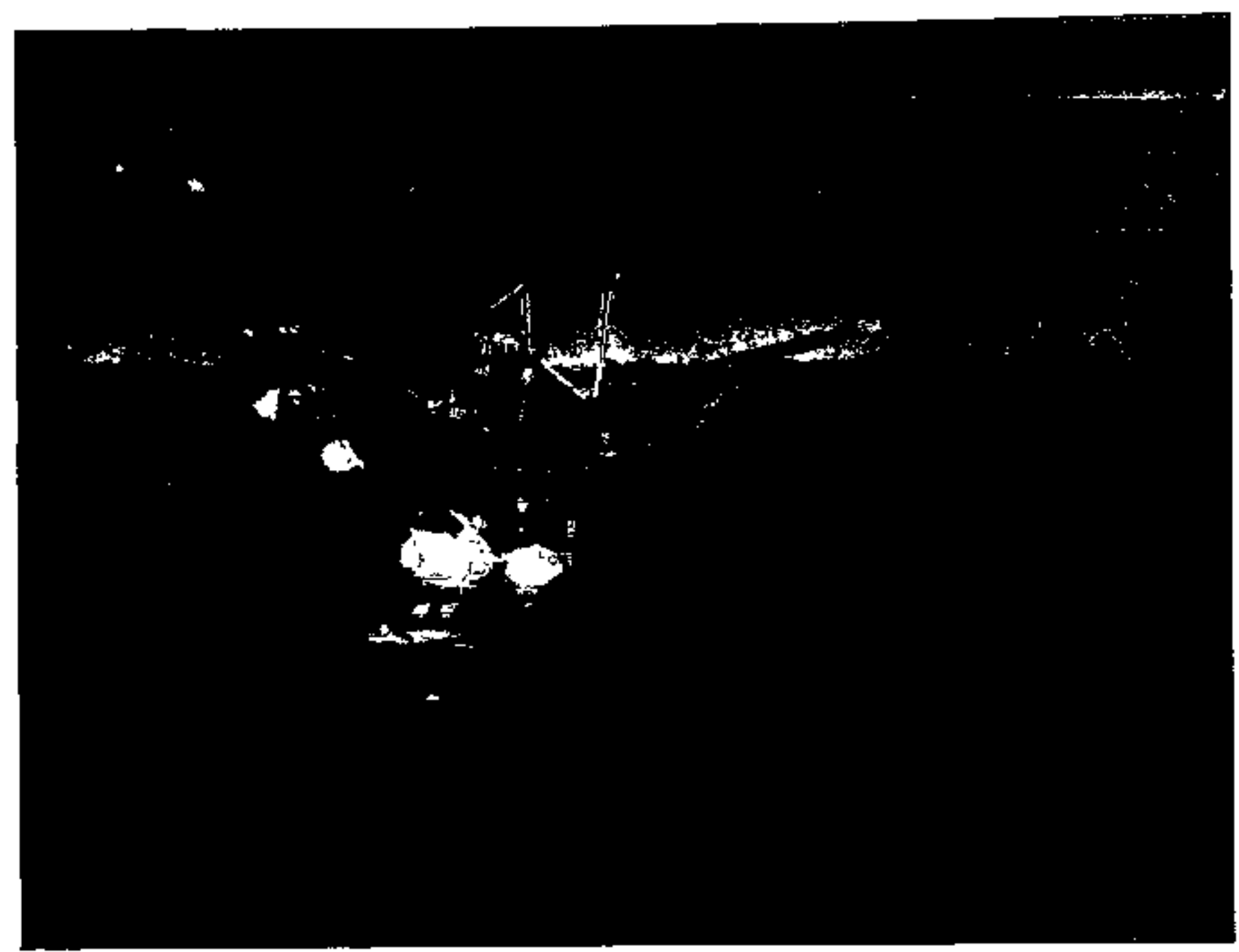

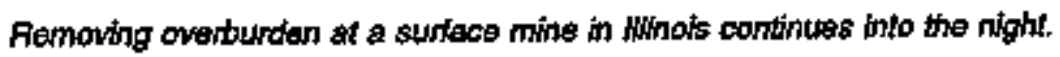


Figure 17. Selected Developments in the History of U.S. Coal Since 1810

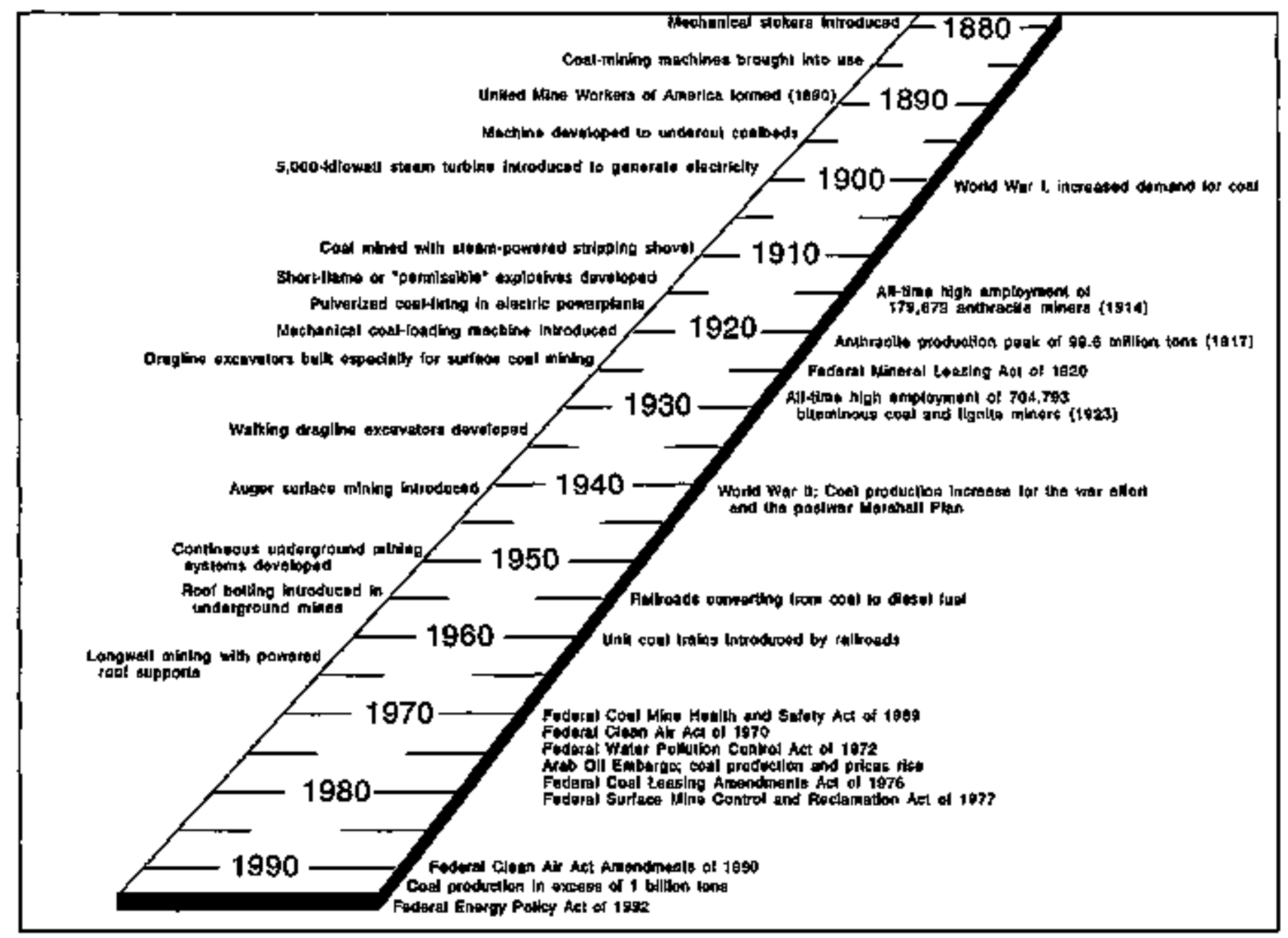


Figure 18. Esthmates of Recoverable Coal Reserves by BtwSufur Ranges and Region, January 1, 1992

(Binlion Short Tons)

\section{Sulfur Content}

(Pounds per Million Biu)

ए. $\geq 1.68$ (High Sulfur)

[.]- $\quad 0.61=1.67$ (M)dlum Suftur)

$\square$ - $\leq 0.60$ (Low Sulfur)
148,4

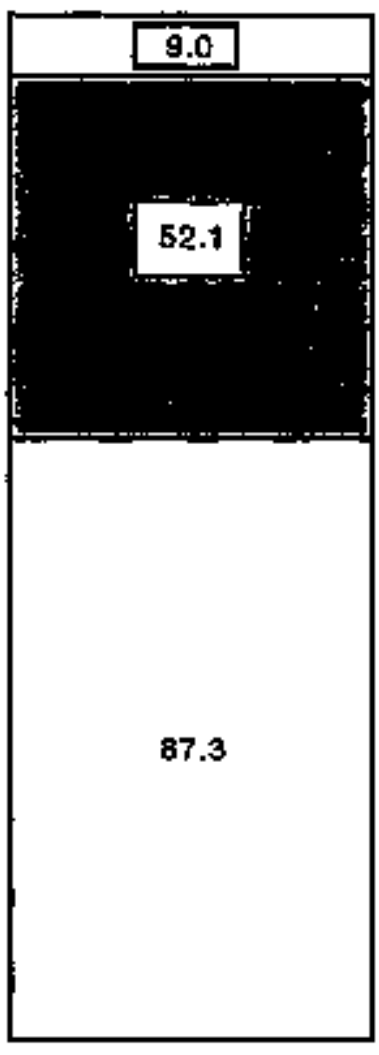

Westem

Source: Energy Informatton Adminlalration, U.S. Coel Fesenves: An Update by Heat and Stifur Content, DOE/EIA-0629(92) (Weshington, DC, February 1993). 
Table 8. U.S. Demonstrated Reserve Base of Coal by Potential Mining Wethod and Ranked by State Total, January 1, 1993

(Million Short Tons)

\begin{tabular}{|c|c|c|c|}
\hline 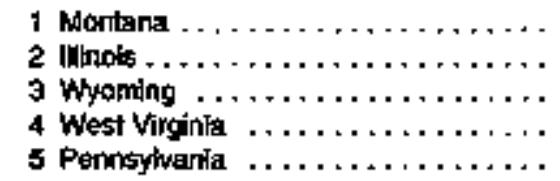 & $\begin{array}{l}70,959 \\
62,638 \\
42,585 \\
31,819 \\
24,562\end{array}$ & $\begin{array}{r}49,912 \\
15,369 \\
26,524 \\
4,679 \\
4,510\end{array}$ & $\begin{array}{r}119,870 \\
78,007 \\
69,059 \\
36,499 \\
29,071\end{array}$ \\
\hline 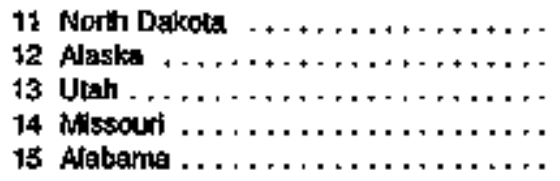 & $\begin{array}{r}0 \\
5,423 \\
5,770 \\
1,479 \\
1,422\end{array}$ & $\begin{array}{r}9,550 \\
711 \\
268 \\
4,518 \\
3,296\end{array}$ & $\begin{array}{l}9,550 \\
6,134 \\
6,047 \\
5,998 \\
4,718\end{array}$ \\
\hline 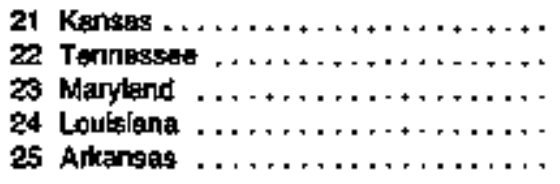 & $\begin{array}{r}0 \\
551 \\
660 \\
0 \\
273\end{array}$ & $\begin{array}{r}976 \\
291 \\
84 \\
480 \\
145\end{array}$ & $\begin{array}{l}976 \\
842 \\
744 \\
490 \\
417\end{array}$ \\
\hline 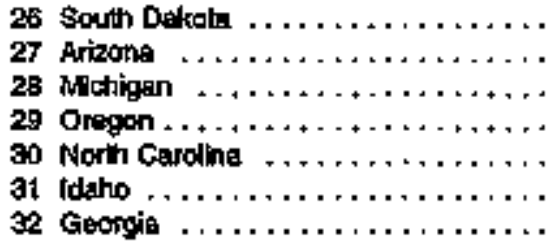 & $\begin{array}{r}0 \\
102 \\
123 \\
15 \\
11 \\
4 \\
2\end{array}$ & $\begin{array}{r}336 \\
119 \\
5 \\
3 \\
0 \\
0 \\
2\end{array}$ & $\begin{array}{r}366 \\
290 \\
128 \\
18 \\
11 \\
4 \\
4\end{array}$ \\
\hline
\end{tabular}

Note: Totals may not equal sum of cormponents because of independent rounding.

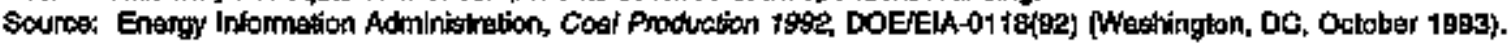

Table 9. Estimates of U.S. Recoverable Coal Reserves by Bhu/Sulfur Content and Region, 1992 (Million Short Tons Rernalning as of January 1, 1992)

\begin{tabular}{|c|c|c|c|c|}
\hline Ferpan & $\begin{array}{c}5.60 \\
\text { (low solfor) }\end{array}$ & $\begin{array}{c}0.61-1.67 \\
(m i n t i m \text { sulfur) }\end{array}$ & 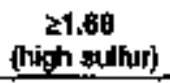 & Totol \\
\hline 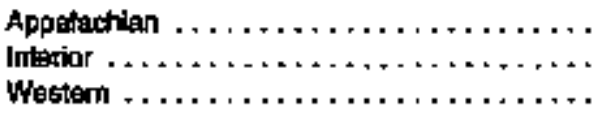 & $\begin{array}{r}12,291 \\
548 \\
97,332\end{array}$ & $\begin{array}{l}20,297 \\
11,970 \\
52,008\end{array}$ & $\begin{array}{r}22,558 \\
48,693 \\
3,959\end{array}$ & $\begin{array}{r}55,086 \\
61,210 \\
148,386\end{array}$ \\
\hline
\end{tabular}

Nole: Totals may not equel sum of components due to Independent rounding. Btu = Bitioh themal tintt

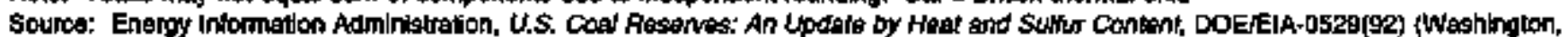
DC, Fotantery tges]. 

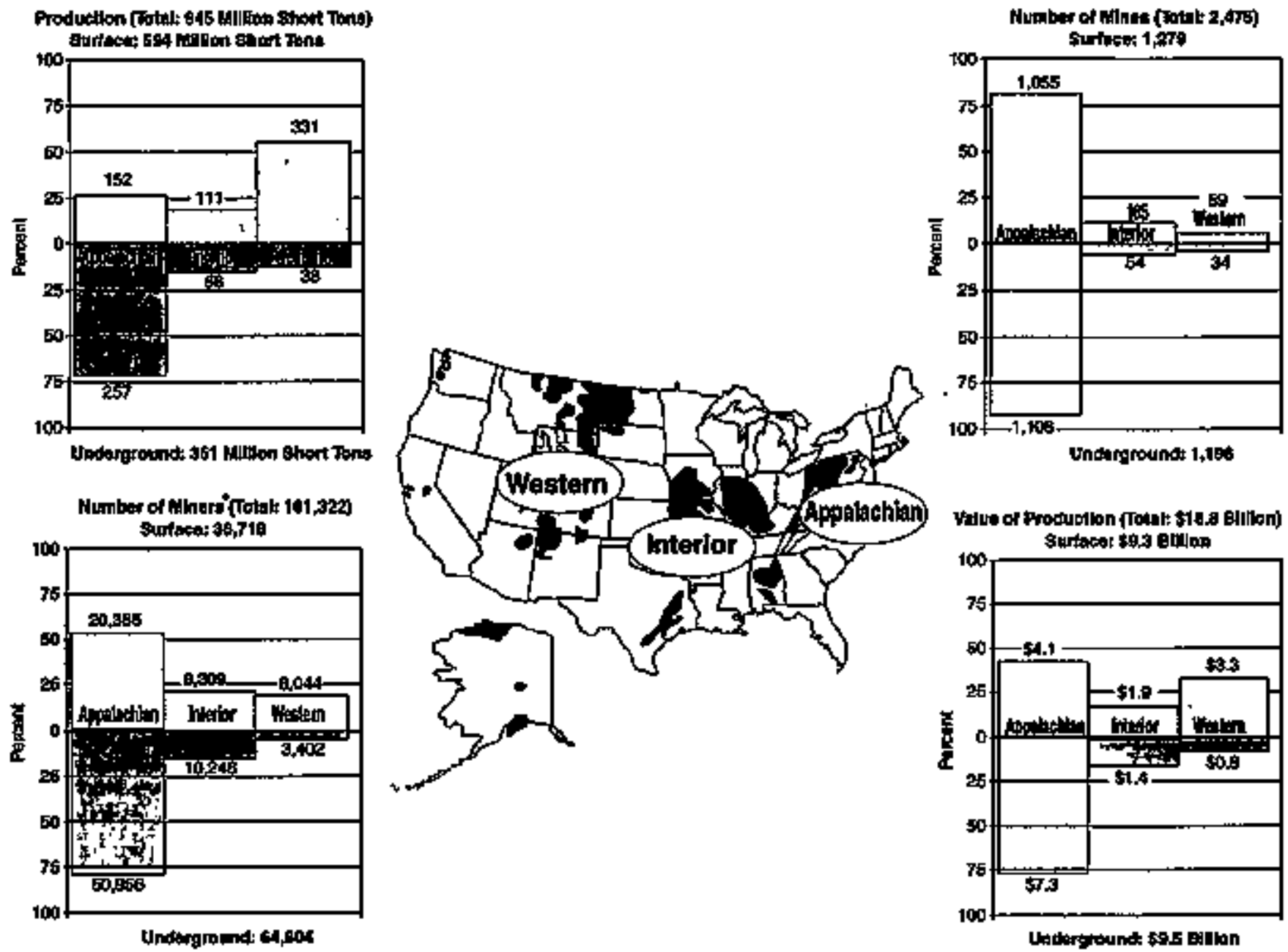

At mines that produced 10,000 or mare shart tons.

The Appatachian Ragian is the Netion's principle source of coal. in 1993, if accounted for atmost hall of the total output, most of the mines and miness, and more than haff of the totad values of the caal protuced.

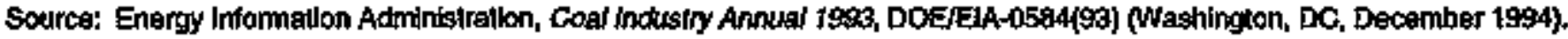


Figure 20. U.S. Production of Energy by Solures, 1960-1993

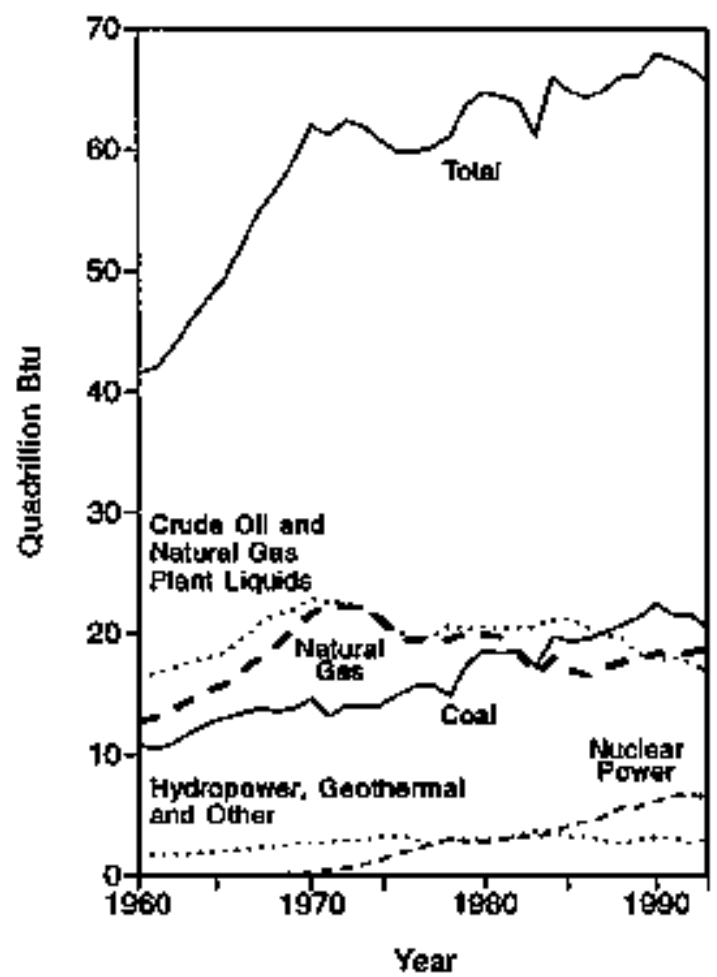

Source: Energy [niormation Adminisiration, Annual Energy Aeview 1993, DOE/EA-0384(93) (Washington, DC, July 1994).
Figure 21. U.S. Consumption of Energy by Source, 1960-1993

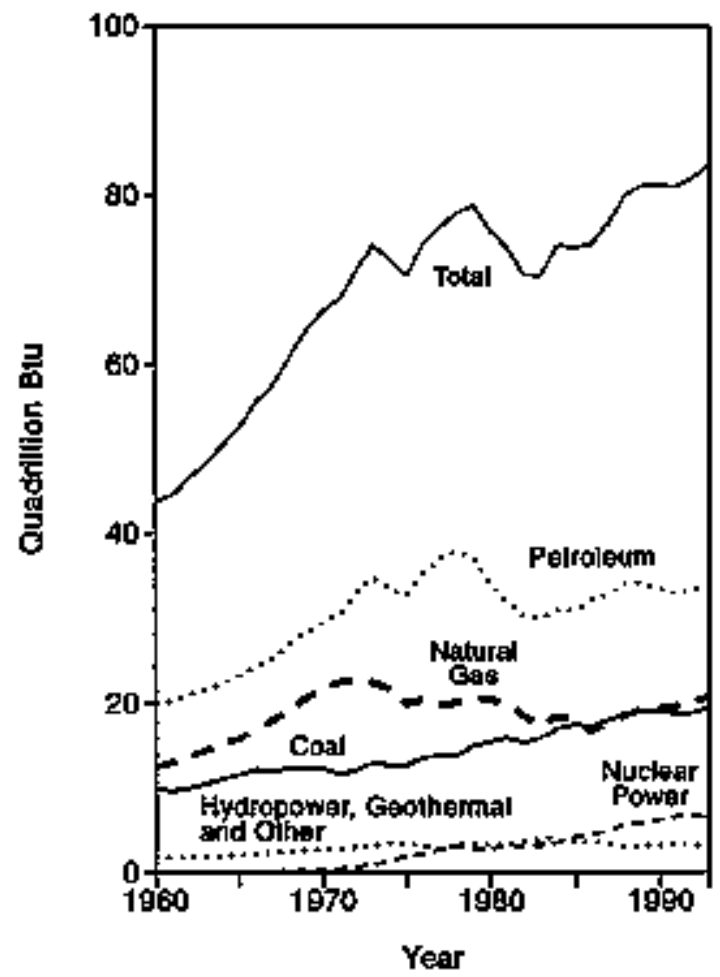

Source: Energy Information Administration, Annual Energy Bevew 1993, DOEJELA-03B4(93) (Weshington, DC, July 1994). 
Figure 22. U.S. Coal Production by State, 1993

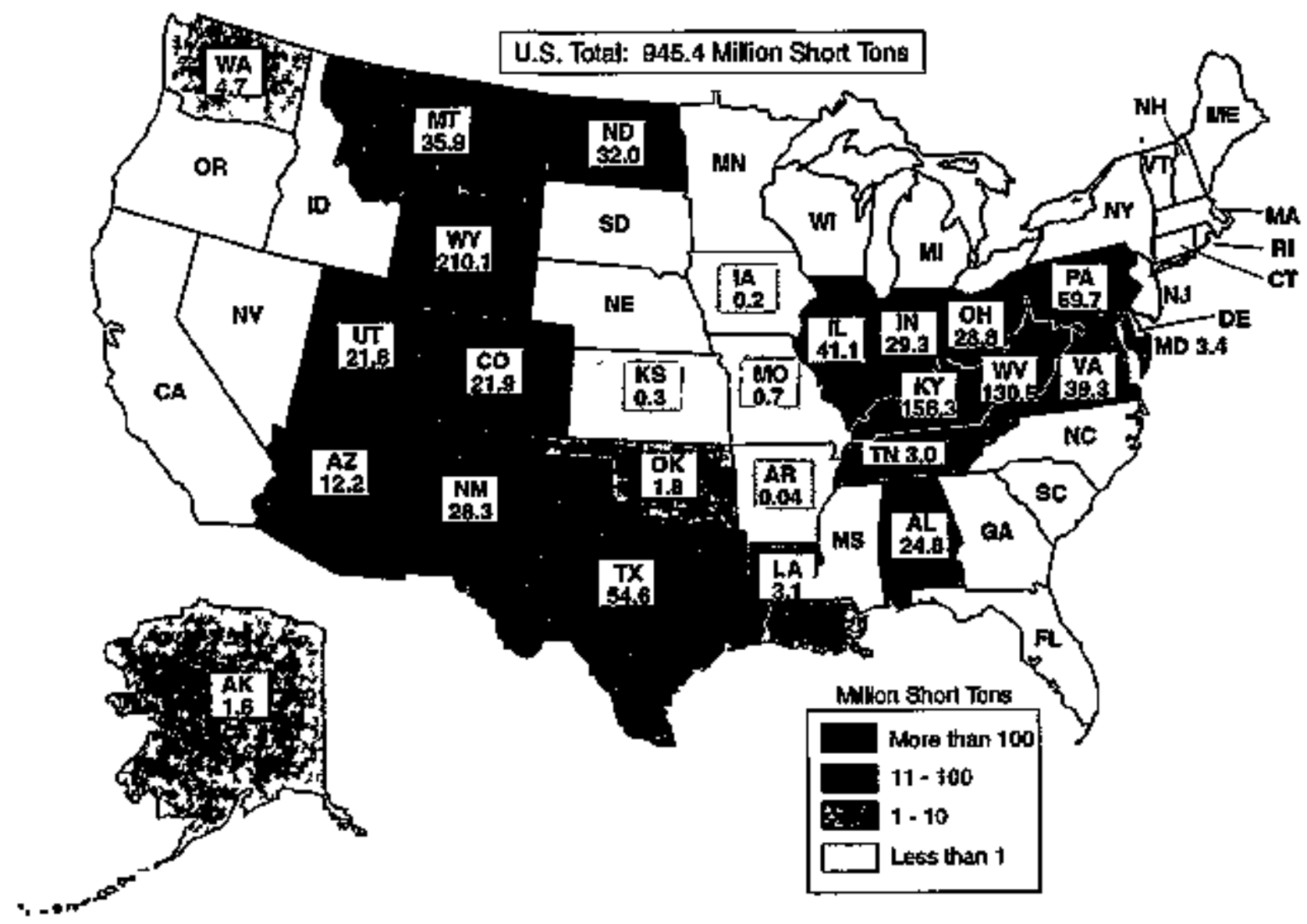

Of the 26 States with coat production in 1993, Wyoming. Kentuthy, and West Virginda predombated. Together, they accounted for about half of total production.

Note: States with no data did not proctuce coal.

Source: Energy Informalion Administration, Coal industry Annual r999, DOËEIA-0584(93) (Washington, DC. December 1994). 
Flgure 23, U.S. Coalproducing Counties in the United States, 1993

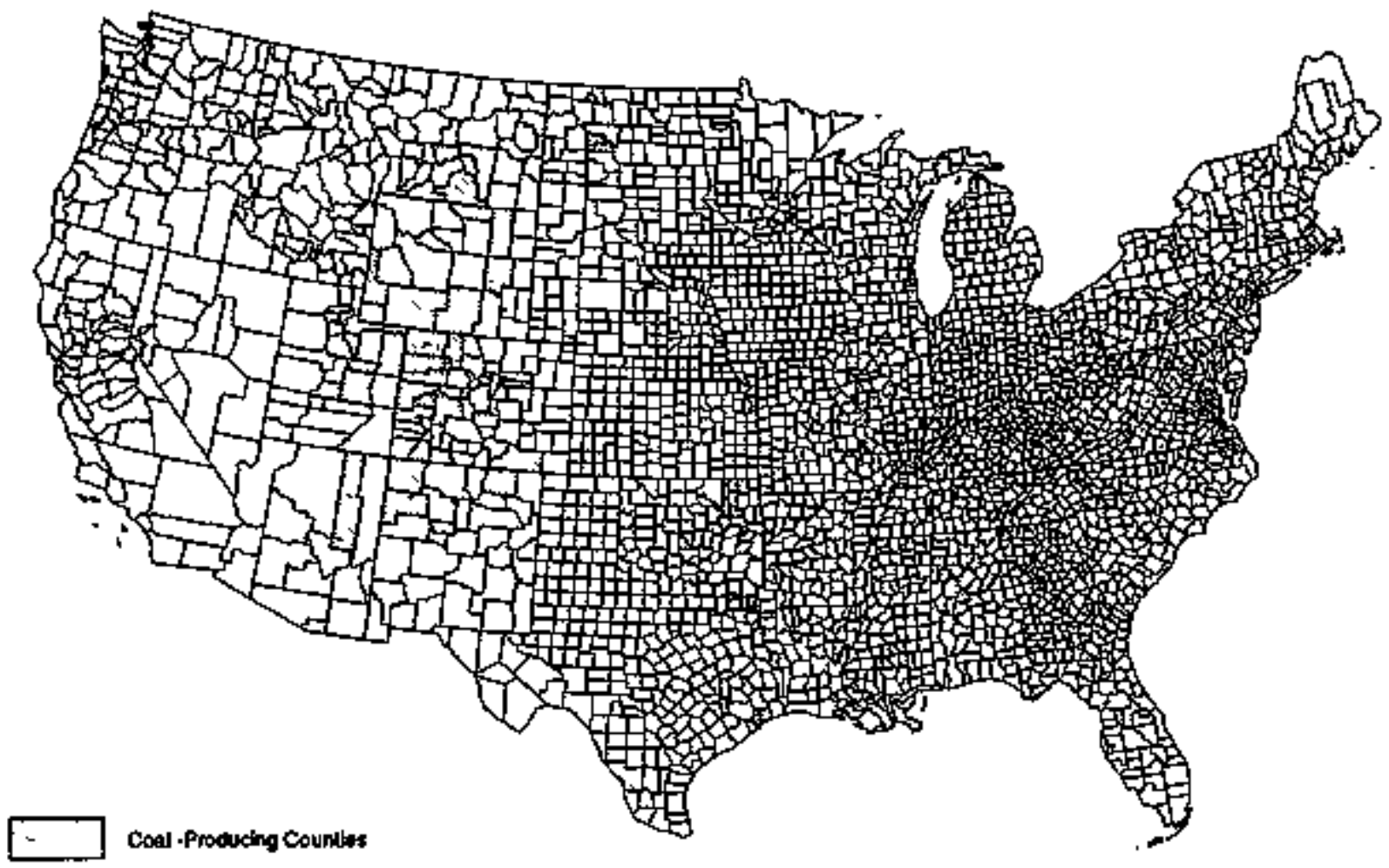

Note: There are no countie in Alaske. In 1993, coal was produced from one mine near Healy, south of Faktanks, in Yukon Fiver Borough.

Source: Energy Information Administration, Cosl indesty Annual 1983, DOEF'EAA-0684(93) (Washinglon, DC, Decernber 1994). 
Flgure 24. Average Number of U.S. Coal Miners by Type of Mining, 1998

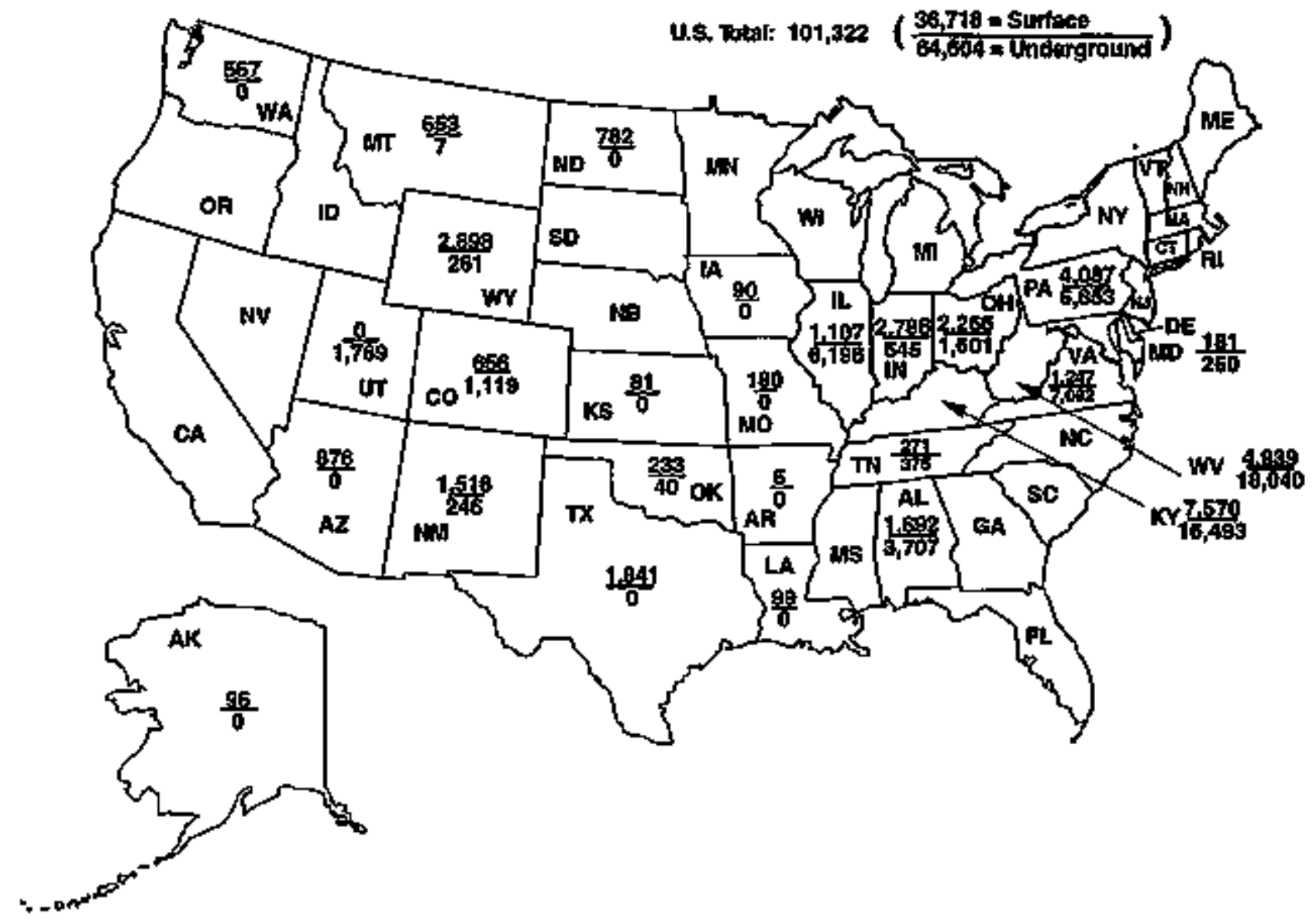

Nole: Average number of miners exckudes mines producing less than 10,000 short lons during the year. States with no data did not produce coal.

Source: Energy Information Admintsiralion, Coal industry Annuel 1993, DOEEElA-0584(93) (Washington, DC, December 1994). 
Table 10. U.S. Coal Production and Related Statistics, Selected Years, 1980, 1985, 1990-1993

\begin{tabular}{|c|c|c|c|c|c|c|}
\hline Cheracteristice of Coal Production & 1980 & 1985 & 1990 & 1991 & 1992 & $\$ 993$ \\
\hline \multicolumn{7}{|l|}{ Production (milion sthort tons) } \\
\hline \multicolumn{7}{|l|}{ Mining Malhod } \\
\hline Undarground $\ldots \ldots \ldots \ldots \ldots \ldots$ & 338 & $\$ 51$ & 445 & 407 & 407 & 351 \\
\hline & 594 \\
\hline Appaladitan $\ldots \ldots \ldots \ldots \ldots \ldots \ldots$ & 444 & 427 & 489 & 458 & 457 & 410 \\
\hline Interior $\ldots \ldots \ldots+\cdots \ldots \ldots$ & 176 & 188 & 206 & 195 & 196 & 167 \\
\hline Westem $\ldots \ldots \ldots \ldots \ldots$ & 200 & 269 & 334 & 343 & $\$ 45$ & 369 \\
\hline \multicolumn{7}{|l|}{ Federaly Administored Lands } \\
\hline Total $\ldots \ldots \ldots \ldots \ldots \ldots \ldots$ & 9s & 184 & 273 & 260 & 267 & 288 \\
\hline Fediera Coal Leasers . . . . . . . . . & 69 & 159 & 246 & 240 & 239 & 258 \\
\hline Indlan Coal Leases . . . . . . . . . + & 24 & 25 & 28 & 27 & 28 & 28 \\
\hline \multicolumn{7}{|l|}{ Coal Rank } \\
\hline Anthreacise $\ldots \ldots \ldots \ldots \ldots \ldots$ & 6 & 5 & 4 & 3 & 3 & 4 \\
\hline Biturititous $\ldots \ldots \ldots \ldots \ldots \ldots$ & 609 & 614 & 899 & 651 & 651 & 677 \\
\hline Subbiturinous . . . . . . . . . . . & 148 & 198 & 244 & 255 & 252 & 275 \\
\hline Lgrita . . . . . . . . . . . . . & 47 & 72 & BB & 87 & $\mathbf{9 0}$ & 90 \\
\hline \multicolumn{7}{|l|}{ Averase Value (dollass per shert ton) ${ }^{a}$} \\
\hline Total $\ldots \ldots \ldots \ldots \ldots \ldots \ldots \ldots$ & 24.65 & 25.67 & 21.76 & 21.49 & 21,03 & 19.65 \\
\hline Undergrournd $\ldots \ldots \ldots \ldots \ldots \ldots \ldots$ & 33.50 & 39.35 & 28.58 & 28.56 & 27.89 & 29.92 \\
\hline Surtace $\ldots \ldots \ldots \ldots \ldots \ldots \ldots$ & 18.73 & 20.59 & 16.98 & 16.60 & 16.34 & 15.67 \\
\hline \multicolumn{7}{|l|}{ Number of winesb } \\
\hline Tolal . . & 3,969 & 3,355 & 2,707 & 2,394 & 2,196 & 2,030 \\
\hline $\begin{array}{l}\text { Maling Melnod } \\
\text { Underground }, \ldots \ldots \ldots \ldots \ldots \ldots .\end{array}$ & 1,es 7 & 1,695 & 1,422 & 1,255 & 1,138 & 1,034 \\
\hline Surlace $\ldots \ldots \ldots \ldots \ldots \ldots \ldots$ & 2,082 & $1,6 \in 0$ & 1,285 & 1,139 & 1,058 & 996 \\
\hline \multicolumn{7}{|l|}{ Peglon } \\
\hline Appalachian $\ldots \ldots+\ldots \ldots+\ldots+$ & 3,499 & 2,952 & 2,377 & 2,071 & 1,099 & 1,743 \\
\hline 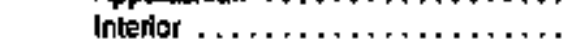 & 337 & 278 & 208 & 230 & 198 & 199 \\
\hline Westem $\ldots \ldots \ldots \ldots \ldots \ldots$ & 134 & 115 & 102 & 93 & 90 & 9日8 \\
\hline \multicolumn{7}{|l|}{ Large Mhines } \\
\hline Total $\ldots \ldots \ldots \ldots \ldots \ldots \ldots$ & 323 & 343 & 375 & 359 & 352 & 348 \\
\hline Underground $\ldots \ldots \ldots \ldots \ldots+\ldots$ & 170 & 186 & 190 & 180 & 179 & 162 \\
\hline Surlace $\ldots \ldots \ldots \ldots \ldots \ldots$ & 153 & 157 & 185 & 175 & 173 & 196 \\
\hline Percentage of Production ........ & 60 & 67 & 75 & 77 & 78 & 78 \\
\hline Longwall Alning Installations . . . . . . . & NA & 108 & 96 & 93 & 90 & 85 \\
\hline \multicolumn{7}{|l|}{ Employmenl (housands) d } \\
\hline Total $\ldots \ldots \ldots \ldots \ldots \ldots \ldots \ldots \ldots$ & 20 & 168 & 131 & 121 & 110 & 101 \\
\hline Undesground $\ldots \ldots \ldots \ldots \ldots$ & 151 & 107 & B4 & 78 & 71 & 65 \\
\hline$\underset{\text { Rexion }}{\text { Sufface }} \ldots \ldots \ldots \ldots \ldots \ldots$ & 76 & 62 & 47 & 43 & 39 & $\mathbf{3 7}$ \\
\hline Appolactian $\ldots \ldots+\ldots \ldots+\ldots+\ldots$ & 171 & 122 & 95 & 86 & 78 & 71 \\
\hline Intertor $\ldots \ldots \ldots \ldots \ldots+\ldots+$ & 40 & 32 & 23 & 22 & 20 & 50 \\
\hline westom $\ldots \ldots \ldots \ldots \ldots \ldots$ & 19 & 15 & 13 & 13 & 12 & 11 \\
\hline \multicolumn{7}{|l|}{ Productivity (short tons per mines houn) } \\
\hline Total $\ldots \ldots \ldots \ldots \ldots \ldots \ldots \ldots \ldots$ & 1.9 & 2.7 & 3.8 & 4.1 & 4,4 & 4,7 \\
\hline \multicolumn{7}{|l|}{ Mthing Melhod } \\
\hline Underground $\ldots \ldots \ldots \ldots \ldots \ldots$ & 12 & 1.8 & 2.5 & 2.7 & 2.9 & $\mathbf{3 . 0}$ \\
\hline Surkace,$\ldots \ldots \ldots \ldots \ldots \ldots$ & 3.2 & 42 & 5.9 & 6.4 & ต.ต & 7.2 \\
\hline \multicolumn{7}{|l|}{ Feggion } \\
\hline Appalactian $\ldots \ldots \ldots \ldots \ldots \ldots$ & 1.4 & 1.9 & 26 & 27 & 30 & $\mathbf{3 . 0}$ \\
\hline Interiar $\ldots \ldots \ldots \ldots \ldots \ldots \ldots$ & 2.3 & 2.8 & 3.9 & 4.0 & 4.2 & 4,4 \\
\hline Wastern $\ldots \ldots+\ldots \ldots \ldots \ldots \ldots$ & 5.6 & e.B & 11.8 & 124 & 12.7 & 13.6 \\
\hline
\end{tabular}

See kootrotes at ond of tabla. 
Table 10. U.S. Coal Production and Related Statistics, Selected Years, 1980, 1965, 1990-1993 (Continued)

\begin{tabular}{|c|c|c|c|c|c|c|}
\hline Cheracteriatice of Coel Production & 1990 & 19685 & 1990 & 1991 & 1992 & 1998 \\
\hline Fatallties $\ldots \ldots \ldots \ldots \ldots \ldots \ldots \ldots \ldots$ & 133 & 68 & 66 & 61 & 54 & 47 \\
\hline \multicolumn{7}{|l|}{$\begin{array}{l}\text { Average Casl Ouality } \\
\text { Proxiuction }\end{array}$} \\
\hline $\begin{array}{l}\text { Heal content (malion Bitu per shart lon) } \\
\text { Ltil'y Cad }\end{array}$ & 22.4 & 21.9 & 21.8 & 21.7 & 21.6 & 21.4 \\
\hline Heal content (million Biej per short lon) & 21.3 & 21.0 & 20.9 & 20.8 & 20.8 & 20.8 \\
\hline \multicolumn{7}{|l|}{$\begin{array}{l}\text { Average Coal Cuallty } \\
\text { Ulitly Cod }\end{array}$} \\
\hline $\begin{array}{l}\text { (percentege by welgini, } \ldots \ldots \ldots \ldots \ldots \\
\text { Ash content }\end{array}$ & 1.6 & 1.4 & 1.4 & 1.3 & 1.3 & 1.2 \\
\hline (percentege by weight) .......... & 11.1 & 10.0 & 8.9 & 8.8 & 9.7 & 9.6 \\
\hline \multicolumn{7}{|l|}{ Cost Dlsposition (million sthot lons) } \\
\hline \multicolumn{7}{|l|}{ Domestic Consumption } \\
\hline 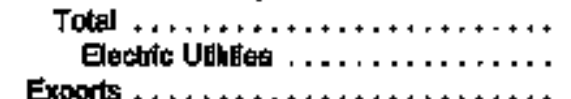 & $\begin{array}{l}703 \\
569 \\
\infty\end{array}$ & $\begin{array}{r}818 \\
684 \\
08\end{array}$ & 896 & 898 & $\begin{array}{l}892 \\
790\end{array}$ & 925 \\
\hline
\end{tabular}

"Cument dallars.

bAmulal production over 10,000 short tons each.

"Anntial production over 500,000 ahort tons aech.

${ }^{A}$ At mines that produced ower 10,000 short tons per year.

NA $=$ Not avallabte.

Nole: Totats mery not aqual the suln of components becense of independenk mounding.

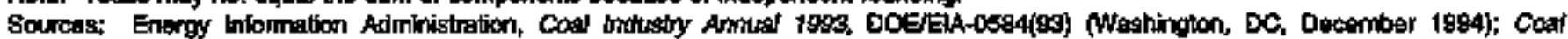

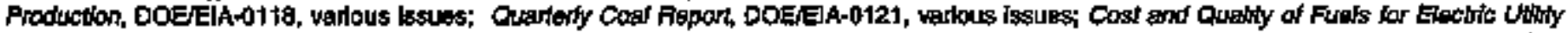

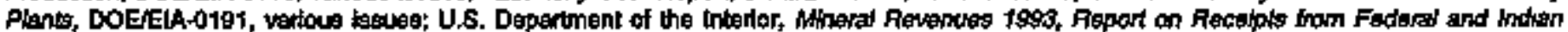

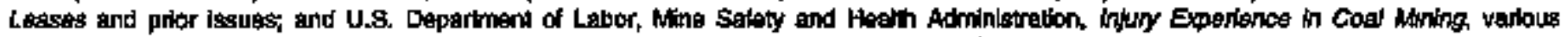

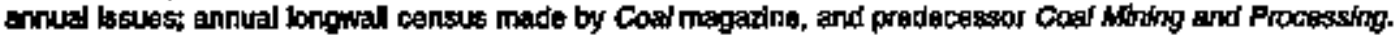


Figure 25. U.S. Coal Production by Rank, 1970-1993

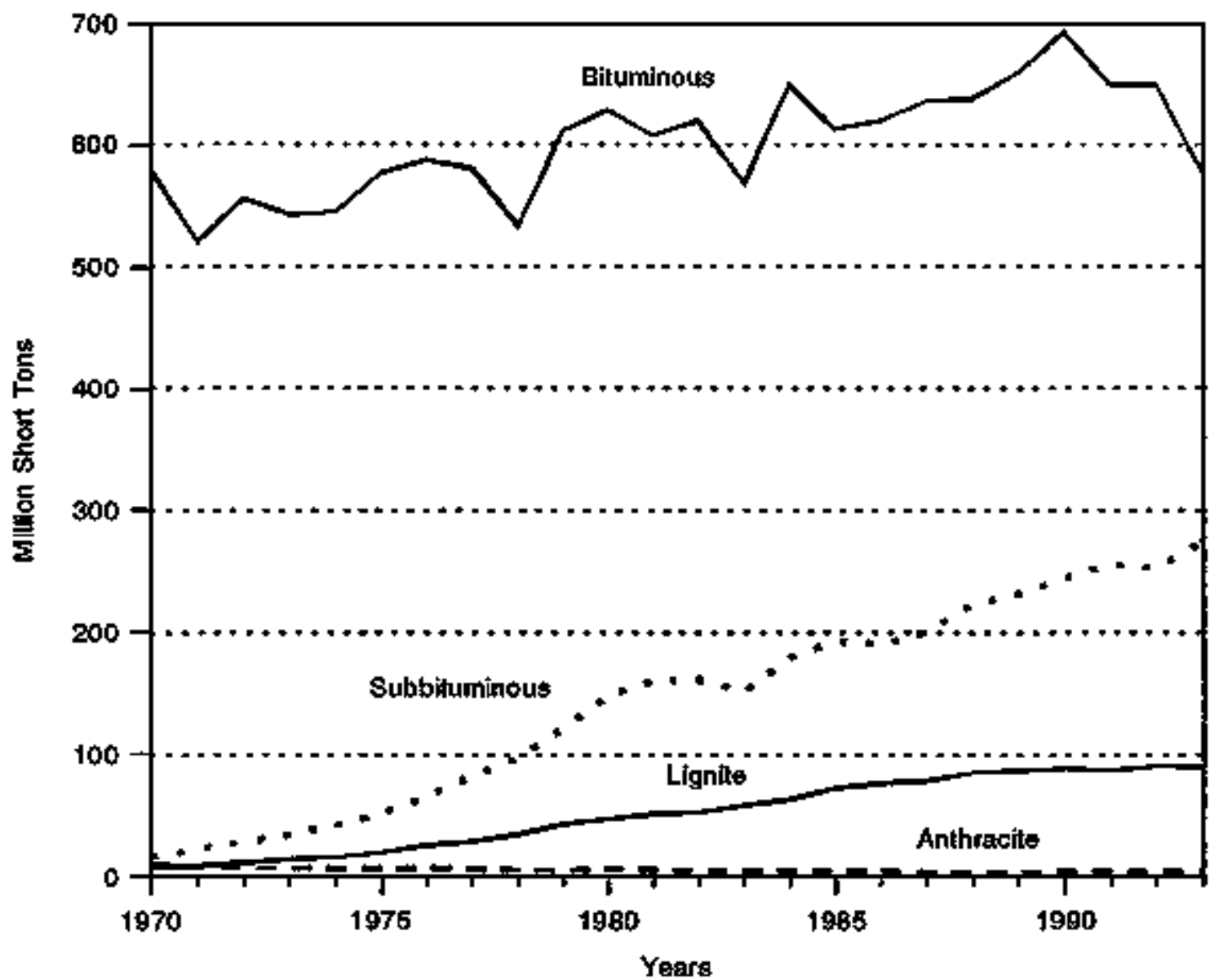

Gituninous coal is the major rank of coal mined in the United Stales, but lower-rank coals are becoming more tmportant while anthracile is dochining.

Source: Energy Information Adminastratson, Anntosl Energy Roviow 1998, DOE/EIA-0984(99) (Washington, DC, thly 1994); and Coal industry Annual 1993, DOEIEIA-0594(93) (Washinglon, DC, December 1994). 
Table 11. U.S. Coal Production by CoakProducling Region and state, Selected Years, 1970, 1980, 1990-1993 (Thousand Short Tons)

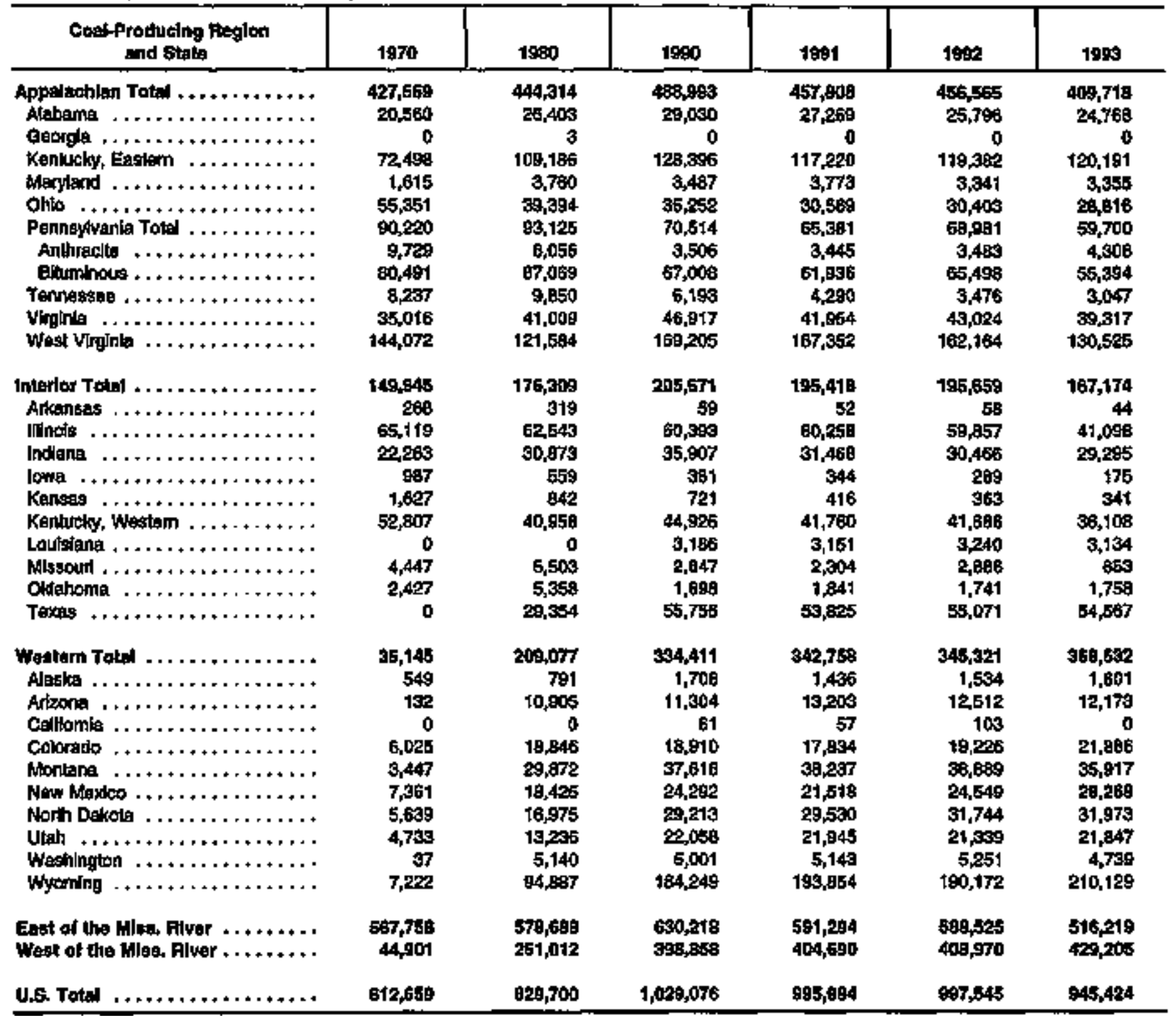

Note: Totels mey not equal sum of components because of Indeppendint rounding.

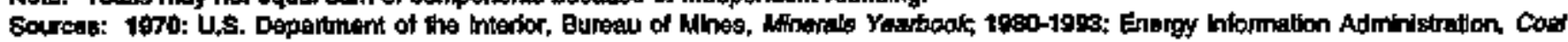

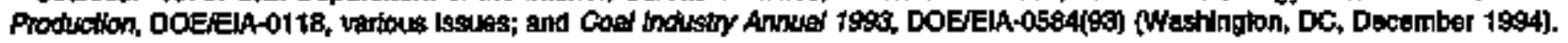


Table 12. Total U.S. Coal Production and Number of Wines by State and Type of Mining, 1993 (Thousand Short Tons)

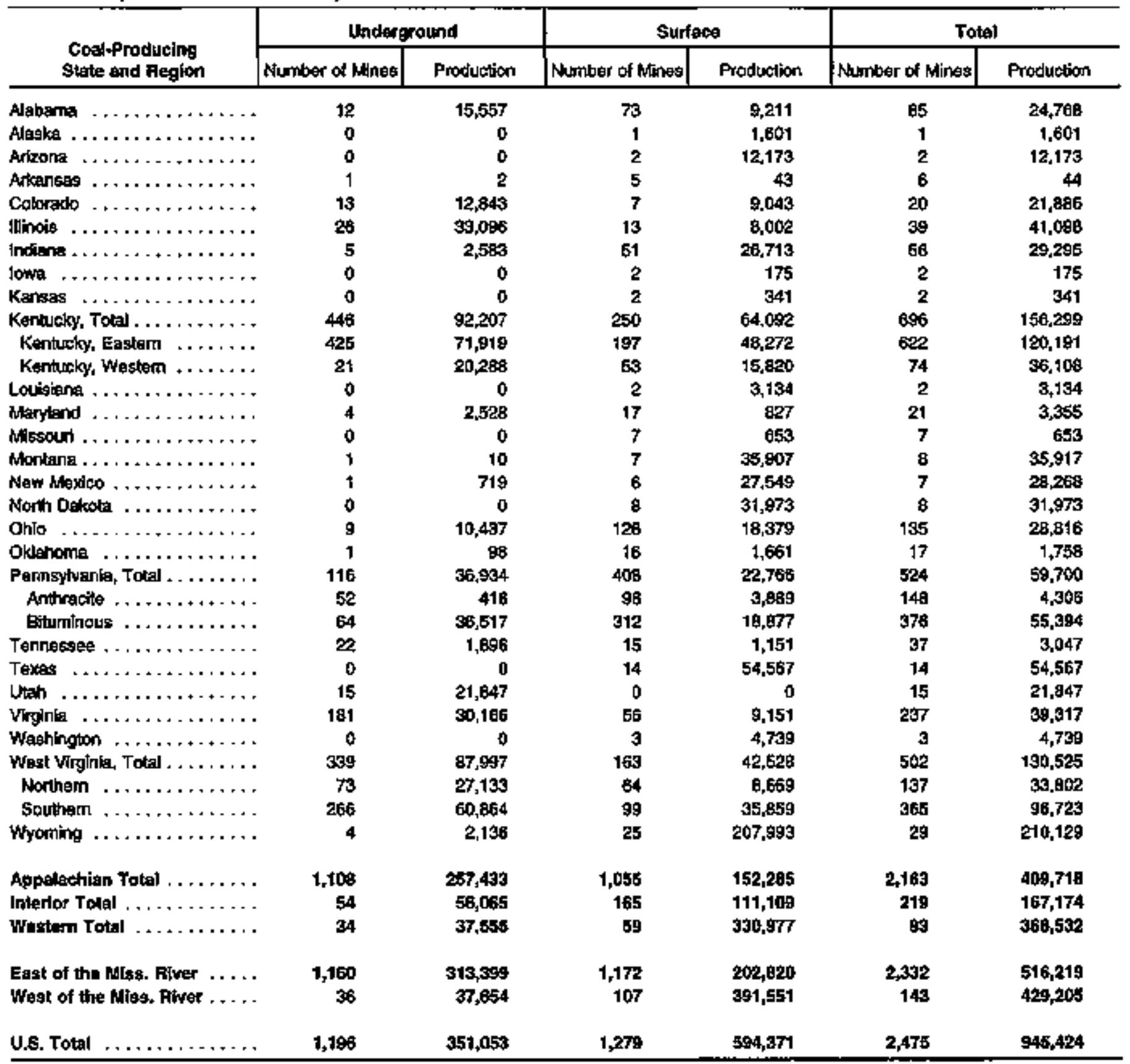

Note: Coel production exchudes silk, culm, reluse bank, slury dam, and dredge operations except for Permisyturania anthracilo. Tolalo may nol Eqüi sum of components becsuse of thdiependemt rounding.

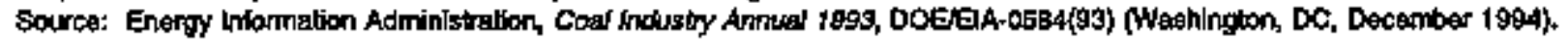


Flgure 26. U.S. Coal Production by Region and Type of Mining, 1970-1990

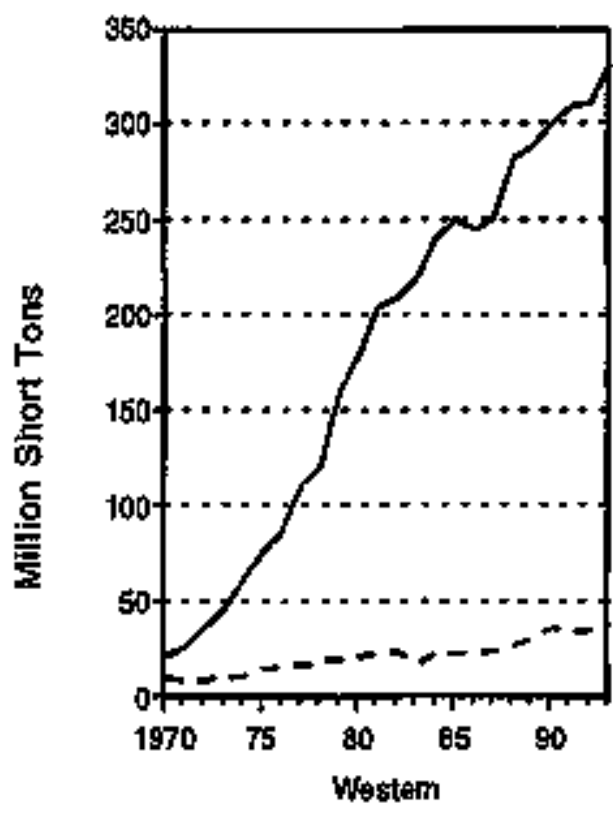

$\longrightarrow$
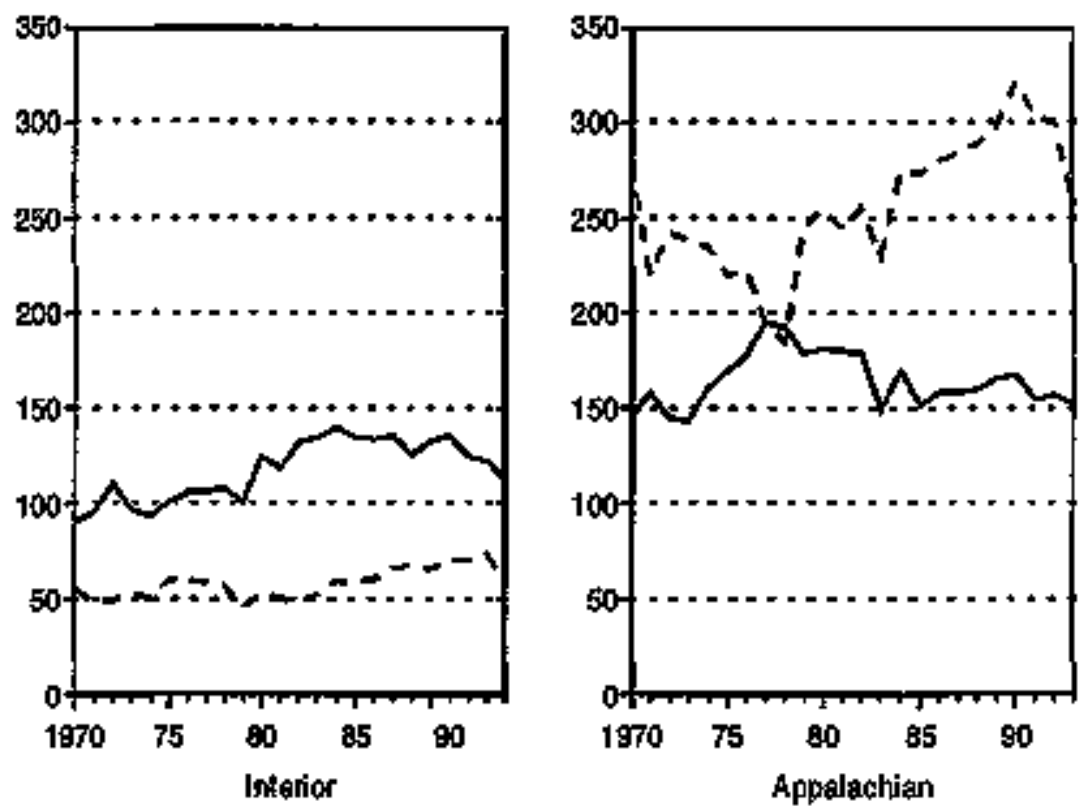

Surface-mined coal productlon in the West has increased markedly since 1970, largely bacause of a mapid sise in the coal output from the Powder River Basin in notheastent Wroming.

Soucce: 1970-1976: U.S. Department of the Interior, Bureau of Mlnes, Minerals Yeathook 1976 and forward: Energy Information Adrninistration, Coal Production, DOEJEIA-0116, valious issues; and Cogl industy Anncegl 1993, DOEJEIA-05B4(93) (Washington, DC, December 1994). 
Table 13. U.S. Underground Coal Production by Coal-Produeing Reglon, State, and Coalbed Thickneas, 1993 (Thousand Short Tons)

\begin{tabular}{|c|c|c|c|c|c|c|}
\hline $\begin{array}{c}\text { Cael-Productng Regton } \\
\text { ans gitati }\end{array}$ & $\begin{array}{l}\text { Leses then } \\
25 \text { Intinug }\end{array}$ & $\begin{array}{l}25-48 \\
\text { Inchos }\end{array}$ & $\begin{array}{l}49-72 \\
\text { hahes }\end{array}$ & $\begin{array}{l}\text { 7s-95 } \\
\text { Inehes }\end{array}$ & $\begin{array}{l}\text { More then } \\
95 \text { Inchas }\end{array}$ & $\begin{array}{c}\text { Totel } \\
\text { Production }\end{array}$ \\
\hline 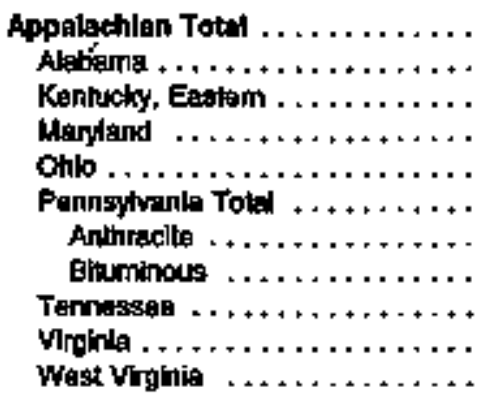 & $\begin{array}{r}915 \\
0 \\
808 \\
0 \\
0 \\
7 \\
0 \\
7 \\
0 \\
0 \\
101\end{array}$ & $\begin{array}{r}113,950 \\
3,055 \\
45,682 \\
14 \\
4,494 \\
9,422 \\
50 \\
9,371 \\
1,792 \\
17,759 \\
31,659\end{array}$ & $\begin{array}{r}105,360 \\
12,489 \\
21,045 \\
0 \\
5,943 \\
18,273 \\
138 \\
18,135 \\
64 \\
11,240 \\
37,298\end{array}$ & $\begin{array}{r}30,008 \\
0 \\
1,885 \\
2,500 \\
0 \\
8,886 \\
51 \\
8,896 \\
0 \\
1,091 \\
15,641\end{array}$ & $\begin{array}{r}5,385 \\
0 \\
2,085 \\
0 \\
0 \\
207 \\
41 \\
186 \\
0 \\
13 \\
0,229\end{array}$ & $\begin{array}{r}256,764 \\
15,544 \\
71,695 \\
2,514 \\
10,437 \\
36,795 \\
280 \\
36,515 \\
1,857 \\
30,096 \\
87,827\end{array}$ \\
\hline 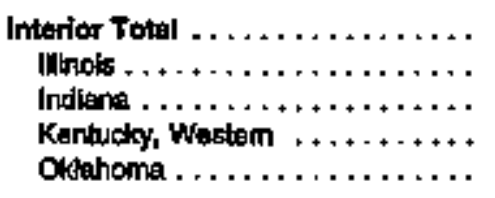 & $\begin{array}{l}0 \\
0 \\
0 \\
0 \\
0\end{array}$ & $\begin{array}{r}3,477 \\
0 \\
170 \\
3,209 \\
96\end{array}$ & $\begin{array}{r}31,898 \\
19,711 \\
1,108 \\
17,079 \\
0\end{array}$ & $\begin{array}{r}17,670 \\
16,368 \\
1,305 \\
0 \\
0\end{array}$ & $\begin{array}{r}3,019 \\
3,019 \\
0 \\
0 \\
0\end{array}$ & $\begin{array}{r}58,093 \\
39,096 \\
2,683 \\
20,299 \\
98\end{array}$ \\
\hline 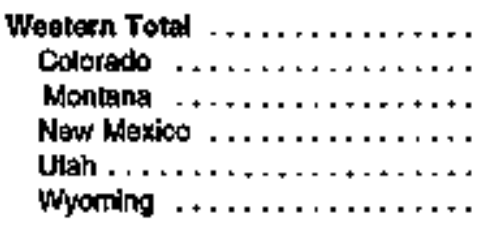 & $\begin{array}{l}0 \\
0 \\
0 \\
0 \\
0 \\
0\end{array}$ & $\begin{array}{r}359 \\
0 \\
0 \\
0 \\
163 \\
200\end{array}$ & $\begin{array}{r}410 \\
410 \\
0 \\
0 \\
0 \\
0\end{array}$ & $\begin{array}{r}8,846 \\
2,954 \\
10 \\
719 \\
5,169 \\
0\end{array}$ & $\begin{array}{r}27,939 \\
9,478 \\
0 \\
0 \\
16,525 \\
1,995\end{array}$ & $\begin{array}{r}37,549 \\
12,842 \\
10 \\
719 \\
21,841 \\
2,136\end{array}$ \\
\hline $\begin{array}{l}\text { East of the rise Rwer }, \ldots \ldots+\ldots \\
\text { Weat of the Miss. Rher } \ldots \ldots \ldots \ldots\end{array}$ & 915 & $\begin{array}{r}197,329 \\
491\end{array}$ & $\begin{array}{r}138,248 \\
410\end{array}$ & $\begin{array}{r}47,679 \\
6,1046\end{array}$ & $\begin{array}{r}\text { B,553 } \\
27,998\end{array}$ & $\begin{array}{r}312,720 \\
37,645\end{array}$ \\
\hline U.s. Total $\ldots \ldots \ldots \ldots \ldots \ldots \ldots$ & 915 & 117,780 & 138,658 & 86,519 & 36,492 & 350,365 \\
\hline
\end{tabular}

Notes: Daka for bed thicknose and production are given as reportad on Form ElA-7A and do not necesserly represemi complete coweraga; they exclude mines thest produced loss than 10,000 ehot tons. Totel may not equel stm of componenis becauso of independent rounding. Source: Endrgy Information Adrninkstration, Form EAA-7A, "Cod Production Reporl." 
Table 14. U.S. Surface Coal Production by CoalProducing Reglon, State, and Coalbed Thieknese, 1993 (Thousand Short Tons)

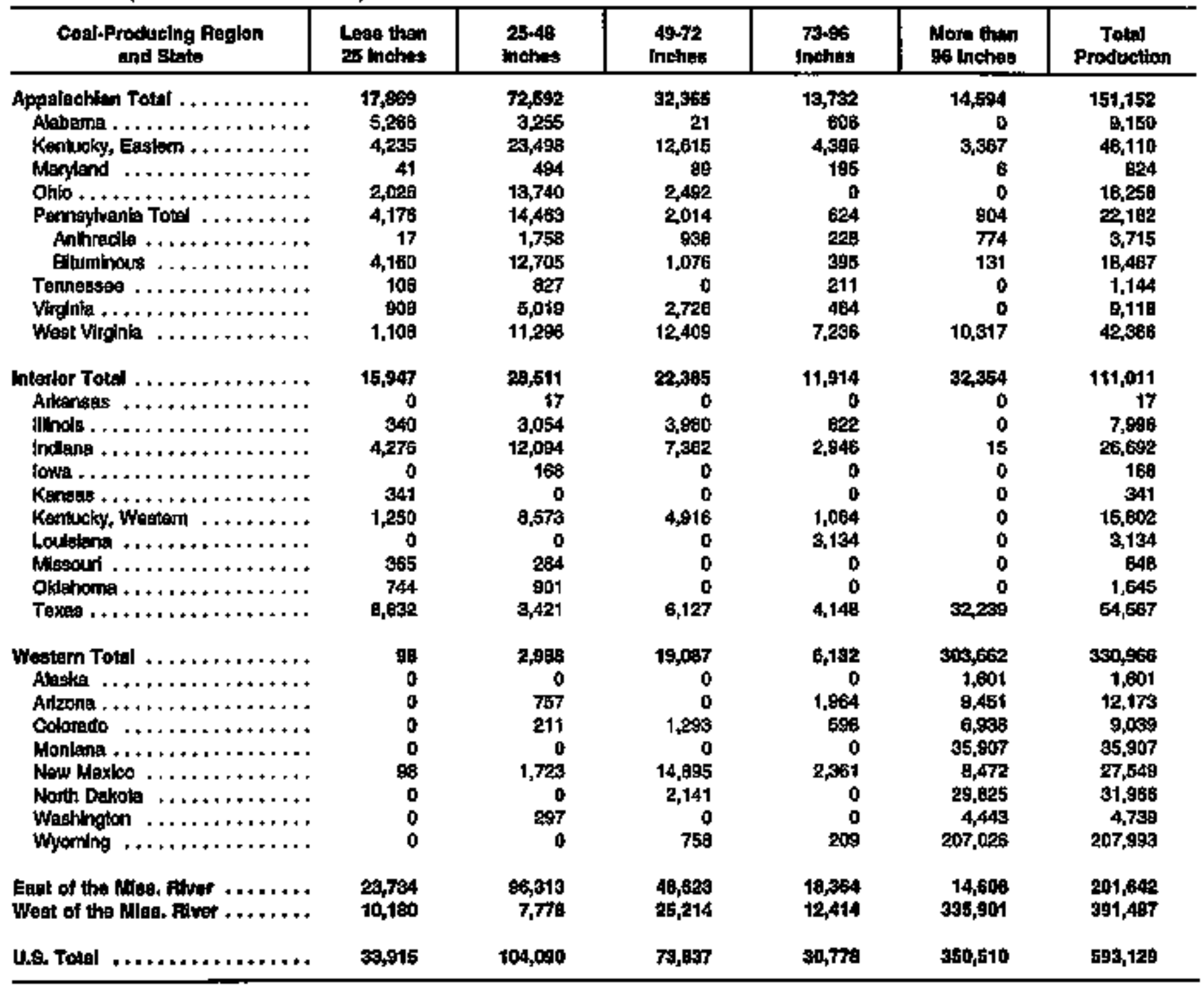

Noteat Data for bed thlokthess and production are given es reportod on Form ElA-7A and do not necesserily represent cornplele coverage;

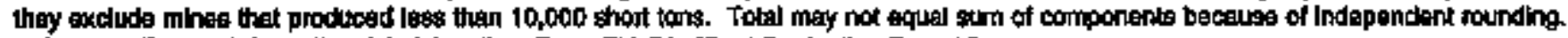
source: Energy Information Adminiabration, Form ElA-7A, "Coal Production Fieporl," 
Table 15. U.S. Coal Production by Coal-Producing Reglon, State, and Coalbed Thickness, 1993 (Thousand Short Toxis)

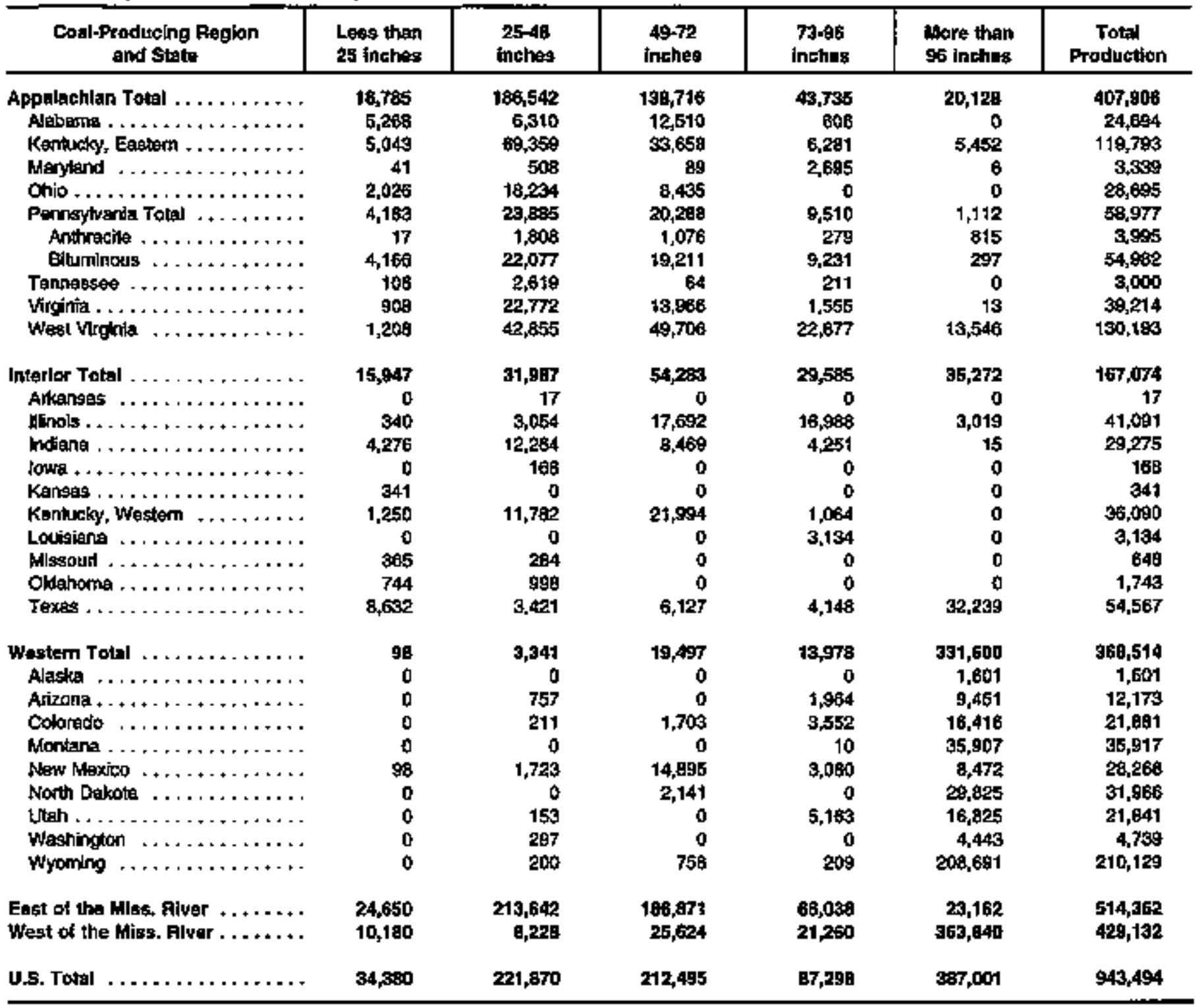

Noles: Date for bed thtckness and production arg given as reported on Font ElA-7A and do not necessaily represent complete coverager biey exclude mines that produced less than 10,000 short kons. Total moy not equel sum of components becausp of trutapendant rounding. Source: Enargy Information Adrinistrebion, Form ElA-7A, "Cod Production Report." 
Table 16. Production (Sales Volume) from Federal and Indian Coal Lands Compared with Production from Other Sources and Coal Royalites, Selected Years, 1970, 1975, 1980-1993

\begin{tabular}{|c|c|c|c|c|c|c|c|c|c|}
\hline \multirow{2}{*}{\multicolumn{2}{|c|}{ Year }} & \multicolumn{3}{|c|}{ 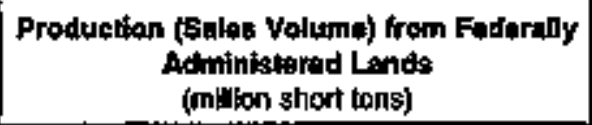 } & \multirow{2}{*}{$\begin{array}{l}\text { Production } \\
\text { from other } \\
\text { Sources } \\
\text { (m[lion short } \\
\text { tons) }\end{array}$} & \multirow{2}{*}{$\begin{array}{l}\text { Total U.S. } \\
\text { (mirion sthort } \\
\text { tons) }\end{array}$} & \multicolumn{3}{|c|}{$\begin{array}{l}\text { Coal Royalties" } \\
\text { (million dollars) }\end{array}$} \\
\hline & & Federa & Indlan & Total & & & Fecleral & Inditan & Told \\
\hline 1970 & $+\ldots \ldots$ & 7.4 & 4.9 & 12.0 & 600.6 & 6127 & 1.1 & 0.7 & 1.8 \\
\hline 1975 & $\ldots \ldots \ldots$ & 26.9 & 18.7 & 43.6 & 611.1 & 654.6 & 4.9 & 3.5 & 8.3 \\
\hline 1990 & $\ldots+\ldots$ & 69.1 & 20.8 & 92.9 & 736.8 & 829.7 & 实. & 7.8 & 40.1 \\
\hline 1981 & $\ldots \ldots \ldots$ & 116.5 & 22.3 & $13 B .8$ & tag.0 & 823.8 & 490 & 0.6 & 51,6 \\
\hline 1992 & $\ldots \ldots$ & 101.1 & 28.9 & $1 \% 0.0$ & 708.1 & 838.1 & 61.9 & B.5 & 70.4 \\
\hline 1983 & $\ldots+\ldots+\cdots$ & 99.7 & 25.6 & 124.3 & 657,8 & 7821 & 52.3 & 9.4 & 61.7 \\
\hline 1984 & $\ldots \ldots \ldots$ & 115.8 & 20.5 & 136.3 & 759.6 & gg5.9 & 69.4 & 7.6 & 77.0 \\
\hline 1985 & $+\ldots+\ldots$ & 159.2 & 25,4 & 184,6 & 699.0 & 883.6 & 100.5 & 23.4 & 126.9 \\
\hline 1886 & $\ldots \ldots \ldots$ & 168.7 & 20.9 & 189.7 & 700.6 & g90.3 & 108.4 & 28.5 & 137.9 \\
\hline$\uparrow 987$ & $\ldots \ldots$ & 171.2 & 24,0 & 195.2 & 723.6 & 918.8 & t\$2.5 & 90.5 & 180.0 \\
\hline 1988 & $\ldots \ldots \ldots$ & 1002 & 26.2 & 2025.4 & 724.8 & 950.3 & 1728 & 46.7 & 218.5 \\
\hline 1989 & $\ldots \ldots \ldots+$ & 209.3 & 27,0 & 236.3 & 744.5 & 980.7 & 194.5 & 47.7 & 242.2 \\
\hline 1900 & $\ldots \ldots \ldots$ & 245.4 & 27.5 & 273.4 & 755.7 & $1,029.1$ & 235.1 & 50.8 & 296.9 \\
\hline 1991 & $\ldots+\ldots+$ & 240.4 & 27,4 & 267.8 & 728.2 & 996.0 & 276.7 & 52.9 & 399.6 \\
\hline 1992 & $\ldots \ldots \ldots$ & 238.5 & 28.1 & 266.6 & $7 \$ 0.9$ & 9g7.5 & 259.6 & 55.9 & 325.4 \\
\hline 1993 & $\ldots \ldots$ & 267.6 & 28.1 & 205.7 & 659.7 & 945.4 & 2642 & 84.9 & 329.0 \\
\hline
\end{tabular}

Cumeont dopliars;

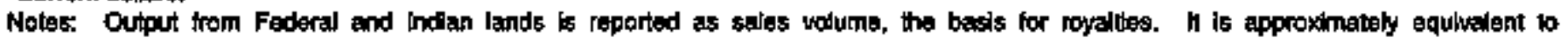

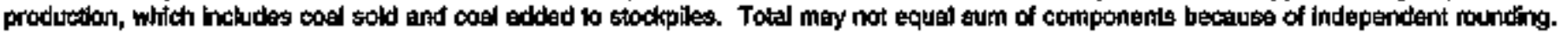

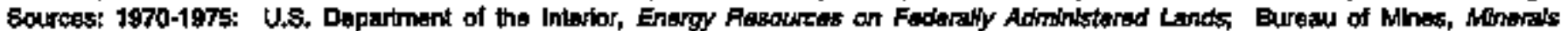

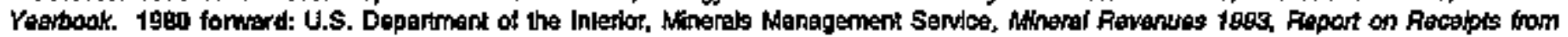

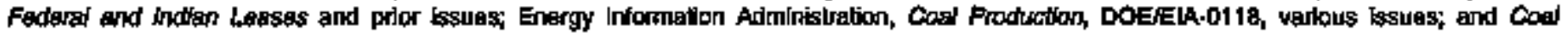
Indusiry AnnLal 1998, DOEJEIA-0584(93) WWashinglon, DC, Decamber 1994). 
Table 17. U.S. Coal Mining Acreage, Production (Seles Volume) and Royaltios from Foderal and Indian Leases by State, 1993

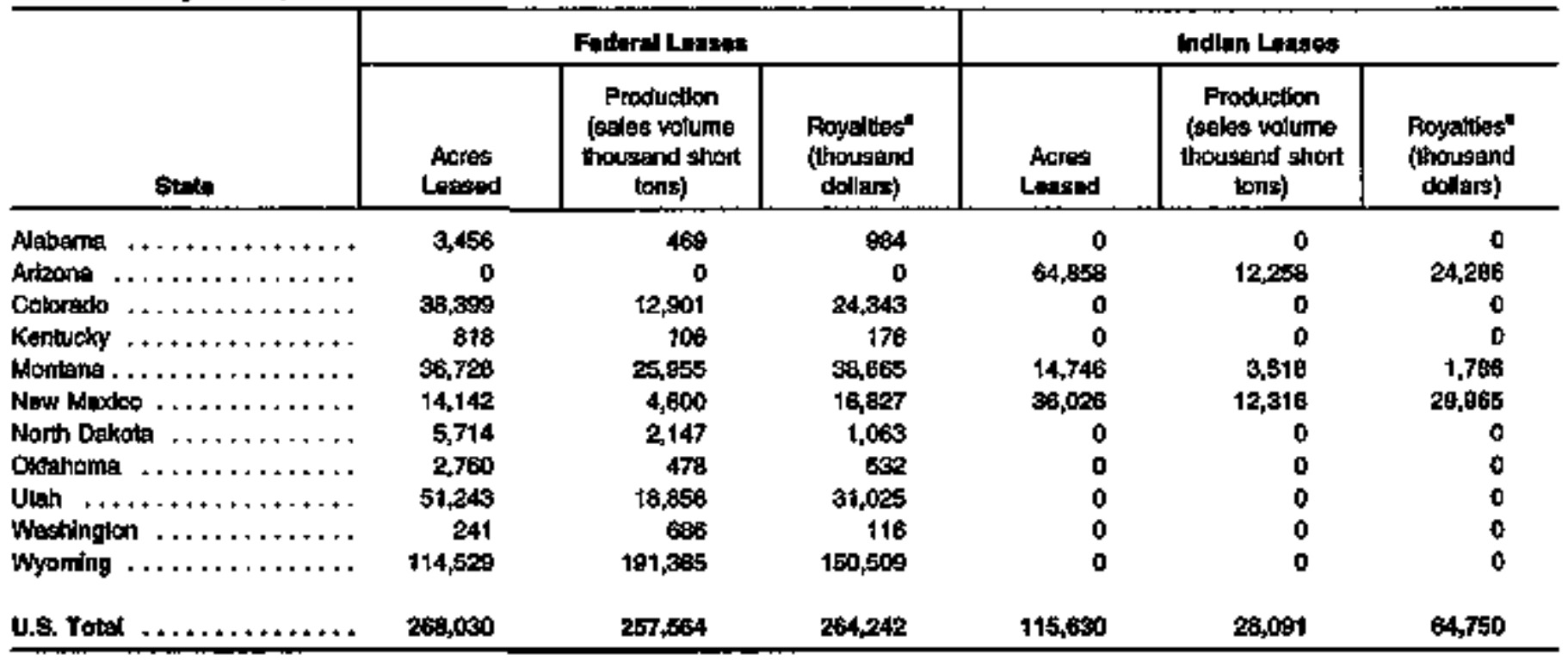

"Current dollars.

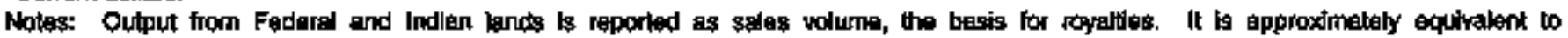

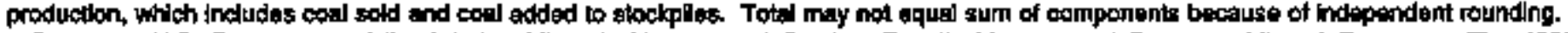

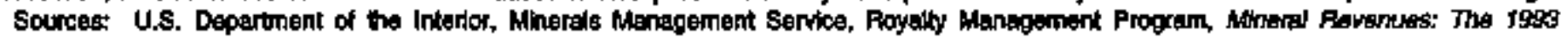

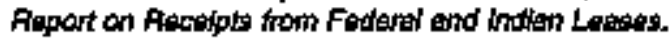


Table 18. U.S. Production Trends in Bituminous Coal and Lignite, 1900-1993

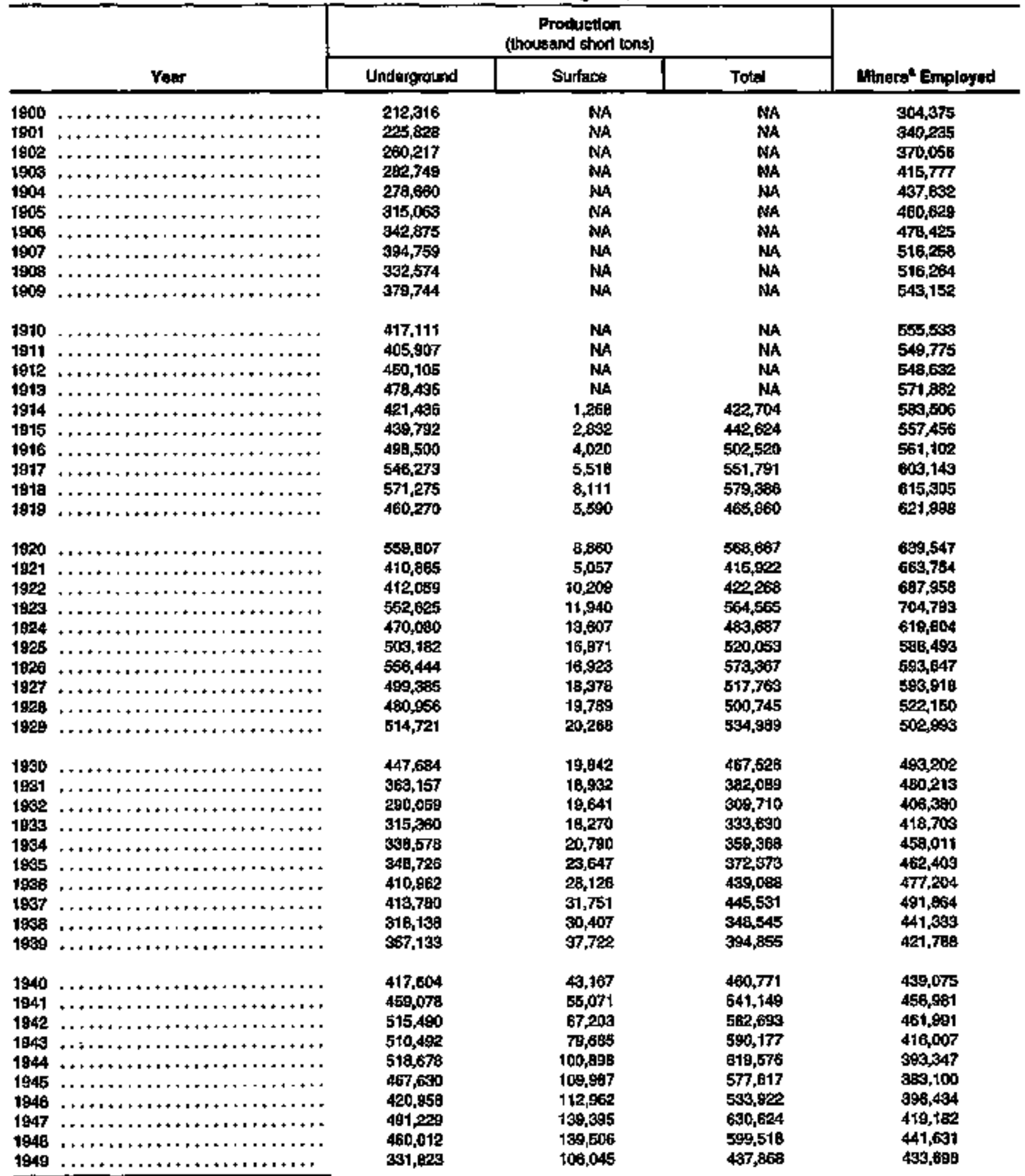

Sea looinotes at end of table 
Table 18. U.S. Production Trends In Bituminous Coal and Llgnite, 1900-1999 (Continued)

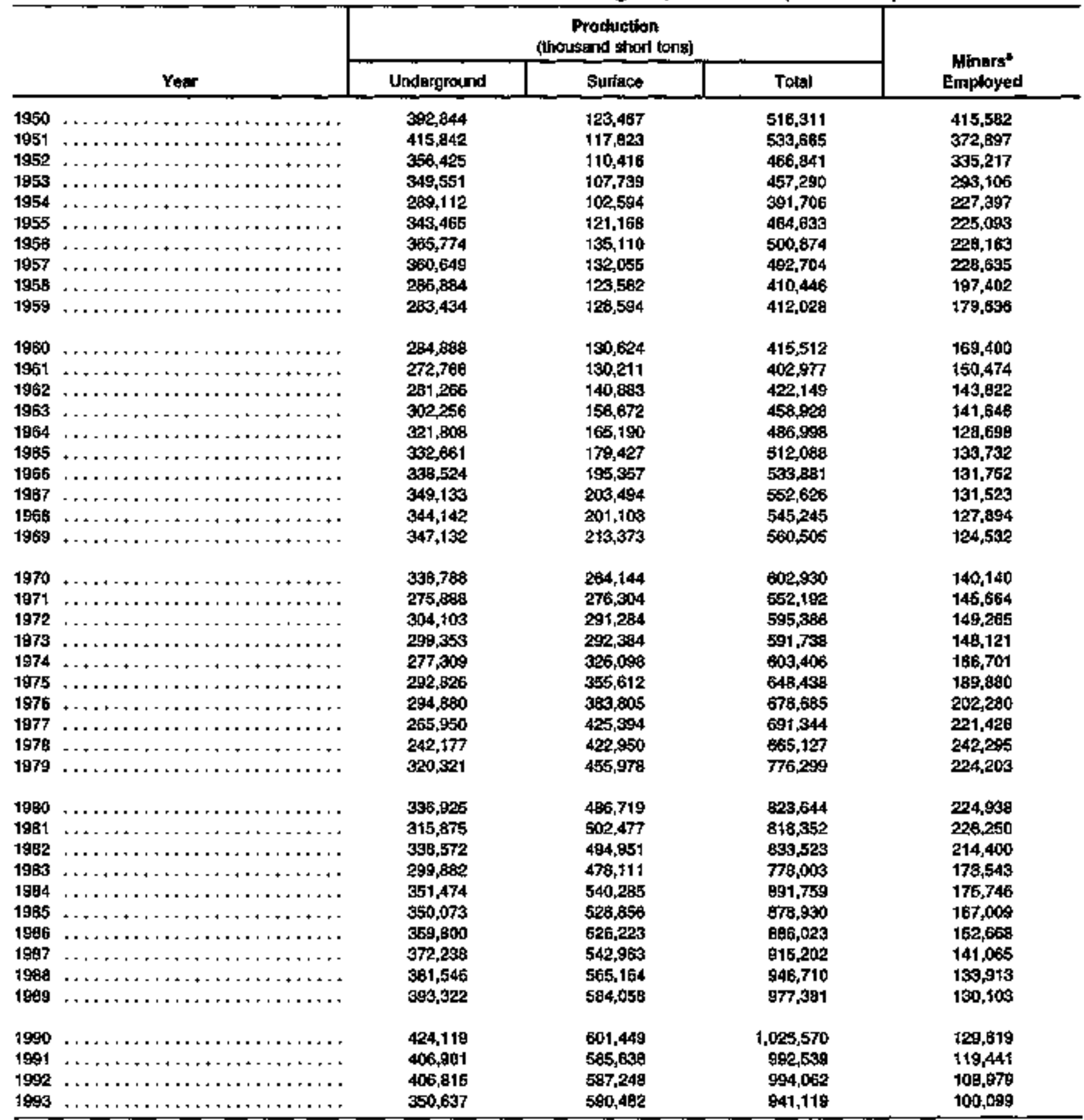

AAfier 1978, excelukdes miners eniployed at mines that procluced lass than 10,000 tons.

NA $=$ Not evallable; rekatively amell amounis included with underground.

Note: Subbituminous coel is included with bituritous coal. Totals may not equal sum of components because of indepandent rouncting.

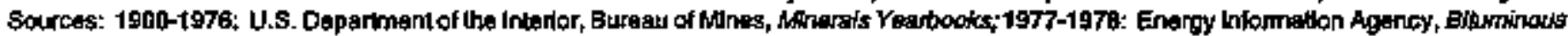

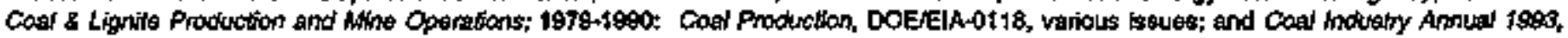
DOE EIA-0584(93) (Washington, DC, Detember 1994). 
Table 19. Production Trends in Pennsyivania Anthracite, 1900-1993

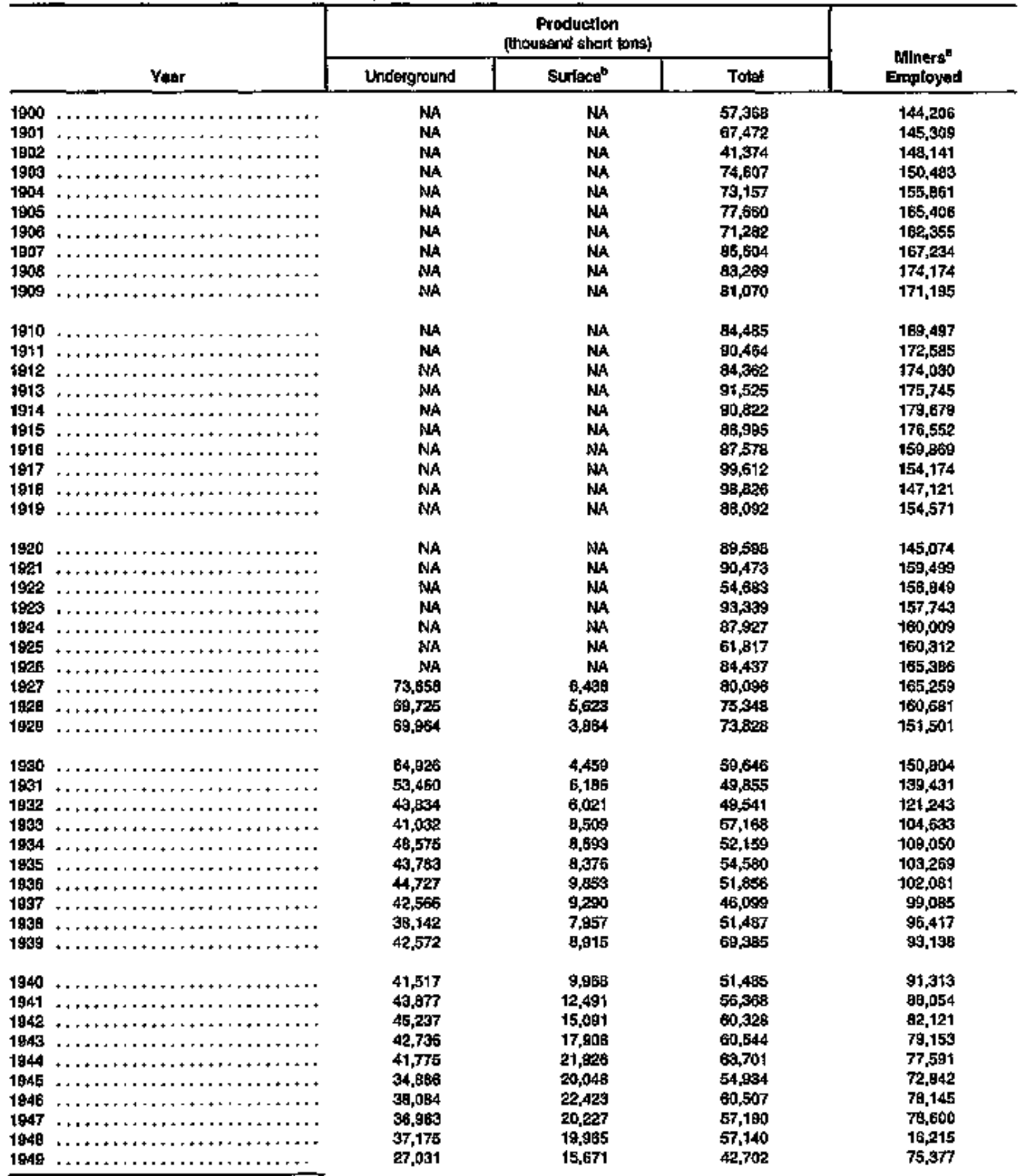

Ses boinotes at and of toble. 
Table 19. Production Trends in Pennsylvanla Anthracite, 1900-1993 (Continued)

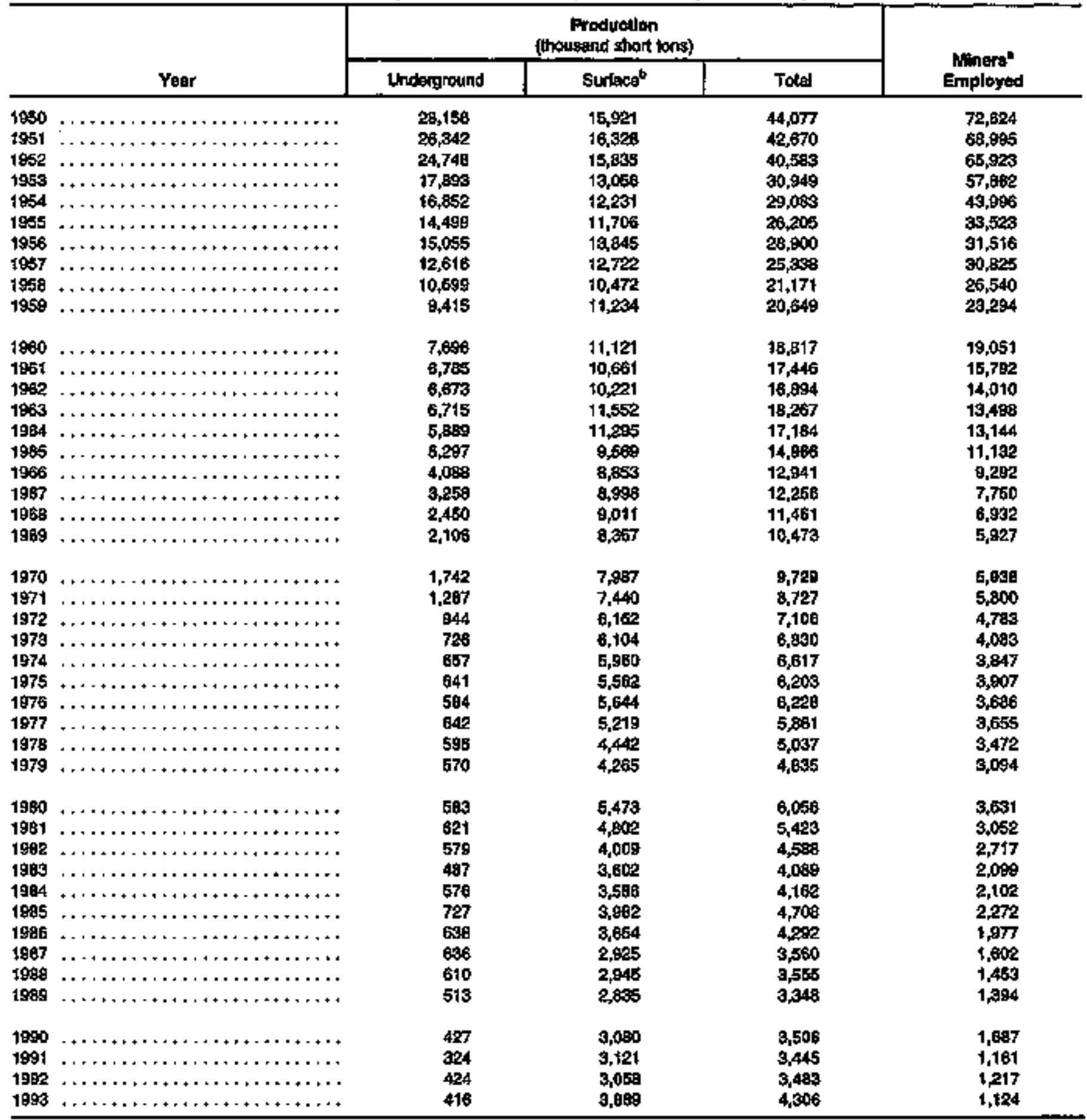

Alter 1978, exciludes minere employed at mines that produced lees than 10,000 sons.

"Surface producton indudes culm bank and river drodging operations.

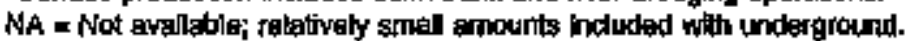

Note: Totals may not equal sum of companents because of Independent nounding.

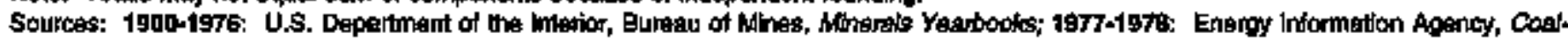

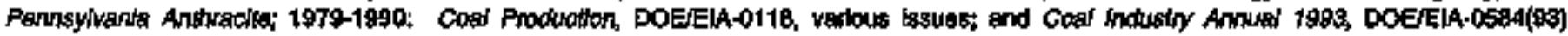
(Washington, DC, December 1994). 
Table 20. U.S. Labor Productivity in Coal Wining, 1949-1993 (Avaraga Short Tons par Minar per Hour)

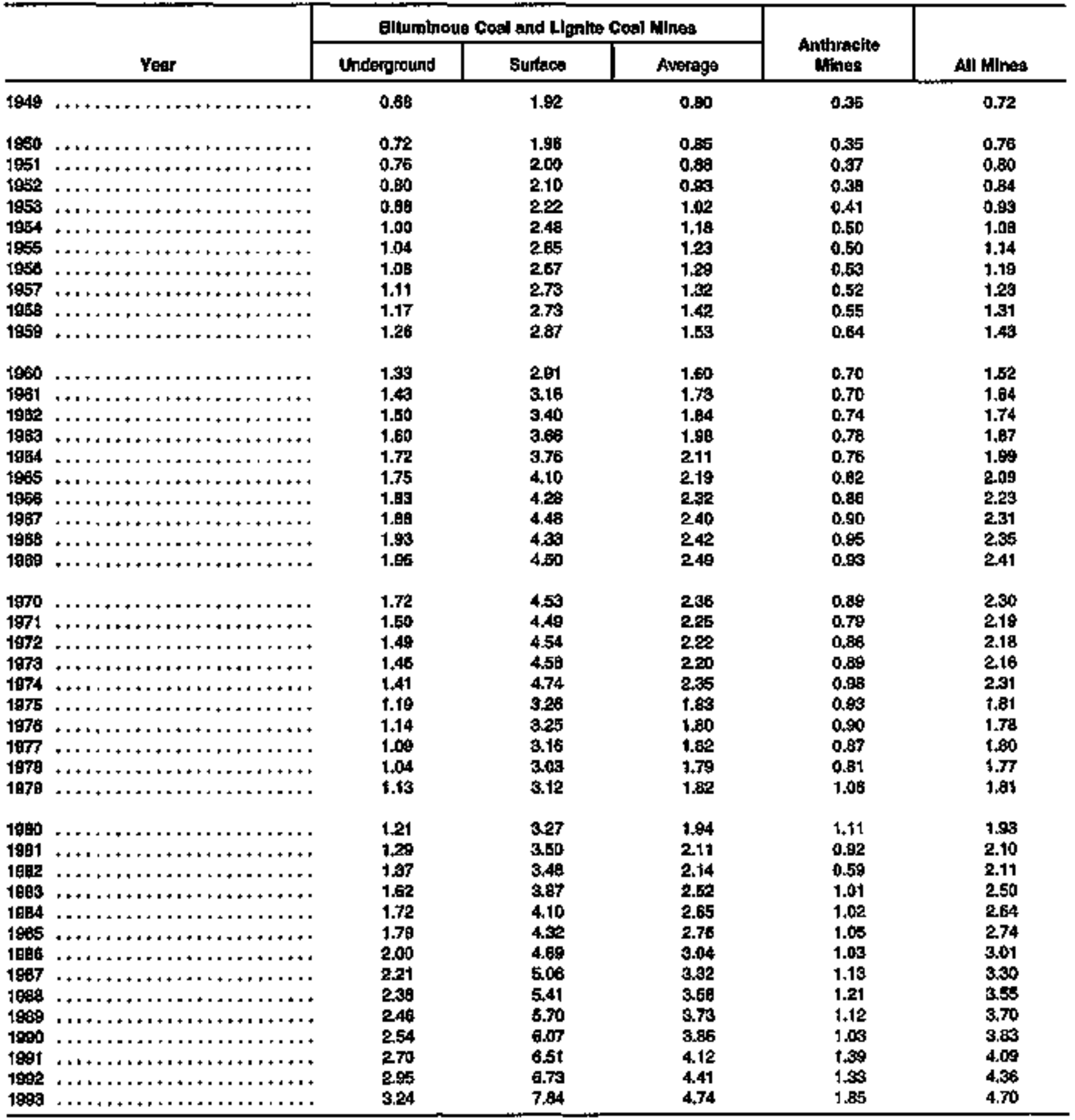

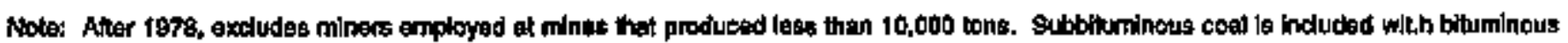
coel. Totala may not equal sum of components beceruse of indepandert rounding.

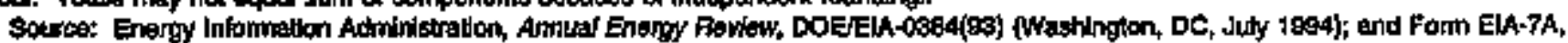
"Coal Produotion Repot." 
Table 21. Profile of U.S. Coal Miners, 1986

\begin{tabular}{|c|c|}
\hline Employmant Catogory & $\begin{array}{l}\text { Worker } \\
\text { statistice* }\end{array}$ \\
\hline Ags (mean) $\ldots \ldots \ldots \ldots \ldots \ldots$ & 39 \\
\hline Idele (percemt) $\ldots \ldots \ldots \ldots \ldots \ldots$ & 9B \\
\hline \multicolumn{2}{|l|}{ Eatuctionet (percent) } \\
\hline High school Dlplonk $\ldots+\ldots \ldots$ & $\$ 4$ \\
\hline Vocational Schowl Diploma . . . . . . . & 8 \\
\hline Some College . . . . . . . . . . & 10 \\
\hline Colloge diagres $\ldots \ldots+\ldots \ldots \ldots++$ & 5 \\
\hline \multicolumn{2}{|l|}{ Werk experience (medten, yeara); } \\
\hline At present job $\ldots \ldots \ldots \ldots \ldots$ & 4 \\
\hline At prosent company $\ldots \ldots \ldots \ldots$ & 8 \\
\hline Totel mining . . . . . . . . . . . & 11 \\
\hline $\begin{array}{l}\text { Job-rilated training duing the } \\
\text { last two years (median, heurs) ... }\end{array}$ & 35 \\
\hline
\end{tabular}

"Production workers.

Source: U.S. Department of the Interlor, Bureau of Wines, Intormation Clrculer 9182, "Cherecterization of the 1986 coal Miring Warkforce" (1988).

Table 22. U.S. Coal Mining Average Employment, Hours Worked, and Earnings, Selected Years, 1980, 1985, 1990-1993

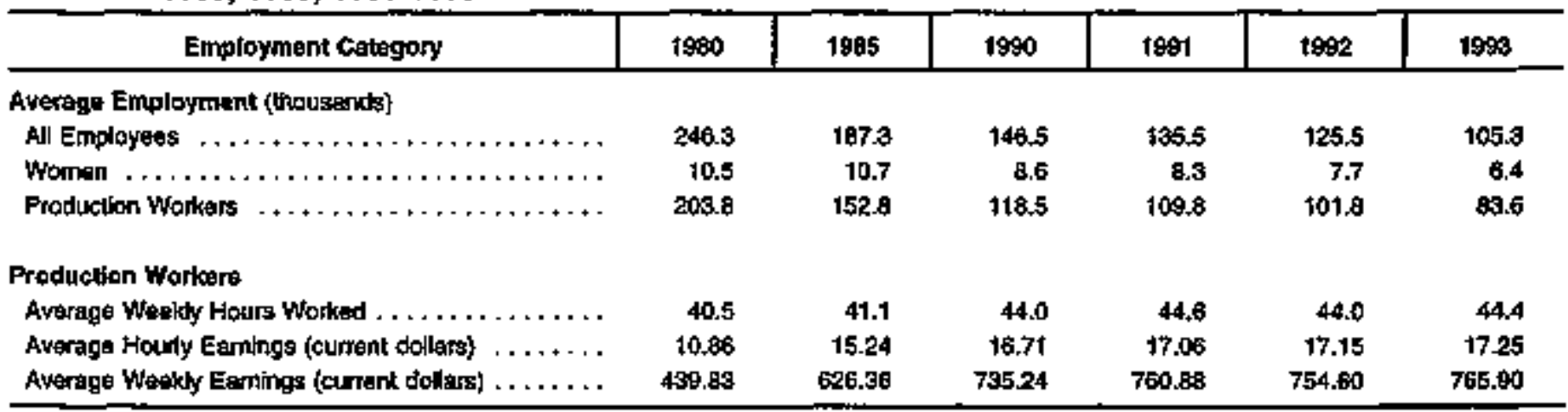

Note: Employment data differ trom those collected by the Energy Intormation Administrallon due lo ditleverd survey criterla.

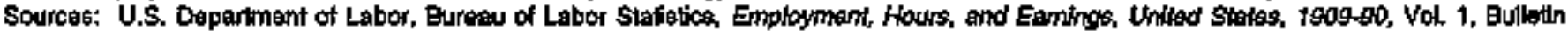
2370 (Washington, DC. Harch 1991), ard Employment, Hows, and Eamings, Unitsd States, 1981-93, Btilletin 2429 (Wasbington, DC, Augusl 1993); 1993: U.S. Deparumem of Lebor, Bureau of Labor Stalistics, Dede Users and Publicafion Senvices Group. 
Figure 27. U.S. Coal Mining Fatalitles, 1900-1993

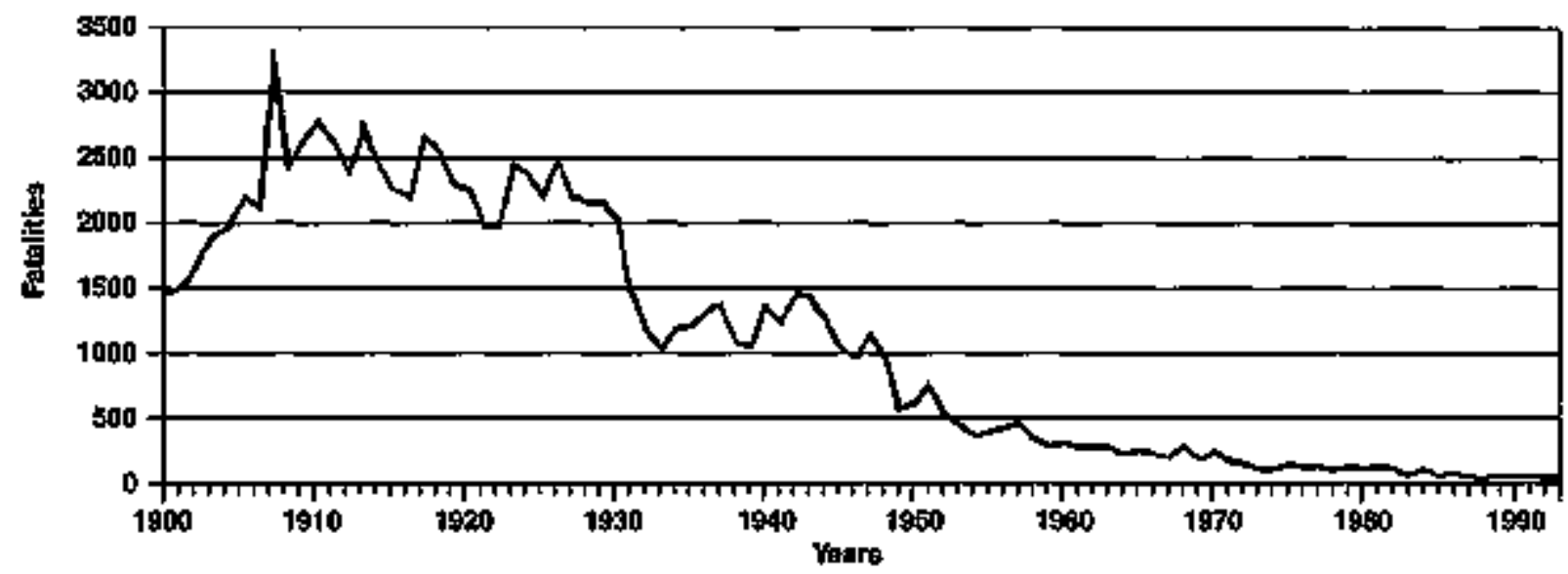

Although stll dangernus, casl mining has become safer dive to mechanizatian, roof boling, and stingent safery ragulations. in 1907, U.S. coal mining chalmad a racort 3,242 Wves.

Source: U.S. Department of Labor, Mine Sefoty and Heallh Administration, Denver Safety and Healih Technology Center.

Table 23. U.S. Coal Mine Injuries, Selected Years, 1975, 4980, 1985, 1990-1999

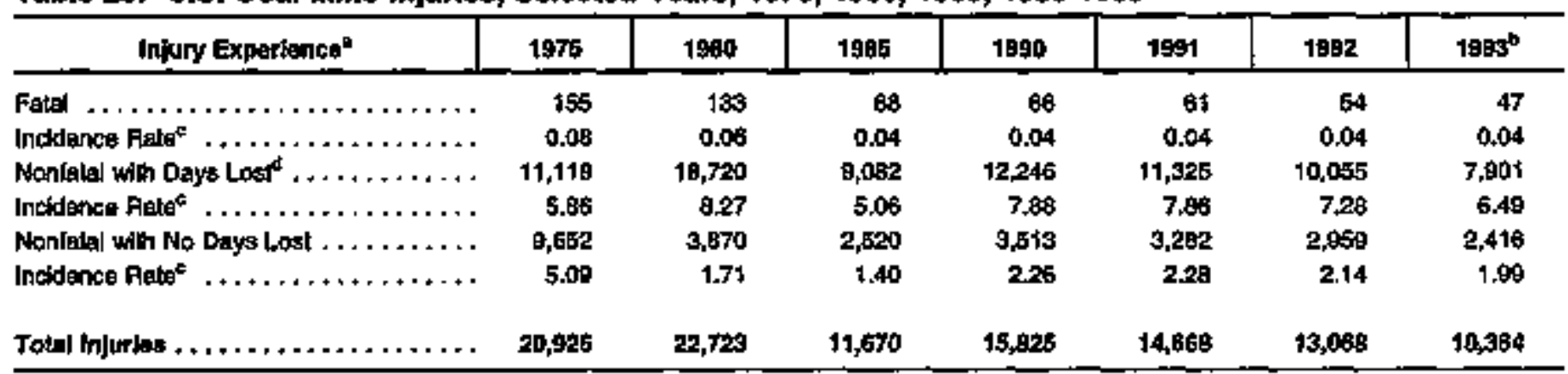

Includes cifice wakers and contractors.

breliminary.

"Nhmbers of In;uries par 200,000 amplopreethotrs.

includes infulies thax reeuth in rasiricted work activity.

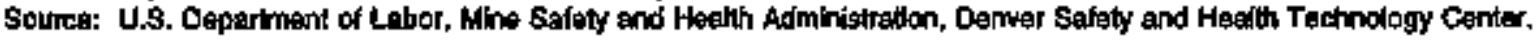


Figure 28. Coal Distribution from the Three-Leading Coal-Producing States, 1993 (Million Short Jons)
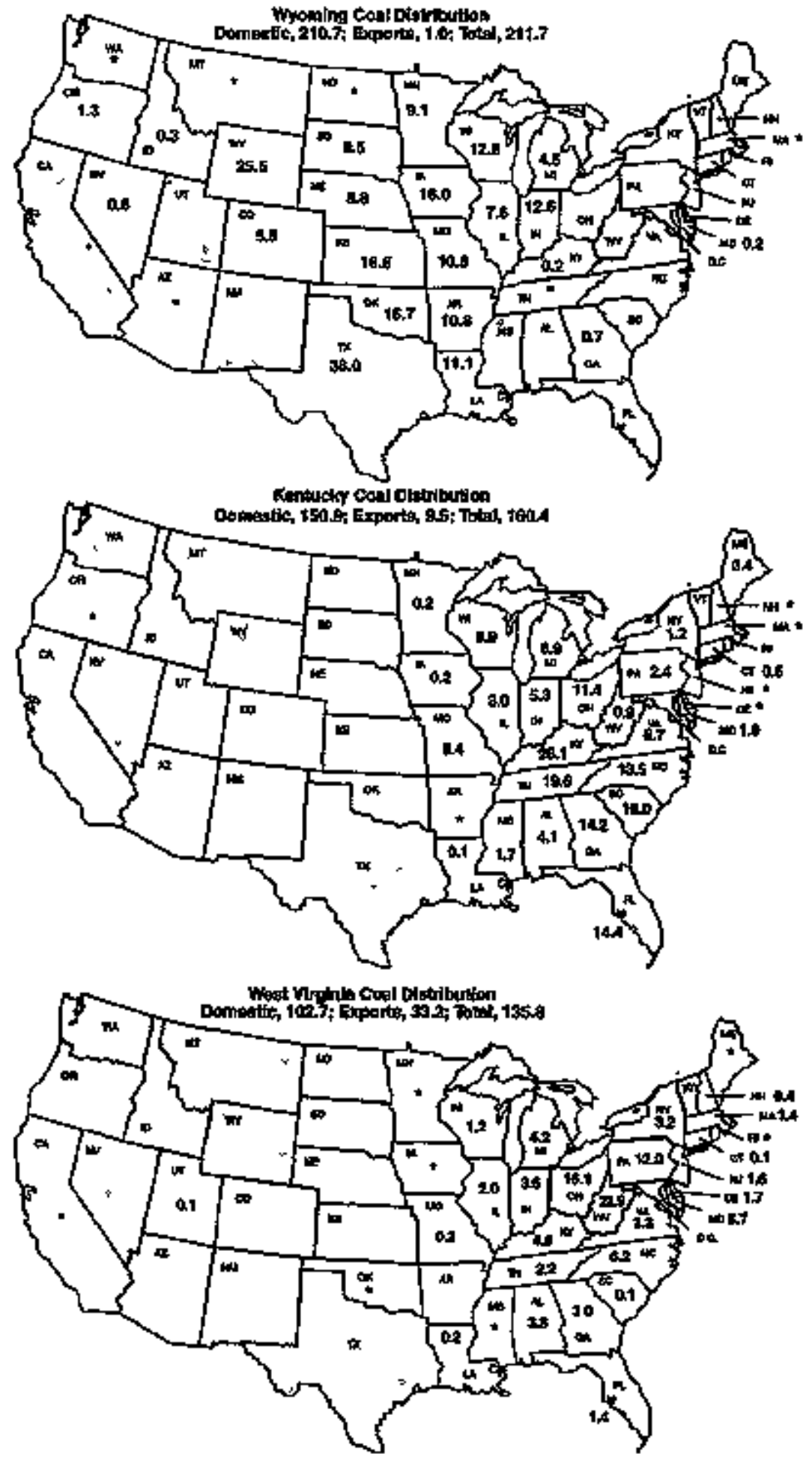

Amount is then 0.1 millian short tons.

Source: Energy Informelion Adninistration, Cosi industry Annual 1998, DOEE(A-0584(99) (Washington, DC, Decenber 1994). 
Figure 29. U.S. Coal Production: End Use Distribution by Supplying Area, 1998 (Million Short Tons)

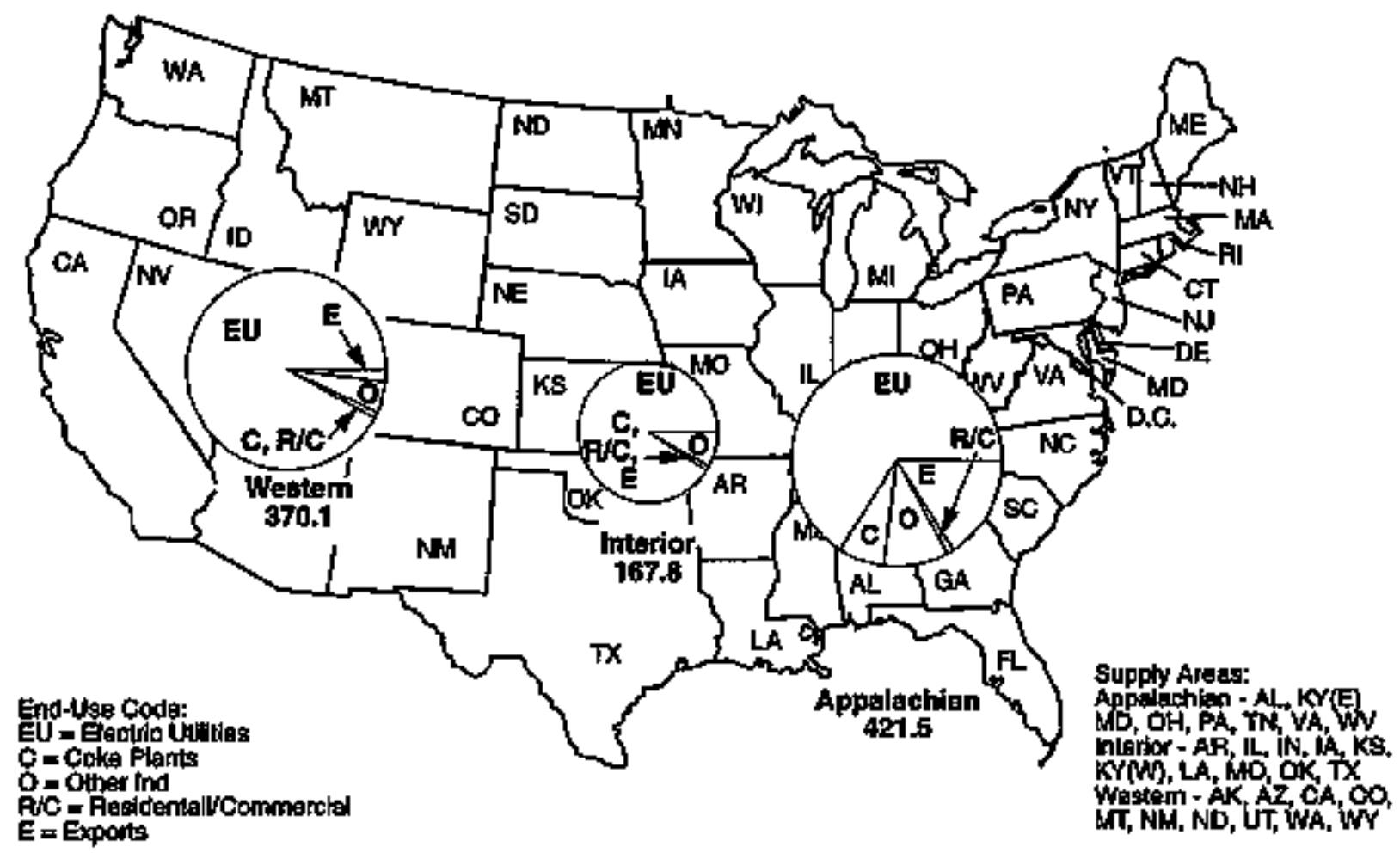

Abouk 80 percent of the cod mined in the Unitad States is sent to electric power plants.

Source: Energy Information Administration, Coal industry Anmul 1993, DOEEIA.0584(93) (Washington, DC, December 1994). 
Figure 30. Coal Shipments for U.S. Consumption by Supplying Areas and by Transportation Hethoda, 1998

(Millition Short Tons)

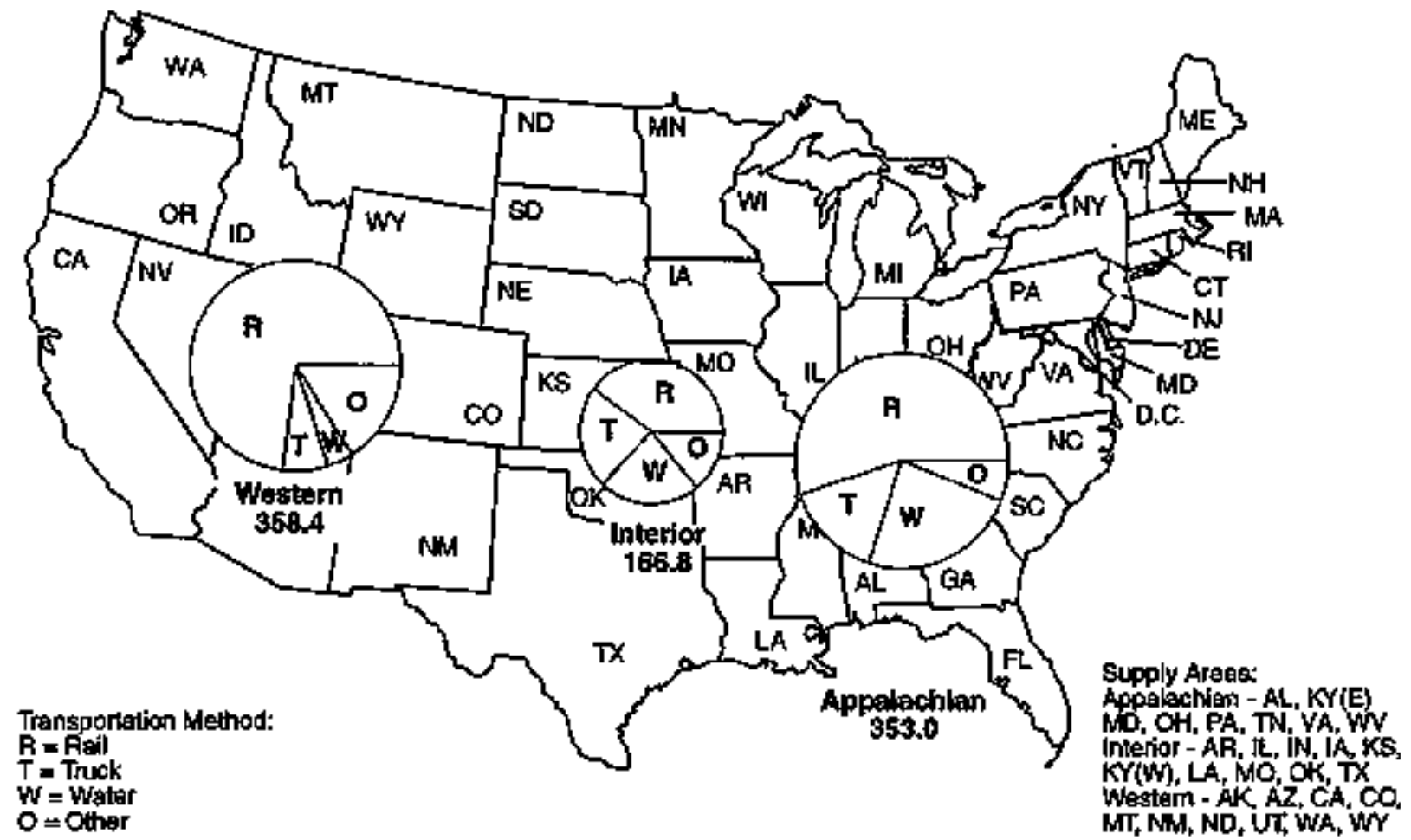

"Olher" inchudes tramwaycomveyor, turry plpeline (in Westerm), and wiknown or not revealable melhods.

Railroads are the foundation of the U.S. coal transportation system.

Source: Energy tniomation Administration, Form ElA-6, "Coal Disiribution Report" 
Table 24. U.S. Coal Supply and Dlsposition, 1949-1993 (Million Short Tons)

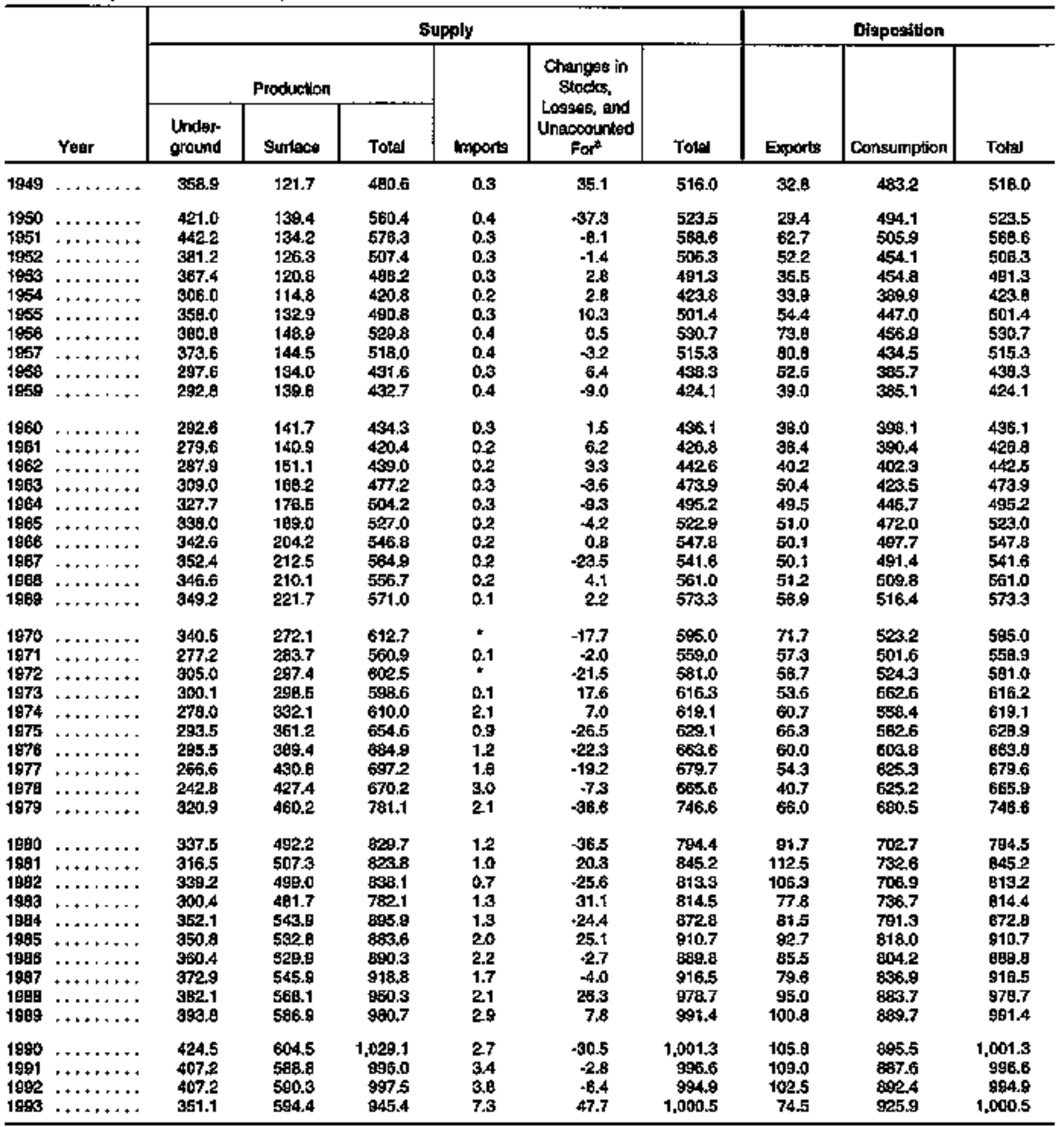

Belanching liem batween supply and dispostiton.

"Less than 0.05 million short ions.

Note: Totels may not equat sam of components beceuse of independent rounding.

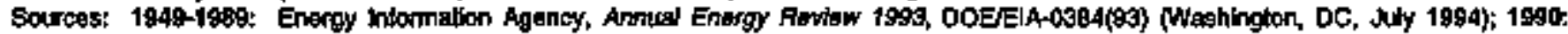

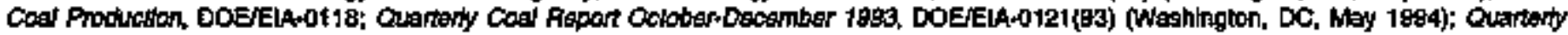

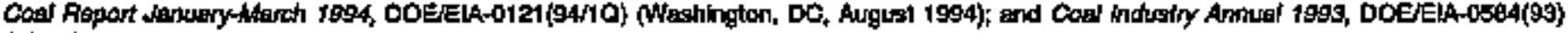
(Washington, DC, December 1994). 
Figure 37. U.S. Coal Supply and Disposition Pattems, 1993

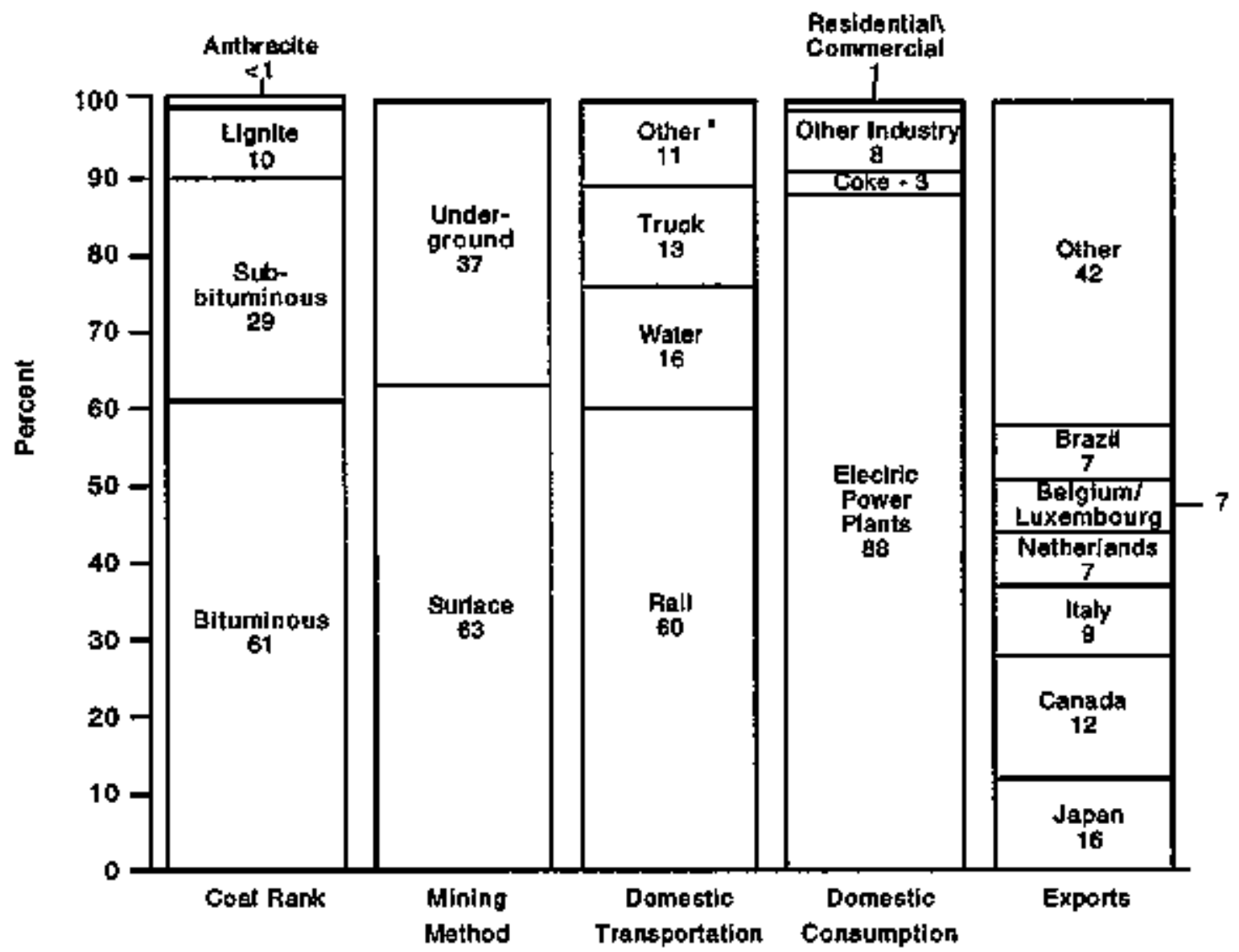

"Tramway/Conveyor, slumy pipeline, and untanown or not revealable methods.

Wost of U.S. coal production is surface-mined, shipped by radiogd, and used by alectric utiftites.

Note: Totals may not equal sum of components because of independent rounding.

Source: Energy Intormation Administration, Coal industry Amual 1998, DOEJEIA-0584(93) (Washington, DC, December 1994); Ouertenjy Coel Report October-December 1993, DOE/E(A.0121(98/4Q) (Nashington, DC, May 1994); and Form ElA.6, "Coal Distribution Feport." 
Table 25. Year-End Stocks of U.S. Coal by End-Use Sector, 1949-1993 (Million short Tons)

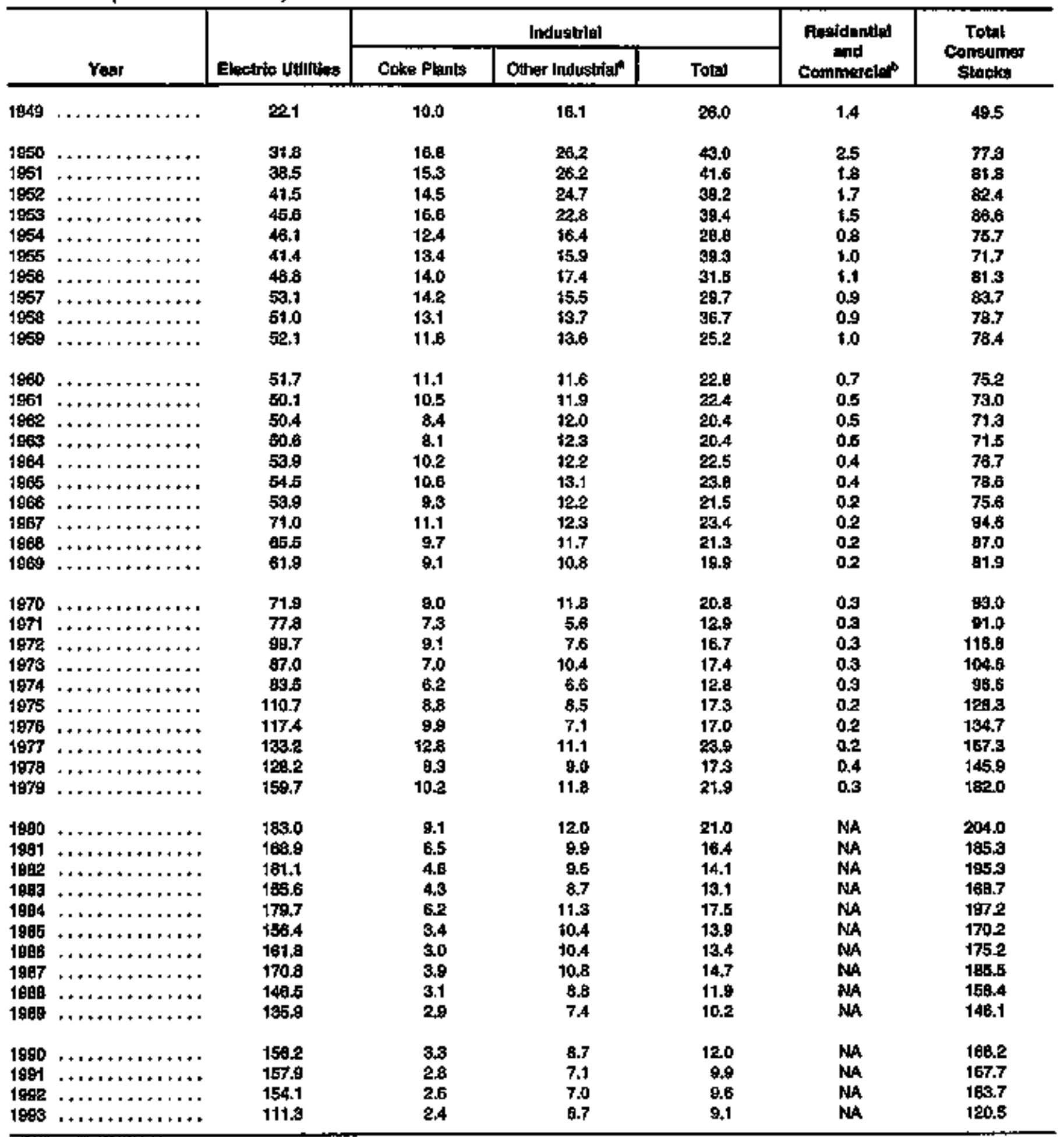

Inotudes transportation septor.

"Slook at reball doalecs.

NA - Not andiabto.

Noter Totels may not equal sum of components because of independent rounding.

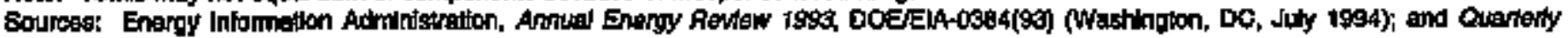

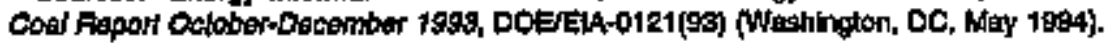


Table 26. U.S. Coke Supply and Dlsposition, 1949-1993 (Million Short Tons)

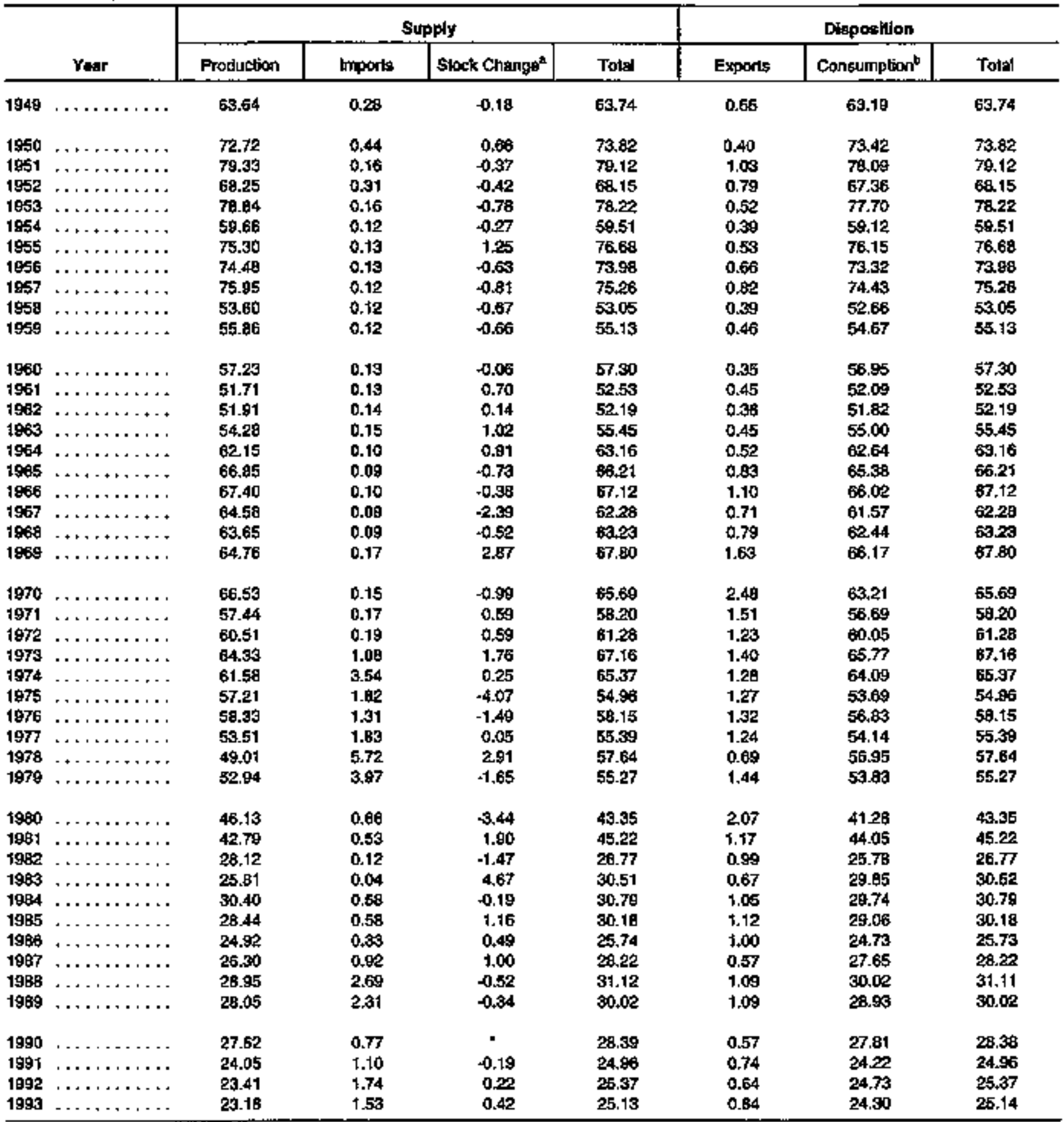

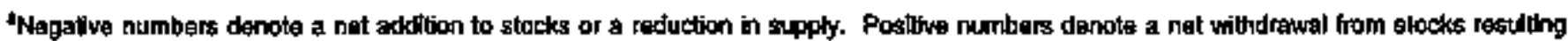
In an addition to supply. Includes producer and distributor stocks beginning in 1979.

Apparant consumption

Less than 0.01 millon shart tores.

Note: Tolats may not equal sum of components because to independent rounding.

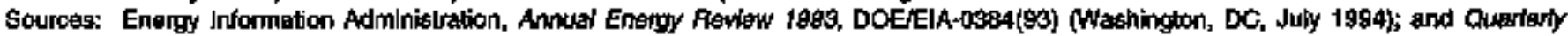

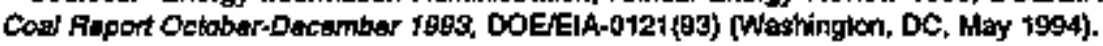


Table 27. U.s. Coal Consumption by End-Use Sector, 1949-1993 (Million Short Tons)

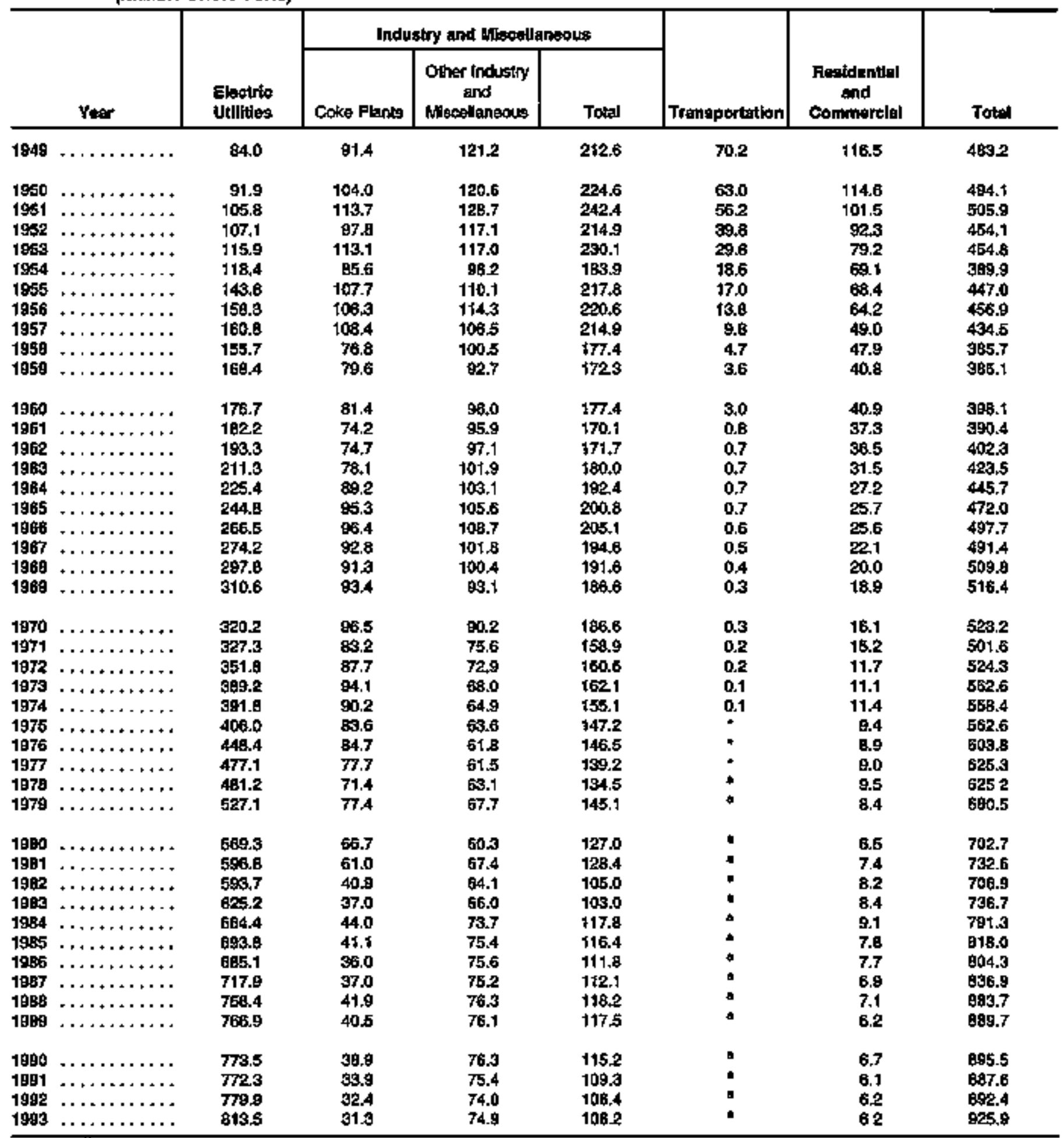

Included In the Other Industry and Maceltaneous category.

Less than 0.05 milien shopt tans.

Nole: Totels may not equad sum of components because of mdependeant rounding.

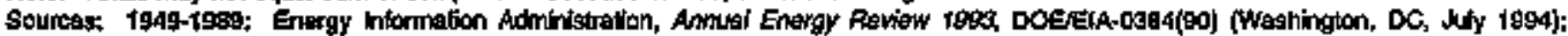

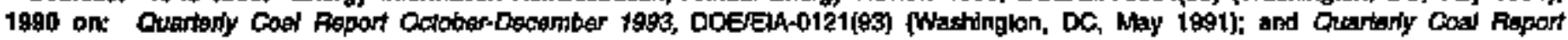

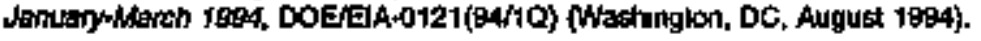


Figure 32. U.S. Cost Consumption by End-Uso Sector, 1950-1993

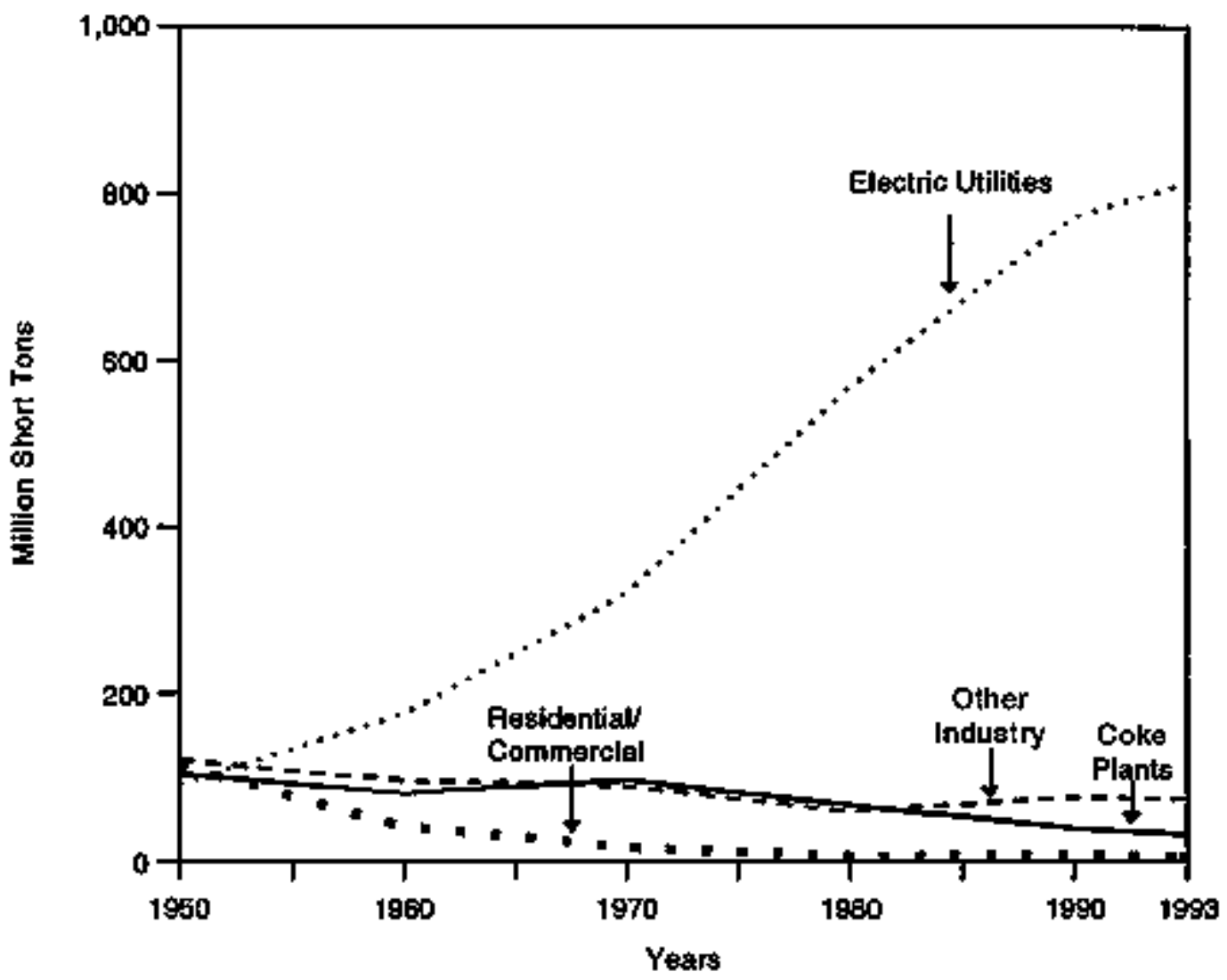

The pattem of U.S. cost consurnption has changed significantfy since 1950. Coal consumption has nisen mabily because more coal is used to genorate electricity.

Source: Enexgy Iniomation Adrinistration, Anmual Energy Review 1998, DOEJElA-0384(93)(Washinglon, DC, July 1994);

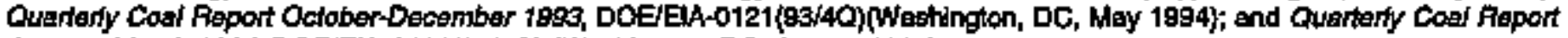
January-Merch 1994, DOE'ElA-0121(94/10) (Washington, DC, Augussi 1994). 
Table 28. U.S. Coal Consumption by Census Division and \$tate, 1989-1993 (Thoustand Short Tons)

\begin{tabular}{|c|c|c|c|c|c|}
\hline Cengut bligion sad Steto & 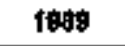 & 1890 & 1991 & 1982 & 1993 \\
\hline 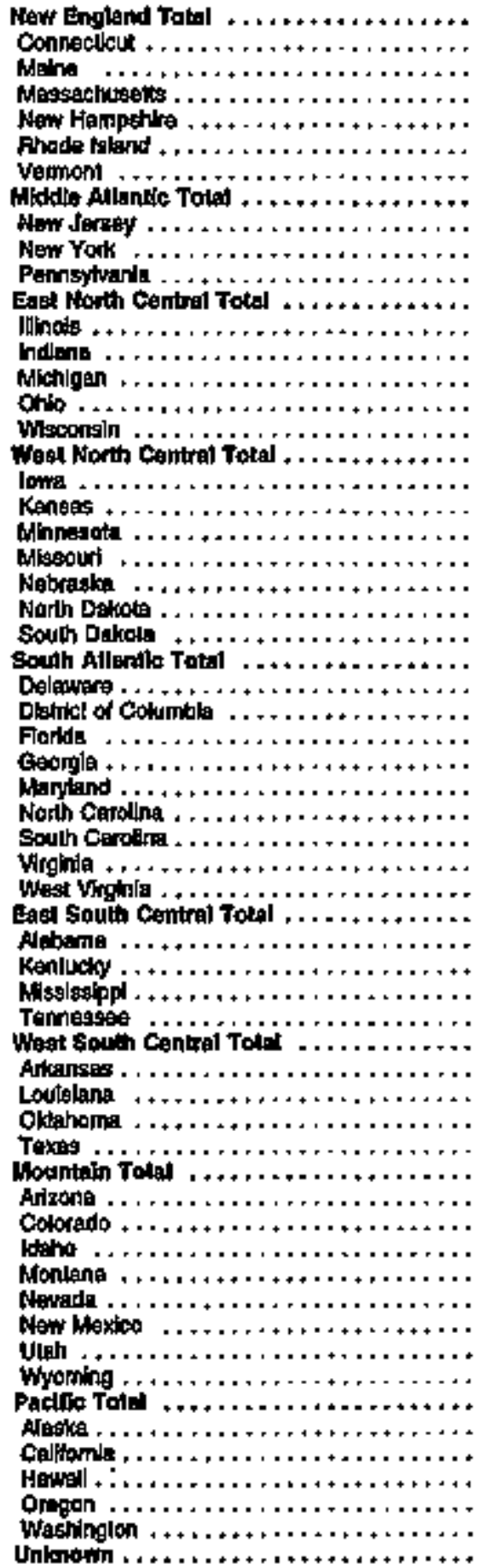 & 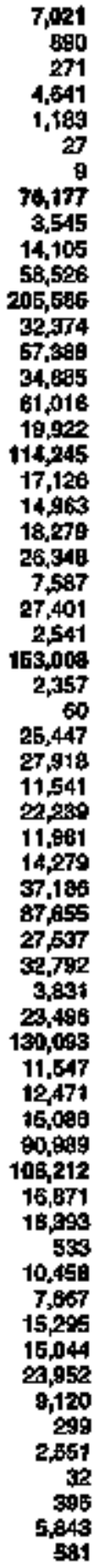 & 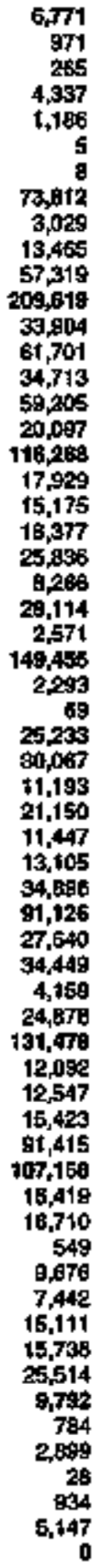 & 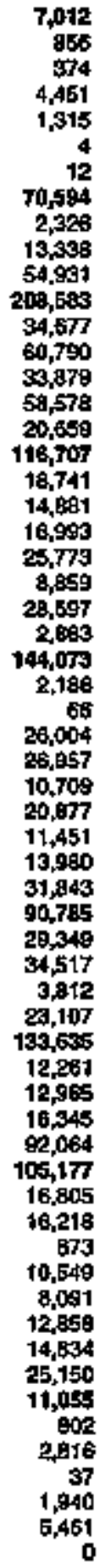 & 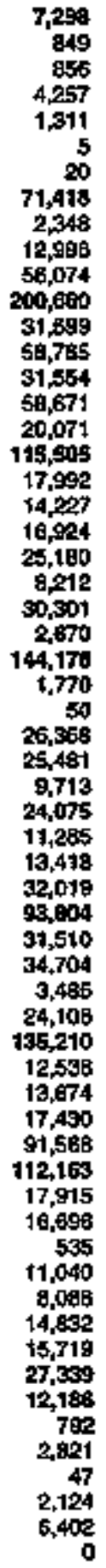 & 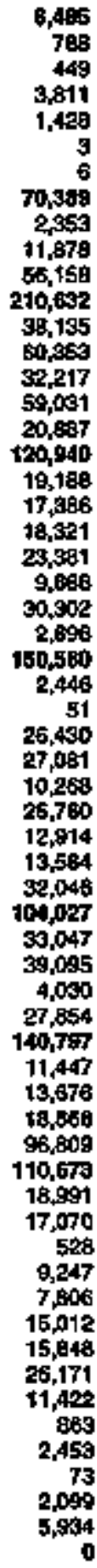 \\
\hline Uв, Tatal $\ldots \ldots \ldots \ldots \ldots \ldots \ldots \ldots$ & abg,680 & 885,480 & 807,621 & 1010,421 & 925,944 \\
\hline
\end{tabular}

Nole: Totals may nol equed aum of componath becauses al Indepondant rounding.

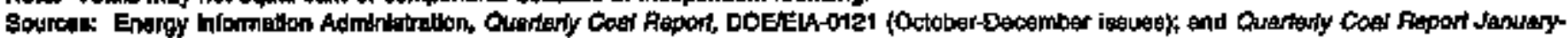
Merch rgs4, DoEtelaw12t(94/C) (Washington, DC, Augutst 1994). 
Table 29. U.S. Coal Consumption by End-Use Sector and by Census Division and State, 1993 (Thousand Short Tons)

\begin{tabular}{|c|c|c|c|c|c|}
\hline Census Divialian and State & Elentric Utilitias & coke Plantia & Other Indheshriat & $\begin{array}{l}\text { Pinsidentitial and } \\
\text { Cormmercibl }\end{array}$ & Total \\
\hline 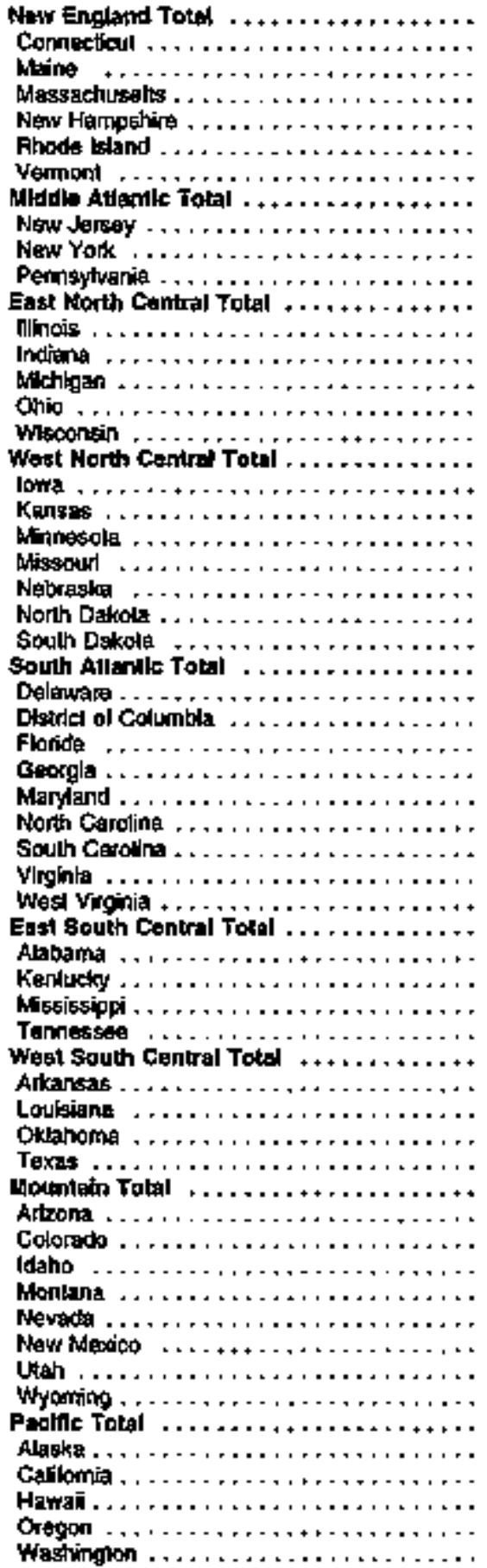 & 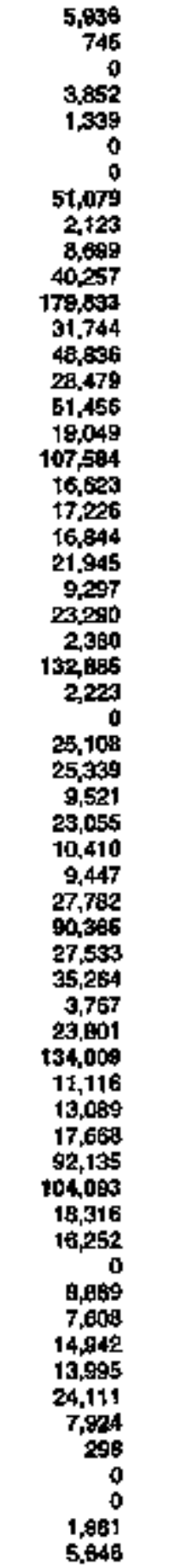 & 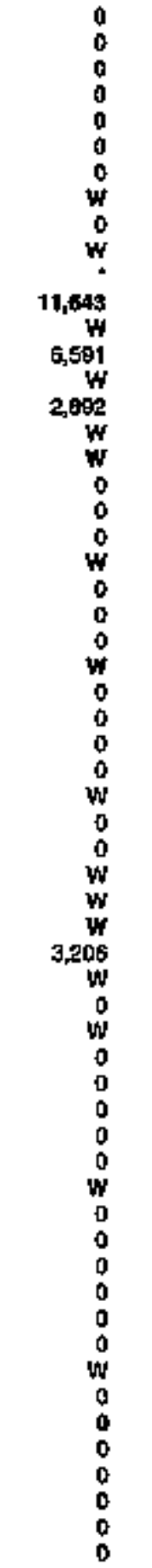 & 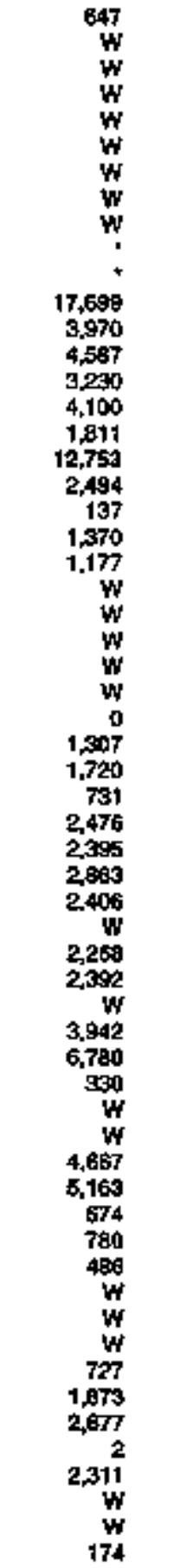 & 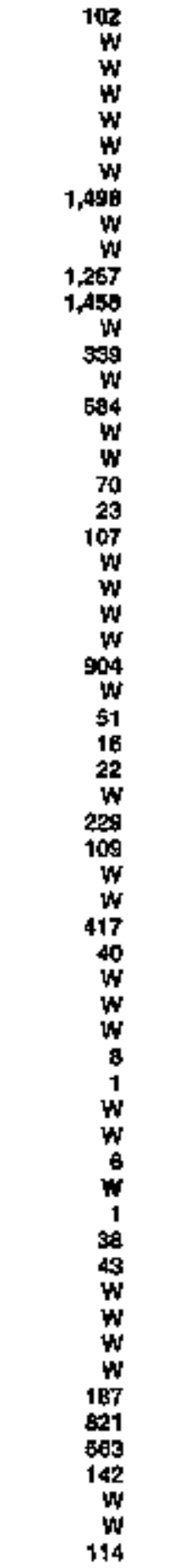 & 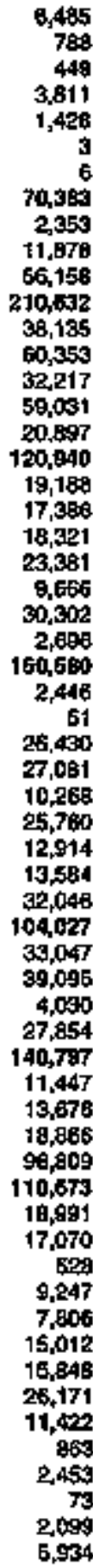 \\
\hline U.S. Tolat $\ldots \ldots \ldots \ldots \ldots \ldots \ldots \ldots$ & 813,506 & 31,323 & 74,892 & 6,221 & 925,944 \\
\hline
\end{tabular}

Less than 0.05 million short tons.

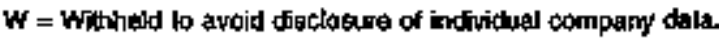

Note: Tolaks may not equal sum ol componesis because of Independant rounding.

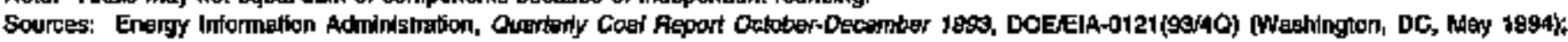

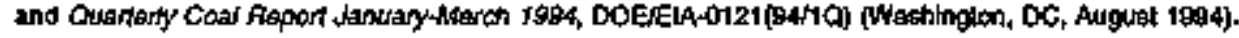


Flgure 33. Coalfired Cenerating Units: Number, Generating Capability, and Electricity Generation in J992 as Compared with Other Energy Sources

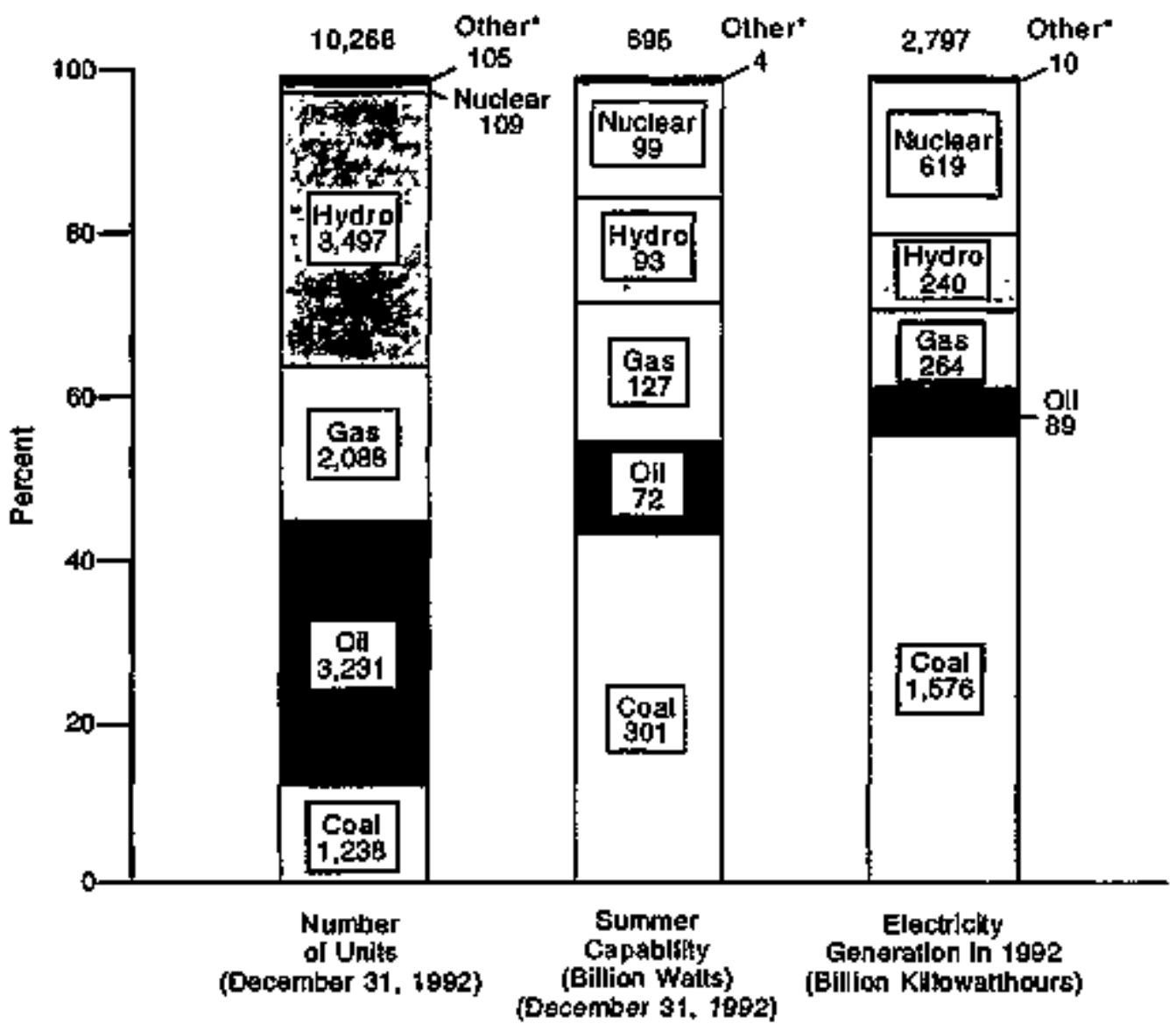

"Geothsmel, wood, wind. waste, refuse, and solar.

For their number and capobillty, coal-fired generating unts account for a large share of electrictly genesation. This is bocause they are mostly bese-losd units, operaling continuousty and supplying electricly at a generally constant rate.

Nole: Total may not equal sum of components the to independen: rounding.

Sources: Ensrgy Inlormation Administration, Inventory of Power Plants in the Unted States 1992, DOEfetA-0095(92) (Washington, DC, October 1993); and Monthly Energy Review diby 1994, DOEJELA-00315(94/O7) (Washington, DC, July 1994). 
Figure 34. Pereantage of Total Electricity Generating Cepability Using Coal, by State, December 3t, 1992

(Billion Short Tons)

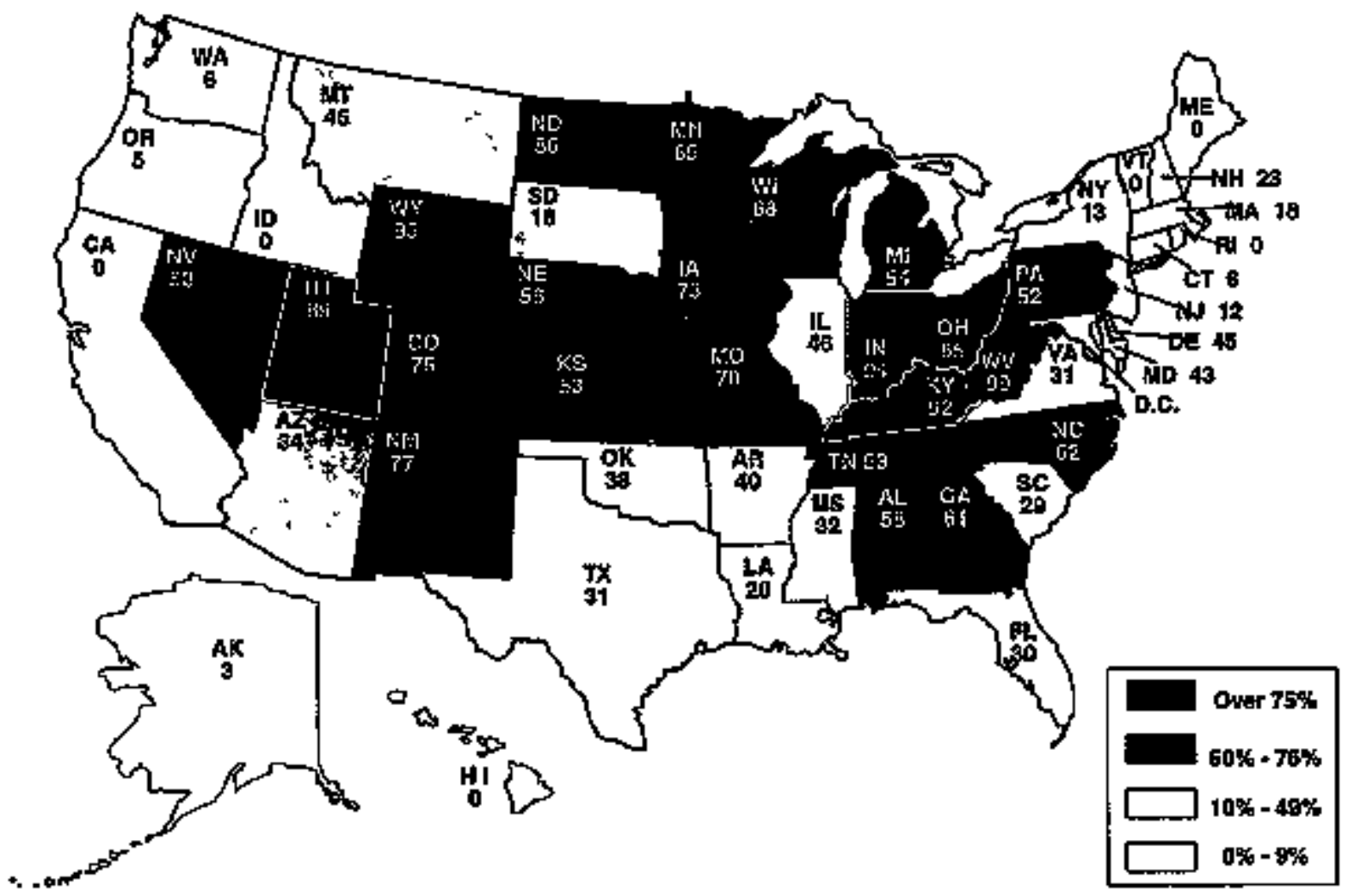

At the end of 1992, cast was the prinary fuel for 300,547 mejowalis of electric generaling capabsity, or 43 pentent of the U.S. total of 695,050 megawatts.

Sounce: Energy Information Administation, inventory of Power Plants in the United States 1992, DOEfElA-009(82) (Washington. DC, Oetober 1993). 
Table 90. U.S. Coal Prices, 1949-1993

(Dollars per Short Ton)

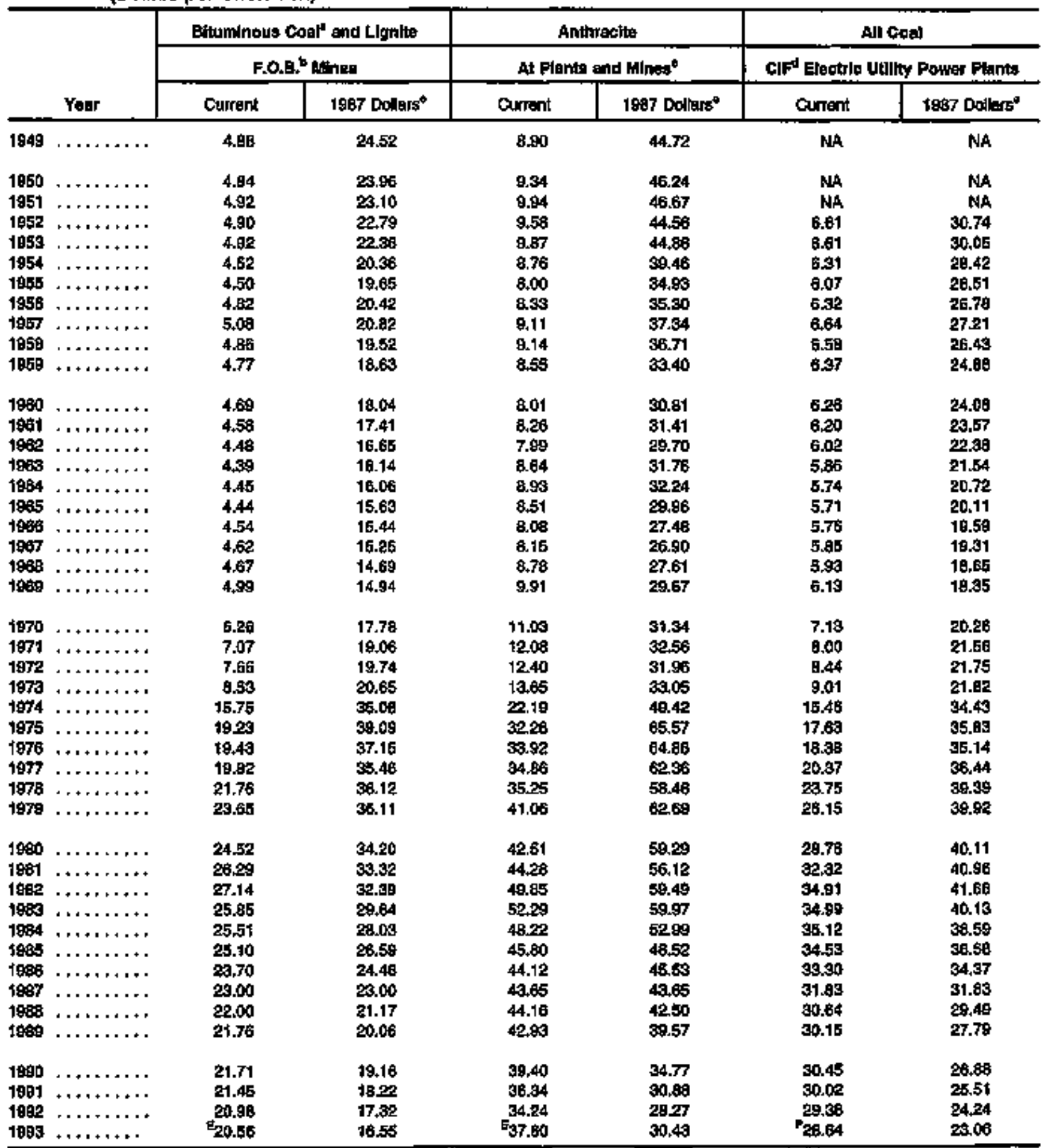

Inctudes atubltuminous cos.

Fieo an bogard.

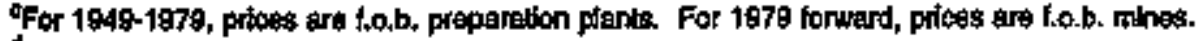

'Cost, insurance and froloth.

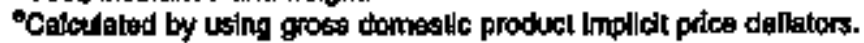

P - Prollintintry deta. E = Estimato. NA = Not avalabla.

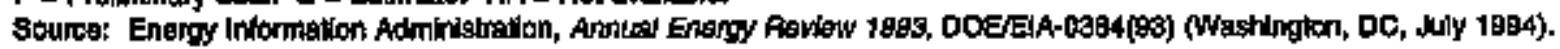


Table 37. Average Mine Price of U.S. Coal by Mining Method, 1980-1993

(Dollars per Short Ton)

\begin{tabular}{|c|c|c|c|c|}
\hline & Year & $\begin{array}{l}\text { Undwr- } \\
\text { groutind }\end{array}$ & 8urface & Total \\
\hline 1990 & $\ldots \ldots \ldots \ldots$ & 33.50 & 18.78 & 24.65 \\
\hline 1981 & $\ldots \ldots \ldots \ldots$ & 35.78 & 20.60 & 28,40 \\
\hline 1992 & $\ldots \ldots \ldots \ldots$ & 35.73 & 21.46 & 27.25 \\
\hline 1983 & $\ldots+\ldots \ldots \ldots$ & 34.47 & 20.68 & 25.98 \\
\hline $19 B 4$ & $\ldots \ldots+\ldots$ & 33.36 & 20.59 & 25.61 \\
\hline 1985 & $\ldots \ldots \ldots \ldots$ & $32.9 t$ & 20.13 & 25오이 \\
\hline 1988 & $\ldots \ldots \ldots$ & 30.33 & 19.34 & 23.79 \\
\hline 1987 & $\ldots \ldots \ldots \ldots$ & 29.65 & 18.58 & 23.07 \\
\hline 1938 & $\ldots \ldots \ldots \ldots$ & 28.97 & 17,43 & 20,07 \\
\hline 1989 & $\ldots \ldots \ldots$ & 28.44 & 17.38 & 21.82 \\
\hline 1990 & $\ldots \ldots \ldots$ & 26.58 & 16.98 & 21.76 \\
\hline 1991 & $\ldots \ldots \ldots \ldots$ & 28.53 & 18.60 & 21,49 \\
\hline 1992 & $\ldots \ldots \ldots \ldots$ & 27.83 & 16.34 & 21.03 \\
\hline 1993 & $\ldots+\ldots \ldots$ & $2 B .92$ & 15.67 & 19.85 \\
\hline
\end{tabular}

Nole: Average mine price is in current dotars.

Sources: Energy Infommation Administration, Cagl Production, DDEEEIA-0118, varfous losues; and Coat Indistry Annual 19gs, DOEEIA-0584(g9) (Waskington, DC, December 1984).

Table 32. Average Mine Price of U.S. Coat by Rank, t980-1993 (Dollars per Short Jon)

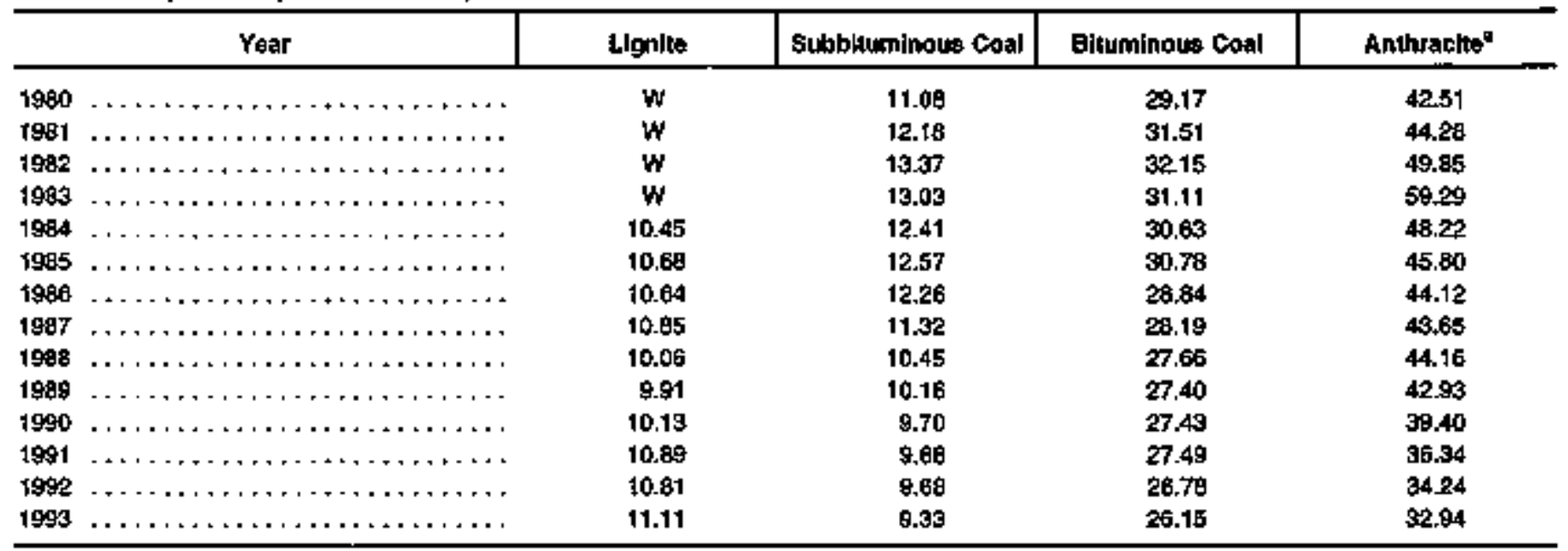

Produced in Pennsylvania.

Note: Average mine prica is in current dollars.

$W=$ Wiltheld to avold disclosure ol individuad company data.

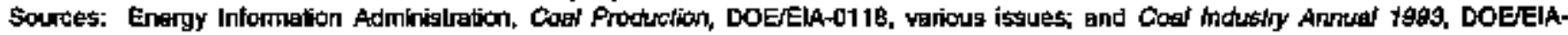
0584(93) (Washington, DC. December 1994). 
Table 33. Average Mine Price of U.S. Coal by State and Mining Method, 1993 (Dotlars Per Short Ton)

\begin{tabular}{|c|c|c|c|}
\hline \multirow[b]{2}{*}{ Strte } & \multicolumn{2}{|c|}{ Type of Mlining } & \multirow[b]{2}{*}{ Total } \\
\hline & $\begin{array}{l}\text { Undar- } \\
\text { gloutind }\end{array}$ & Sutteca & \\
\hline Alabema,$++\ldots+\ldots+\cdots++$. & 4200 & 4291 & 42.34 \\
\hline Alastia $\ldots \ldots \ldots \ldots \ldots$ & - & $\mathbf{W}$ & $W$ \\
\hline Anlzona $\ldots \ldots \ldots \ldots$. & - & W & $\mathbf{W}$ \\
\hline Adkansas $\ldots \ldots \ldots+\ldots+\ldots$ & - & W & W \\
\hline Coloredt $\ldots \ldots \ldots \ldots \ldots$ & 20.53 & 20.10 & 20.35 \\
\hline Innals $\ldots \ldots \ldots \ldots \ldots \ldots$ & 24.54 & 24.19 & 25.27 \\
\hline Inctana . . . . . . . . . . . & $W$ & $W$ & 22.89 \\
\hline lonua $\ldots \ldots \ldots \ldots \ldots$ & - & $W$ & $\boldsymbol{W}$ \\
\hline Kanstas $\ldots \ldots \ldots \ldots \ldots$ & - & W & W \\
\hline Kenhuchy Tolal $\ldots \ldots+\ldots \ldots$ & 25.07 & 24,35 & 24.77 \\
\hline Eestam $\ldots \ldots \ldots \ldots \ldots$ & 25.42 & 25.63 & 25.50 \\
\hline Wealem,$+\ldots+\ldots+\ldots++$. & 23.84 & 20.45 & 2238 \\
\hline Lotistand . . . . . . . . . . & - & $W$ & $w$ \\
\hline Mandand $\ldots \ldots \ldots \ldots \ldots$ & $w$ & $W$ & 25.21 \\
\hline Mssouri,$\ldots+\ldots++\ldots++$, & - & $W$ & $w$ \\
\hline Montana . . . . . . . . . & $W$ & $W$ & 11.05 \\
\hline Now Mexlo0 $+\ldots+++\ldots+\ldots$ & $w$ & $W$ & 27.96 \\
\hline Norlh Dakota $\ldots \ldots \ldots \ldots$ & 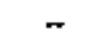 & 7.68 & 7.63 \\
\hline Ghis $\ldots \ldots \ldots+\ldots$ & 30.73 & 26.51 & 28.04 \\
\hline oktachome $\ldots \ldots \ldots \ldots$ & $W$ & $W$ & 24.81 \\
\hline Pennsytranla Total $\ldots \ldots \ldots$ & 27.35 & 25.09 & 26.50 \\
\hline Anthracte $\ldots \ldots \ldots \ldots \ldots$ & 38.02 & 3271 & 3294 \\
\hline Eluminous $\ldots \ldots \ldots \ldots . .$. & 27.29 & 23.65 & 26.03 \\
\hline Tennosese $\ldots \ldots \ldots \ldots \ldots$ & W & W & 27.23 \\
\hline Texes $\ldots \ldots \ldots \ldots \ldots$ & $*$ & t2.87 & 1287 \\
\hline What $\ldots+\ldots++\ldots+\ldots+$ & $\mathbf{2 0 . 8 1}$ & - & 20.81 \\
\hline Wighing $\ldots \ldots \ldots \ldots$ & 27,26 & 25,99 & 26,80 \\
\hline Wfastingiton $\ldots \ldots \ldots \ldots$ & 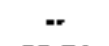 & Wr & $W$ \\
\hline West Wirginla $\ldots \ldots+\ldots$ & 28.54 & 25.57 & 27.58 \\
\hline Wyyoming $\ldots \ldots \ldots \ldots$ & W & W & 7,32 \\
\hline US Total $\ldots \ldots \ldots \ldots \ldots$ & 2652 & 15.67 & 19.85 \\
\hline
\end{tabular}

- = Not applicable.

$W=$ Whatheld to awold disctosure of individual company data.

Notes: Average mine price is it curent dollars.

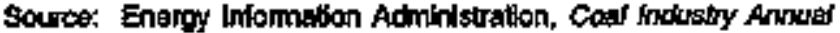
7993, DOEG
Table 34. Foreign Direct Irvestment in U.S. Coal, and Share of Totad U.S. Coal Production, 1980-1992

\begin{tabular}{|c|c|c|c|}
\hline & Yoar & $\begin{array}{l}\text { Foreign Direct } \\
\text { Imvestment in } \\
\text { US. Cows } \\
\text { (billon tollars) }\end{array}$ & $\begin{array}{l}\text { Foreign Shide of } \\
\text { US. Coot } \\
\text { Production } \\
\text { (percent) }\end{array}$ \\
\hline 1980 & $\ldots \ldots \ldots \ldots \ldots$ & 0.5 & 3.8 \\
\hline 1991 & $+\ldots+\ldots \ldots \ldots++$, & 1.1 & 12.9 \\
\hline 1992 & $\ldots \ldots \ldots \ldots \ldots$ & 1.2 & 16.6 \\
\hline 19993 & $\ldots, \ldots \ldots \ldots$ & 1,3 & 18.5 \\
\hline 1984 & $\ldots \ldots \ldots \ldots \ldots$ & 2.6 & 17,2 \\
\hline 1985 & $\ldots \ldots \ldots \ldots \ldots$ & 2.9 & $16 . B$ \\
\hline $19 \$ 5$ & $\ldots \ldots \ldots+\ldots+\ldots$ & 3.5 & 16.5 \\
\hline 1987 & $\ldots \ldots \ldots \ldots \ldots$ & $\mathbf{3 . 3}$ & 19.8 \\
\hline 1989 & $\ldots \ldots \ldots \ldots+\ldots \ldots$ & 5.3 & 20.6 \\
\hline 1989 & $\ldots \ldots \ldots \ldots \ldots$ & 0.9 & 21.2 \\
\hline 1990 & $+\ldots+\ldots, \ldots+\ldots++$ & 0.8 & 24.7 \\
\hline 1991 & $\ldots \ldots \ldots \ldots \ldots$ & 1.3 & 24.0 \\
\hline 1992 & $+\cdots+\ldots, \ldots+\cdots+$ & 1.6 & 26.0 \\
\hline
\end{tabular}

"Forelgn Direct Investument is the value of foreign parent companies' net equity in, and outstanding loans to, affiliates in the United Sieles at the end of the year. A U.S. afililate is a business arreprise in which a strigle foreign direct imsestor owns at least 10 percant of the woling securtites, or the equivelent.

burrent dollars.

Source: Energy Infomation Administration, Protiles of Foroign Divat investment in U.S. Energy 1992, DOEEIA-0466(02) (Washington, DC, hay 1994). 
Table 35. U.S. Coal Wining Cost Comparisons by Mining Methods (January 1989 Dollars per Short Ton of Raw Coal)

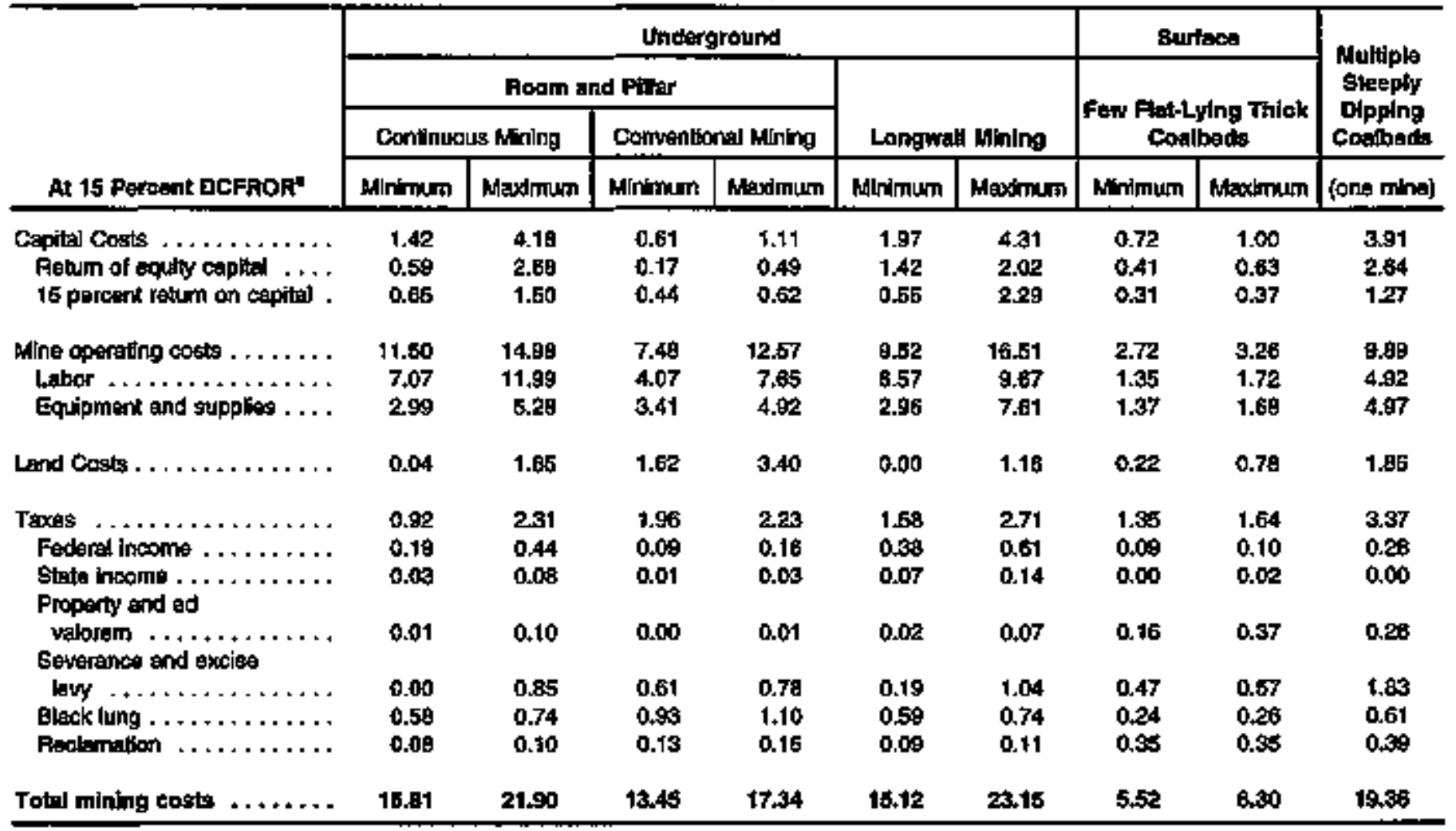

alocounted cesh flow rate of retum.

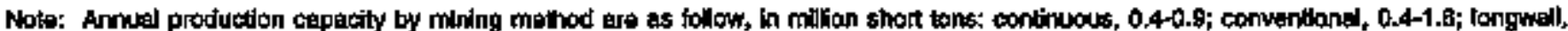

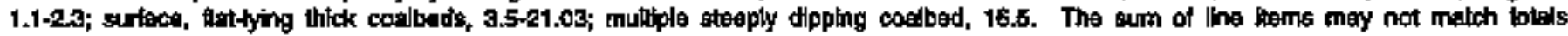
because llne itams and totals may be from dfferent mines.

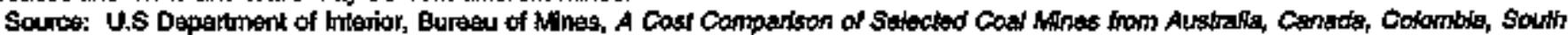

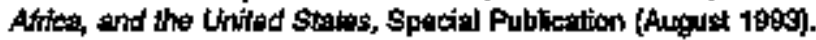


Tabje s6. Qually and Cost of Coal Recelpts of U.S. Electric Utillies of 50 Megawatts or Larger Nameplate Capactity by Coal Rant, 1990+1993

\begin{tabular}{|c|c|c|c|c|c|c|c|}
\hline \multirow[b]{2}{*}{ Coal Renk } & \multirow[b]{2}{*}{$\begin{array}{l}\text { Fecelpts } \\
\text { (thousend } \\
\text { short tons) }\end{array}$} & \multicolumn{4}{|c|}{ Averiagl Guallty } & \multicolumn{2}{|c|}{ Averag, Dellvered Coot" } \\
\hline & & $\begin{array}{c}\text { Btw } \\
\text { (per pound] }\end{array}$ & $\begin{array}{l}\text { Shbitt } \\
\text { (peroent by } \\
\text { melghi) }\end{array}$ & $\begin{array}{l}\text { Svifur } \\
\text { (pounds pes } \\
\text { mil:"on Btu) }\end{array}$ & $\begin{array}{c}\text { Ash } \\
\text { (pertant by } \\
\text { waighn) }\end{array}$ & $\begin{array}{l}\text { (cents par } \\
\text { millon Btu) }\end{array}$ & $\begin{array}{l}\text { (tiolarars per } \\
\text { short ton) }\end{array}$ \\
\hline \multicolumn{8}{|l|}{1980} \\
\hline Anthrachits $, \ldots, \ldots \ldots \ldots$ & 760 & 0,070 & 0.71 & 0.80 & 32.7 & 97.7 & 15.77 \\
\hline Batuminous $\ldots \ldots \ldots \ldots$ & $477,7 \mathrm{er}$ & 11,945 & 1.86 & 1.58 & 10.5 & 188.8 & 35.75 \\
\hline Subbluminous $\ldots \ldots \ldots \ldots$ & 232,660 & 0.741 & 0.43 & 0.50 & 72 & 130.5 & 29.34 \\
\hline Lignile $\ldots \ldots \ldots \ldots \ldots, \ldots$ & 75,492 & 6,439 & 0.92 & 1.46 & 14.0 & 98. & 12.65 \\
\hline Tatel $\ldots \ldots \ldots \ldots \ldots$ & 786,627 & 10,465 & 1.35 & 1.25 & 0.9 & 145.5 & 30.45 \\
\hline \multicolumn{8}{|l|}{1991} \\
\hline Anlthractito $\ldots \ldots+\ldots+\ldots$ & 723 & 7,981 & 0.64 & 0.82 & $\mathbf{3 9 . 4}$ & 94.1 & 14.98 \\
\hline Bhominorss $\ldots \ldots \ldots \ldots$ & 450,482 & $\$ 1,984$ & 1.84 & 1.50 & 10.3 & 150.2 & 36.66 \\
\hline Subbiuminous,$\ldots \ldots+\ldots+$ & 239,929 & 0,722 & 0,42 & 0.48 & 0.9 & 1323 & 23.00 \\
\hline Lonlls . . . . . . . . . . & 70,810 & 6,972 & 0.85 & 1.51 & 14.8 & 104.9 & 13.37 \\
\hline Totbl $\ldots \ldots \ldots, \ldots+\ldots$ & 789,829 & 10,579 & 1.30 & 1.2 & 9.8 & 144.7 & an.02 \\
\hline \multicolumn{8}{|l|}{1992} \\
\hline Anlhractet $\ldots \ldots \ldots \ldots$ & 503 & 8,470 & 0.67 & 0.81 & 32.0 & 93.7 & 15.88 \\
\hline Elanninkous $\ldots \ldots \ldots+\ldots+$ & 453,732 & 11,987 & 1.81 & 1.58 & 10.2 & 149.5 & \$5.96 \\
\hline Subbituminous $\ldots \ldots \ldots$ & 241,291 & 8,754 & 0.48 & 0.49 & 7,0 & 128.5 & 22,49 \\
\hline Lignniks $\ldots \ldots \ldots \ldots \ldots$ & 90,438 & 6,346 & 0.97 & 1.55 & 14.6 & 105.4 & 13.98 \\
\hline Total $\ldots \ldots \ldots \ldots \ldots$ & $\pi 7,963$ & 10,395 & 129 & 1.21 & 9.7 & 141.2 & 29.36 \\
\hline \multicolumn{8}{|l|}{1993} \\
\hline An'thracklot $\ldots \ldots \ldots \ldots$ & 392 & 8,267 & 0.89 & 0.84 & 39.9 & B1.1 & 16.05 \\
\hline Bhmintmotes $\ldots \ldots \ldots \ldots$ & 402800 & 12,042 & 1.71 & 1.44 & 10.2 & 147.6 & 35.55 \\
\hline Subbhuminous $\ldots \ldots \ldots$ & 205,180 & 8,769 & 0.49 & $\mathbf{0 . 4 7}$ & 7.0 & 12E.5 & 29.17 \\
\hline Lignitg $\ldots \ldots \ldots \ldots \ldots$ & EO,Bgo & 6,374 & 0.94 & 1.51 & 14.4 & 103.9 & 13.25 \\
\hline Tolal $+\ldots \ldots \ldots \ldots \ldots$ & 769,162 & 10,315 & 1.18 & 1.11 & 9.6 & 138.5 & 29.59 \\
\hline
\end{tabular}

DCurrent dollere.

tunclutes cultin and silt.

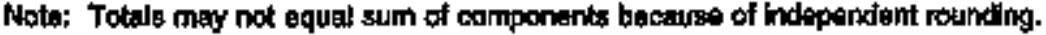

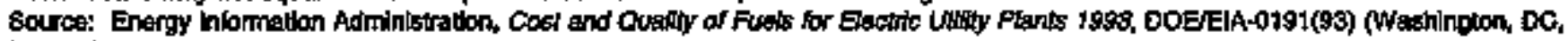
July 1994). 
Table 37. Cost of Contract and Spot Caal Becolpts at U.S. Electric Utilities of 50 Mfegawatts of Larger Nameplate Capacity, 1981-1993

\begin{tabular}{|c|c|c|c|c|c|c|}
\hline \multicolumn{2}{|r|}{ Yeer } & $\begin{array}{l}\text { Recelpots } \\
\text { (milion } \\
\text { hant tonst) }\end{array}$ & $\begin{array}{c}\text { Cost } \\
\text { (dollars per } \\
\text { short ton) }\end{array}$ & $\begin{array}{l}\text { Recolpts } \\
\text { (milion } \\
\text { shopt ions) }\end{array}$ & $\begin{array}{l}\text { Cost } \\
\text { (dollars per } \\
\text { shart ton) }\end{array}$ & $\begin{array}{l}\text { Avorage Cost } \\
\text { (dollas por } \\
\text { ahor lan) }\end{array}$ \\
\hline 1981 & $\ldots \ldots \ldots \ldots \ldots \ldots \ldots$ & 500.9 & 31.34 & 75.5 & 38.79 & 39.39 \\
\hline 1992 & $+\ldots \ldots+\ldots \ldots \ldots+\cdots+$ & 540.9 & 34.63 & 57,0 & 37.50 & 34.91 \\
\hline 1995 & $\ldots \ldots \ldots \ldots \ldots \ldots \ldots \ldots$ & 592.4 & 94.63 & 74.3 & 99.73 & 34.53 \\
\hline 1986 & $\ldots \ldots \ldots \ldots \ldots \ldots \ldots$ & 601.0 & 33.51 & $B 6.0$ & 31.81 & 33.36 \\
\hline 1997 & $\ldots \ldots \ldots \ldots \ldots \ldots+\ldots \ldots$ & 6102 & 3201 & $111+1$ & 30.96 & 31,83 \\
\hline 1880 & 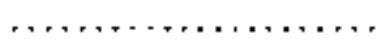 & 627.8 & $30.8 \mathrm{~g}$ & 100.0 & 29.90 & 30.64 \\
\hline 1989 & $\ldots \ldots \ldots \ldots \ldots \ldots \ldots \ldots$ & 620.0 & 30.38 & 139.3 & 29.07 & 30.15 \\
\hline 1980 & $\ldots \ldots \ldots \ldots \ldots \ldots \ldots$ & 6AB. & 30.74 & 138.0 & 29.11 & 30,45 \\
\hline
\end{tabular}

Hote: Cost is in curreni dollars.

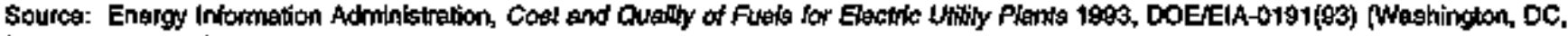
Juty 1994) and provtous issues. 
Table 38. U.S. Coal Recelpts and Price by Sulfur Content at Electrie Utility Plants, by State of Origin and Imports, 1993

\begin{tabular}{|c|c|c|c|c|c|c|c|c|c|}
\hline Stake & $\begin{array}{l}\text { Guanlity } \\
\text { [thoussard } \\
\text { shout lons) }\end{array}$ & $\begin{array}{c}\text { Cents } \\
\text { perr } \\
\text { MN Bu }\end{array}$ & $\begin{array}{l}\text { Quantity } \\
\text { (thousarnd } \\
\text { shor tons) }\end{array}$ & $\begin{array}{c}\text { Cents } \\
\text { per } \\
\text { MH BW }\end{array}$ & $\begin{array}{l}\text { Quanity } \\
\text { (blousant } \\
\text { ahort tons) }\end{array}$ & $\begin{array}{c}\text { Certs } \\
\text { per } \\
\text { Mly Ebs }\end{array}$ & $\begin{array}{l}\text { Ouantity } \\
\text { (thousand } \\
\text { elhont tons) }\end{array}$ & $\begin{array}{l}\text { Conts } \\
\text { per } \\
\text { Mat Btu }\end{array}$ & $\begin{array}{l}\text { Lbs, Sulfur } \\
\text { per } \\
\text { Wh Btu }\end{array}$ \\
\hline Alabame $\ldots \ldots$ & 5,000 & 252 & 11,102 & 178 & $\operatorname{seg}$ & 143 & 16,736 & 200 & 0.98 \\
\hline tilinots . . . . . . & 25 & 161 & 10,511 & 151 & 29,842 & 151 & 40,378 & 151 & 2.24 \\
\hline findlana . . . . . . & E33 & 199 & 2,594 & 121 & 19,784 & 129 & 22,910 & 123 & 2.80 \\
\hline town $\ldots \ldots \ldots$ & 0 & - & 0 & - & 18 & 175 & 18 & 175 & 3.11 \\
\hline Kansas $.+\cdots+$ & 0 & 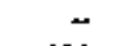 & 0 & - & 326 & 130 & 326 & 130 & 2.83 \\
\hline Kentuncky '.... & 14,880 & 161 & 69,812 & 156 & 34,963 & 129 & 119,755 & 147 & $t, 37$ \\
\hline Loulalena ..... & o & - & 2,662 & 139 & 441 & 142 & 3,103 & 139 & 1.12 \\
\hline North Dakoth .. & 0 & - & 25,227 & 74 & 523 & 77 & 25,750 & 74 & 1.15 \\
\hline Onlo ......... & 2 & $13 \mathrm{~g}$ & 1,794 & 120 & 28,471 & 143 & 28,267 & 142 & 2.61 \\
\hline Okklahome .... & 2 & 43 & 1 & 23 & 35 & 110 & $\mathbf{3 8}$ & 108 & 2.68 \\
\hline Pennsyhanle .. & 1,390 & 163 & 28,6 的 & 145 & 14,863 & 127 & 45,136 & 140 & 1.54 \\
\hline Tennesses .... & 129 & 130 & 1,678 & 139 & 162 & 110 & 1,968 & 136 & 1.07 \\
\hline Texas $\ldots \ldots$ & 0 & $\pi$ & 30,760 & 112 & 21,075 & 123 & 51,8399 & 116 & $1.6 \mathrm{~B}$ \\
\hline Gitah $\ldots+\cdots++$ & 15,091 & 119 & $\theta$ & 82 & 0 & - & $\$ 5,100$ & 119 & 0.41 \\
\hline Viglnta $\ldots .$. & 4,213 & 169 & 12,389 & 161 & 103 & 125 & 16,704 & 163 & 0.02 \\
\hline Weshington ... & 19 & 127 & 4,545 & 138 & 0 & - & 4,564 & 138 & 0.98 \\
\hline West Wirghla .. & 25,295 & 169 & 33,776 & 148 & 16,370 & 142 & 75,440 & 154 & 1.13 \\
\hline Wyoming $\ldots \ldots$ & 189,065 & 126 & 12792 & 95 & 0 & - & $20+, 858$ & 124 & 0.42 \\
\hline Impotte . . . . . & 3,816 & 183 & 811 & 153 & 0 & $=$ & 4,620 & 153 & 0.54 \\
\hline
\end{tabular}

$\sim$ = Not applicable.

Notos: Tolals mey not equal eum of components becauses of Independent raunding. NW Btu = m|Hion British themal units.

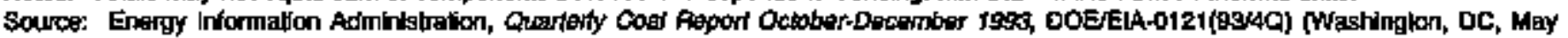
1994).

Table 39. U.S. Eleotricity Generation by Energy Source, Selected Years, 1980, 1985, 1990-1993 (Bilion Kilowatthours)

\begin{tabular}{|c|c|c|c|c|c|c|}
\hline Energy Source & 1980 & Iops & 1990 & 1981 & 1992 & 1993 \\
\hline Coal. & 1,162 & 1,402 & 1,5000 & 1,554 & 1,576 & 1,639 \\
\hline Nalurel Geg $\ldots, \ldots, \ldots, \ldots$ & 346 & 292 & 284 & 264 & 264 & 259 \\
\hline Petrotetm $\ldots \ldots \ldots \ldots \ldots$ & 246 & 100 & 117 & 111 & 89 & 100 \\
\hline Nuclas Power,$\ldots \ldots+\ldots \ldots$ & 251 & 3B4 & 577 & 613 & 610 & 610 \\
\hline Hyctoelectric Power . .......... & 276 & 281 & 280 & 276 & 240 & 265 \\
\hline Goothermtal Energy . . . . . . . . & 5 & 9 & $\theta$ & 8 & $\mathrm{~g}$ & 8 \\
\hline Other $\ldots \ldots \ldots \ldots$ & b & 1 & 2 & 2 & 2 & 2 \\
\hline Total,$\ldots \ldots \ldots \ldots \ldots \ldots$ & 2,236 & $\mathbf{2 , 4 7 0}$ & 2,808 & 2,825 & 2,797 & $2, \mathrm{Bgs}$ \\
\hline
\end{tabular}

Wood, wastr, whd, ghokswoitgic, and solar.

bess than 1 billon klowalthours.

Note: Totals may not equal sum of components because of independent rounding.

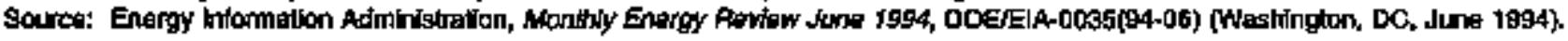


Table 40. Major U.8. Coal-Carrying Railroad Systems, 1993

\begin{tabular}{|c|c|c|}
\hline Failroad Syotem & $\begin{array}{l}\text { Cool } \\
\text { Originated" } \\
\text { (अillion short } \\
\text { lons) }\end{array}$ & $\begin{array}{l}\text { Percent } \\
\text { of Total }\end{array}$ \\
\hline \multicolumn{3}{|l|}{ Burilington Northom Ralroad } \\
\hline Company $\ldots \ldots \ldots \ldots \ldots \ldots \ldots$ & 148. & 27.9 \\
\hline CsX Transportatkon $\ldots \ldots+\ldots \ldots \ldots$, & 14B.2 & 27.8 \\
\hline Norfulk Gouthem Corporeltion $\ldots . .$. & 910.4 & 20.7 \\
\hline Consolidated fial Comporation . . . . . . . & 41.4 & 7.8 \\
\hline Denver, Alo Grand \& Weelem . . . . . . & 22.7 & 4.3 \\
\hline IIGroils Central Ratioad Company . . . . & 17.1 & 3.2 \\
\hline Unlan Pacillic Rellroed Compermy . . . . . & 15.8 & 3.0 \\
\hline Akchison, Topoka \& Sente Fe $\ldots . .$. & 14.1 & 2.6 \\
\hline Son the $+\ldots \ldots+\ldots \ldots \ldots+\ldots \ldots$ & 9.6 & 1.8 \\
\hline Top Nhe $\ldots \ldots \ldots \ldots \ldots \ldots \ldots$ & 528.1 & 99.0 \\
\hline Others $\ldots+\cdots+\ldots+\cdots+\cdots+\cdots$ & 5.5 & 1.0 \\
\hline Totrel & $5 \$ 3.6$ & 100.0 \\
\hline \multicolumn{3}{|c|}{ 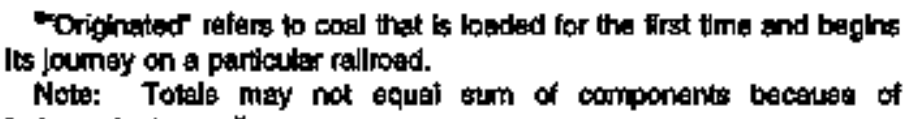 } \\
\hline
\end{tabular}

Table 41. U.S. Rail Transportatlon of Coel, 1980-1993

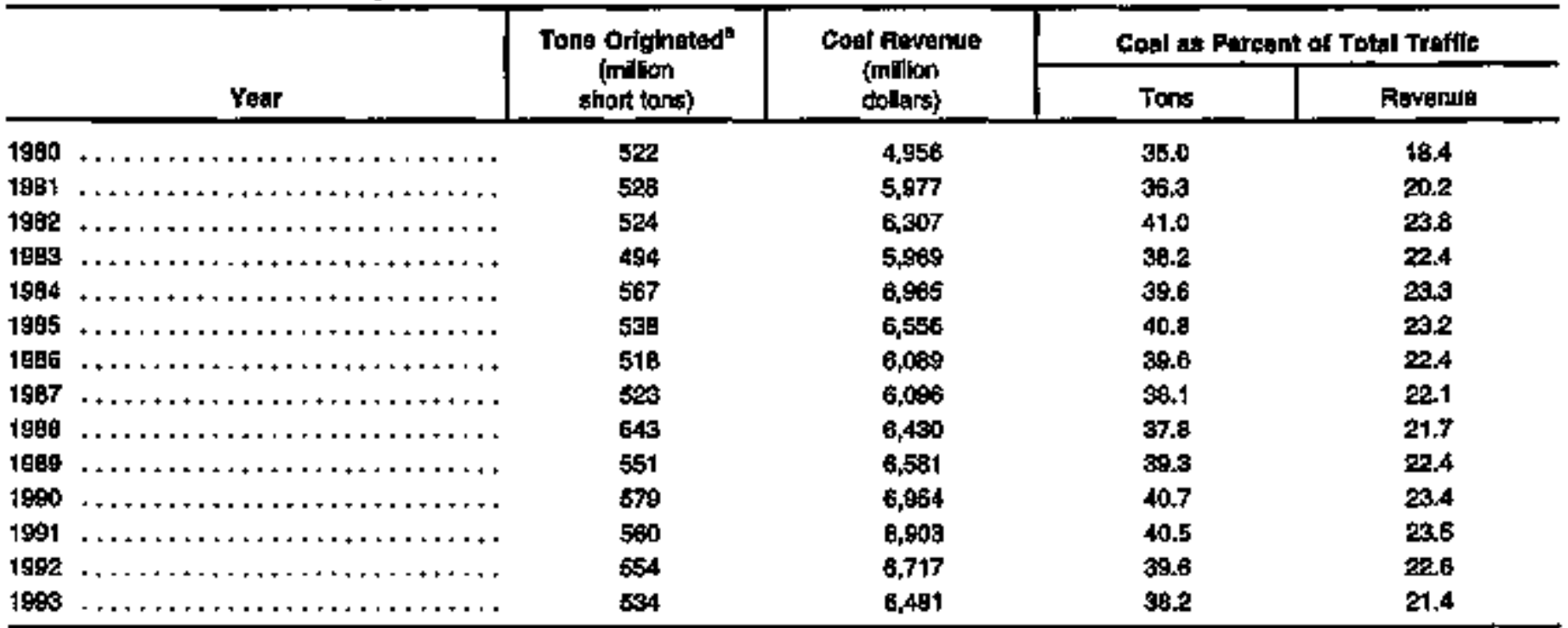

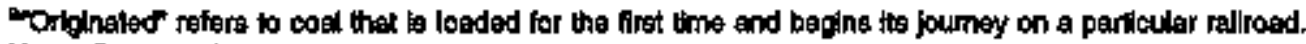
Nole: Rovenus is in curment dollers.

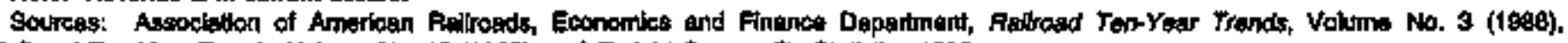

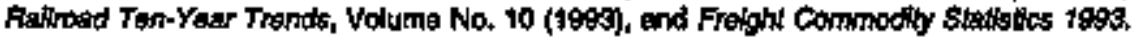


Table 42. Coal Handled and Revenue Received by Major U.S. Coal-Catrying Ralilroeds, 1993

\begin{tabular}{|c|c|c|c|c|}
\hline \multirow[b]{2}{*}{ Retitiand } & \multicolumn{2}{|c|}{ Coeh Drfginated" } & \multicolumn{2}{|c|}{ Coed Frvọnuts } \\
\hline & $\begin{array}{c}\text { Amount } \\
\text { (milion } \\
\text { shot tons? }\end{array}$ & $\begin{array}{l}\text { Shere of Al } \\
\text { Commodibso } \\
\text { (percent) }\end{array}$ & $\begin{array}{c}\text { Amount } \\
\text { (m) }\end{array}$ & $\begin{array}{l}\text { Shere of All } \\
\text { Commoditios } \\
\text { (peroent) }\end{array}$ \\
\hline Brailngion Nothem $\ldots \ldots \ldots \ldots \ldots \ldots \ldots$ & 148.8 & 55.2 & $1,575.9$ & 30 \\
\hline os $x$ Corporatton $\ldots \ldots \ldots \ldots+\ldots \ldots$ & 148.2 & 49.6 & $1,464,6$ & 29.9 \\
\hline Denver, flo Grande I Wottern . . . . . . . . & 2.7 & 84.3 & 144.2 & 40.1 \\
\hline Inhots Central Guif . . . . . . . . . . . . & 17.1 & 34.6 & 71.1 & 12.7 \\
\hline Urton Pacifle $\ldots \ldots \ldots \ldots \ldots \ldots \ldots \ldots$ & 15.8 & 10.4 & G72.9 & 16,8 \\
\hline Alatilson, Topeke 4 Bamla Fa $\ldots \ldots \ldots \ldots$ & 14,1 & 17.8 & 223.3 & B.7 \\
\hline Sootne $\ldots \ldots \ldots \ldots \ldots \ldots \ldots \ldots$ & 9.6 & 27.5 & 30.4 & E.1 \\
\hline
\end{tabular}

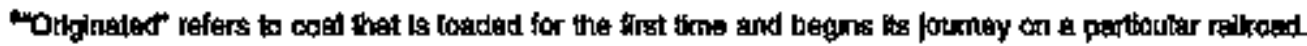

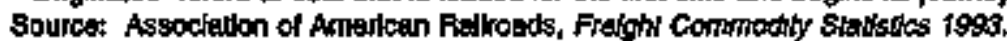

Table 43. U.S. Waterborne Traffic: Coal and Caal Coke as Compared with Other Fosell Fuele and Other Commodilies, 1991 (Million Short Tons)

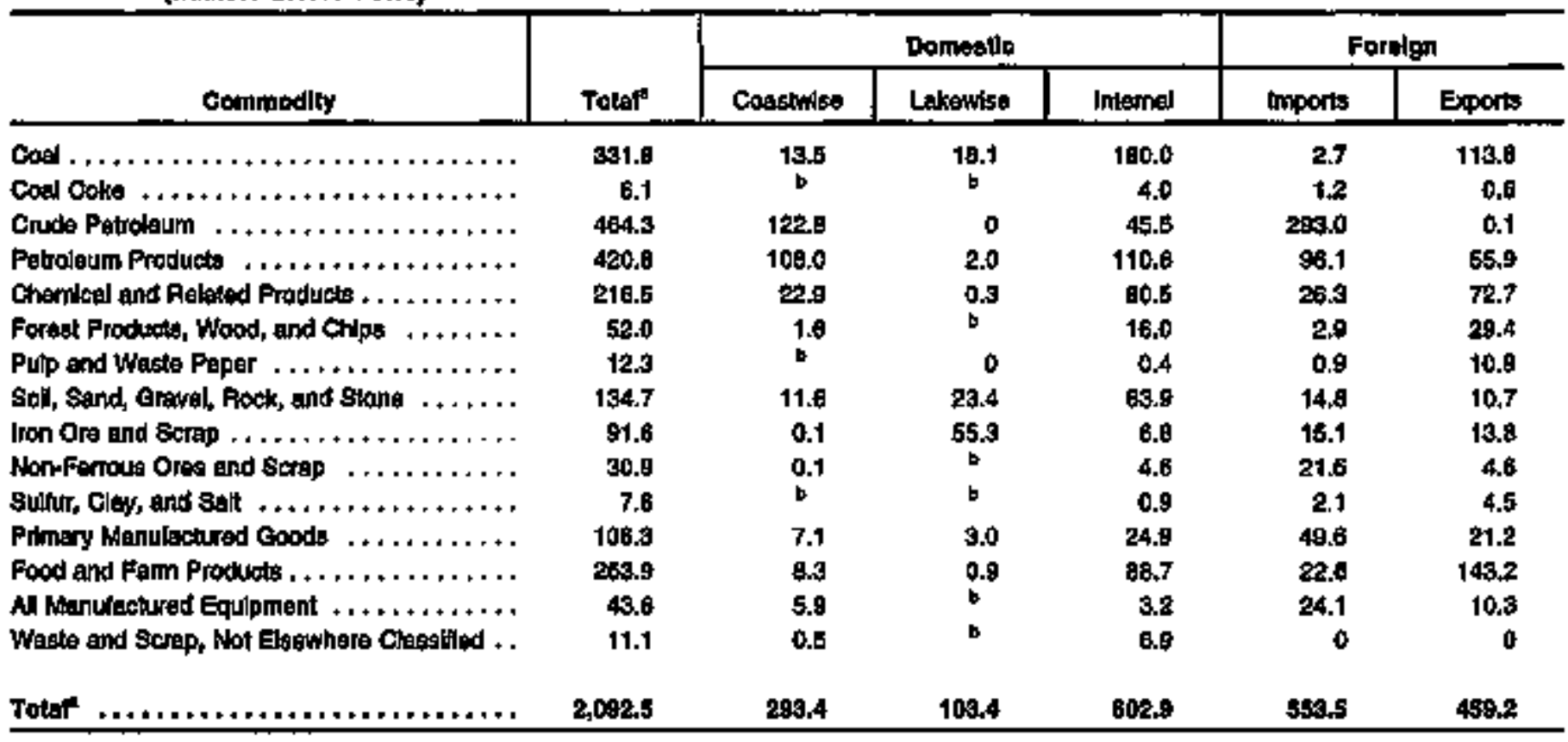

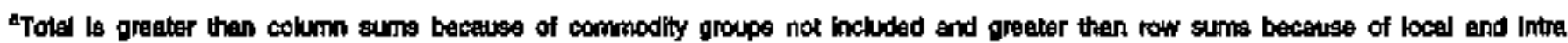
tantiontea nok Includedis.

Lesa than 100,000 tons.

Bource: U.S. Army Corpe of Engineers, Tha US. Wetenway Eystem-Facis (January 1984). 


\begin{tabular}{|c|c|c|c|}
\hline Port/Temintuat & $\begin{array}{l}\text { Existing Annus } \\
\text { Terminal Capecity } \\
\text { (milion short tons) }\end{array}$ & $\begin{array}{l}\text { Slarage } \\
\text { Capacity }\end{array}$ & $\begin{array}{l}\text { Serving } \\
\text { Aallroads }\end{array}$ \\
\hline $\begin{array}{l}\text { Baltimore, MD } \\
\text { Curtis Bay Chessie System } \ldots \ldots \ldots \ldots \ldots \ldots \ldots \ldots \\
\text { Curtis Bay Co. } \ldots \ldots \ldots \ldots \ldots \ldots \ldots \ldots \ldots \ldots \ldots \\
\text { Consol Marine Terminal } \ldots \ldots \ldots \ldots \ldots \ldots \ldots \ldots\end{array}$ & $\begin{array}{l}12.0 \\
10.0 \\
10.0\end{array}$ & $\begin{array}{l}100 \text { railicars } \\
350,000 \text { short tons } \\
750,000 \text { short tons }\end{array}$ & $\begin{array}{l}\operatorname{cs} x \\
\cos x \\
\text { confall, } \operatorname{csx}\end{array}$ \\
\hline $\begin{array}{l}\text { Newport Nẹws, VA } \\
\text { Pler } 9 \quad \ldots \ldots \ldots \ldots \ldots \ldots \ldots \ldots \ldots \ldots \ldots \ldots \ldots \ldots \\
\text { Dothinion Temingi } \ldots \ldots \ldots \ldots \ldots \ldots \ldots\end{array}$ & $\$ 2.0$ & $\begin{array}{c}\text { NA } \\
180 \text { railcars } \\
2,05 \text { milion short tons }\end{array}$ & $\begin{array}{l}\operatorname{cs} x \\
\operatorname{cs} x\end{array}$ \\
\hline $\begin{array}{l}\text { Morehead Cly, NC } \\
\text { North Carolia State Port Aulhority Bulk Facility . . . }\end{array}$ & 3.0 & NA & Noxfolk Southem \\
\hline 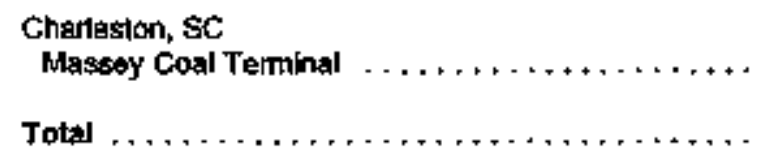 & $\begin{array}{r}2.5 \\
118.5\end{array}$ & $\begin{array}{l}300 \text { railears } \\
275,000 \text { short tons }\end{array}$ & $\begin{array}{l}\text { OSX; Norfolk } \\
\text { Southem } \\
-\end{array}$ \\
\hline $\begin{array}{l}\text { Missigsippi Rlver } \\
\text { Public Bulk Temminal (MGGO)" } \ldots \ldots \ldots \ldots \ldots \ldots\end{array}$ & 5.0 & 750,000 meinc tons & $\begin{array}{l}\text { CSX; Ilanois Central; } \\
\text { Kansas City Soulhem; } \\
\text { Noriolk Southem; Puific } \\
\text { Belt Southem Pacific; } \\
\text { Union Pacific }\end{array}$ \\
\hline $\begin{array}{l}\text { Electro-Coal } \ldots \ldots \ldots \ldots \ldots \ldots \ldots \\
\text { International Marine Terminat } \ldots \ldots \ldots \ldots \ldots\end{array}$ & 25.0 & $\begin{array}{l}4,500,000 \text { short tons } \\
1,500,000 \text { short tors }\end{array}$ & $\begin{array}{l}\text { None } \\
\text { Nonin }\end{array}$ \\
\hline At-Sea Oparation $\ldots \ldots \ldots \ldots \ldots \ldots \ldots$ & $1.0^{b}$ & -- & - \\
\hline $\begin{array}{l}\text { Bumside, LA } \\
\text { Bumside Tẹminal } \ldots \ldots \ldots \ldots \ldots \ldots \ldots \ldots \ldots\end{array}$ & 6.0 & 476,000 metrte $10 n$ s & Illinols Ceprtral \\
\hline $\begin{array}{l}\text { MAd-Stream Operation } \\
\text { Delle Trans, Cooperf. Smith, Pauling, \& Darrow ... }\end{array}$ & 56.5 & $\cdots$ & - \\
\hline
\end{tabular}


Table 44. U.S. Coal Export Loading Terminals, 1990 (Continued)

\begin{tabular}{|c|c|c|c|}
\hline PortrTerminal & $\begin{array}{l}\text { Exilding Annuxal } \\
\text { Tominal Capacity } \\
\text { (million short tons) }\end{array}$ & $\begin{array}{l}\text { Storage } \\
\text { Chapacity }\end{array}$ & $\begin{array}{l}\text { Serving } \\
\text { Pellirosds }\end{array}$ \\
\hline $\begin{array}{l}\text { Lake Charles, LA } \\
\text { Buk Terminal } \$ 1, \ldots \ldots \ldots \ldots \ldots \ldots \ldots \ldots\end{array}$ & 4.5 & 325,000 sharit tons & $\begin{array}{l}\text { Kansas Cty Southim; } \\
\text { Southem Pactict Union } \\
\text { Pacific }\end{array}$ \\
\hline $\begin{array}{l}\text { Houston, TX } \\
\text { Bulk Meterials rlandling Plam } \ldots \ldots \ldots \ldots \ldots \ldots\end{array}$ & 3.0 & 125 reilcars & $\begin{array}{l}\text { Alchileon, Topaka and } \\
\text { Santa Fe; Burlngton } \\
\text { Nonihem; Sautharn } \\
\text { Pacific: Union Pacilic }\end{array}$ \\
\hline Bulk Doak $2 \ldots+\ldots \ldots \ldots \ldots \ldots \ldots$ & $\$ .0$ & 2,000 raikars & $\begin{array}{l}\text { Corpus Chnlsti Teminal } \\
\text { Assn; Southem Paclic; } \\
\text { Texas Maxicagn; Union } \\
\text { Pacilic }\end{array}$ \\
\hline Total $+\ldots \ldots \ldots \ldots \ldots++++\ldots \ldots \ldots+\ldots \ldots$ & 152.5 & $*$ & - \\
\hline $\begin{array}{l}\text { WEST COAST } \\
\text { LOS Angefes, CA } \\
\text { Berth } 49-\text { SO } \ldots \ldots \ldots \ldots \ldots \ldots \ldots \ldots \ldots \ldots\end{array}$ & 5.5 & 170,000 meiric tons & $\begin{array}{l}\text { Atchioon Topeka and } \\
\text { Santa Fe: Sounhem } \\
\text { Pacilic; Union Pacilic }\end{array}$ \\
\hline $\begin{array}{l}\text { Seward, AK } \\
\text { Sewand Colal Terminted } \ldots \ldots \ldots \ldots \ldots \ldots \ldots\end{array}$ & 3.3 & 120,000 metik tons & Alaska Rallrogd \\
\hline Total,$\ldots+\ldots \ldots \ldots \ldots \ldots \ldots \ldots \ldots \ldots \ldots+$ & 16.5 & - & - \\
\hline $\begin{array}{l}\text { QREAT LAKES } \\
\text { Con Rial Dock, Astababila } \ldots \ldots \ldots \ldots \ldots \ldots \ldots\end{array}$ & 7.0 & 1,500,000 short tons & CONRAIL \\
\hline Pttsburgis \& Conneaut botk Co., Conneant ....... & 13.5 & $6,000,000$ short tons & $\begin{array}{l}\text { Bessisaruer \& Lake } \\
\text { Erie }\end{array}$ \\
\hline Codan Marine, Erie $\ldots \ldots \ldots \ldots \ldots \ldots \ldots+\ldots \ldots$ & 0.4 & to0,000 shout tons & CONAAIL \\
\hline Lower Lake Dock Co., Sandusky $\ldots \ldots \ldots \ldots+\ldots \ldots$ & 7.5 & $\begin{array}{l}1,000,000 \text { shon } \\
\text { tons + raikess }\end{array}$ & Norfolk Soulhem \\
\hline Toledo Docks, Toledo . . . . . . . . . . . . . . . & 16.0 & 400,000 short tons & CONRAIL; CsX \\
\hline
\end{tabular}


Table 44. U.S. Coal Export Loading Temminals, 1990 (Continued)

\begin{tabular}{|c|c|c|c|}
\hline \multicolumn{4}{|l|}{ Other Coal Terminals } \\
\hline KCBX south Chicago $\ldots \ldots \ldots \ldots \ldots \ldots \ldots$ & 8.0 & $\begin{array}{l}460,000 \text { short tons + } \\
\text { railcars }\end{array}$ & $\begin{array}{l}\text { Belt Lini Raikway } \\
\text { Go. of Chicago }\end{array}$ \\
\hline Superior Mitwest Energy Terrininal Supenrior . . . . . . & 18.0 & $7,000,000$ short tons & Burtington Northem \\
\hline $\begin{array}{l}\text { Total Othar Tomlnals } \ldots \ldots \ldots \ldots \ldots+\ldots \ldots \ldots \ldots+ \\
\text { Grand Tolal Greal Lakes Ports } \ldots \ldots \ldots \ldots \ldots \ldots \ldots\end{array}$ & $\begin{array}{l}28.0 \\
70.4\end{array}$ & $\overline{-}$ & $\overline{-}$ \\
\hline Us. TOtAL $\ldots \ldots \ldots \ldots \ldots \ldots \ldots \ldots++\ldots \ldots \ldots$ & 357.9 & - & - \\
\hline
\end{tabular}

"Tenringl is actually on the Missisipipi River Cutf Outlet.

DAt-sea tranșier tapability from sala-going bargas.

ANumber of raikears not reparted.

"Grisat Lakes ports are restricted in vessed size to the allowable St. Lawrence Seaway dock dimensions of 730 18et in length, 76 feet bosm, and 25 feot draft.

- = Not appliczible.

NA = Not avaiable.

Sourc: U.S. Department of Transpotation, Marlíme Adminktraton, Ofilce of Porl and Intemmodel Development Existing and Potentiel U.S. Coed Export Loading Teminals (Washington, DC, January 1992). 
Table 45. U.S. Coal Exports by Country of Destingtion, 1960-1998 (Million Short Tons)

\begin{tabular}{|c|c|c|c|c|c|c|c|c|c|c|c|c|c|c|c|c|}
\hline & & & & & & & & Europ & & & & & & & & \\
\hline & Year & conachan & Eracti & $\begin{array}{l}\text { Lowem: } \\
\text { bourg }\end{array}$ & Denmak & Franed & Gemany & Itaty & $\begin{array}{l}\text { Mothen } \\
\text { tands }\end{array}$ & Spain & $\begin{array}{l}\text { United } \\
\text { Kingatiom }\end{array}$ & OAluer & Tolal & Japen & Ouher & Tot:A \\
\hline 1900 & $\ldots \ldots \ldots$ & 12.0 & 1.1 & 1.1 & 0.1 & 08 & 46 & 4.9 & 2.8 & 0.3 & 0 & 2.4 & 17.1 & 5.6 & 1.3 & 39.0 \\
\hline $198 x$ & $+\ldots+\ldots+\cdots$ & 12,1 & 1,6 & 10 & a.t & 0.7 & 43 & 48 & 26 & 02 & 0 & 20 & 15.7 & 0.6 & 1,0 & 36.4 \\
\hline 1992 & $\ldots \ldots \ldots+$ & 12.3 & 1.3 & 1.3 & b & 0.9 & 5.1 & B.0 & 33 & as & $b$ & 1.8 & $18 \%$ & 6.5 & 10 & 40.2 \\
\hline 190s & $\ldots \ldots \ldots$ & 14.6 & 1.2 & 2.7 & b & 27 & 5.6 & 7.9 & 5.0 & 1.5 & $b$ & 2.4 & 27.7 & 0.1 & 0.0 & 50,4 \\
\hline 1964 & $\ldots \ldots, \ldots+$ & 14,8 & 1.1 & 23 & D & 2.2 & 5.2 & B.1 & $\mathbf{d . 2}$ & 1.4 & 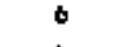 & 2.5 & 280 & 6.5 & 1.1 & 49.5 \\
\hline 1805 & $\ldots \ldots \ldots$ & 16.3 & 12 & 22 & b & 27 & 4.7 & 0.0 & 3.4 & 1.4 & D & 2.3 & 25.1 & 7.5 & 0.0 & 51,0 \\
\hline 1906 & $\ldots+\ldots+\ldots++$ & 16.5 & 1.7 & $1+3$ & b & 1.6 & 4.9 & 78 & 32 & 1.2 & $b$ & 2.5 & 23.1 & 7.8 & 1,0 & $\$ 0,1$ \\
\hline 1807 & $\ldots \ldots \ldots$ & 16.8 & 1.7 & 1.4 & 0 & 21 & 4.7 & 6.6 & 2.2 & 10 & 0 & 21 & 18.4 & $12 \boldsymbol{Z}$ & 1.0 & 50.1 \\
\hline 1988 & $\ldots, \ldots, \ldots$ & $\$ 7,1$ & 1,a & $1+1$ & b & t.s & $3 \mathbf{0}$ & 4.3 & 15 & 1,5 & $b$ & $\mathbf{t}, \boldsymbol{\theta}$ & 15.5 & 15,0 & 0.0 & 51,2 \\
\hline 1900 & n........ & 17.3 & 1.8 & 0.0 & 0 & 23 & 3.5 & 3.7 & 10 & 1.8 & b & 1.3 & 152 & 21.4 & 1.2 & 589 \\
\hline 1970 & $+\ldots+\cdots+\cdots$ & 10.1 & 2.0 & 1.0 & b & 3.6 & 6.0 & 4.3 & 2.1 & 32 & b & 1.8 & 25.9 & 27.6 & 1.2 & $71+7$ \\
\hline 997 & $+\ldots \ldots \ldots+$ & $\tan$ & 1,8 & 0.8 & 0 & 32 & 2.9 & 27 & 1.6 & 2.6 & t.7 & ixt & 166 & t9.7 & t.t & 67.3 \\
\hline 1972 & $\ldots \ldots \ldots \ldots$ & 187 & 1.9 & 1.1 & b & 1,7 & 24 & 3,7 & 2.3 & 2.1 & 2.4 & 1.1 & 16.0 & 18.0 & 1.2 & 58,7 \\
\hline 1973 & $\ldots \ldots \ldots$ & 167 & 1.6 & 1.2 & 0 & 20 & 1.6 & $3 \cdot 3$ & $1 . g$ & 2.2 & 0. & 1.3 & 14.4 & 19.3 & 1.6 & 50.6 \\
\hline 1974 & $\ldots \ldots \ldots$ & $\$ 4.2$ & 1,3 & 9.1 & 0 & 27 & 15 & 3.9 & 26 & 2.0 & 1.4 & 0,0 & 16.1 & 273 & 1.8 & 60.7 \\
\hline 1975 & $\ldots \ldots \ldots$ & 17.3 & 2.0 & 0.8 & 0 & 3.6 & 2.0 & 4,5 & 2.1 & 2.7 & $\$ . \theta$ & 1,0 & 190 & 25.4 & 2.6 & BB,3 \\
\hline 1978 & $\cdots+\cdots+\cdots$ & 18.9 & 2.2 & 2.2 & b & $\mathbf{3 . 5}$ & 1.0 & 42 & 3.5 & 2.5 & 0.8 & 2.1 & 109 & 188 & 21 & 600 \\
\hline 1977 & $\ldots \ldots \ldots$ & 17,7 & 2.3 & 1.5 & 0.1 & 23 & 0.9 & 4.1 & 20 & 1.6 & 0.6 & 2.1 & 150 & 15.9 & as & 54.3 \\
\hline 1978 & $\ldots \ldots \ldots$ & $\$ 6.7$ & 1.5 & $1 . t$ & b & 1.7 & 0.6 & 3.2 & t.1 & 0.8 & 0.4 & 2.2 & 11.0 & 10.1 & 2.6 & 40.7 \\
\hline 1979 & $n+\ldots+n+n$ & 19.5 & 28 & 3.2 & 0.2 & $\mathbf{3 9}$ & $2 B$ & 5.D & 20 & 1.4 & 1.4 & 4.4 & 23.9 & 15.7 & 4.1 & 60.0 \\
\hline 1980 & $n+\cdots+\cdots+\ldots$ & 175 & 3 & 4.8 & 1.6 & 7.8 & 26 & 7.1 & 4.7 & 3.4 & 4.1 & 6.0 & 41.9 & 23.1 & B.0 & 91.7 \\
\hline 1981 & $+\ldots+\ldots \ldots$ & 10.2 & 2.7 & 4,3 & 3.9 & 2.7 & 4.3 & 10.5 & 68 & 6.4 & 2.3 & e.t & 57.0 & 250 & B.7 & 113.8 \\
\hline 1992 & $\ldots \ldots \ldots$ & 16.8 & 3.1 & 4.0 & 2.8 & 0.0 & 23 & 11,3 & $5 . \theta$ & 6.0 & 20 & 7.6 & 51,3 & 25.8 & 7,5 & 1063 \\
\hline 1983 & $\ldots+\ldots+\ldots+\infty$ & 17.2 & 3.6 & 25 & 1.7 & 4.2 & t.s & B.1 & 42 & 30 & 1.2 & 6.4 & 33.1 & 17.9 & B.1 & 78 \\
\hline 1064 & $\ldots \ldots \ldots$ & 20.4 & 4.7 & 30 & 0.6 & 3.8 & 0.8 & 7.6 & s.5 & 2.3 & 28 & 53 & 328 & 16.3 & $\boldsymbol{7 . 2}$ & at.s \\
\hline 1985 & $-+\ldots \ldots+\ldots$ & 16.4 & 5.4 & 4.4 & 2.2 & 4.6 & $1 . t$ & 10.3 & 63 & 3.6 & 2.7 & 103 & 45.1 & 15.4 & 9.9 & 827 \\
\hline 1088 & $\ldots \ldots \ldots$ & 14.5 & 6.7 & 4,4 & $2 x$ & 54 & 0.8 & 10.4 & 5.6 & 2.6 & 29 & 9.4 & 426 & 11.4 & 114 & 85.5 \\
\hline $\operatorname{tg} 97$ & $\ldots \ldots \ldots \ldots$ & 16.2 & 58 & 4.8 & 0.9 & 29 & 0.5 & 0.5 & 4.1 & 2.5 & 2.6 & 6.8 & 34.2 & 11.1 & 12.3 & 70.6 \\
\hline 7998 & $\ldots \ldots \ldots$ & 18.2 & 5.3 & 6.5 & 20 & 4.3 & 0.7 & 11,1 & 5.1 & 2.5 & 3.7 & g.s & 45,1 & 14.1 & 11.3 & 钻o \\
\hline 19gs & $\cdots+\ldots+\ldots$ & 18. & 5.7 & 7.1 & 3.2 & 6.6 & 0.7 & 11.2 & 6.1 & 3.3 & 4.6 & e.9 & 61.6 & 13.8 & 12.0 & 100.8 \\
\hline 1990 & $+\cdots+\cdots+\cdots$ & 15.6 & Es & a.5 & 3.2 & 6.9 & 1,1 & $11, \theta$ & 6.4 & 30 & 5.2 & 9.5 & 504 & 13.3 & 12.7 & 105.8 \\
\hline 1890 & nentenes & 11.2 & 7.1 & 7.5 & 4,7 & $\mathbf{g . 5}$ & 1.7 & 11.3 & 9.5 & 4.7 & 6.2 & 10.4 & 05.5 & 12.3 & 130 & 109.0 \\
\hline $19 \mathrm{ga}$ & $\ldots \ldots \ldots$ & 15.1 & 6.4 & 72 & 3.0 & 8,1 & 10 & 9.3 & 9.1 & 4.5 & $\mathbf{5 . 5}$ & 2.5 & 57,3 & 12.8 & 11.4 & 1025 \\
\hline 1989 & $n_{++\cdots++\cdots}$ & 0.9 & 5.2 & 52 & 0.3 & 4.0 & 0.5 & 6.9 & 6.6 & 4.1 & 4.1 & 6.9 & $\$ 7,6$ & 11.9 & 10,9 & 745 \\
\hline
\end{tabular}

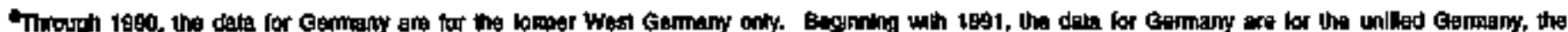

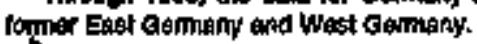

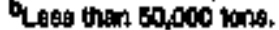

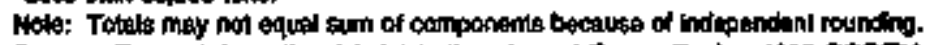

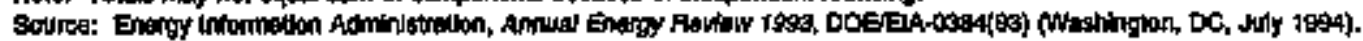


Table 46. U.S. Bituminous Coal Exports by Grade of Coal, 1975-1993 (Thousand Short Tons)

\begin{tabular}{|c|c|c|c|c|}
\hline & Yast & Matalluggleal & Steam & Tatal \\
\hline 1975 & $\ldots \ldots \ldots \ldots \ldots \ldots \ldots \ldots \ldots$ & 51,597 & 14,072 & 65,659 \\
\hline 1976 & $\ldots \ldots \ldots \ldots \ldots \ldots \ldots \ldots \ldots \ldots$ & 47,804 & 11,602 & 59,406 \\
\hline$\$ 977$ & $\ldots \ldots \ldots \ldots \ldots \ldots \ldots \ldots \ldots$ & 41, $\mathrm{Bg}$ & 11,796 & $53, \dot{B B 7}$ \\
\hline 1978 & $\ldots \ldots \ldots \ldots \ldots \ldots \ldots \ldots \ldots \ldots$ & 30.240 & 9.585 & 39,025 \\
\hline 1979 & $\ldots+\ldots \ldots \ldots \ldots \ldots \ldots+\ldots \ldots$ & 50,699 & 14,085 & $64,7 \mathrm{Bg}$ \\
\hline 1980 & $\ldots \ldots \ldots \ldots \ldots \ldots \ldots \ldots \ldots \ldots$ & 63,103 & 26,779 & 89,852 \\
\hline 1981 & $\ldots \ldots \ldots \ldots \ldots \ldots \ldots \ldots \ldots \ldots+\ldots$ & 65,284 & 45,010 & 110,243 \\
\hline 1982 & $\ldots \ldots \ldots \ldots \ldots \ldots \ldots \ldots$ & 64,585 & 40,659 & 105,244 \\
\hline 1983 & $\ldots \ldots \ldots \ldots \ldots \ldots \ldots \ldots \ldots \ldots \ldots$ & 49.964 & 26,905 & 76,870 \\
\hline 1984 & $\ldots \ldots \ldots \ldots \ldots \ldots \ldots \ldots \ldots$ & 56,975 & $29,8+8$ & 80,793 \\
\hline 1985 & $\ldots \ldots \ldots \ldots \ldots \ldots \ldots \ldots \ldots$ & 60,313 & 31,048 & 91,351 \\
\hline 1986 & $\ldots \ldots \ldots \ldots \ldots \ldots \ldots \ldots \ldots$ & 54,577 & 29,040 & 84,017 \\
\hline 1987 & $\ldots \ldots \ldots \ldots \ldots \ldots \ldots \ldots \ldots$ & $\$ 1,879$ & 26,713 & 78,392 \\
\hline 1988 & $\ldots \ldots \ldots \ldots \ldots \ldots \ldots \ldots$ & 61,950 & 32,057 & 94,007 \\
\hline 1989 & $\ldots \ldots \ldots \ldots \ldots \ldots \ldots \ldots \ldots$ & 65,128 & 34,910 & 100,003 \\
\hline 1980 & $\ldots \ldots \ldots \ldots \ldots \ldots \ldots \ldots \ldots$ & 63,459 & 41,578 & 105,097 \\
\hline 1991 & $\ldots \ldots \ldots \ldots \ldots \ldots \ldots \ldots \ldots$ & 64,652 & 48,852 & 108,494 \\
\hline 1982 & 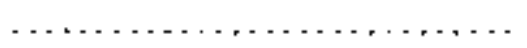 & 59.446 & 42,500 & t01,954 \\
\hline 1993 & $\ldots \ldots \ldots \ldots \ldots \ldots \ldots \ldots$ & 48,887 & 24,359 & 74,046 \\
\hline
\end{tabular}

Noles: Totale may not equal sum of components because of independent rounding.

Sources: U.S. Depertmem of Commerce, Bureeu of the Census, "Wonthly Report EM 5e2n (Washington, DC. 1974), and Nationed Coat Association, intemational Cog' Review Amwal 1994 (Washlingtor, DC, 1974). 
Table 47. U.s. Coal Produced for Export, by Origin and Destination, 1993 (Thousand Short Tons)

\begin{tabular}{|c|c|c|c|}
\hline \multirow{2}{*}{$\begin{array}{l}\text { Coal-Producing State and } \\
\text { Regton of Qrigin }\end{array}$} & \multicolumn{3}{|c|}{ Destination } \\
\hline & Caneada & Overseas" & Total \\
\hline Alabarna $\ldots \ldots \ldots \ldots+\ldots+\ldots+\ldots$ & $\mathbf{0}$ & 5,886 & 5,888 \\
\hline Alaskika $\ldots \ldots \ldots \ldots \ldots \ldots \ldots \ldots$ & 0 & 749 & 749 \\
\hline Coloreado $\ldots \ldots \ldots \ldots \ldots \ldots+\ldots \ldots$ & 0 & 1,128 & 1,128 \\
\hline Intols $\ldots \ldots \ldots \ldots \ldots \ldots \ldots \ldots \ldots$ & 0 & 670 & 670 \\
\hline Indiang $\ldots \ldots \ldots \ldots \ldots \ldots \ldots \ldots \ldots$ & 0 & 188 & 188 \\
\hline Kenturaky Total $\ldots \ldots+\ldots \ldots \ldots \ldots \ldots \ldots$ & 1,416 & 8,100 & 0,521 \\
\hline Easiem $\ldots \ldots \ldots \ldots \ldots \ldots \ldots \ldots$ & 1,416 & 7,902 & 9,310 \\
\hline Westerm $\ldots \ldots \ldots \ldots \ldots \ldots \ldots \ldots$ & 0 & 204 & 204 \\
\hline Marytand $\ldots \ldots \ldots \ldots \ldots \ldots \ldots \ldots$ & o & 295 & 295 \\
\hline Montang $\ldots \ldots \ldots \ldots \ldots \ldots \ldots \ldots$ & 54 & 67 & 121 \\
\hline Okdahoma $\ldots \ldots \ldots \ldots \ldots \ldots \ldots$ & o & 11 & 11 \\
\hline Pennsylwanta Tolal,$\ldots \ldots \ldots \ldots \ldots$ & 597 & 4,911 & 5.508 \\
\hline Anthractle $\ldots \ldots \ldots \ldots \ldots \ldots \ldots \ldots$ & 290 & 24 & 316 \\
\hline Btuminous $\ldots \ldots \ldots \ldots \ldots \ldots \ldots \ldots$ & 304 & 4,807 & 5.199 \\
\hline Utah $\ldots+\ldots \ldots+\ldots \ldots \ldots \ldots \ldots$ & 346 & 2,613 & $\mathbf{2 , 9 5 9}$ \\
\hline Virginila $\ldots \ldots \ldots \ldots \ldots \ldots \ldots \ldots \ldots$ & 1,228 & 13,021 & 14.251 \\
\hline Westinglon $\ldots \ldots \ldots \ldots \ldots \ldots \ldots+\ldots$ & 1 & Bg & 94 \\
\hline West Vưgink Totel . . . . . . . . . . . . & 4,108 & 29,052 & 33,159 \\
\hline Norhem $\ldots \ldots \ldots \ldots \ldots \ldots \ldots \ldots$ & 920 & 1,607 & 2,527 \\
\hline Southerm $\ldots \ldots \ldots+\cdots+\cdots+\ldots+\ldots$ & 3,187 & 27,445 & 30,652 \\
\hline Wyoming $\ldots \ldots \ldots \ldots \ldots \ldots \ldots \ldots$ & 0 & 974 & 974 \\
\hline Appetachlan fotal $\ldots \ldots \ldots \ldots \ldots \ldots \ldots$ & 7,350 & 61,069 & 68,419 \\
\hline tintelor Tatel $\ldots \ldots \ldots \ldots \ldots \ldots+\ldots \ldots$ & 0 & 1,073 & 1,073 \\
\hline Wertem Totak $\ldots \ldots \ldots \ldots \ldots \ldots \ldots$ & $\$ 01$ & 8,617 & 6,018 \\
\hline Eest of the Mlsalsalppit River . . . . . . . & 7,350 & 62,131 & 69,481 \\
\hline West of the Mississlpph Fiver $\ldots \ldots \ldots+\ldots$ & 401 & 5,628 & 6,030 \\
\hline U.s. Total $\ldots \ldots \ldots \ldots \ldots \ldots \ldots \ldots \ldots \ldots$ & 7,751 & 67,759 & 75,510 \\
\hline
\end{tabular}

AAso includes Mexteo.

Note: Tolals may not exual bum of components because of independent counding. Source: Energy intormaliton Adrnintstration, Form ElA-6, "Coof Disinibution Report." 
Figure 35. U.S. Cosl Exports, 1970-1993

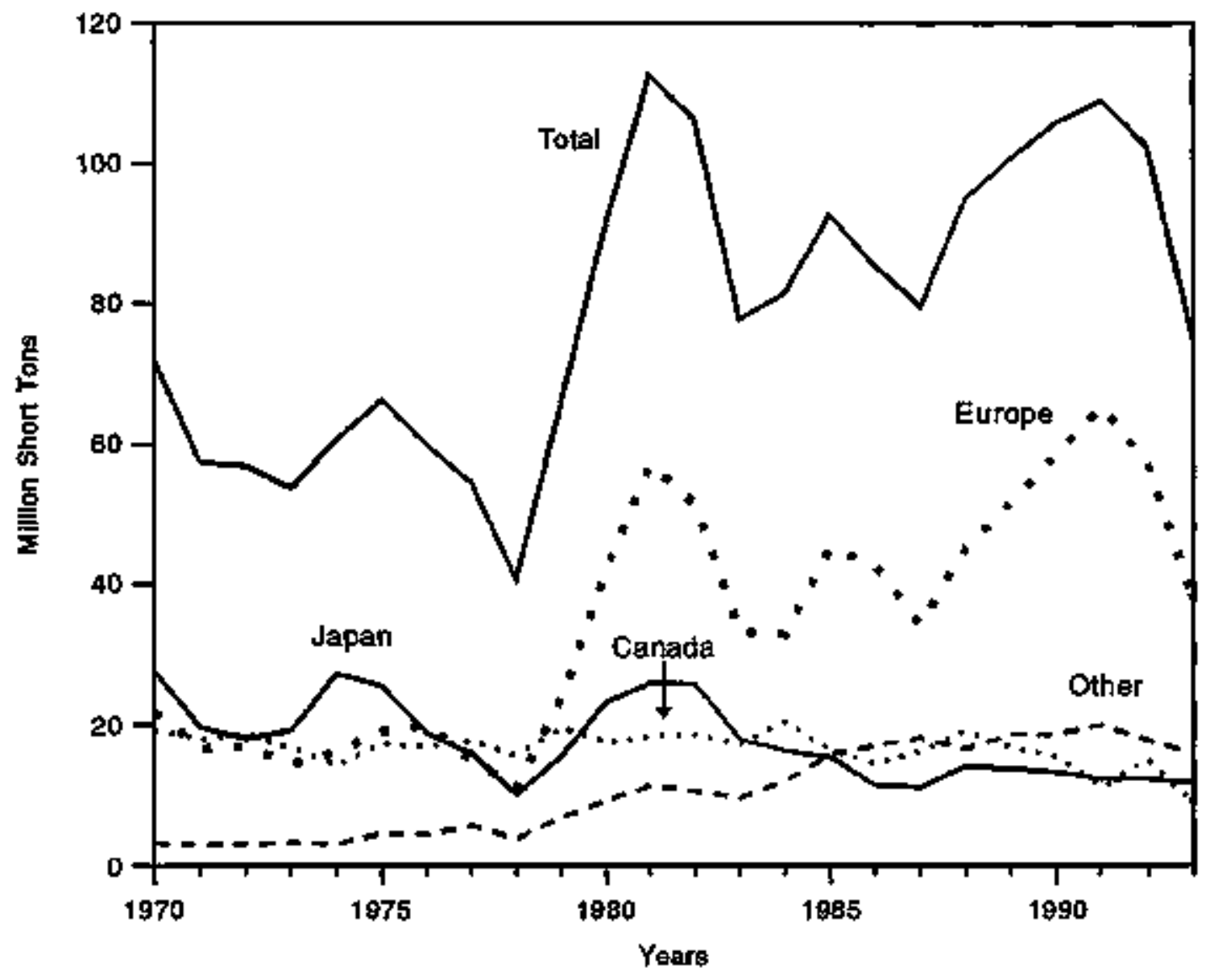

Source: Energy Information Actrinistration, Annuel Energy Reviow 1989, DOEJELA-0984(93) Washington, DC, Juty 1994). 
Figura 36. World Coal Production and Leading CoakProducing Countries, 1880-1992

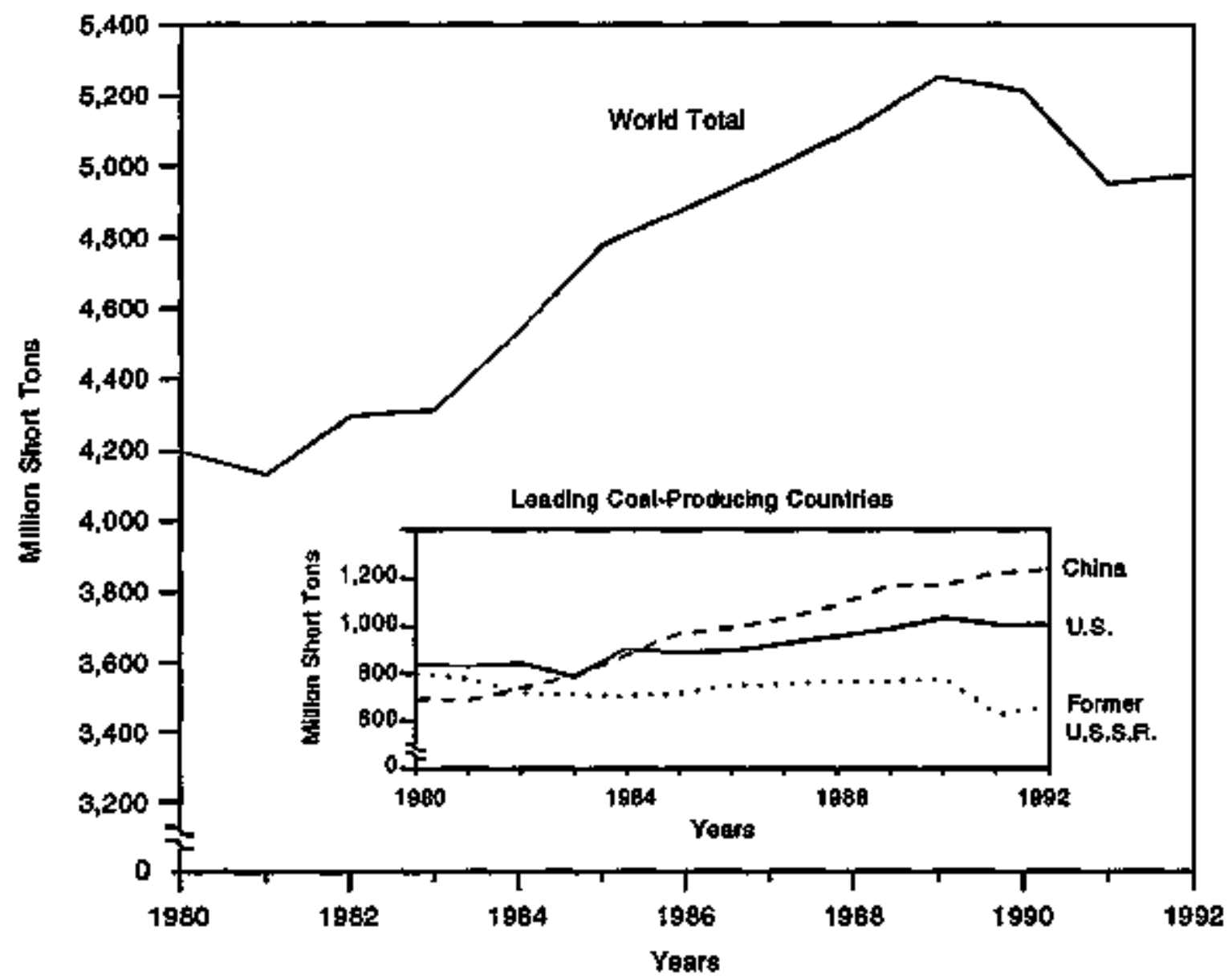

Wand cod production rose fram about 4.2 billfon tons in 1980 to a racord 5.3 bithon tons in 1989 and was about 5.0 billien fons in 1992. The Uniled States is a major coll proderear, it ranked first from 1980 through 1982 and again in 1984.

Note: Casl production in 1992 from counkties thet composed the former U.S.S.A. wes follows, in malion short tons: Kazakhaten, 139; Russia, 372; Ukrains, 148.

Source: Energy Information Admin|stration, Intemsilionat Enargy Amtial 1982, DOEElA-O219(92) (Washinglon, DC, January 1994). 
Figure 37. Average Quallty of Coal Produced for Power Plants by Producing State, 1993

Heat $v$ alue

(MM blu per short ton)

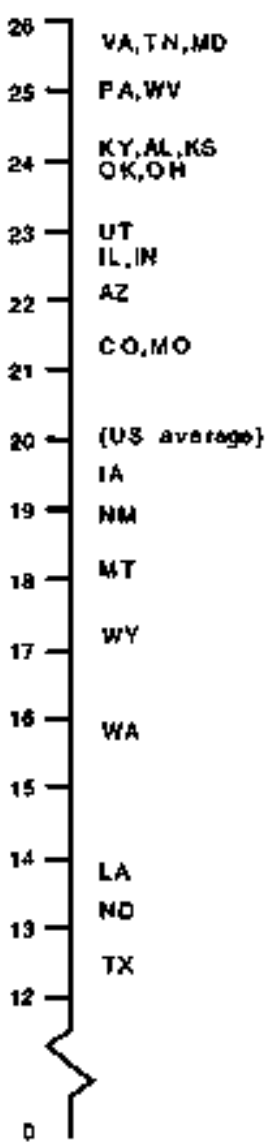

Sulfur Con tent (average weight perceni)

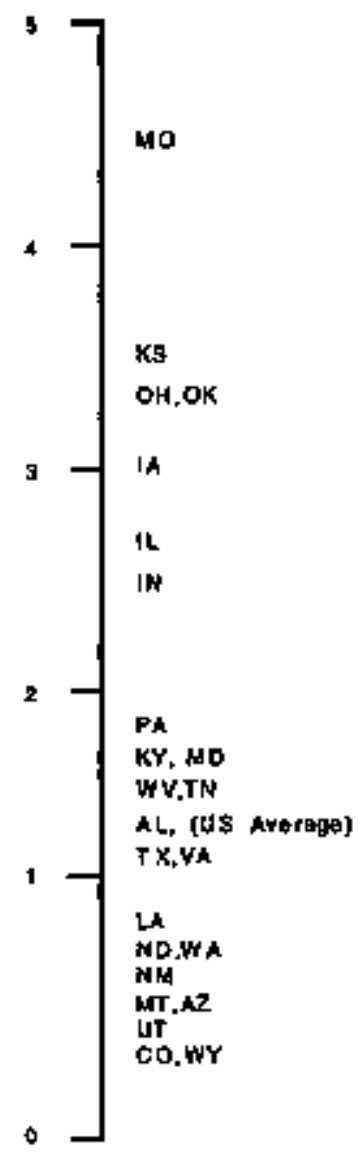

Sulfur (pounds par hot etu)

5

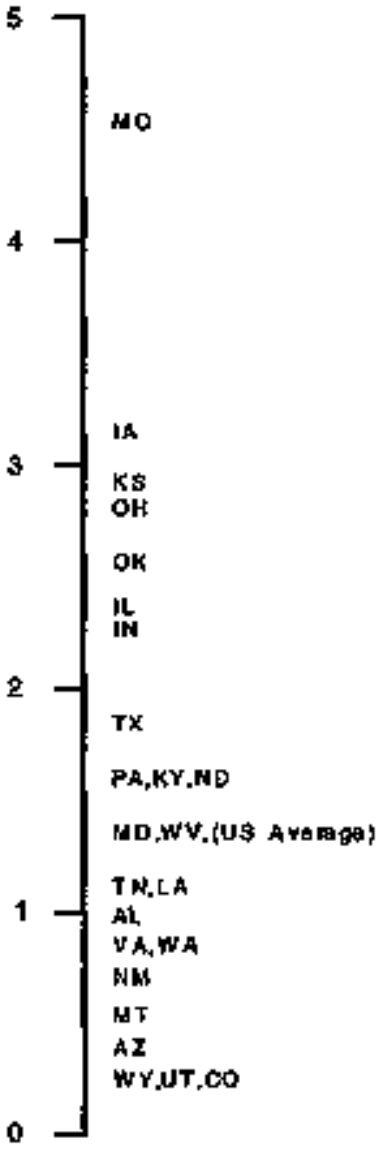

A sh Conlent (average wajght percenl)

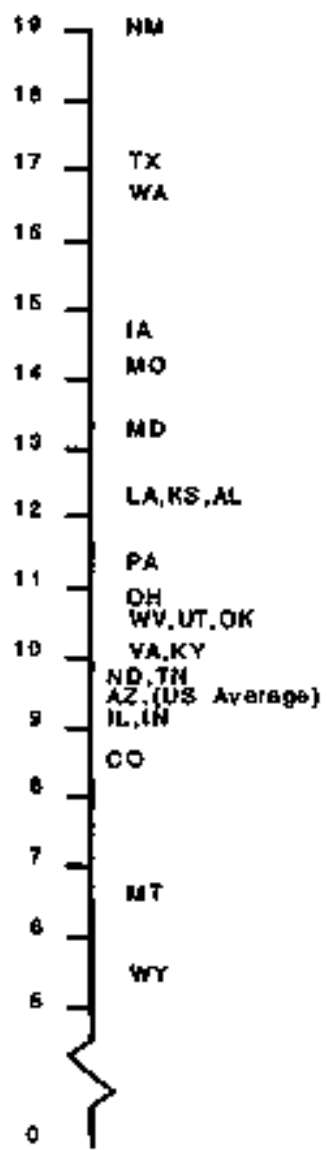

Note: MMEłu = million British thermal units.

Source: Ensrgy Information Administration, Cost and Qually of Fuels for Electric Ublity Plants 1993, DOEJElA+0191(93) (Washington, DC, July 1994). 
Figure 38. Cost and Quality of Coal Shlpped to Electric Utititles, by Origin, 1993

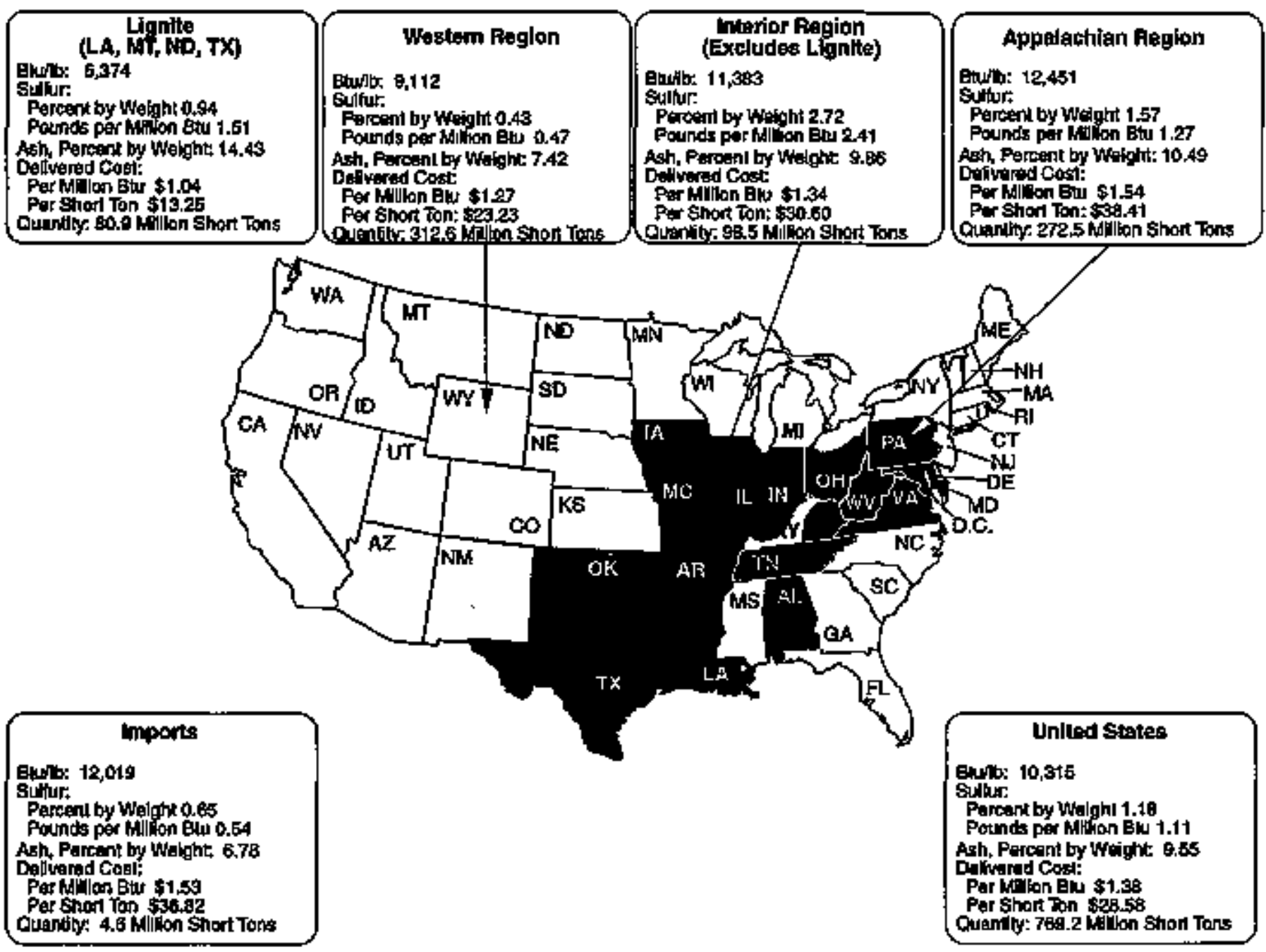

Cost was mined in 26 Slates in 1993.

Source: Energy Informetion Administration, Cost and Qualty of Fuals for Electic Untity Plants I9283, DOEJEIA-019(93) (Washington, DC, July 1994). 
Table 48. U.S. Air Pollutant Emission Estimates from Coal Combustion as Compared with Total Emissions and Total Coal Consumption, Sedected Years, 1970, 1980, 1990-1992

(Million Shot Tone)

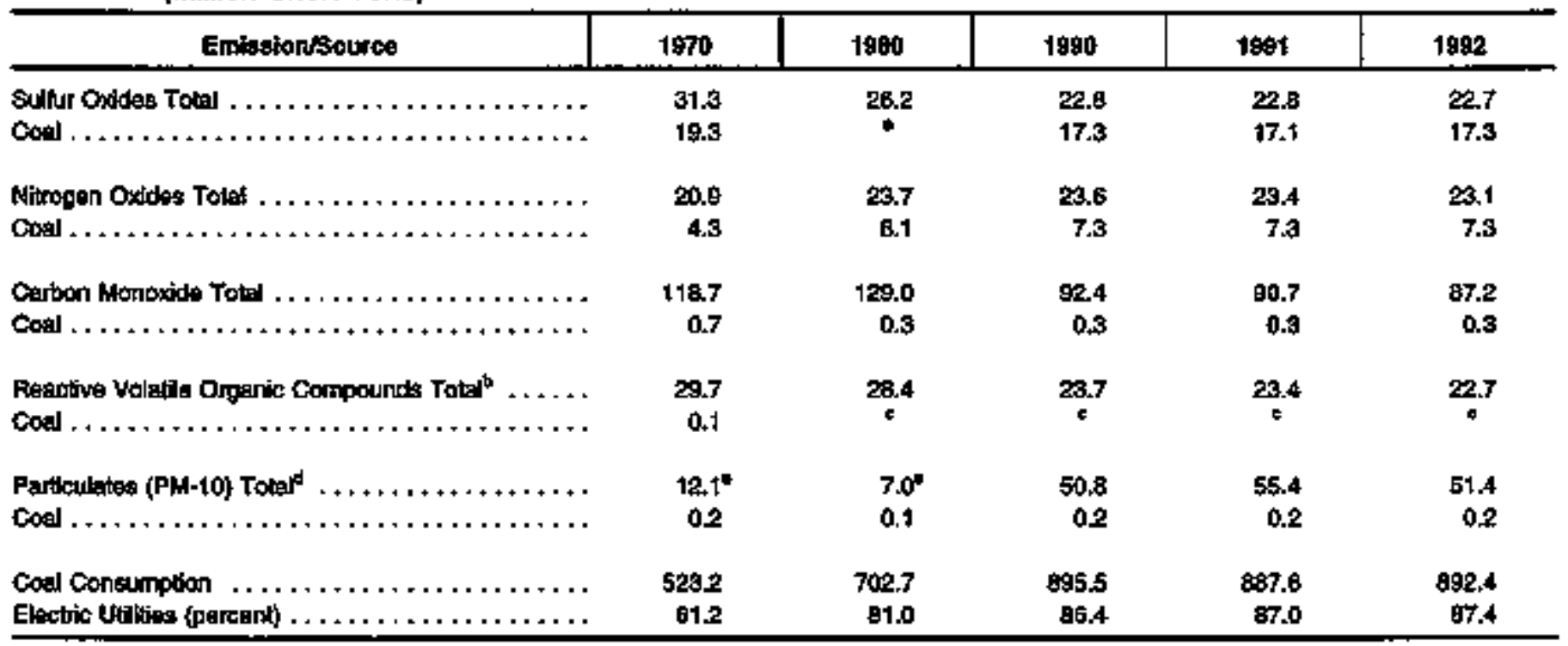

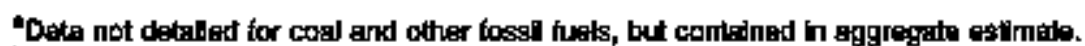

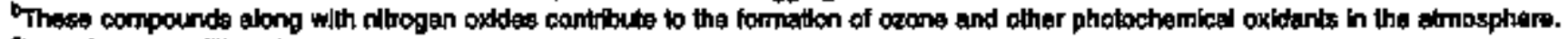

Less then .05 million ohort tons.

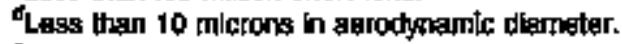

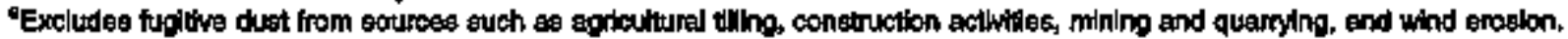

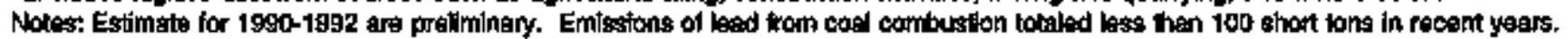

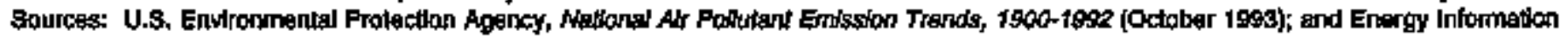
Adminlatration, Amusi Enargy Rewisw 1993, DOEEAA-0384(93) (Weabinglon, DC, dity 1994). 
Table 49. U.S. Utalty Coal Combustlon Byproducts: Production and Use, 1992 (Mifluon Short Tons)

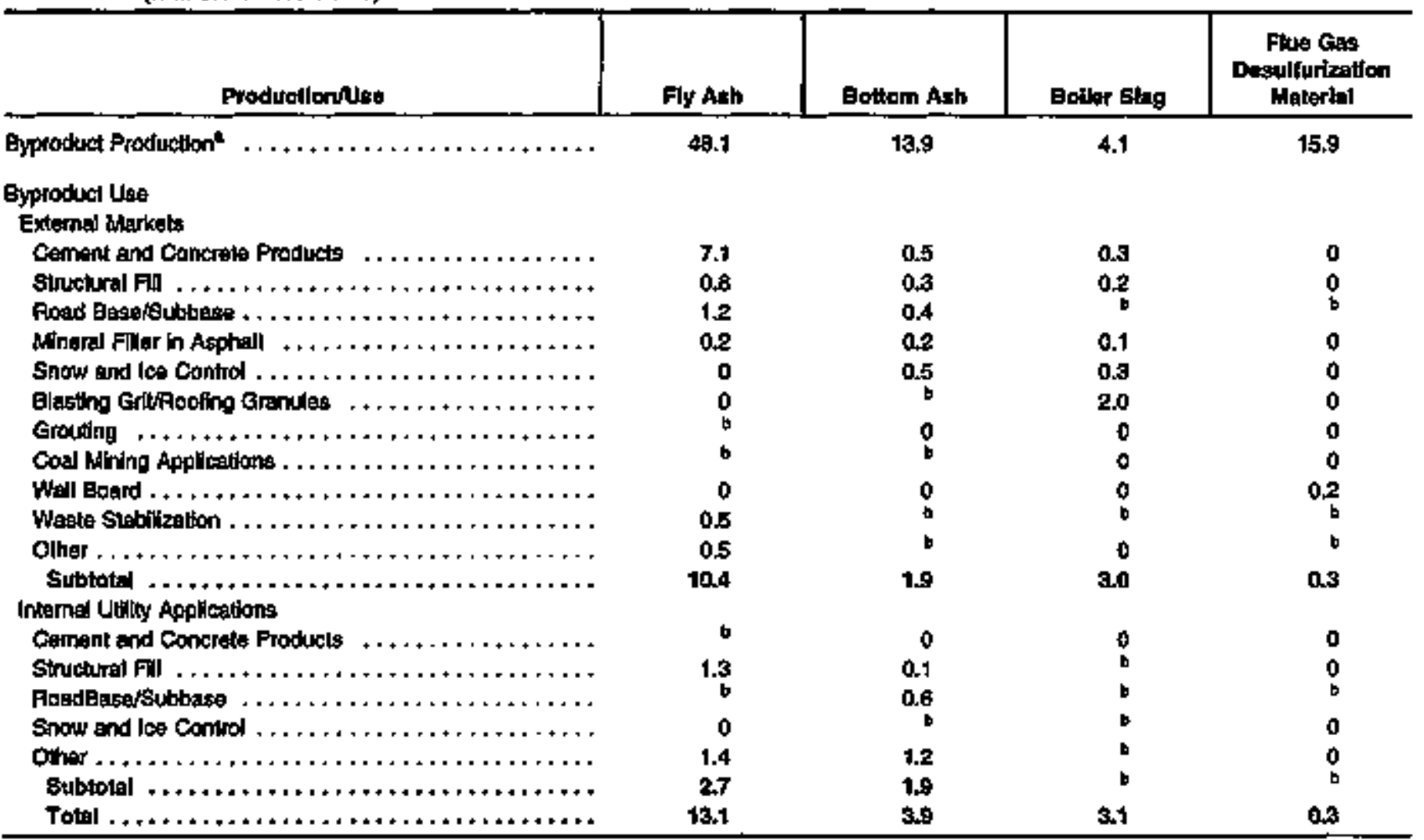

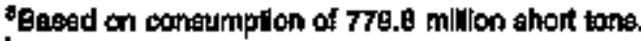

biss than 100,000 splyor toris.

Note: Tola's may not equal sum of companents because of Independent rounding.

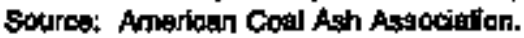


Table 50. Trace Elements in U.S. Coal: Hlghest Average Concentration by Rank and Widest Range by Region and Rank of Coal

\begin{tabular}{|c|c|c|c|c|c|}
\hline \multirow[b]{2}{*}{ Trace Element } & \multirow[b]{2}{*}{$\begin{array}{l}\text { Chamlcal } \\
\text { Symbol }\end{array}$} & \multicolumn{2}{|c|}{ Highest Average } & \multicolumn{2}{|r|}{ Widest Range } \\
\hline & & $\begin{array}{l}\text { Averaga } \\
\text { (parts get } \\
\text { million) }\end{array}$ & Coal Rank & $\begin{array}{l}\text { Armount } \\
\text { (pistis per } \\
\text { m|'lion) }\end{array}$ & Rieglon and Coal Ranik \\
\hline Antimony $\ldots \ldots \ldots \ldots \ldots \ldots \ldots$ & Sb & 1.2 & Bituminous & $0.04-43$ & Rocky Mountain subbltumindus \\
\hline Assanic $\ldots \ldots \ldots+\ldots \ldots \ldots+$ & As & $2 \beta$ & Ugnitte & $0.2-420$ & Northera Pleins subblturninous: \\
\hline Beylinam $\ldots \ldots \ldots \ldots \ldots \ldots$ & $\mathrm{Be}$ & 22 & Bituminous & $0.00-32$ & Rocky Moumlain subbituminots \\
\hline Cachinim $\ldots \ldots \ldots \ldots \ldots \ldots$ & Cd. & 0.9 & Bthuminous & $0.01-170$ & Interior bltuminous \\
\hline Chkorine $\ldots \ldots \ldots \ldots \ldots \ldots \ldots$ & $\mathbf{a}$ & NA & NA & $50-8,000$ & Appalachlan bhum|nous \\
\hline Chromium $\ldots \ldots \ldots \ldots \ldots \ldots$ & $G$ & 47 & Anthracite & $1.5-220$ & Appalechian bltuminous \\
\hline Cobalt $\ldots \ldots \ldots \ldots \ldots \ldots \ldots \ldots$ & Co & 9.7 & Btuminous & 0.72960 & Appalachian bituminous \\
\hline Fuporine $\ldots+\ldots \ldots+\ldots+\ldots+\ldots$ & $\mathbf{F}$ & 191 & Ugnite & $20-1,000$ & Appalactian bltuminous \\
\hline Laed $\ldots \ldots \ldots \ldots \ldots \ldots \ldots \ldots$ & $\mathbf{P b}$ & 14 & Blatminous & $0.79 \cdot 590$ & Interior bhuminows \\
\hline Manganesg $\ldots \ldots \ldots \ldots \ldots \ldots$ & Mn & 300 & Lignilte & $1.4-9.500$ & Packy Mountein subbituminous \\
\hline Maraury $\ldots \ldots \ldots \ldots+\ldots+\ldots+$ & $\mathbf{H g}$ & 0.23 & Anthractio & $0.01-12$ & Northem Fains linnite \\
\hline Nicket $\ldots \ldots \ldots \ldots \ldots \ldots \ldots$ & $\mathbf{N}$ & 28 & Anlinracite & $0.87-580$ & Interior bituminous \\
\hline Phosphonus .............. & $\mathbf{P}$ & 1,900 & LFg̣nlte & $<4-6,000$ & Appalachian btuminous \\
\hline Selenium $\ldots \ldots \ldots \ldots \ldots \ldots \ldots$ & Se & 3.4 & Blituminous & $0.12 \cdot 150$ & Appalachian blhiminous \\
\hline Thorium $\ldots \ldots \ldots \ldots \ldots \ldots \ldots$ & Th & 7.1 & Lignile & $0.04-79$ & Interior biluminous \\
\hline Uraninm $+\ldots \ldots \ldots \ldots+\ldots \ldots \ldots$ & $\mathbf{U}$ & 3.4 & Lignite & $0.06-76$ & Packy Mountain sabbltuminous \\
\hline
\end{tabular}

"Elements identitied as hazardous air pollutants by the Cloen Air Act, as amended in 1990.

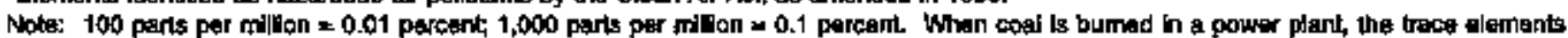
are concentraied es follows: in fly ash-Sb, As, Be, Cd, Cr, M, Ft, and Sa; in both fly ash and bottom ash-Co, Mn, Th, U, and probabły P; as a rapor-Cl, $\mathrm{F}$, and $\mathrm{Hg}$.

NA = Not evellable.

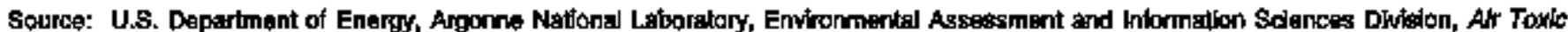

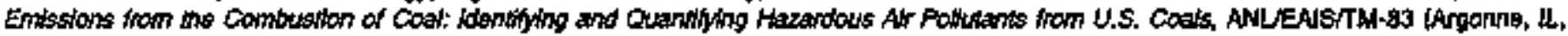
Septamber 1992). 
Table 51. Classiffication of Coals by Rank

\begin{tabular}{|c|c|c|c|c|}
\hline Coal Fank & Coal Group & \multicolumn{3}{|c|}{ Bagts of Classifioation } \\
\hline \multirow{2}{*}{\multicolumn{2}{|c|}{ Coald Clasidified by Fixed Cabon }} & \multicolumn{2}{|c|}{ FIxid Garton Percentages } & \multirow[b]{2}{*}{ Agglomerating Character } \\
\hline & & $\begin{array}{l}\text { Equal to or } \\
\text { Greater than }\end{array}$ & Lese then & \\
\hline 14. Elhaminous: & 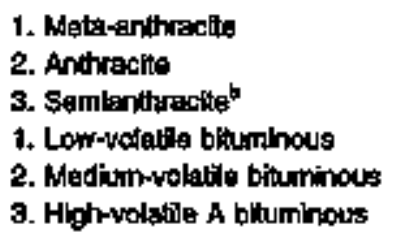 & $\begin{array}{r}90 \\
92 \\
80 \\
78 \\
69 \\
-\end{array}$ & $\begin{array}{r}- \\
98 \\
92 \\
86 \\
78 \\
69\end{array}$ & \multirow[t]{3}{*}{ 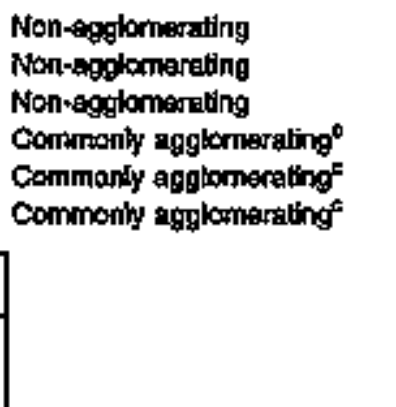 } \\
\hline & & \multicolumn{2}{|c|}{ Hoat content in Btu per Pound } & \\
\hline \multicolumn{2}{|c|}{ Coald clesulified by Heat tontent } & $\begin{array}{c}\text { Equal } 10 \text { or Grealer } \\
\text { then }\end{array}$ & Lass than & \\
\hline It. Bluminous & $\begin{array}{l}\text { 4. High-volabile B bltuminous } \\
\text { 5. High-valatife C blturninous } \\
\text { 6. High-wolatile C biluminous }\end{array}$ & $\begin{array}{l}13,000 \\
11,500 \\
10,500\end{array}$ & $\begin{array}{l}14,000 \\
13,000 \\
11,500\end{array}$ & $\begin{array}{l}\text { Commonly agglomaralingo } \\
\text { Commonly agolomeradng" } \\
\text { agglomextling }\end{array}$ \\
\hline it. Stbtikumtrous & $\begin{array}{l}\text { 1. Subbituminous A } \\
\text { 2. subblimininous B }\end{array}$ & $\begin{array}{r}10,500 \\
9,500\end{array}$ & $\begin{array}{l}11,500 \\
t 0,500\end{array}$ & $\begin{array}{l}\text { Non-aggiomeraing } \\
\text { Non-ggfomeraing }\end{array}$ \\
\hline & 3. Subbituminous C & $B, 300$ & 9,500 & Non-agylomerating \\
\hline N. Lorille & $\begin{array}{l}\text { 1. Lignile A } \\
\text { 2. Lgntic B }\end{array}$ & 6,300 & $\begin{array}{l}8,300 \\
6,300\end{array}$ & $\begin{array}{l}\text { Non-aggiondrating } \\
\text { Non-ggglom datiog }\end{array}$ \\
\hline
\end{tabular}

Parcenkages are besed on dnerninaralmatlerthee cost. Volalle malter (not shown) is the comptement of tixed cartorr, that is, the

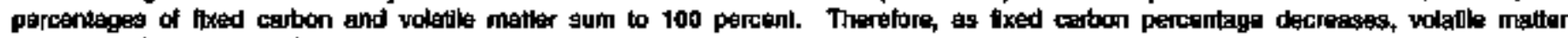
percentage increases by the som ambunt.

II agglomeraing, classily in tow-volatile group of the bluninous cless.

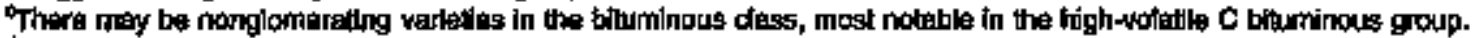

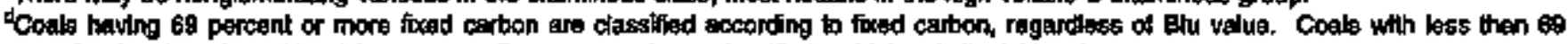

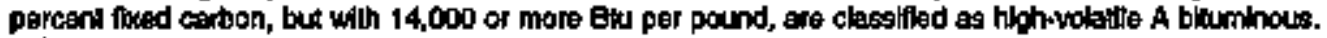

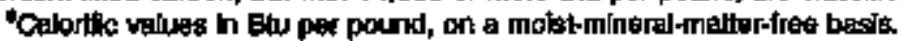

Note; Terms in this table ang defined in the Glosisiny.

Source: Adepled from Ameriean Society for Testing and Waterials 1989, Standard Classileation of Coel by Renk, A6TM Designetion D388BA.

Table 52. Approximate Weights of Unbroken (Solid) Coal in the Ground

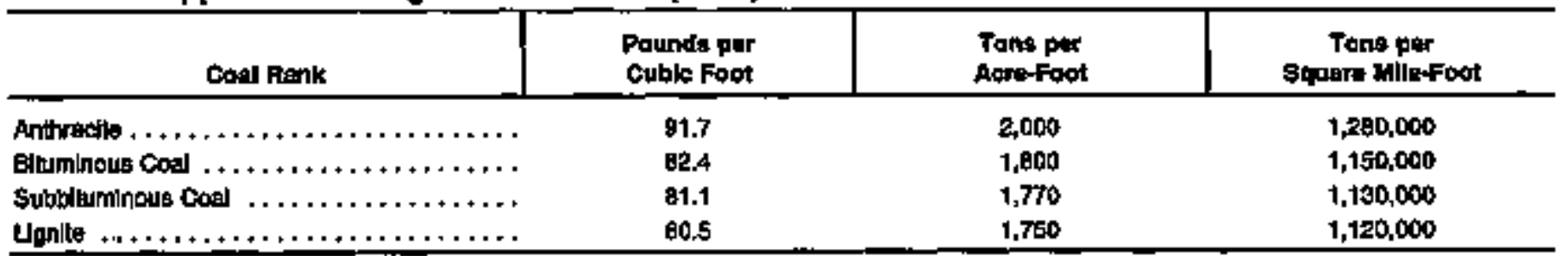

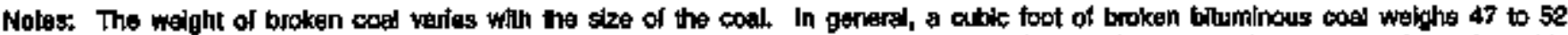

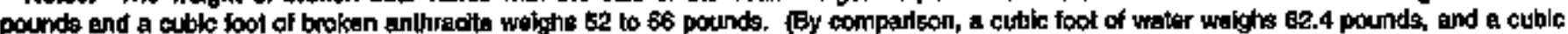

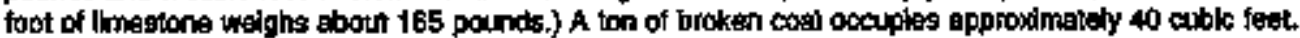

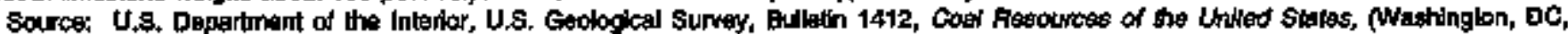
1975 . 
Table 53. Fepresentathe Analyses of U.S. Coat

\begin{tabular}{|c|c|c|c|c|c|c|c|c|c|c|c|c|c|}
\hline \multirow[b]{2}{*}{$\begin{array}{c}\text { Clasentication by } \\
\text { Rynk }\end{array}$} & \multirow[b]{2}{*}{ Stotorcicunty } & \multirow[b]{2}{*}{ Bed } & \multirow[b]{2}{*}{$\begin{array}{c}\text { Typa } \\
\text { samaple }\end{array}$} & \multicolumn{4}{|c|}{ Proxtante Purtent } & \multicolumn{5}{|c|}{ Litimate Percant } & \multirow{2}{*}{$\begin{array}{l}\text { Calorifis } \\
\text { Valuse, } \\
\text { Btu par } \\
\text { polind }\end{array}$} \\
\hline & & & & Moistura & $\begin{array}{l}\text { Volatile } \\
\text { Matter }\end{array}$ & Fartorn & Ash & Sur & $\begin{array}{l}\text { Hydro- } \\
\text { gen }\end{array}$ & $\begin{array}{l}\text { Car- } \\
\text { bon }\end{array}$ & $\begin{array}{l}\text { Nitro- } \\
\text { gen }\end{array}$ & $\begin{array}{l}\text { Oxy- } \\
g \in n\end{array}$ & \\
\hline Meta-enthracite .. & $\begin{array}{l}\text { Phodd Isdand } \\
\text { Nowport }\end{array}$ & Meddle & $\begin{array}{l}1 \\
2 \\
3\end{array}$ & $\begin{array}{l}13.2 \\
- \\
=\end{array}$ & $\begin{array}{l}2.6 \\
2.9 \\
3.8\end{array}$ & $\begin{array}{l}65.3 \\
75.3 \\
96.2\end{array}$ & $\begin{array}{c}18.9 \\
21.6 \\
-\end{array}$ & $\begin{array}{l}0.3 \\
0.3 \\
0.4\end{array}$ & $\begin{array}{l}1.8 \\
0.5 \\
0.6\end{array}$ & $\begin{array}{l}64.2 \\
74.1 \\
94.7\end{array}$ & $\begin{array}{l}0.2 \\
0.2 \\
0.3\end{array}$ & $\begin{array}{r}14.5 \\
3.1 \\
4.0\end{array}$ & $\begin{array}{r}9,310 \\
10,740 \\
13,720\end{array}$ \\
\hline Anlhracte $\ldots \ldots$ & $\begin{array}{l}\text { Pennsylwaria } \\
\text { Lackrowana }\end{array}$ & Clexk & $\begin{array}{l}1 \\
2 \\
3\end{array}$ & $\begin{array}{l}4.3 \\
- \\
-\end{array}$ & $\begin{array}{l}5.1 \\
5.3 \\
5.9\end{array}$ & $\begin{array}{l}81.0 \\
84.6 \\
94.1\end{array}$ & $\begin{array}{r}9.6 \\
10.1 \\
-\end{array}$ & $\begin{array}{l}0.8 \\
0.8 \\
0.9\end{array}$ & $\begin{array}{l}2.9 \\
2.5 \\
2.8\end{array}$ & $\begin{array}{l}79.7 \\
83.3 \\
92.5\end{array}$ & $\begin{array}{l}0.9 \\
0.9 \\
1.0\end{array}$ & $\begin{array}{l}6.1 \\
2.4 \\
2.0\end{array}$ & $\begin{array}{l}12,880 \\
13,470 \\
14,980\end{array}$ \\
\hline Semlanthractlo ... & $\begin{array}{l}\text { Arkeneses } \\
\text { Johnson }\end{array}$ & $\begin{array}{l}\text { Lower } \\
\text { Harlsheme }\end{array}$ & $\begin{array}{l}1 \\
2 \\
3\end{array}$ & $\begin{array}{l}2.6 \\
- \\
*\end{array}$ & $\begin{array}{l}10.6 \\
10.8 \\
11.7\end{array}$ & $\begin{array}{l}74.3 \\
84.5 \\
88.3\end{array}$ & $\begin{array}{l}7.6 \\
7.7 \\
-\end{array}$ & $\begin{array}{l}1.7 \\
1.8 \\
1.9\end{array}$ & $\begin{array}{l}3.8 \\
3.6 \\
3.9\end{array}$ & $\begin{array}{l}81.4 \\
63.6 \\
90.6\end{array}$ & $\begin{array}{l}1.6 \\
1.6 \\
1.5\end{array}$ & $\begin{array}{l}4.0 \\
1.7 \\
1.0\end{array}$ & $\begin{array}{l}13,890 \\
14,240 \\
15,430\end{array}$ \\
\hline $\begin{array}{l}\text { Low } \\
\text { Bituminolaling }\end{array}$ & $\begin{array}{l}\text { West Virginia } \\
\text { Wyoming }\end{array}$ & $\begin{array}{l}\text { Pocthonlas } \\
\text { No. } 3\end{array}$ & $\begin{array}{l}1 \\
2 \\
3\end{array}$ & $\begin{array}{l}2.6 \\
- \\
-\end{array}$ & $\begin{array}{l}17.7 \\
16.2 \\
19.3\end{array}$ & $\begin{array}{l}74.0 \\
76.3 \\
80.7\end{array}$ & $\begin{array}{l}6.4 \\
5.5 \\
-\end{array}$ & $\begin{array}{l}0.8 \\
0.8 \\
0.8\end{array}$ & $\begin{array}{l}4.6 \\
4.4 \\
4.6\end{array}$ & $\begin{array}{l}83.2 \\
85.7 \\
90.7\end{array}$ & $\begin{array}{l}1.3 \\
1.3 \\
1.4\end{array}$ & $\begin{array}{l}4.7 \\
2.3 \\
2.5\end{array}$ & $\begin{array}{l}14,400 \\
14,830 \\
16,690\end{array}$ \\
\hline $\begin{array}{l}\text { Mexilum-4folatila } \\
\text { Bituninous Coal }\end{array}$ & $\begin{array}{l}\text { Pennsybuania } \\
\text { Creatiold }\end{array}$ & $\begin{array}{l}\text { Upper } \\
\text { Kiltanning }\end{array}$ & $\begin{array}{l}1 \\
2 \\
3\end{array}$ & $\begin{array}{l}21 \\
- \\
-\end{array}$ & $\begin{array}{l}24.4 \\
24.9 \\
26.5\end{array}$ & $\begin{array}{l}67.4 \\
69.5 \\
79.5\end{array}$ & $\begin{array}{l}6.1 \\
6.3 \\
-\end{array}$ & $\begin{array}{l}1.0 \\
1.1 \\
1.1\end{array}$ & $\begin{array}{l}5.0 \\
4.8 \\
5.2\end{array}$ & $\begin{array}{l}81.6 \\
83.3 \\
88.9\end{array}$ & $\begin{array}{l}1.4 \\
1.5 \\
1,6\end{array}$ & $\begin{array}{l}4.9 \\
3.0 \\
3.2\end{array}$ & $\begin{array}{l}14,310 \\
14,610 \\
15,590\end{array}$ \\
\hline $\begin{array}{l}\text { High-watatile A } \\
\text { Bihmininous Cost }\end{array}$ & $\begin{array}{l}\text { West Virginla } \\
\text { Marian }\end{array}$ & Pittebulyh & $\begin{array}{l}1 \\
2 \\
3\end{array}$ & $\begin{array}{l}2.3 \\
- \\
-\end{array}$ & $\begin{array}{l}36.5 \\
37.4 \\
39.5\end{array}$ & $\begin{array}{l}56.5 \\
57.2 \\
60.5\end{array}$ & $\begin{array}{l}5.2 \\
6.4 \\
-\end{array}$ & $\begin{array}{l}0.8 \\
0.8 \\
0.8\end{array}$ & $\begin{array}{l}5.5 \\
5.4 \\
5.7\end{array}$ & $\begin{array}{l}79.4 \\
80.2 \\
84.8\end{array}$ & $\begin{array}{l}1.5 \\
1.6 \\
1.7\end{array}$ & $\begin{array}{l}8.5 \\
6.6 \\
7.0\end{array}$ & $\begin{array}{l}14,040 \\
14,370 \\
15,180\end{array}$ \\
\hline $\begin{array}{l}\text { Hggh-rotabile B } \\
\text { Elluminous Coal }\end{array}$ & $\begin{array}{l}\text { Kenturedy } \\
\text { (Wostem field) } \\
\text { Mulderburg }\end{array}$ & No. 9 & $\begin{array}{l}1 \\
2 \\
3\end{array}$ & $\begin{array}{l}8.6 \\
- \\
-\end{array}$ & $\begin{array}{l}36.4 \\
39.8 \\
45.0\end{array}$ & $\begin{array}{l}44.3 \\
48.5 \\
55.0\end{array}$ & $\begin{array}{c}10.8 \\
11.7 \\
-\end{array}$ & $\begin{array}{l}28 \\
3.0 \\
3.4\end{array}$ & $\begin{array}{l}5.4 \\
4.9 \\
5.5\end{array}$ & $\begin{array}{l}65.1 \\
71.2 \\
80.6\end{array}$ & $\begin{array}{l}1.3 \\
1.5 \\
1.7\end{array}$ & $\begin{array}{r}14.6 \\
7.7 \\
8.8\end{array}$ & $\begin{array}{l}11,680 \\
12,760 \\
14,480\end{array}$ \\
\hline $\begin{array}{l}\text { H'gh-vodelila C } \\
\text { Bihuminutus Cots }\end{array}$ & $\begin{array}{l}\text { Inlnois } \\
\text { Sangamon }\end{array}$ & No. 5 & $\begin{array}{l}1 \\
2 \\
3\end{array}$ & $\begin{array}{l}14.4 \\
- \\
-\end{array}$ & $\begin{array}{l}35.4 \\
41.4 \\
46.6\end{array}$ & $\begin{array}{l}40.6 \\
47.4 \\
59.4\end{array}$ & $\begin{array}{r}9.6 \\
11.2 \\
-\end{array}$ & $\begin{array}{l}3.8 \\
4.4 \\
5.0\end{array}$ & $\begin{array}{l}5.8 \\
4.9 \\
5.6\end{array}$ & $\begin{array}{l}59.7 \\
69.8 \\
78.6\end{array}$ & $\begin{array}{l}1.0 \\
1.2 \\
1.3\end{array}$ & $\begin{array}{r}20.1 \\
8.5 \\
9.5\end{array}$ & $\begin{array}{l}10,610 \\
12,640 \\
14,250\end{array}$ \\
\hline $\begin{array}{l}\text { Subbhtuminous A } \\
\text { Coal } \ldots \ldots \ldots \ldots\end{array}$ & $\begin{array}{l}\text { Wyoming } \\
\text { Swastwaler }\end{array}$ & No. 3 & $\begin{array}{l}1 \\
2 \\
3\end{array}$ & $\begin{array}{l}16.9 \\
- \\
-\end{array}$ & $\begin{array}{l}34.8 \\
41.8 \\
43.7\end{array}$ & $\begin{array}{l}44.7 \\
53.8 \\
56.9\end{array}$ & $\begin{array}{l}3.6 \\
4.4 \\
-\end{array}$ & $\begin{array}{l}1.4 \\
1.7 \\
1.8\end{array}$ & $\begin{array}{l}6.0 \\
4.9 \\
5.2\end{array}$ & $\begin{array}{l}60.4 \\
72.7 \\
76.0\end{array}$ & $\begin{array}{l}1.2 \\
1.5 \\
1.5\end{array}$ & $\begin{array}{l}27.4 \\
14.8 \\
16.6\end{array}$ & $\begin{array}{l}10,650 \\
18,810 \\
13,050\end{array}$ \\
\hline $\begin{array}{l}\text { Subbiturincus B } \\
\text { Coal } \ldots \ldots \ldots\end{array}$ & $\begin{array}{l}\text { Wyoming } \\
\text { Shoriden }\end{array}$ & Monanch & $\begin{array}{l}1 \\
2 \\
3\end{array}$ & $\begin{array}{l}822 \\
- \\
-\end{array}$ & $\begin{array}{l}33.2 \\
42.7 \\
45.2\end{array}$ & $\begin{array}{l}40.3 \\
51.7 \\
54.8\end{array}$ & $\begin{array}{l}4.9 \\
8.6 \\
-\end{array}$ & $\begin{array}{l}0.5 \\
0.6 \\
0.6\end{array}$ & $\begin{array}{l}6.9 \\
5.6 \\
6.0\end{array}$ & $\begin{array}{l}59.9 \\
69.3 \\
73.4\end{array}$ & $\begin{array}{l}1.0 \\
1.2 \\
1.3\end{array}$ & $\begin{array}{l}38.4 \\
17.7 \\
18.7\end{array}$ & $\begin{array}{r}9,610 \\
12,350 \\
13,080\end{array}$ \\
\hline $\begin{array}{l}\text { Subbítuminous c } \\
\text { Cosd .......... }\end{array}$ & $\begin{array}{l}\text { Whoming } \\
\text { Compbell }\end{array}$ & Wyodak & $\begin{array}{l}1 \\
2 \\
3\end{array}$ & $\begin{array}{l}25.6 \\
+ \\
-\end{array}$ & $\begin{array}{l}33.2 \\
452 \\
49.1\end{array}$ & $\begin{array}{l}34.4 \\
46.9 \\
50.9\end{array}$ & $\begin{array}{l}5.8 \\
7.9 \\
-\end{array}$ & $\begin{array}{l}0.6 \\
0.8 \\
0.9\end{array}$ & $\begin{array}{l}5.5 \\
4.8 \\
5.0\end{array}$ & $\begin{array}{l}50.0 \\
67.6 \\
75.3\end{array}$ & $\begin{array}{l}0.9 \\
1.2 \\
1.3\end{array}$ & $\begin{array}{l}36.2 \\
17.7 \\
19.5\end{array}$ & $\begin{array}{r}8,650 \\
11,760 \\
12,780\end{array}$ \\
\hline Ltgnile $\ldots \ldots \ldots$ & $\begin{array}{l}\text { North Dekola } \\
\text { Mctean }\end{array}$ & Unnemed & $\begin{array}{l}1 \\
2 \\
3\end{array}$ & $\begin{array}{l}38.8 \\
= \\
-\end{array}$ & $\begin{array}{l}27.8 \\
43.9 \\
46.4\end{array}$ & $\begin{array}{l}29.5 \\
48.7 \\
51.6\end{array}$ & $\begin{array}{l}5.9 \\
8.4 \\
-\end{array}$ & $\begin{array}{l}0.9 \\
1.4 \\
1.6\end{array}$ & $\begin{array}{l}6.9 \\
4.5 \\
5.0\end{array}$ & $\begin{array}{l}40.6 \\
64.3 \\
70.9\end{array}$ & $\begin{array}{l}0.6 \\
1.0 \\
1.1\end{array}$ & $\begin{array}{l}45.1 \\
19.4 \\
21.4\end{array}$ & $\begin{array}{r}7,000 \\
11,090 \\
12,290\end{array}$ \\
\hline
\end{tabular}

1. Sample as received 2. Mobationires 3. Wolshure and ash-frae.

- - Not applicable.

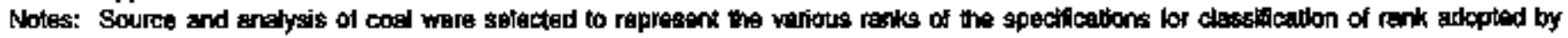
the Amarican Sockleby for Tosting and materlats.

Sourea: US. Department of the Interlor, Burealy of Mines; and Wyoming State Geabogited Survery (Whodak bed). 
Teble 54. Standerd Anthracito Specifications

\begin{tabular}{|c|c|c|c|c|c|c|}
\hline \multirow[b]{2}{*}{ Sitate } & \multirow{2}{*}{$\begin{array}{l}\text { Strite Round Test Iteash } \\
\text { (Inches) }\end{array}$} & \multicolumn{5}{|c|}{ Percent } \\
\hline & & Maximum & Minimum & State & Bone & $A \operatorname{sen}^{6}$ \\
\hline Broken $\ldots \ldots \ldots \ldots \ldots \ldots \ldots$ & $\begin{array}{l}\text { Through } 4 \text {-3/s } \\
\text { Over } 3.1 / 4 \text { to } 3\end{array}$ & 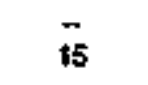 & $\overline{7+1 / 2}$ & $\begin{array}{c}1-1 / 2 \\
=\end{array}$ & $\begin{array}{l}2 \\
-\end{array}$ & $\begin{array}{l}11 \\
-\end{array}$ \\
\hline Stove $+\ldots+\ldots \ldots \ldots+\ldots \ldots++$ & $\begin{array}{l}\text { Through 2-7f16 } \\
\text { Over 1-5ta }\end{array}$ & $\overline{15}$ & $\overline{7+1 / 2}$ & $\begin{array}{l}2 \\
-\end{array}$ & $\begin{array}{l}3 \\
-\end{array}$ & $\begin{array}{l}11 \\
-\end{array}$ \\
\hline Chostmut,$\ldots \ldots+\ldots \ldots+\ldots \ldots$ & $\begin{array}{l}\text { Through 1-5/8 } \\
\text { owee } 19 / 16\end{array}$ & $\frac{-}{15}$ & $\overline{7-1 / 2}$ & $\begin{array}{l}3 \\
-\end{array}$ & $\begin{array}{l}4 \\
-\end{array}$ & $\begin{array}{l}11 \\
-\end{array}$ \\
\hline Euckwheat No, $1 \ldots \ldots \ldots+\ldots \ldots$ & $\begin{array}{l}\text { Throwgh gina } \\
\text { Over 5/16 }\end{array}$ & $\frac{-}{15}$ & $\overline{7-1 / 2}$ & $\begin{array}{l}- \\
-\end{array}$ & $\overline{-}$ & 13 \\
\hline Eudtuhnoax No. 2 (rtee) $\ldots \ldots \ldots \ldots$ & $\begin{array}{l}\text { Through 5/16 } \\
\text { Over ar16 }\end{array}$ & + & $7-1 / 2$ & $\overline{-}$ & 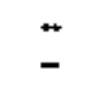 & $\begin{array}{l}13 \\
-\end{array}$ \\
\hline Euchunhest No. 3 (bartay) $\ldots \ldots \ldots$ & $\begin{array}{l}\text { Through } 3 / 16 \\
\text { Over sise }\end{array}$ & 20 & 10 & $\ddot{-}$ & $\ddot{n}$ & $\begin{array}{l}15 \\
-\end{array}$ \\
\hline Euckmhat No. $4 \ldots \ldots \ldots \ldots$ & $\begin{array}{l}\text { Through } 3132 \\
\text { Ower } 3444\end{array}$ & $\stackrel{+}{s 0}$ & $\overline{10}$ & $\ddot{*}$ & $\stackrel{-}{*}$ & $\begin{array}{l}15 \\
-\end{array}$ \\
\hline
\end{tabular}

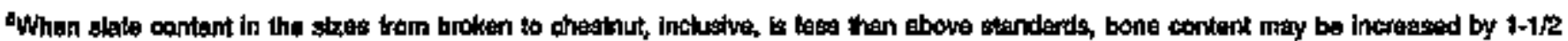

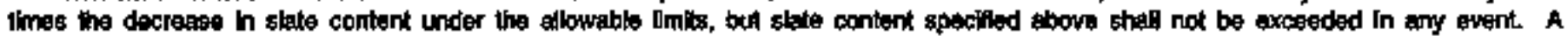

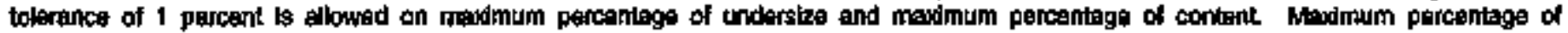

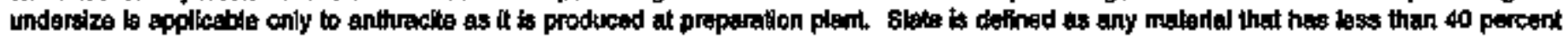
thoed cartibt. Eonte is doffined as any moterial that has 40 percent or more, but less than 75 pencent, fixed carbon.

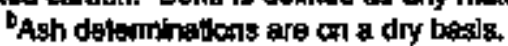

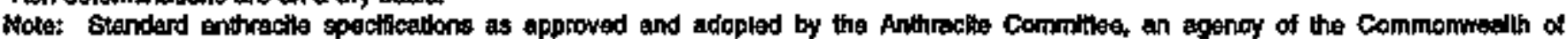

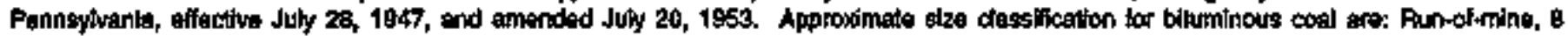

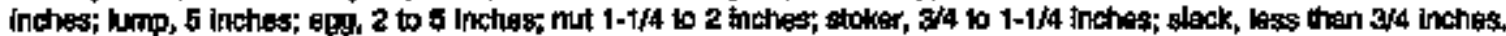

- Not eppllceble.

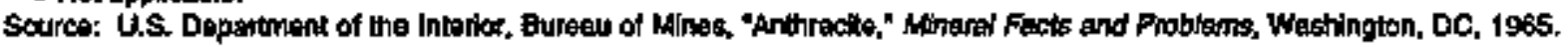





\section{Coal Terminology and Related Information}

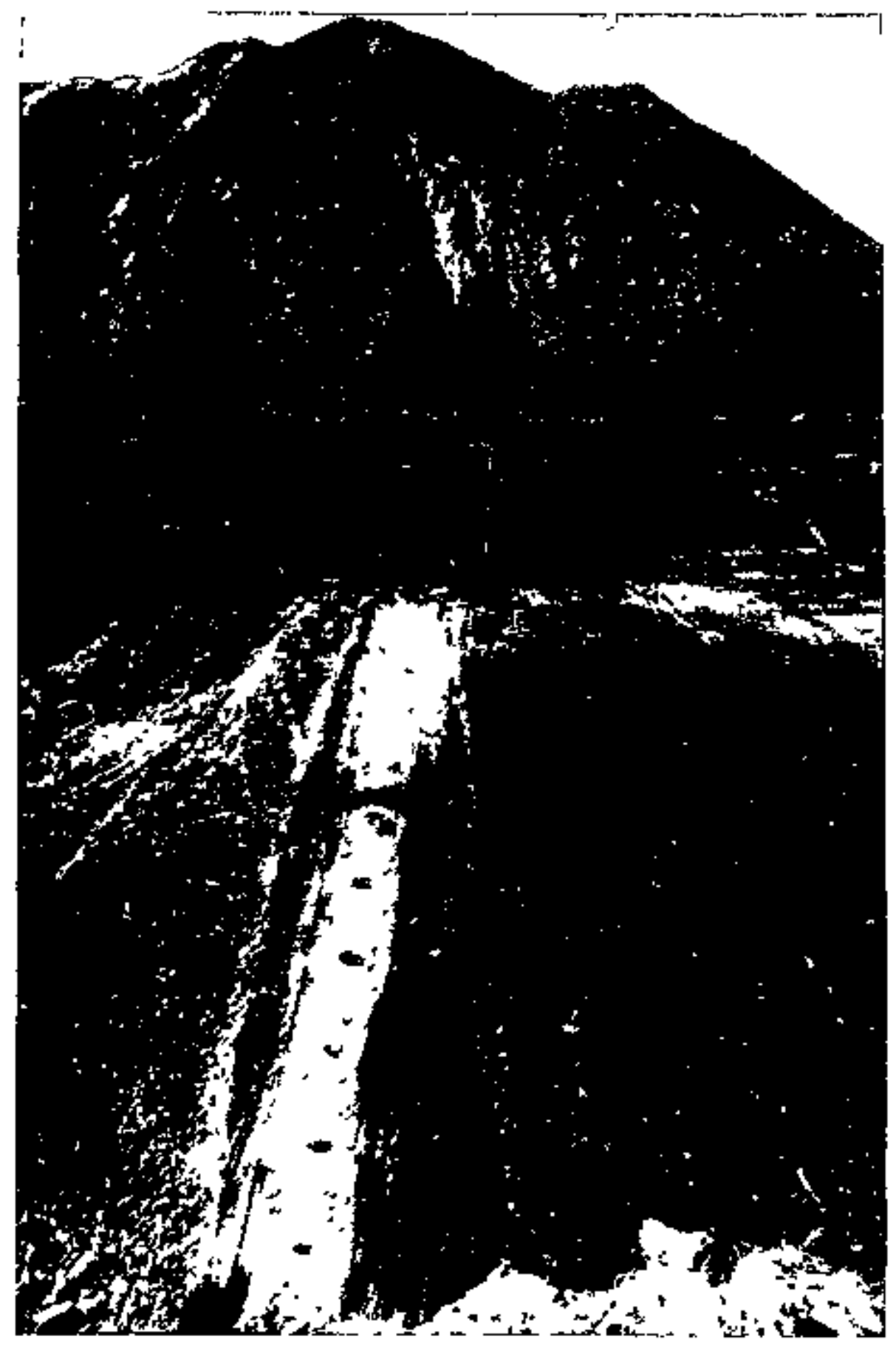

An alectric dill prepans overburden for blastring by borng hales in a prescribed pattem, makng it easter to excevate. The spoil pus in the background is overturden semoved from another part of the nune. 


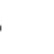
- 


\section{Coal Terminology and Related Information}

Acid Mine Drainage This refers to water pollyytion that results when sulfur-bearing minerals associated with coal are exposed to air and water and form sulfuric acid and ferrous sulfate. The ferrous sulfate can further react to form ferric hydroxide, or yellowbey, a yellow-okange iron precipitate fotand in streams and rivers pollufed by acld mine dratnage.

Acld Rain: Also called acid precipitation or acld deposition, acid rain is precippitation containing harmful amounts of nitric and sulfuric acids former primarily by nitrogen oxides and sulfur oxides released into the atmosphere when fossil fuels are burned. It can be wet precipitation (rain, snow, or fog) or dry precipitation (absorbed gaseous and particulate matter, aerosol particles, or dust). Acid rain has a pH below 5.6. Normal rain has a pH of about 5.6, which is slightly acidic. The term $\mathrm{pH}$ is a measure of acidity or alkalinity on a tange from 0 to 14. Readings below 7, which is neutral, indicate increased acidity; readings above 7 indicate increased alkalinity.

As-Received Coal: Coal in the condition as received by the consumer or the leboratory analyzing the coal.

Bone Coal: Coal with a high ash content (25 to 50 percent, by weight); it is dull in appearance, hard, and compact.

Btu (British thermal urit): A measure of energy, the Btu is the amount of heat needed to raise the temperature of 1 pound of water (approximately 1 pint) by 1 degree Fahrenheit. The Bhu is a convenient measure by which to compare the energy content of various tuels. One Btu of energy is approximately equivalent to the heat from one match tip. Heat available from coal, expressed as Btu per pound or ton, is a major factor in coal price

Captive Coal: This refers to coal produced and consumed by the mine operator, a subsidiary, or the parent company (for example, steel companies and electric utilities).

Coal Analysia: This determines the composition and properties of cogl so it can be ranked and used most effectively.
Proximate amalysis determines the behavior of a coal when burned. It measures (in percent) the moisture content, volatile matter (gases released when coal is heated, principally hydrogen, carbon dioxide, carbon monoxide, and various compounds of catbon and hydrogen), fixed carbon (solid combustible residue remaining after the volatile matter is driven offprincipally carbon, but may contain sulfur, hydrogen, nitrogen, and oxygen), and ash (incombustble matter consisting of silica, iron, alumina, and other material similar to ordinary sand, silt, and clay). The moisture content affects the ease with which coal can be handled and bumed. Volatile matter and fixed carbon provide guidelines for determining the Intensity of the heat produced (volatile mateer infuences the tgnitability and overall conbustion of a coal and contributes about 25 to 40 percent of the heat; fixed carbon, 60 to 75 percent). Ash increases the weight of coal, adds to the cost of hardling and can cause fuel bed and fumace problems due to the formation of clinkers (fused ash) and slag (meited ash that sticks to fumace walis). Proximate analysis may be reported in several ways, such as "as received," "dry," and "dry, mineral-matterfree (dmmt)." Proximate analysis is commonly used in industrial applications, such as in the purchase of coal for electricity generation.

Ullimate analysis determines the percentage of carbon, hydrogen, oxygen, ritrogen, sulfur, and ash. It may be reported in several ways, such as "as received, "dry," and "dry, mineral-matter-free (dmur)." UJimate analysis is used for a more thorough scientiffc investigation of coal.

Heating anlue, or heaf content, is determined in terms of Bh, both on an as-received basis (including moisture) and on a dry basis. It is the amount of heat released by the complete combustion of a specifled quantity of coal (ustally 1 pound or 1 short ton) as carbon and hydrogen combine with oxygen in the air to produce carbon dioxide and water. Higher heating zaltue (HHV), or gross heat content, includes the amount of energy used to transform the water into steam. Lower heating waine, or ntet hent content, excludes the energy used to vaporize the water and is generally calculated to be 93 to 97 percent of the gross heat value. RIA conversion fartors typically represent gross heat content. 


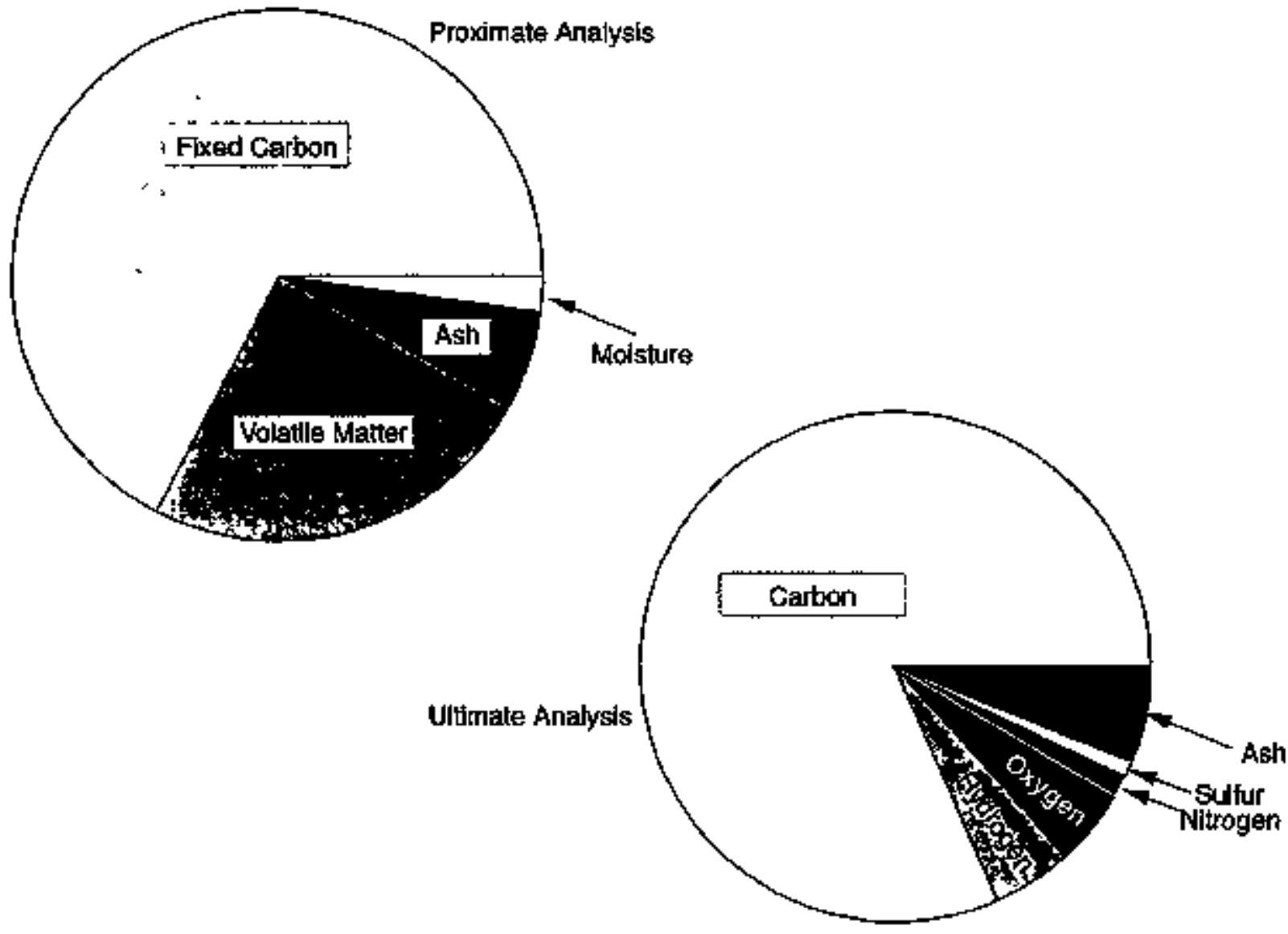

Two different types of analyses of a blturninous coos.

Agglonterating refers to coal that softens when heated and forms a hatd gray coke; this cool is called caking conI. Not all caking coals are coktrig coals. The agglomerating value is used to differentiate between coal ranks and also is a guide to determine how a particular coal reacts in a furnace.

Agglutinating refers to the binding qualities of a coal. The agglutinating vatue is an indication of how well a coke made from a particular coal will perform in a blast funace. It is also called a caking index.

Other analyses include the determination of the ashsoftening temperature, the ash-fusion temperature (the temperafure at which the ash forms clinkexs or slag), the free-swelling index (a guide to a coal's coking characteristics), the Gray-King assay (determines the suitability of coal for making coke), and the Hardgrove Grindability Index, or HGI (a measise of the ease with which coal can be pulverized as compared with a "standard" coal with a 100 HGI value; the lower the index, the harder to grind and vice-versa). In a petrographic analysis, thin sections of coal or highly polished blocks of coll are studied with a microscope to determine the physical composition, both for scientific purposes and for estimating the rank and coking potential.

Coal Blending: The process of combining two or more coals with different characteristics to obtain coal with a certain quality, such as a low sulfur content.

Coal Chemicals: Coal chemicals are obtained from the gases and vapor recovered from the manufacturing of coke Generally, crude tar, ammonja, crude light oil, and gas are the basic products recovered. They are refined or processed to yield a variety of chenical materials. 
Coal Classification: in the United States, coals ate classified by rank progxessively from lignite (least carbonaceous) to anthracite (most carbonaceous) based on the proximate analyses of various properties (fixed carton, volatile matter, heating value, and agglomenting character), following methods prescribed by the American Society for Testing and Materials. The International Coal Classification of the Econom te Commission for Europe recognizes two broad categories of coal, "brown coal" and "hard coal." In terms of U.S. coal classification, the international classification of brown coal includes lignite and lower-ranked subbituminous coal, whereas hard coal includes all higher rank coals.

Coal Face: This is the exposed area from which coal is extracted.

Coal Fines: Coal with a maximum particle size usually less than one-sixteenth inch and rarely above oneeighth inch

Coal Grade: This classification refers to coal quality and use. The classification includes the following categories:

Brigueties are made from compressed coal dust, with or without a binding agent such as asphalt.

Cleaned coal or prepared coal has been processed to reduce the amount of impurities present and improve the buming characteristics.

Complinuce coal is a coal, or a blend of coal, that meets sulfur dioxide emission standards for air qualtsy without the need for flue gas desulfurization.

Culm and silt are waste materials from preparation plants. In the anthracite region, culm consists of coarse rock fragtnents contatuing as much as 30 percent smallsized coal. Silt is a mixture of very fine coal particles (approximately 40 percent) and rock dust that has settled out from waste water from the plants. The terms culm and silt are sometimes used interchangeably and are sometimes called refuse. Culn and silt have a heat value ranging from 8 to 17 million Btu per ton.

Low-ash coal contains less than 8 percent ash by weight; mediton-ash canl, 8 percent to less than 15 percent by weight; high-asit canl, more than 15 percent ash by weight.

Low-sulfur coal contains 1 percent or less sulfur by weight. For air quality standards, "Iow-sulfur coal" contains 0.6 pounds or less sulfur per million Biu (equivalent to 1.2 pounds of sulfur dioxide per million Btu). Medituti-sulfur corl contains more than 1 percent to less than 3 percent sulfur by weight: 0.61 to 1.67 pounds of silfur per million Btu. High-sulfir conl contains more than 3 percent sulfur by weight; more than 1.67 pounds of sulfur per million Btu.

Metaliturgical coal (or coking coal) is a coal that can be converted into coke. It must have a low ash and sulfurr content and form a coke that is strong enough to support the weight of iron ore and limestone in a blast furnace. A blend of two or more bifuminous coals is usually required to make coke.

Puiverized coni is coal that has been crushed to a fine dust in a grinding mill, It is blown into the combustion zone of a fumace and bums very rapidly and efficiently+

Stack cord usually refers to bituminous coal one-half inch or smaller in stze.

Steam cont refers to coal used in boilers to generate steam to produce electricity or for other purposes.

Stoker coal refers to coal that has been crushed to specific sizes (but not powdered) for burning on a grate in automatic firing eçuipment.

Coal Preparation (Cleaning/Beneficiation/Processing) Processes:

Dense (heavy) medium pracesses use a thick solution, usually a mixture of magnetite and water, to separate coal from impunties by gravity separation.

Flobation processes treat fine-sized conl with an oil-based reagent that attracts air bubbles in a liquid medium; the coal floats to the surface as a froth, leaving the refuse below.

Hydraulic processes use currents of water to separate coal from impurities.

Pnemmatic processes use currents of air to separate coal from impurities.

Coal Rark: This classification is based on the fixed carbon, volatile matter, and heating value. It is an indication of the progressive alteration, or coalification, from ligntte to anthractle. Rank can also be determined by measuring the reflectonce of titrinite, one of the several orgaric components (macerals) of coal.

Lignite, the lowest rank of coal, is brownish black and has a high moisture content, sometimes as high as 45 
percent. It tends to disintegrate when exposed to weather. The heat content of lignite ranges from 9 to 17 mitlion Bhu per ton as recesved and averages about 14 million Btu per ton. The ignition temperature is approximately 600 degrees Fahrenheit. Lignite is mined In California, Louisiana, Monkana, North Dakota, and Texas, and is used mainly to generate electricity in power plants that are relatively close to the mines. The term "lignite" is used interchangeably with "brown $\mathrm{coal}^{N}$ in other countries.

Subbituminous coal, or black lignite, is dull black and usually contains 20 to 30 percent moisture. The heat content of subbinminous coal ranges from 16 to 24 million Btu per ton as received and averages about 18 rtillion Btu per ton. Subbituminous coal, mined in westem coal fields (notably the Powder Rfver Basin), is used mostly for generating electricity.

Bituminous coal, or soft coal, is the most comwton coal. It is dense, black, often with well-defined bands of bright and dull material. Its moisture content usually is less than 20 percent. The heating value ranges from 19 to 30 million Btu per ton as received and averages about 24 million Btu per ton. The ignition temperature ranges from about 700 to almost 900 degrees Fahrenheit. Bituminous coal is mined chiefly in Appalachian and interior coal fields. It is used for generating electricity, making coke, and space heating.

Anthracite, or kard cont, is the highest rank of econonically usable coal. It is jet black with a high luster. The moisture content generally is less than 15 percent. Anthracite contzins approximately 22 to 28 million Btu per ton as received and averages about 25 million Btu per ton. Its igntion temperature is approximately 925 to 970 degrees Fahrenheit. Virtually all of the anthracite mined is from northeastern Pennsylvania. It is used mostly for space heating and generating efectricity.

Meta-anthracite, the highest rank of coal, is a low-quality fuel It is dull gray ot black, and has a high ash content. It was intermittently mined in the Narraganset Basin of Rhode tsiand and Massachusetts. The last mine, at Cranston, Rhode Island, closed in 1959. Coal from the area averaged about 19 million Btu per ton as recelved.

Coal Sulfur: Conl sulfur occurs in three formas: orgonic, sulfate, and pyritic. Orgaric sulfur is an integral part of the coal matrix and cannot be removed by conventional physical separation. Sulfate sulfur is usually negligible. Pyritic sulfur occurs as the minerals pyrite and marcasite; larger sizes generally can be removed by cleaning the coal.
Coal Type: This classification is based on physical characteristics or microscopic constituents. Examples of coal types are banded coal, bogitend coal, bright cosl, connel coal, and splint coal. The term is also used to classify coal according to heat and sulfur content. (See Coal Grade.)

Coalbed Degasification: This refers to the removal of methane, or coalled gos, from a coal mine before or during mining.

Coalbed Methane: Methane is generated during coal formation and is contained in the coal mickostructure. Typical recovery entails pumping water out of the coal to allow the gas to escape. Methane is the principal comportent of natural gas. Coalbed methare can be added to natural gas pipeltres without any special treatment.

Coke: Coke is a combustible restdue consisting of residual ash and fixed carbon made from bituminous coal (or blends of bituminous coal) from which the volatile constituents are driven off by baking in an oven at temperatures as high as 2,000 degrees Fahrenheit. The process is called carbonization. Coke is hard and porous, has a gray, stabmetallic luster, and is strong enough to suppost a load of iron ore in a blast fumace. It is used chiefty as a fuel and reducing agent in smelting iron ore in a blast furnace. Coke has a heat value of about 25 million Btu per ton.

Coke Battery: A series of adjacent coke ovens, usually 45 or more, sharing coal charging and byproduct control equipment.

Coke Breeze: The term refers to the fine sizes of crushed coke that will pass through a 1/2-inch of 3/-inch screen opening. It is commonly used for sintering (agglomerating) iron ore, a process in which fine ote is miked with coke and igrited to produce semifused lumps of ore.

Coke Button: A button-shaped piece of coke resulting from a standard laboratory test that indicates the coking ot free-swelling characteristics of a coal; expressed in numbers and compared with a standard.

Coke Oven: An individual coking chamber made of silina brick walls and ranging from 4 to 14 feet in height, 30 to 45 feet in length, and 1 to 2 feet in width. Byproduct ovens contain a series of long, narrow chambers arranged in rows and heated by flues in which are bumed a portion of the combustible gases generated by the coking of coal. All the volatile 
products are collected as ammonia, tar, and gas, and tray be further processed into other byproducts.

Coke-Oven Gas: This by-product of coke production is used as fuel for heating coke ovens, generating steam and producing heat for other purposes.

Fossil Fuel: Fuel such as coal, crude oil, or natural gas, formed from the fossil remains of organic matertal.

Fondry Coke: This is a special coke, generally 3 inches and larger in size, that is used in furnaces to produce cast and ductile iron products. It is a source of heat and also helps maintain the required carton content of the metal product. Foundry coke production requires lower temperatures and longer times than blast furnace coke.

Fuel Ratio: The ratto of fixed carbon to volable ratter In exal.

Gob: This refers to the caved area of broken rock in an underground mine. A gob pile is a heap of waste from preparation plants.

Interburden: The material that separates the coalbeds of a surface deposit.

Middlings: In coal preparation, this material, also called mid-coal, is neither clean coal nor refuse; due to their intermediate specific gravity, middlings sink only partway in the washing vessels and are removed by auxilliary means.

Open-Market Coal; Coal that is sold on the commercial market, in contrast to captive coal,

Overburden: Any material, consolidated or unconsolidated, that overlies a coal deposit Ougrburden ratio (stripging ratio) refers to the amount of overburclen that must be removed to excavate a given quantity of coal. It is commanly expressed in cubic yards per ton of coal, but is sometimes expressed as a ratio comparing the thickness of the overbirden with the thickness of the coalbed. Spotl is the overburden removed in gaining access to a coalbed in surface mining. Sullif frctor is the ratio of the increase in volume, normally expressed as a percenage, that occurs in the overburden material when it is excavated and deposited in a loose state.

Parting: A layer of rock within a coalbed that lies roughly parallel to the coalbed and has the effect of splitting the bed into two divisions.
Peat: Peat is partially decomposed plant debris, and is considered an early stage in the development of coal. Peat is distinguished from lignite by the presence of free cellulose and a high tnoisture content (exceeding 70 percent). The heat content of air-dried peat (about 50 percent moisture) is abort 9 million Btu per ton. Most U.S. peat is used as a soil conditioner. The first U.S. electric power plant fueled by peat began operation in Maine in 1990.

Raw Coalt: Coal that has received no preparation other than possibly screening.

Round Test Mesh: A sieving screen with round holes, the dimensions of which are of specific sizes to allow certain sizes of coal to pass through while retaining other sizes.

Rtun-of-Mine Coat: Coal as it comes from the mine prior to screening or any other treatment.

Screenings: The undersized coal from a screening process, usually one-half inch or smaller.

Solvent Refined Coal (SRC): A tar-like hrel produced from coal when it is crushed and mixed with a hydrocarbon solvent at high temperature and pressiure.

Spontaneots Combuetion, or Self-Heating of Coal: A naturally occurring proce caused by the oxidation of coal. It is most common in low-rank coals and is a potential problem in storing and transporting coal for extended periods. Factors involved in spontaneous combustion include the stze of the coal (the smaller sizes are more susceptible), the moisture content, and the sulfur content. Heat buildup in stored coel can degrade the quality of coal, cause it to smolder, and lead to a fire.

Sturface Mining Equipment:

An auger machine is a barge horizontal drill, generally 3 feet or more in diameter and up to about 100 feet long. It can remove coal at a rate of more than 25 tons per minute.

A bucket-wohel excutritor is a continuous-digging machine equipped with a boom that has a rotating wheel with buckets along its edge. The buckets scoop up inaterial, then empty onto a conveyor leading to a spoil bank. This excavator is best suited for removing overburden that does not require blasting. It is also used in combination with conveyors to move topsoil from areas to be mined to storage. 
A bulldozer is a tractor with a movable steel blade mounted on the front. It can be used to remove overburden that needs little or no blasting.

A corryoll scraper (or pon scraper) is a self-loading tnachine, usually self-propelled, with a scraper-like retractabie bottom. It is used to excavate and haul overburden.

A continuous sutface minet, used in sorne lignite mines, is equipped with crawlers, a rotating culting head, and a conveyor. It travels over the bed, excravating a swath up to 13 feet wide and 2 feet deep.

A dragline excatsitor removes overburden to expose the coal by means of a scoop bucket that is suspended from a long boom. The dragline digs by pulling the bucket toward the machine by means of a wire rope.

A wakking dragline is equipped with large outrigger platforms, or walking beams, instead of crawler tracks. It "walks" by the altemate movement of the walking beams.

A drilling rig is used to deternire the amount and type of overburden overlying a coal deposit and the extent of the deposit, to delineate major geologic features, and to drill holes for explosives to fragment the overburden for easier removal.

A front-end loader is a tractor with a digging bucket mounted and operated on the front. it is often used to remove overburden in contour mining and to Ioad coal.

A hydraulic shotel excavates and loads by means of a bucket attached to a rigid arm that is hinged to a boont.

A pouter stotol removes overburden and loads coal by means of a digging bucket mounted at the end of an arm suspended from a boom. The shovel digs by pushing the bucket forward and upward. It does not dig below the level at which it stands.

A thin-seam miner resembles an auger machine but has a drum-type cutting head that cuts a rectangular cross section.

\section{Surface Mining Methods:}

An auger mine recovers coal through the use of a largediameter drill driven into a coalbed in the side of a surface mine pit. It usually follows contour surface mining, patticularly when the overburden is too costly to excavate. (See also punch mine a type of underground mine.)
Area mining is practiced on relatively flat or gently rolling terrain. It recovers coal by mining long strips successively; the material excavated from the strip being mined is deposited in the strip pit previously mired.

A bench is a ledge in a suzface mine that forms a step from which excavation will take place at a constant level.

A box cut is the first cut made to remove the overburden from the coal where no open side exists; this results in a highwall on both sides of the cut. The overburden is placed on urumined land, normally outside the area to be mined.

Contour mining is practiced when the coal is mined on killsides. The mining follows the contour of the hillside until the overburden becomes uneconomical to remove. This method creates a shelf, or bench, on the hillside. Several variations of contour mining have been developed to confrol environmental problems. These methods include siope reduction (overburden is spread so that the angle of the slope on the hillside is reduced), heal-of hollow fill (overburden is placed in narrow V-shaped valleys to control erosion), and blockcut (overburden from current mining is backfilled into a previously mined cut).

Explosizes casting is a techrique designed to blast up to 65 percent of the overburden into the mine pit for easier removal. It differs from conventional overbuxden blasting, which only fractures the overbuzden before it is removed by excavating equipment.

A hightopll is the unexcavated face of exposed overburden and coal in a surface mine.

Mountainiop miming, sometimes considered a variation of contour mining refers to the mining of a coalbed that underites the top of a cnountain. The overburden, which is the mountaintop, is completely removed so that all of the coal can be recovered. The overburden material is later replaced in the mined-out area. This method leaves large plateaus of level land.

Open-pit caal mining is essentially a combination of contour and area mining methods and is used to mine thick, steeply inclined coalbeds. The overburden is removed by power shovets and trucks.

Tipplet Originally, the place on the surface where mine cars were tipped or emptied of their coal, but now expanded to include the place where trucks, railroad cars, or conveyors hauling coal from a mine dump 
the coal. Sometimes applted to the surface structures of a mine, including the preparation plant and loading tracks.

\section{Underground Mining Equipment:}

An amoved face conturyor is used to transport coal from the face of a longwall operation and also to support the shearing machine or plow.

A coal-cutting machine is used in convertional minung to undercut, topcut, or shear the coal face so that coal can be frachured easily when blasted. It cuts 9 to 13 feet into the bed.

A continuous auger machine is used in miring coalbeds less than 3 feet thick. The auger has a cutting depth of about 5 feet and is 20 to 28 inches in diameter. Continuous auger mining usually uses a conveyor belt to haul the coal to the surface.

A continuous-mining machine, used during continutous mining, cuts or rips coal from the face and loads it into shuttle cars or conveyors in one operation. It eliminates the use of blasting devices and performs many functions of other equipment such as drtlls, cutting machines, and loaders. A conttnuous-mining machine typically has a turning "drum" with sharp bits that cut and dig out the coal for 16 to 22 feet before mining stops so that the rtured azea can be supported with roof bolts. This machine can mine coal at the rate of 8 to 15 tons per minute.

Conveyor systems consist of two types. A matinline conveyor is usually a permanent installation that carries coal to the surface. A section conteyor connects the working face to the mainline conveyor.

A face drill is used in conventional mining to drill shotholes in the coalbed for explosive charges.

A londing muchine is used in conventional mining to scoop broken coal from the working area and load it into a shutile car, which hauls the coal to mine cars or conveyors for delivery to the surface.

A mine lacomolitue, operating on tracks, is used to haul mune cars contzining coal and other material, and to move personnel in specially designed "mantrip" cars. Lange locomotives can hatul more than 20 tons at a speed of about 10 miles per hour. Most mine locomotives run on electricity provided by a trolley wire; some are battery-powered.

A plow is a longwall-mining machine with a blade that has fixed bits or a saw-toothed edge.
A ran car, or shutlle ran, is a rubber-tired haulage vehicle that is unioaded through the use of a movable steel plate located at the back of the haulage bed.

A roof-bolting machine, or roof boifer, is used to drill holes and place bolts to suppott the mine roof. Roof bolting units can be installed on a continuous-mining machine.

A scoop is a rubber-tired haulage vehicle used in thin coalbeds.

A shetrer is a longwall-mining machine with one or two rotating cutting drums.

A shield is a movable roof support used in longwall mining.

A shortwall-minting machine generally is a continuousmining machine used with a powered, self-advancing roof support system. It shears coal from a short coal face (up to about 150 feet long). The broken coal is hauled by shuttle cars to a conveyor belt.

A shititie or is a rubber-tired haulage vehicle that is unloaded by a built-in conveyos.

Underground Mining Methods:

A cross cul in an underground mine is a short tunnel connecting two parallel entries.

Dezelopment refers to the nuning meeded to provide access to the area to be produced. It includes driving shafts and slopes.

A drift mine is driven horizontally into coal that is exposed or acoessible in a hillside.

An eniry in an underground mine is a tunnel-like passage, usually driven entirely within the coalbed and rectangular in cross section, typicaily about 6 feet high and 20 feet wide. The number of entries is determined by the requirements for ventilation, hatlage, escapeways, and mine services such as power, water, and drainage.

In a hydraulic mine, high-pressure water jets break the coal from a steeply indined, thick coalbed that would be difficult to mine with the usual underground methods. The coll is then transported to the surface by a system of flumes or by pipetine. Although currently not in commercial use in the Untted States, hydraulic mining is used in western Canada.

In Iongavil mining, a parnel, or block, of coal generally about 700 feet wide and often over 1 mile long is 
completely extracted, leaving no pillars to support the mined-out area. The working area is protected by a movable, powered roof support system. The caved area (gob) compacts and, after initial subsidence, supports the overlying strata. Longwall mining is used where the coalbed is thick and generally flat, and where surface subsidence is acceptable

A portal is the surface entrance to an underground mine. It is the point where the main haulage and ventilation entries of the mine intersect the earth's surface.

A punch mine is a type of small drift mine used to recover coal from strip-mine highwalls or from small, otherwise uneconomical, coal deposits.

Rock dusting, sprayed in an underground coal mine, reduces the possibility of coal dust explosions. Rock dust is a very fine noncombustible material, usually pulverized limestone.

Roof bolting is the principal method of supporting the mine roof. In roof bolting, long bolts, 2 to 10 feet long with an expansion shell or with resin grouting, are placed in the mine roof. The bolts reinforce the roof by pulling together rock strata to make a strong beam, or by fastening weak strata to strong strata.

In a room-and-pillar mining system, the most common method, the mine roof is supported mainly by coal pillars left at regular intervals. Rooms are places where the coal is mined; pillars are areas of coal left between the rooms. Room-and-pillar mining is done either by (1) conventional mining, which involves a series of operations that require cutting the working face of the coalbed so that it breaks easily when blasted with explosives or high-pressure atr, and then loading the broken cost or (2) continuous mining, in which a continutows mining machine extracts and removes coal from the working face in one operation. When a section of a mine has been fully developed, additional coal may be extracted by mining the supportive pillars until the roof caves in; this procedure is called room-and-piflar retreat mining.

A shaft mine is driven vertically to the coal deposit.

A shorturll mining system generally refers to room-andpillar mining in which the working face is wider than usual but smaller (less than 150 feet) than that in longwall mining.

A slope mine is driven at an angle to reach the coal deposit.

Ventilation, accomplished with large fans, is essential to supply fresh air and to remove gases and dust from the mine. 


\section{Bibliography}

\section{Books and Nongovernment Reports}

Association of American Railroads. Analysis of Class I Raitroad5 1987. Washington, DC, 1988.

Association of American Railroads. Freight Commontity Slatistics 1993. Washington, DC, 1993.

Association of American Railroads. Railraed Facts 1993 Edition. Washington, DC, 1993.

Bailey, Maurice E. Conl and Other Rachs: The Gelogy of Coal Meastares. Pikeville, KY: Pikeville College Press, 1984.

Bend, S. L. "The Origin, Formation and Petrographic Composition of Coal," Fuel 71:8, August 1992

Berkowitz, Noibert. An Intraduction to Coal Technology, 2nd ed. New York, NY: Academic Press, 1994.

Berkowitz, Nohbert. The Chentistry of Coal. New York, NY: Elsevier Science Publishing Co., 1985.

Cooper, Bentard $\mathrm{R}$, and Elingson, William A, Ed. The Science and Technology of Coul and Coal Ltilization. New York, NY: Plenum Press, 1984.

Crickmer, Douglas F., and Zegeer, David A. Ed. Elements of Practical Conl Mining, 2d ed. New York, NY: Society of Mining Engineers, American Institute of Mining, Metallurgical, and Petroleum Engineers, Inc., 1981.

Dbon, Thomas W., Ir. Appalachion Caal Mines E Roilroads. Lynchburg, VA: TLC Publishing, Inc., 1994.

Eavenson, Howard N. The First Century and a Quarter of American Coul Indistry. Baltimore, MD: Waverly Press, Inc., 1942.

Edison Electric Institute. Environmental Directory of U.S. Power Plonts 1992. Washington, DC, 1992.

Elliott, Martin A, Ed. Chemistry of Caal Utilization, Second Supplementary Volume New York, NY: WileyInterscience, 1981.
Elliott, Thomas C., Ed. Standard Handboak of Potoerplant Engineering. New York, $\mathrm{NX}$ : McGraw-Hill Publishing Co., 1989.

Fieldston Cont Transportation Martual 1994. Washington, DC: Fieldston Publishing, Inc, 1994.

Francis, Wilfrid. Cod: Its Fommation and Compostinon, and ed. London: Edward Amold, 1961.

Gronhovd, G.H, and others. Lotv-Rank Coal Technology: Lignite and Subbiluminous. Fark Ridge, Nj: Noyes Data Corp. 1982.

Hartuan, Howard L., Ed. SME Mining Engineering Handbook, 2nd ed. Littleton, $\infty$ : Sociely for Mining, Metallurgy, and Exploration, Inc, 1992.

Hawley, Mones E., Ed. Conl, Port I: Socinl, Econtomic, and Entironmental Aspects. Benchmark Papers on Energy, Vol. 3. Stroudsburg PA: Dowden, Hutchinson, \& Ross, Inc, 1976.

Hawley, Mones E, Ed Coul, Part II: Scientific and Techntical Aspects. Benchmark Papers on Energy, Vol. 4. Stroudsburg, PA: Dowden, Hutchinson, \& Ross, Inc., 1976.

Hessley, Rita $K_{\text {, }}$ Reasoner, John $W$, and Riley, John T, Cal Science* An Introduction to Chemistry, Technology, and Ubilization. Somerset, NJ: John Wiley \& Sons, Inc, 1986.

Horton, Aaron Thomas, and Bloon, Meredith A. "1993 Prep Plant Census. ${ }^{*}$ Coll 98, September 1993.

International Energy Agency. Coal Information 1992. Paris, France, 1992

International Energy Agency. Concise Guide to Word Coalfields. London, England: World Coal Resources and Reserves Data Bank Service, 1983.

Keystone Caal Industry Monual 2994. Chicago, IL: MacLean Hunter Publishing Co., 1993.

Lake Carriers' Assoctation. 1993 Annual Report of Lake Comiers' Assuciation. Cleveland, OH, 1994. 
Leonard, Joseph W., Ed. Coal Preparation, 4th ed. New York, NY: Society of Mining Engineers, American Institute of Mining, Metallurgical, and Petroleum Engineers, Inc., 1979.

Merritt, Roy D. Coal Exploration, Mine Plenning, and Development. Park Ridge, NJ: Noyes Data Corp., 1986.

Meyers, Robert A, ed. Coal Handboak. New York, NY: Marcel Dekker, Inc., 1981.

Moore, Elwood 5. Conl: Its Properties, Analysis, Classification, Geolozy, Extraction, Uses and Distribution, 2d ed. New York, NY: John Wiley \& Sons, 1940.

Murchison, Duncan G, and Westoll, R. Stanley, Ed. Coal and Cool-Bearing Stmta. New York, NY: Elsevier, 1968 .

National Coal Association. Coal Data 1994 Edition. Washington, DC. 1994

National Coal Association Coal Transportation Statistics 1993 Edition. Washington, DC 1993.

National Coal Association. Facts About Coal 1994. Washington, DC 1994.

National Coal Association. International Coal Review Anrual 1994. Washington, DC 1994.

Peng, Syd S. Coal Mine Ground Control, 2nd ed. New York, NY: John Wiley \& Sons, 1986.

Peng, Syd S., and Chiang, H. S. Longuall Mining. New York, NY: John Wiley \& Sons, 1984.

Petroleura Information Corporation. Coalbed Methane: An Old Hazard Becontes a Netp Resotzce. Petroleum Frontiers, Vol. 3, No. 4. Denvec, CO, 1986.

Rase, Adam, and Frias, Oscar. The Impact of Coul on the U.S. Economy. Report to the National Conl Assaciation. Washington, DC: The National Coal Association, 1994.

Ross, Charles A., and Ross, Jume R. P. Ed. Geology of Conl. Berchmark Papers in Geology, Vol. 77. New York, NY: Van Nostrand, 1984.

Sieam, Its Generation and Use, 40 th ed. Barberton, $\mathrm{OH}$ : The Babcock \& Wilcox Co., 1992.

Stefanko, Robert. Coal Miting Technology: Theory and Practice. New York, NY: Society of Mining Engtheers,
American Instibute of Mining Metallurgical, and Petroletum Engineers, Enc., 1983.

The Presideni's Commission on Coal. The American Coal Miner. A Report on Comnunity and Living Conditions in the Conlfields. Washington, DC, 1980.

Valkovic, Vado. Trace Elements in Coal, 2 Vols. Boca Raton, FL: CRC Press, Inc., 1983.

1993 U.S. Coal Export Manual. Washington, DC: Fieldston Publications, Inc., 1993.

\section{Perjodicals Containing Information on Coal}

AMC Journal. American Mining Congress, 1920 N St, N.W., Washington, DC 20036.

Coal (incorporates Coal Age and Conl Mining). Maclean Hurter Publishoning Co., 29 North Wacker Drive, Chicago, IL 60606.

Cool Neas. National Coal Association, 1130 17th St. N.W., Washington, DC 20036.

Caal Otuliook. Pasha Publications, 1401 Wilson B]vd., Suite 910, Arlington, VA 22209.

Cal \& Synfuels Technology. Pasha Publications, 1401 Wilson Blvd., Stite 910, Arlington, VA 22209.

Conl Transportation. Fieldston Publications, Enc., $1920 \mathrm{~N}$ St. N.W., Washington, DC 20036.

Coal Voice. National Coal Assoctation, 1130 17th St., N.W., Washington, DC 20036.

Coal Wetk McGraw-Hill, 1221 Avernue of the Americas, New York, NY 10020.

Electrical World. MacGraw-Hill, 1221 Avenue of the Americas, New York, NY 10029.

Inkemstional Coal. King Publishing Co., P.O. Box 52210, Knoxville, IN 37950 .

Intemational Joumal of Con! Geolozy. Elsevier Scientific Publishing Co., 100AH Amsterdarn, The Netherlands.

Journal of Caal Quatity. Westem Kentucky University, Bowling Green, KY 42101. 
Joumei of Commerce. 155 Michigan Avenue, Suite 700, Chicago, IL 60601.

Keystone News Bulletion. Maclean Hunter Publishing Co., 29 North Wacker Drive, Chicago, IL 60606.

Lmantarc. National Coal Association, 1130 17th St, N.W., Washington, DC 20036.

Minting Engingering, Society of Míning, Metallurgy, and Exploration, Inc., 8307 Shaffer Parkway, Littleton, CO $80127-5002$.

Northern Conl. King Publishing Co., P.O. Box 52210, Knoxville, TN 37\%50.

Potuer Engineering. Technical Publishing, P.O. Box 1030, Barrington, IL 6 DONO.

Qutrteriy Reojetw of Methane from Coal Seams TechnologyGas Research Institute, 8600 West Bryn Manor Ave., Chicage, Il 60631.

Southem Coul. King Publishing Co., P.O. Bax 52210, Knoxville, IN 37950.

United Mine Workers Journal. United Mine Workers of America, 900 15th St., NW., Washington, DC 20005.

Westem Coal. King Publishing Co., P.O. Box 52210, Knoxville, TN 37950.

World Mining Equipment. Technical Publishing, 875 Third Ave, New York, NY 10022.

\section{U.S Department of Energy}

"A Coal Combustion Pruner." PETC Reviety, Issue 2 Pittsburgh, PA, Septenber 1990, 9p. 15-19.

Assistant Secretary for Environment, Safety, and Health. Energy Technologies and the Environment: Enoironmental Information Handbook, DOE/EH-0077. Washington, DC, October 1988.

Assistant Secretary for Fosil Energy. Clean Coal Tecthologies: Reserrch, Dezelopment, and Demosstration Program Ptan, DOE/FE-0284. Washington, DC, November 1993.

Assistant Secretary for Fossil Energy. Clan Coal Technology: The Jnvestment Pays Off, DOE/FE-0291. Washington, DC, Jaruary 1994.
Assistant Secretary for Fossil Energy. Clean Coal Technology: The New Coal Era, DOE/FE-0913-P. Washington DC, June 1990.

Assistant Secretary for Fossil Energy. Clern Conl Tedtnolosy Dernonstration Program: Program Ljpdate 1993, DOE/FE-0299-P. Washington, DC, March 1994.

Assistant Secretary for Fossil Energy. Report to the United States Congress: Clean Coal Technology Export Markets aud Finencing Mechanisms, DOE/FE-0307P. Waskington, DC, May 1994.

Assistant Secretary for Fossil Energy. The Clean Coni Technology Program-Lessons Leamed, DOE/FE-031. Washington, DC, July 1994.

"Coal Prepazation: The Foundation for Modem Coal Use" PETC Review, Issue 5. Pittsburgh, PA, Spring 1992, pp. 4-13.

National Energy Stralegy: Powerful ldens for America. First Edition 1991/1992. Washington, DC, February 1991.

Nationat Energy Stmitegy: Potwerful Ideas for America, One Year Later. Washington, DC, February 1992.

Office of Fossil Energy. Caal Combustion Waste Management Study, DOE/FE/62017.H1. Washington, DC, February 1993.

Technical Information Center. U.S. Energy Deskbook, DOE/IR-051114-1. Oakridge, TN, June 1982.

"What is Coal?" PETC Review, Issue 10. Pittsburgh, PA, Summer 1994, pp. 22-28.

\section{Argonne National Laboratory}

Air Toxic Emissions from the Combustion of Coal: Identifying and Quontifying Hazardous Air Pollutants from U.S. Coals, ANL/EAIS/TM-83. Argonne, IL, September 1992.

\section{Energy Information Administration}

"A Profile of New Cosl Mines in the 1980's." Conl Production 1990, DOE/EIA-0118(90). Washington, DC, September 1991, pp. 1-12.

Annual Entergy Outlook 1993, DOE/EIA-0399(93). Washingtor, DC, January 1993. 
Annut Energy Reoiet 1993, DOE/EIA-0S84(93). Washington, DC, July 1994.

Anntal Outiook for U.S. Coal 1991, DOE/EIA-0333(91). Washington, DC, July 1991.

Annual Prospects for World Conl Trade 1991, DOE/EIA-0363(91). Washington, DC, Jtune 1991.

"Carbon Dioxide Emission Factors for Coal." Quarteriy Coul Report January-March 1994, DOE/EIA-0121 (94/10). Washington, DC, September 1994, pp. 1-B.

"Coal and the Railroads." Coal Distribution JanutryDecember 1985, DOE/ELA-0125(85/4Q). Washúngton, $\mathrm{DC}_{t}$ Apríl 1986, pp. 1-5.

"Coal Combustion: A Review of Coal Combustion Technology from Stokers to Flutdized Beds." Coal Distribution january-March 1987, DOE/EIA-0125(87/10). Washington, DC, July 1987, PP. $2-7$.

Coal Distribution Janteary-December 1991, DOE/EIA-0125 (91/4Q). Washington, DC, April 1991 and prior issutes.

Conl Industry Annut 1993, DOE/EIA-0584(93). Washington, DC, December 1994.

Cofi Production 1992, DOE/ELA-0118(92). Washington, DC, Ostober 1993 and prtor issues.

Cost and Quality of Fuels for Electric Utility Plants 1993, DOE/EIA-0191(93). Washington, DC, July 1994.

Eletiric Power Annual 1992, DOE/EIA-348(90). Washington, DC, January 1994.

Emissions of Greenhouse Guses in the United States 19871992, DOE/ETA-0573. Washington, DC, October 1994. and prior issue.

Energy Policy Act Transportation Rate Study, Azxilabilicy of Data and Studies, DOE/ETA-0571. Washington, DC, October 1993.

"Federal and Indian Coal Lands: A Growing Source of Energy and Revenue." Copl Production 1992, DOE/ELA0118(92). Washington, DC, October 1993, pp. 1-14.

Historical Monthly Energy Reoiew 1973-1992, DOE/EIA0035(73-92). Washington, DC, August 1994.

International Energy Annual 1992, DOE/EIA-0219(92). Washington, DC, January 1994.
Inventory of Potwer Plants in the Unifed Sfates 1992, DOE/EIA-0095(92). Washington, DC, October 1993.

"Large U.S. Coal Mines" Canl Production 1986, DOE/ELA-0118(86). Washington, DC, January 1988, PP. 4-9.

Monthly Energy Review, DOE/ELA-0035(94/06). Washington, DC, June 1994.

Profiles of Foreign Dinect Investment in U.S. Energy 1992, DOE/ELA-0466(92). Washington, DC, May 1994.

"Lignite A Low Rank Coal Gains Status." Conl Distribution January-December 1986, DOE/EIA0125(4/Q). Washington, DC, April 1987, pP. 3-7.

"Pennsylvania Anthracite: An Overview of the 'Hard Coal' Industry." Coal Distribution January-September 1986, DOE/ELA-0125(B6/3Q). Washington, DC, January 1987, PP. 3-7.

Quarterly CanI Repori October-December 1993, DOE/ELA-0121 (93/4Q). Washington, DC, May 1994 and prior issues.

State Coel Profiles, DOE/EIA-0576. Washingtion, DC, January 1994.

State Energy Data Report 1992: Consumption Estimites, DOE/ELA-0214(92). Washington, DC, June 1994.

"The Appalachian Coal Basin: An Overview of Coal Deposits and Production." Coal Production 1987. DOE/EIA-118(87). Washington, DC, December 1988, Pp. $1-6$.

The Changing Siructure of the Electric Power Indusiry 1970-1991, DOE/EIA-0562. Washington, DC, March 1993.

The Changing Structure of the U.S. Coal Industry: An Updaie, DOE/EIA-0513(93). Washington, DC, July 1993.

"The Interior Coal Region of the United States: Overview and Summary." Conl Production 1988, DOE/EIA-I18(B8). Washington, DC, November 1989, PP. 1-8.

"The Powder River Basin." Coal Praduction 1985, DOE/EIA-0t18(85). Washington, DC, November 1986, PF. 4-8.

The U.S. Coal htitustry, 1970-1990: Two Decades of Change, DOE/EIA-0559. Washington, DC, November 1992. 
Trends in Contract Caal Transpontation 1987-1987, DOE/ELA-0549. Washington, DC, September 1991.

"Update on U.S. Coalbed Methane Production," Natural Gas Monthly Octaber 1990, DOE/EIA-0130(90/10). Washington, DC, Deccember 1990, pp. 1-15.

"US. Coal Production in the 1980's: An Overview." Coal Production 1989, DOE/ELA-118(89). Washington, DC November 1990, pp. 1-10.

U.S. Coal Reseroes: An Ltpdabe by Heat and Sulfur Content, DOE/ELA-0529(92). Washington, DC, February 1993.

"U.S. Coalbed Methane Production," Natzond Gas Monthly Jattuary 1994, DOE/ELA-0130(94/01). Washington, DC, January 1994, PP. 1-I1.

Weakly Coni Production, DOE/ELA-0218 (various issues). Washington, DC.

"Wyoming Coalt An Overvtew." Canl Production 1991, DOE/BIA-0I18(91). Washington, DC, October 1992, pp. 1-11.

The National Coal Council (A Federal advisory committee to the Secretary of Energy-)

Clean Can Techuology for Stustainable Dextopment. Arlington, V $A_{r}$ February 1994.

Improwing Caal's Image; $A$ National Entergy Stratery Impletative. Arlington, VA, January 1992.

Industrial Use of Caal and Clean Coal Technology. Arlington, CA, June 1990 .

The Export of U.S. Coal and Coal Tecinologies. Arlingion, VA, November 1993.

The Long-Range Role of Coal in the Future Energy Stratey of the Unifed Siates. Arlington, VA, Jure 1990.

The Near Term Role for Call in the Future Energy Strategy of the United Siates. Arifingtor, VA, January 1992.

The Use of Conl $i n$ the Industrial, Commercial, Residentinl, and Transporfation Sectors. Arlington, VA, December 1985.

\section{U.S. Department of the Army}

U.S. Army Corps of Engineers, Navigation Data Center
The U.S. Waterway System-Facts. Alexandria, VA. January 1994.

\section{U.S. Department of the Interior}

Energy Resources on Federally Adninistered Lands. Washington, DC, 1981.

\section{Bureau of ulnes:}

A Cost Compratison of Selected Conl Mines From Australia, Canoda, Colombia, South Africa, and the United States. Special Publication. Washington, DC, 1993.

A Dictiontary of Mining, Mineral, and Relaied Tems. Washington, DC, 1968.

Bureat of Mirtes Research 93. Washington, DC, 1993.

Causes of Coal Miner Absenfeeism. Information Circular 9161. Pittsburgh, PA, 1987.

Cheracterization of the 1986 Coal Mining Workforce. Information Circular 9192. Minneapolis, MN, 1988.

Conl Carbonization in the United States, 1900-62. Information Circular 8251. Washington, DC, 1965.

Demonstrated Reserde Base of U.S. Coris wibh Potential for Use in Mosuffacture of Metallurgical Canl. Information Circular B805. Washingtom, DC, 1979.

Forms of Sulfur in U.S. Conls. Information Circular $\$ 301$. Washington, DC, 1966.

Historical Summary of Coal-Mine Explosions in the United States, 1810-1958. Bulletin 586. Washington, DC, 1960.

Human Factors Contributing to Groundfall Accidents in Underground Mines: Workers' Vieus. Information Circular 9127. Pittsburgh, PA, 1987.

Mine Health and Safety Research. Washington, DC, 1993.

Mineral Facts and Problens. "Anthracite" and "Bituminous Coal and Lignite." Washington, DC, 1960, 1965,1970 and 1975.

Minevals Yearbook. "Bituminous Coal and Lignite," "Coke and Coal Chemicals," and "Pennsylvania Anthracite." Washington, DC, 1932-1976. 
Onerview of Mine Substidence listurance Programs in the United States. Information Circular 9362. Pittsburgh, PA, 1993.

Production of Mitteral Fuels and Hydropower in the United Siales Since 1800. Information Circular 8155 . Washington, DC, 1963.

The History and Future of Longwall Mining in the United Siates. Information Circular 9316. Pittsburgh, PA 1992.

The U.S. Foundry Coke Industry. Information Circular 8759. Washington, DC, 1977.

\section{Geologica: Survey:}

Coal Map of North America. Denver, CO, 1988.

Cool Resources of the United States, January 1, 1974. Bulletin 1412. Washington, DC, 1975.

\section{Minerals Maragement Service:}

Mineral Revenues 1993: Report on Receipis from Federal and indian Leases and prior issues. Washington, DC.

\section{U.S. Department of Labor}

Bureau of Labor Statistics. Employment, Hours, and Earnings, United States, 1909-90, Volume I. Bulletin 2370 Washington, DC, March 1991.

Bureau of Labor Statistics. Employment, Hours, and Eornings, Linited States, 1981-93. Bulletin 2429. Washington, DC, August 1993.

Bureau of Labor Statistics. Technological Change and Its Impact on Labor in Four Industries. Chapter 1, Coal Mining. Bulletin 2409. Washington, DC, October 1992
Mine Safety and Health Administration. Injury Experientce ón Conl Mining 1993 and prior issues. Denver, $C O$.

Mine Safety and Health Administration. Summory of Selected injury Experience and Worktine for the Mining industry in the United States, 1931-77. Information Report 1132. Denver, CO, 1984.

\section{U.S. Department of Transportation}

\section{Maritime Administratlon}

Office of Port and Intermodal Development. Existing and Potentiel U.S. Conl Export Looding Terminals. Washington, DC, Januacy 1992.

\section{U.S. Environmental Protection Agency}

Office of Air and Radiation. The Piain Engiish Guide to the Clean Air Act: Air and Radiation (ANR-443), BPA 400K-93-001. Washington, DC, April 1993.

Office of Air Quality Planning and Standards. National Air Polluiant Emission Trends: 1900-1992, EPA-454/R-93032. Research Triangle Park, NC, October 1993.

\section{U.S. Internatlonal Trade Commission}

Meialturgical Coke: Baseline Analysis of the U.S. Finustry and Imports. Publication 2745. Washington, DC, March 1994. 


\section{Sources of Information on Coal}

Many publications about coal and coal-related subjects are sold by the Superintendent of Documents, U.S. Government Printing Office, Washington, DC, Telephone: (202) 783-3238. Reference copies of many of these publications are available to the public in Federal Depository libraries located nationwide. A list of depository libraries is available free upon request from: Federal Depository Library Program, Office of the Public Printer, Washington, DC 20401.

Energy Research Abstracts (ERA) provides abstracting and indexing coverage of all scientific and technical reports, fournal articles, conference papers and proceedings, books, patents, theses, and monographs originated by the U.S. Depertment of Energy, its laboratories, energy center and contractors. ERA also covers other energy information prepared in report form by Federal and State government organizations, foreign governments, and domestic and foreign universities and research organizations. ERA coverage of nonreport

\section{U.S. Department Of Energy}

National Energy Infomation Center, EI-231

ForrestaI Building

Washington, DC 20585

(202) 586-8800

Public Inquires

Office of Public Affairs

Forrestal Building

Washington, DC 20585

(202) 586-5575

Office of Scientific and Tethrical trformation

P.O.Box 62

Oak Ridge, TN 37831

(615) 576-130I

Morgentown Energy Technoiogy Center

P.O.Box 880

Morgantown, WV 26507

(304) $285-4764$

Pittsburgh Energy Technology Center

P.O. Box 10940

Pittsburgh, PA 15236

(412) $892-6029$ literature is limited to that generated by Department of Energy activity. DOE and DOE contractors who have OSTI deposit accounts can obtain ERA from the Office of Scientific and Technical Information, P.O. Box 62, Oak Ridge, TN 37831, Attention: Information Services. For hurther information, call (615) 576-1155. ERA is available to the public on a subscription basis from the Superintendent of Documents, U.S. Government Printing Office, Washington, DC, 20402.

Coel Abstracts provtdes comprehensive world-wide coverage of books, joumals, report, dissertations, and conference proceedings in the field of coal science and technology from the evaluation of deposits to the ultimate uses of coal as an energy source and raw material, including environmental effects. Coal Abstracts is published by the Intemational Energy Agency (IEA), Coal Research, Gemini House, 10-18 Putney Hill, London SW15 6AA, United Kingdom.

\section{Other Sources}

American Boller Manufacturers Association 950 North Glebe Road, Suite 160

Arlington, VA 22203

(703) $522-7350$

American Coal Ash Association, Inc., 2760 Eisenhower Ave, Suit 304

Alexandriz, VA 22314

(703) $317-2400$

American Coal Foundation

918 16th Street, N.W.

Washington, DC 20006

(202) $466-8630$

American Coke \& Coal Chemicals Institute 1225 23rd Street, N.W.

Washington, DC 20037

(202) 452-1140

Bureau of Land Management

U.S. Department of the Interior

184, \& C Streets, NW.

Washington, DC 20240

(202) 208-3435 
Bureau of Mines

U.S. Department of the Interior

Pittsburgh Research Center

Cochran Mill Rd.

P.O. Box 18070

Pittsburgh, PA 15236

(412) $892-6602$

Coal \& Slurry Technology Association 1156 15th Street, N.W.

Washington, DC 20005

(202) 296-1133

Geological Survey

U.S. Department of the Interior

The National Center

12201 Sunrise Valley Drive

Reston, VA 22092

(703) 648-4000

Mime Satety and Health Administration

U.S. Department of Labor

40154 Wilson Blud.

Arlington, VA 22203

(703) 235-1456

Minerals Information Office

U.S. Department of the Interior

18th \& C Streets, N.W.

Washington, DC 20240

(202) 208-5520
Minerals Management Service

U.S. Department of the Interior

18th \& C Streets, N.W.

Washington, DC 20240

(202) 208-3983

National Coal Association

1130 17th Street, N.W.

Washington, DC 20036

(202) 463-2625

National Technical Information Service

U.S. Department of Commerce

5285 Port Royal Rd.

Springfield, VA 22161

(703) 487-4650; (800) 553-NTIS

Office of Surface Mining

U.S. Department of the Interior

1951 Constitution Ave, NW

Washington, DC 20240

(202) 208-2553

U.S. Environumental Protection Agency

$401 \mathrm{M}$ Street S.W.

Washington, DC 20460

(202) 260-2080 ot 7751

In coal-producing States: State Mine Agencies and Geological Surveys. 